UNIVERSIDADE DE SÃO PAULO

ESCOLA DE ARTES, CIÊNCIAS E HUMANIDADES

PROGRAMA DE PÓS-GRADUAÇÃO EM ESTUDOS CULTURAIS

NICOLE PALUCCI MARZIALE

Experimentações Institucionais no Museu de Arte Contemporânea de Barcelona (MACBA)

São Paulo

2018 
NICOLE PALUCCI MARZIALE

\title{
Experimentações Institucionais no Museu de Arte Contemporânea de Barcelona
} (MACBA)

\author{
Versão Corrigida
}

Dissertação apresentada à Escola de Artes, Ciências e Humanidades da Universidade de São Paulo para obtenção do título de Mestre em Filosofia pelo Programa de Pósgraduação em Estudos Culturais

Versão corrigida contendo as alterações solicitadas pela comissão julgadora em 27 de setembro de 2018 . A versão original encontra-se em acervo reservado na Biblioteca da EACH/USP e na Biblioteca Digital de Teses e Dissertações da USP (BDTD), de acordo com a Resolução CoPGr 6018, de 13 de outubro de 2011

Área de Concentração: Estudos Culturais

Orientadora: Profa. Dra. Dária Gorete Jaremtchuk 
Autorizo a reprodução e divulgação total ou parcial deste trabalho, por qualquer meio convencional ou eletrônico, para fins de estudo e pesquisa, desde que citada a fonte.

Marziale, Nicole Palucci

Experimentações institucionais no Museu de Arte

Contemporânea de Barcelona (MACBA) / Nicole Palucci Marziale :

orientadora, Dária Gorete Jaremtchuk. - 2018

$212 \mathrm{p}$.

Dissertação (Mestrado em Filosofia) - Programa de PósGraduação em Estudos Culturais, Escola de Artes, Ciências e Humanidades, Universidade de São Paulo, São Paulo.

Versão corrigida

1. Museus de arte - Espanha. 2. Instituições culturais. 3. Experimentação. 4. Museu de Arte Contemporânea de Barcelona. 5. Público. 6. Participação. I. Jaremtchuk, Dária Gorete, orient. II. Título.

CDD 22.ed.- 708.9663 
Nome: MARZIALE, Nicole Palucci.

Título: Experimentações Institucionais no Museu de Arte Contemporânea de Barcelona (MACBA).

Dissertação apresentada à Escola de Artes, Ciências e Humanidades da Universidade de São Paulo para obtenção do título de Mestre em Filosofia pelo Programa de Pósgraduação em Estudos Culturais

Aprovado em: 27/09/18

\section{Banca Examinadora}

Prof. Dr. Emerson Dionisio Gomes de Oliveira

Instituição: Universidade de Brasília. Instituto de Artes

Profa. Dra. Maria de Fátima Morethy Couto

Instituição: Universidade de Campinas. Instituto de Artes

Prof. Dr. José Carlos Garcia Durand

Instituição: Universidade de São Paulo. Escola de Artes, Ciências e Humanidades. 


\section{Agradecimentos}

Agradeço à professora Dária Jaremtchuk, pela orientação. Aos meus pais, meu irmão e ao Francisco, pelo apoio incondicional. À Coordenação de Aperfeiçoamento de Pessoal de Nível Superior (CAPES), pela concessão de bolsa de estudo. 


\section{RESUMO}

MARZIALE, Nicole Palucci. Experimentações Institucionais no Museu de Arte Contemporânea de Barcelona (MACBA). 2018. 212 p. Dissertação (Mestrado em Filosofia) - Escola de Artes, Ciências e Humanidades, Universidade de São Paulo, São Paulo, 2018. Versão Corrigida.

Esta dissertação parte da observação de práticas institucionais experimentais que se concentraram principalmente na Europa, a partir dos anos noventa. Tais experimentações buscaram reestruturações institucionais, prezando pelo engajamento do público em suas atividades, além de fazer frente a modelos pautados no entretenimento e no espetáculo, de modo a contrariar tais premissas, e tendo como referência exposições experimentais paradigmáticas realizadas a partir dos anos sessenta, bem como práticas da Crítica Institucional do mesmo período. No entanto, várias dessas instituições experimentais enfrentaram problemas para manter suas atividades, com cortes de financiamento e até mesmo, em alguns casos, o encerramento de suas atividades. Diante disso, tomamos como objeto de estudo o caso do Museu de Arte Contemporânea de Barcelona (MACBA), reconhecendo, em sua história, um período notavelmente marcado por propostas experimentais, sob a direção de Manuel Borja-Villel, a fim de rastrear a continuidade, ou não, de propostas nesse sentido nas gestões seguintes, de Bartomeu Marí (2008-2015) e Ferran Barenblitt (desde 2015), bem como possíveis dificuldades enfrentadas para sua manutenção e desenvolvimento. Avalia-se, por um lado, a possibilidade de que figuras específicas de liderança, no caso os diretores das instituições, são cruciais para a implementação e sustentação das propostas diante dos diversos atores que coexistem dentro das estruturas institucionais, como membros de Conselhos e fundações. Por outro lado, considera-se também o papel desses órgãos na tomada de decisões dentro da instituição, diante dos quais o diretor pode ter sua autonomia limitada.

Palavras-chave: Experimentações Institucionais. Instituições de Arte. Museus de Arte. MACBA. 


\begin{abstract}
MARZIALE, Nicole Palucci. Institutional Experimentations in the Barcelona Museum of Contemporary Art (MACBA). 2018. 212 p. Dissertation (Master of Philosophy) - School of Arts, Sciences and Humanities, University of São Paulo, São Paulo, 2018. Corrected Version.
\end{abstract}

This dissertation starts with the observation of experimental institutional practices that were concentrated mostly in Europe, since the nineties. These experimentations seeked intitutional restructuring, caring for the participation of the visitors, and also sought to oppose to the models based on entertainment and spetacle, in order to go against those premises, and having, as a reference, paradigmatic experimental exhibitions made since the sixties, as well as Institutional Critique practices of the same period. However, many of these experimental institutions faced problems in mantaining their activities, with cutbacks in financing and even, in some, cases, the closedown of their activities. In face of this scenario, we took as a case study the Barcelona Museum of Contemporary Art, recognizing, in its history, a period notably marked by experimental propositions, under the direction of Manuel Borja-Villel, in order to trace the continuity, or not, of these kinds of propositions in the following directorships, from Bartomeu Marí (2008-2015) and Ferran Barenblitt (since 2015), as well as possible dificulties met in their mantainance ad developing. Furthermore, it is considered, on the onde hand, the possibility that specific leadership figures are crucial to the implementation and support of the experimental propositions before the many actors that coexist inside the institutional structures, like Board members and foundations. On the other hand, it is reckoned the role of these figures in making decisions inside the institution, in the face of which the director may have its autonomy limited.

Keywords: Institutional Experimentations. Art Institutions. Art Museums. MACBA. 


\section{Sumário}

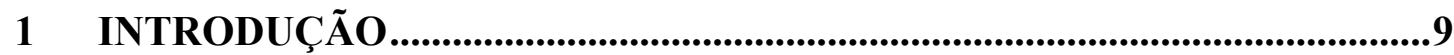

2 EXPERIMENTAÇÕES INSTITUCIONAIS A PARTIR DO FINAL DOS

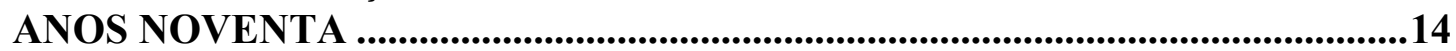

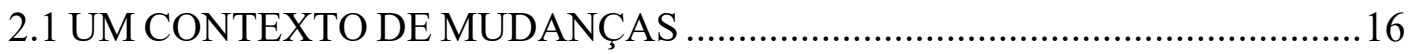

3 ALGUNS CASOS DE EXPERIMENTAÇÕES INSTITUCIONAIS .............34

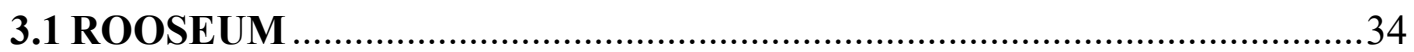

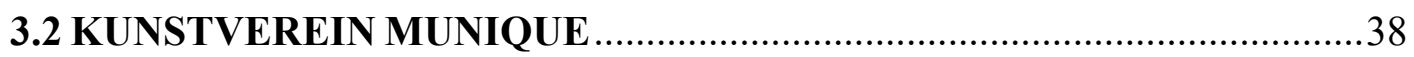

3.3 BASIS VOOR ACTUELE KUNST (BAK),.............................................4

3.4 PLATAFORM GARANTI ................................................................. 43

3.5 PRINCIPAIS CARACTERÍSTICAS DOS PROGRAMAS OBSERVADOS

4 EXPERIMENTAÇÕES INSTITUCIONAIS NO MUSEU DE ARTE CONTEMPORÂNEA DE BARCELONA (MACBA) ............................................49

4.1 A GESTÃO DE DANIEL GIRALT-MIRACLE (1988-1994) ............................53

4.2 A GESTÃO DE MIQUEL MOLINS (1995-1998) ……………………….......54

4.3 A GESTÃO DE MANUEL BORJA-VILLEL (1998-2008)................................60

4.3.1 Mudanças de Borja-Villel com relação à gestão anterior............................63 63

4.3.3 A relação entre o público e a instituição o....................................................... 78

4.3.4 Atividades realizadas durante a gestão de Borja-Villel............................... 78

4.3.5 Experimentações em uma Nova Institucionalidade..................................... 79

4.3.6 O elemento pedagógico na gestão de Borja-Villel ........................................88

4.3.7 A recepção da gestão de Borja-Villel ...........................................................88

4.3.8 Sobre a gestão de Borja-Villel ........................................................................99

4.4 A GESTÃO DE BARTOMEU MARÍ (2008-2015) ………………………......92

4.4.1 Atividades desenvolvidas a partir da gestão de Bartomeu Marí................97

4.4.2 A Besta e o Soberano ....................................................................................... 123

4.4.3 A recepção da gestão de Bartomeu Marí ................................................126

4.4.4 Sobre a gestão de Bartomeu Marí........................................................128

4.5 A GESTÃO DE FERRAN BARENBLIT .....................................................129

4.5.1 Programa a partir de 2016...........................................................................134

4.5.2 A recepção da gestão Ferran Barenblit .......................................................150

4.5.3 Sobre a gestão Ferran Barenblit ...............................................................150

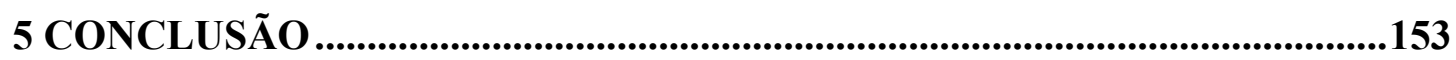

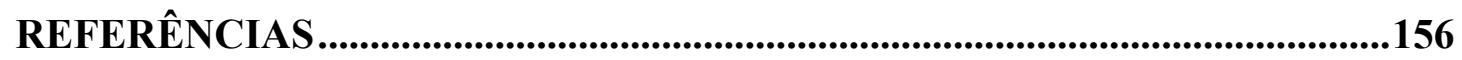


ANEXO A - OUTRAS ATIVIDADES REALIZADAS NA GESTÃO BORJAVILLEL

ANEXO B-ATIVIDADES REALIZADAS DURANTE A GESTÃO BARTOMEU

MARÍ: O DEBATE POLIITICO NO MUSEU.

ANEXO C - ATIVIDADES REALIZADAS DURANTE A GESTÃO BARTOMEU

MARÍ: A PROPOSIÇÃ̃O DE NARRATIVAS CONTRA-HEGEMÔNICAS DA

HISTÓRIA DA ARTE.

ANEXO D - MODIFICAÇÃO DA NARRATIVA SOBRE A HISTÓRIA DA ARTE NA GESTÃO BARTOMEU MARÍ: SEMINÁRIOS, CONFERÊNCIAS, CURSOS E MESAS REDONDAS

ANEXO E - ATIVIDADES ORGANIZADAS PELO PEI DURANTE A GESTÃO BARTOMEU MARÍ 193

ANEXO F - GESTÃO BARTOMEU MARÍ: EXPOSIÇÕES MONOGRÁFICAS

ANEXO G - GESTÃO FERRAN BARENBLIT: EXPOSIÇÕES

MONOGRÁFICAS.

ANEXO H - DEBATE POLÍTICO NA GESTÃO FERRAN BARENBLIT:

EXPOSIÇÕES, SEMINÁRIOS, CONFERÊNCIAS, CURSOS E MESAS REDONDAS.

ANEXO I - PROJETO MUSEO CERRADO: PARTICIPANTES .208

ANEXO J - ATIVIDADES REALIZADAS PELO PEI DURANETE A GESTÃO FERRAN BARENBLIT. 


\section{INTRODUÇÃO}

Este trabalho parte da observação de propostas de diretores de instituições de arte contemporânea, a partir dos anos noventa, principalmente no âmbito europeu, para promover programas experimentais dentro de seus contextos institucionais. Tais propostas surgem em meio à crescente influência do capitalismo globalizado e corporativo sobre a dinâmica das instituições de arte, e objetivam reafirmar o caráter crítico e reflexivo desses espaços, que se veem ameaçados diante da disseminação, no âmbito cultural, de imperativos econômicos e da primazia pelo entretenimento por si só. Ainda, trata-se de uma reação de instituições de crítica específicas, ou seja, instituições que internalizaram as propostas de duas gerações de artistas engajados com a Crítica Institucional, e que tomaram como referência exposições paradigmáticas organizadas por curadores independentes, a partir do final dos anos sessenta.

Cabe notar que há termos diversos cunhados para referirmo-nos a esse tipo de propostas, de modo que não há um consenso acerca de uma nomenclatura. Desse modo, temos o uso do termo Novo Institucionalismo pelo crítico e curador Jonas Ekeberg, a partir da primeira edição da série de publicações Verksted, publicada pelo Office for Contemporary Art in Norway (Oslo, Noruega); já o ex-diretor de Programas Públicos do Museu de Arte Contemporânea de Barcelona (MACBA), Jorge Ribalta, refere-se a experimentos em uma Nova Institucionalidade, enquanto Charles Esche, atual diretor do Van Abbemuseum, trata de um Institucionalismo Experimental. No presente trabalho, por sua vez, tratamos de experimentações institucionais. Ao utilizarmos esse termo, fazemos referência a museus e centros de arte que buscaram promover modelos críticos e autorreflexivos de instituições, implicar a participação dos visitantes na realização de seus processos, e não apenas "educá-los", responder às necessidades dos membros de suas comunidades e suscitar o debate de questões políticas importantes tanto local como globalmente. Os programas dessas instituições costumam abranger atividades diversas, como debates, seminários, projetos colaborativos, oficinas, publicações, residências de pesquisa, entre outras, de modo que as exposições não atuam como protagonistas, mas sim fazem parte de um programa integrado e multifacetado.

Para melhor ilustrar esse tipo de propostas, trazemos exemplos de gestões específicas em instituições diversas, tais como: a gestão de Charles Esche no Rooseum, na cidade sueca de Malmö, entre 2000 e 2004; a direção da Kunstverein de Munique pela curadora Maria Lind, de 2002 a 2004; a fundação e direção do Basis voor Actuele Kunst (BAK), em 
2003, por Maria Hlavajova; a atuação de Vasif Kortum como diretor da Platform Garanti, em Istambul.

No contexto de experiências como essas, emerge, no entanto, um problema: muitas instituições passaram a sofrer cortes orçamentários, mudanças de direcionamento político e até o encerramento de suas atividades. Diante disso, surge o interesse em investigar a respeito dos desdobramentos de propostas desse tipo passado o período inicial de sua implementação, a fim de verificar a possibilidade de sua continuidade, ou não, no cenário atual. Especula-se também a respeito da importância de figuras específicas no comando das instituições, capazes de mediar possíveis conflitos e posicionar-se frente às figuras que integram as estruturas institucionais, como patrocinadores, membros de Conselhos e fundações, entre outros. Por outro lado, indaga-se a respeito da autonomia dos diretores das instituições de arte para efetivar suas propostas, diante dos interesses dessas outras estruturas de poder que permeiam esses espaços.

Para tanto, tomamos como objeto principal de nosso estudo o caso de uma instituição específica, o Museu de Arte Contemporânea de Barcelona (MACBA). A escolha por essa instituição foi feita a partir da observação dos programas realizados na gestão de Manuel Borja-Villel como diretor, entre os anos de 1998 e 2008, durante a qual foram implementadas radicais e importantes mudanças dentro do Museu, que desde sua inauguração, em 1995, ainda não contava com um projeto de museu definido. Assim, a partir de sua gestão, foram estabelecidas diretrizes que proporcionaram o estabelecimento de um discurso político sólido e um programa crítico de atividades. Nesse sentido, foram desenvolvidos o que Jorge Ribalta, ex-diretor de Programas Públicos da instituição, denominou como experimentos em uma Nova Institucionalidade: atividades que buscaram aproximar o Museu dos visitantes, da comunidade da cidade e de movimentos sociais, mediante o desenvolvimento de projetos colaborativos. Buscou-se traçar um contexto do MACBA desde a sua concepção e inauguração, a fim de verificarmos os objetivos e as propostas que as circundam, passando pelas gestões de seus primeiros diretores e a exposição do programa realizado para o Museu durante a gestão de Manuel Borja-Villel. A partir daí, são analisadas as gestões dos diretores que o sucederam: Bartomeu Marí (2008-2015) e Ferran Barenblit (desde 2015), a fim de verificarmos a respeito da possibilidade de ter-se constituído uma "cultura institucional" no que tange à proposição de experimentações institucionais dentro do Museu, bem como possíveis dificuldades enfrentadas para seu desenvolvimento. Avaliamos, por um lado, a possibilidade de que a sustentação de proposições radicais nesse sentido esteja, em grande 
parte, ancorada às figuras de diretores específicos, como seria o caso de Borja-Villel, capazes de defender seu discurso diante de possíveis desacordos entre os membros decisores das instituições. Por outro lado, cabe questionarmos se as estruturas decisórias e de poder internas à instituição não acabariam por determinar e possivelmente cercear a autonomia dos diretores em casos de eventuais conflitos de interesses.

Traçado o contexto inicial do qual parte este trabalho, verifica-se que, no segundo capítulo, foram apresentados os principais aspectos das instituições que propuseram as experimentações institucionais em questão, além de abordadas as considerações iniciais sobre o tema. Em seguida, é ilustrado o contexto que propicia o desenvolvimento das experimentações institucionais em questão: as graduais mudanças nos modelos tradicionais de museu, como reação a novas manifestações artísticas, e o surgimentos de instituições mais abertas e participativas, como o "pós-museu", além dos conceitos de centros de arte e Museologia Radical. Também são tomadas como referência as ações de Crítica Institucional realizadas por artistas a partir dos anos sessenta, bem como o desenvolvimento das Instituições de Crítica. Outro elemento levado em consideração diz respeito às mudanças quanto às funções atribuídas ao curador no contexto institucional, que passa a atuar como “autor de exposições", bem como desempenhar tarefas administrativas, editoriais e de gestão. É abordado também o processo de envolvimento corporativo no âmbito das artes e da cultura, e como as instituições experimentais em questão surgem para fazer frente aos imperativos da lógica de mercado aplicada a esse contexto.

No terceiro capítulo, trazemos alguns casos de instituições em que foram realizadas, ao menos por certos períodos, experimentações institucionais, de modo que abordamos recortes temporais específicos, marcados pelas gestões de determinados diretores, a fim de observar suas diferentes propostas. São consideradas: a gestão de Charles Esche no Rooseum, na cidade sueca de Malmö, entre 2000 e 2004; a Kunstverein de Munique, sob a direção de Maria Lind, de 2002 a 2004; a fundação e direção do Basis voor Actuele Kunst (BAK), em 2003, por Maria Hlavajova; a atuação de Vasif Kortum como diretor da Platform Garanti, em Istambul, entre 2001 e 2007.

No quarto capítulo, é abordado o caso do MACBA. Começamos por entender o processo de formação do Museu, desde sua idealização inicial, pelo crítico de arte Alexandre Cirici Pellicer, até sua inauguração, em novembro de 1995. Nesse contexto, esclarecemos a respeito de suas estruturas institucionais, caracterizadas pela presença do Consórcio MACBA, bem como as dificuldades enfrentadas pelos primeiros diretores do Museu diante da 
morosidade dos membros do Consórcio em chegar a um consenso quanto ao projeto a ser estabelecido para o Museu. Em seguida, observamos, a partir da gestão de Manuel BorjaVillel, a implementação de um projeto sólido para o MACBA, tanto no que tange ao direcionamento a ser seguido pela Coleção, como quanto a seu programa de exposições e atividades diversas, sendo que se destaca o envolvimento do Museu no contexto político da época, atuando junto a movimentos sociais e coletivos de arte, de maneira colaborativa, bem como a intenção de aumentar a participação popular no âmbito institucional. Desse modo, são analisados tanto o discurso e propostas de Borja-Villel para sua gestão, como as atividades realizadas no período que se estende de 1998 a 2008. Prosseguimos então com as análises das gestões posteriores à de Borja-Villel: as de Bartomeu Marí, de 2008 a 2015 e Ferran Barenblit, atual diretor do MACBA, entre 2016 e 2017. Vale assinalar que o mapeamento das atividades foi feito de forma resumida dentro dos itens referentes à gestão de cada diretor, estando elencadas na íntegra nos anexos ao final do trabalho.

No capítulo final, tentamos encontrar respostas para as questões levantadas ao longo do trabalho a partir do estudo de caso das atividades desenvolvidas no MACBA, de modo que se indaga: houve uma continuidade na proposição de experimentações institucionais ao longo das gestões de Bartomeu Marí e Ferran Barenblit? A implementação de experimentações institucionais estaria amparada, em grande parte, na figura de certos diretores? Por outro lado, as estruturas decisórias internas da instituição podem acabar por limitar sua autonomia? As experimentações institucionais realizadas nas décadas de noventa/dois mil ainda têm ressonância na atualidade?

Quanto às fontes de pesquisa consultadas, foram utilizados elementos referentes à pesquisa bibliográfica, tais como escritos de curadores e diretores a respeito das atividades realizadas nas instituições abordadas e entrevistas por eles concedidas a jornais e revistas especializadas, além de livros e catálogos institucionais. Também foram consultados recursos que dizem respeito à pesquisa documental, graças à realização de uma residência de pesquisa no Centro de Estudos e Documentação (CEDOC) do MACBA, durante o mês de novembro de 2017, por meio do Programa de Apoio à Investigação do Museu. No CEDOC, foi possível consultar registros de atividades do Museu, como folders e material audiovisual. Vale destacar que grande parte dessa documentação está também disponível online, graças aos esforços do Centro de Documentação. A análise de resultados foi realizada a partir da verificação quanto a se as atividades realizadas ao longo das diferentes gestões do MACBA atendiam aos elementos que consideramos característicos de experimentações institucionais, e 
se foi possível a criação de uma cultura institucional nesse sentido, a partir da gestão de Borja-Villel.

Por fim, vale atentarmo-nos para o fato de que as fontes consultadas são essencialmente oficiais, tendo sido escritas pelos próprios diretores, ou oriundas das próprias instituições, de modo que não se pretende entendê-las como verdades absolutas, mas sim espécies de "representações de si mesmas". Sendo assim, deve-se esclarecer que não houve, ao longo do trabalho, uma investigação acerca da recepção do público com relação às atividades realizadas, mas sim foram consideradas as intenções de cada diretor, evidenciadas por meio de seus discursos e das propostas de seus programas. 


\section{EXPERIMENTAÇÕES INSTITUCIONAIS A PARTIR DO FINAL DOS ANOS NOVENTA}

Este capítulo pretende, em primeiro lugar, apresentar o tema que atua como ponto de partida para esta dissertação: a realização, a partir do final dos anos noventa, de propostas por parte de curadores e diretores de instituições de arte contemporânea, de diferentes portes e em diferentes localidades, para promover experimentações e alterações quanto as suas estruturas institucionais, visando o desenvolvimento de espaços críticos e auto-reflexivos, em constante diálogo com seus públicos e as comunidades de seu entorno.

Pretendemos, de início, evidenciar o contexto em que surgem tais iniciativas, tanto do ponto de vista museológico, como econômico e cultural. Nosso percurso abarca, em primeiro lugar, a gradual transformação das estruturas museológicas tradicionais, herdadas do modelo de museu moderno europeu a partir do século XVIII, em direção à reconfiguração quanto a sua rigidez e a possibilidade de emergência de novos modelos. Em seguida, procuramos entender a conjuntura econômica que motiva o surgimento das instituições experimentais, o que tem relação com a intensificação do processo de envolvimento corporativo no campo cultural. Ademais, notamos como a figura do curador passa a ganhar um papel de destaque no contexto das instituições de arte, sendo que muitas dessas proeminentes figuras passam a atuar, posteriormente, como diretores de instituições de arte. Também é explicitada a importância da tradição da Crítica Institucional como referência para as práticas aqui estudadas, além de casos paradigmáticos de exposições experimentais.

Sendo assim, entre o final dos anos noventa e o início dos anos dois mil, são observadas, de acordo com Lucie Kolb e Gabriel Flückiger (2013), uma série de práticas curatoriais, arte educacionais e educativas por parte de instituições de arte contemporânea, que se esforçaram por reorganizar as estruturas dessas instituições, além de definir formas alternativas de programação. Para os projetos iniciados nesse contexto, a prática institucional não estava limitada a programas expositivos tradicionais, como exposições individuais ou temáticas, de modo que essas eram concebidas como projetos sociais, e operados junto a seminários, programas de exibição de filmes, programas de rádio e televisão, bibliotecas e livrarias integradas, grupos de leitura, exibições online, residências, entre outras atividades (KOLB; FLÜCKIGER, 2013). Ainda, os usos desses formatos permaneciam adaptáveis e abertos a mudança, de modo que produção, apresentação e recepção/crítica não eram atividades sucessivas e separadas, e sim aconteciam simultaneamente, frequentemente intersectando-se. Nessas empreitadas, exposições individuais poderiam durar um ano e exibir apenas um 
trabalho de cada vez. Nesse contexto, a instituição de arte funcionava como um espaço de produção, pesquisa e debate, em que aos visitantes eram atribuídos um papel ativo (KOLB; FLÜCKIGER, 2013).

Em 2003, o curador Jonas Ekeberg introduz, na primeira edição da série de publicações Verksted, publicada pelo Office for Contemporary Art in Norway (Oslo, Noruega), o termo Novo Institucionalismo, a partir da observação de projetos por parte de instituições como o Rooseum, em Malmö, Platform Garanti Contemporary Art Center em Istambul, a Kunsthalle de Bergen, a Kunstverein de Munique, bem como as Bienais de Johannesburgo e Moss, os quais ele cita na publicação. Ekeberg (2003) descreve um cenário em que as instituições de arte pareciam estar "recuperando o atraso" com relação à arte contemporânea, de modo que artistas, operando em um campo constantemente em expansão, passaram a requerer que as instituições fossem tão flexíveis e abertas como eles o eram. Como exemplo, ele se refere aos projetos orientados para a comunidade por parte do coletivo de arte New Meaning of Trondheim, da Noruega, para mostrar como grupos como esses não mais simplesmente esperavam ser convidados pelas instituições para apresentarem projetos em seu espaço por algumas semanas, e sim exigiam que a instituição com eles colaborasse a longo prazo, buscando maneiras de dividir tarefas e objetivos com os artistas. Por outro lado, também as instituições de arte pareciam, para Ekeberg (2003), esperar que os artistas estivessem prontos para colaborar em debates, oficinas e até mesmo criticamente em relação à posição da instituição anfitriã. Também Alex Farquharson (2006) destaca o papel chave desempenhado por grupos de artistas e coletivos interdisciplinares nos programas dessas novas instituições. Para ele, os coletivos de artistas, que caracteriza como políticos, ativistas, integrados em rede, colaborativos, auto-organizados e flexíveis, acabam por espelhar os novos desejos institucionais (FARQUHARSON, 2006).

Farquharson (2006) enfatiza que, se a ascensão da curadoria independente é um dos elementos principais dos anos noventa, a atenção passa a ser direcionada, a partir de dos anos dois mil, para os efeitos que esses curadores tiveram no comando de instituições. Desse modo, relevante número de curadores que em grande parte ficaram conhecidos ao atuar de maneira independente passaram a assumir o comando de museus e centros de arte. $\mathrm{O}$ autor também ressalta como uma das características definitivas dessas "novas instituições" é a de que as exposições nelas realizadas não mais se sobrepõem a outros tipos de atividades, de modo que elementos como produção, arquivos, pesquisa, publicações, residências e debates são igualmente enfatizados. Além disso, elas estariam profundamente interessadas em 
educação, em seu sentido mais amplo, em oposição aos modelos de educação hierarquizados presentes na maioria das instituições de arte, voltados para crianças e com o intuito de suplementar ou compensar pelas falhas nos sistemas educacionais governamentais (FARQUHARSON, 2006).

Vale notar que, além do uso do termo Novo Institucionalismo para tratar das práticas até aqui explicitadas, outros curadores e diretores de instituições criaram seus próprios termos, de modo que não há um consenso quanto a uma nomenclatura, e nem mesmo a noção de Novo Institucionalismo se pretende como criadora de um modelo conceitual, tendo sido levantado apenas de forma especulativa por Jonas Ekeberg, e adotado por alguns outros autores. Atentamos para a revisão que o artista e curador Jorge Ribalta faz das atividades desenvolvidas no MACBA durante a gestão de Manuel Borja-Villel como diretor, que aqui analisamos detalhadamente no capítulo 3, de modo que Ribalta as denomina Experimentações em uma Nova Institucionalidade. Também Charles Esche, atual diretor do Van Abbemuseum e ex-diretor do Rooseum, cuja gestão também é comentada, prefere utilizar o termo Institucionalismo Experimental. Ao longo do trabalho, referimo-nos a experimentações institucionais. Ainda que o termo "novo" seja por vezes utilizado para tratar das práticas institucionais aqui estudadas, vale enfatizar que essas não são inéditas. Desse modo, observamos, no decorrer no capítulo, tanto propostas curatoriais que precedem e servem como referência para aquelas aqui abordadas, bem como práticas de Crítica Institucional internalizadas por esses diretores, e aplicadas na construção de Instituições de Crítica.

\subsection{UM CONTEXTO DE MUDANÇAS}

Em primeiro lugar, atentamo-nos, retrospectivamente, à ascensão dos museus modernos, a partir do final do século XVIII e século XIX, na Europa, de modo a observar graduais mudanças em sua configuração, resultantes de um processo de mudanças na própria forma e nas práticas artísticas. De acordo com Liisa Uusitalo (2008), os museus, em seu sentido moderno, são originalmente um produto da Renascença, período durante o qual cresceu o interesse por artefatos produzidos pelas mãos humanas, bem como a sistematização e classificação científicas das obras de arte. Apenas após a Revolução Francesa, as coleções privadas, anteriormente pertencentes à aristocracia, foram abertas ao público, de modo que vários museus públicos proliferaram no século XIX na Europa (UUSITALO, 2008). De acordo com Hal Foster (2015): 
O cenário inicial para a exposição da pintura e da escultura modernas produzidas, como eram, tipicamente para o mercado - foi o espaço interior do século XIX, em geral a residência burguesa, e os primeiros museus dedicados a essa arte constituíram-se, muitas vezes, de salões de características semelhantes, remodelados para tal fim (FOSTER, 2015).

Eilean Hooper-Greenhill (2007) destaca como, em oposição aos anteriores gabinetes principescos e coleções reais, o museu modernista europeu do século XIX foi concebido para cumprir um papel público como parte do Estado-Nação, cuja maior parte consistia na educação de amplos setores da sociedade. Também desempenhava as funções de coleção e classificação de artefatos e espécimes, frequentemente advindos de territórios sob controle das nações colecionadoras, de modo a produzir uma visão de mundo enciclopédica, entendida a partir de uma perspectiva ocidental. Por meio da disposição cuidadosa de objetos, produzia declarações visuais que apresentavam aspectos de uma visão de mundo europeia (HOOPERGREENHILL, 2007). Para Tony Bennett (1995), a formação do museu não pode ser entendida adequadamente exceto se observada à luz de um conjunto mais geral de desenvolvimentos por meio dos quais a cultura, que passa a ser considerada útil para governar, foi moldada como um veículo para o exercício de novas formas de poder. O autor explica como ela passa a ser tratada, no que tange aos hábitos, maneiras, crenças e a moral das classes subordinadas, como um objeto do governo, e que necessitava transformação e regulação. Assim, a partir de meados do século XIX, as relações entre cultura e governo viriam a ser organizadas de maneira distintivamente moderna, por meio da concepção de que as obras, formas e instituições da alta cultura deveriam servir ao propósito de civilizar a população como um todo (BENNETT, 1995). Desse modo, acreditava-se que os museus poderiam aumentar o nível do gosto popular, além de evitar revoltas e conspirações (BENNETT, 1995).

Nesses museus de arte, o modo de exibição das obras era marcado pelo acúmulo de quadros nas paredes, de cima a baixo, e muito próximos entre si. A esse respeito, Brian O’Doherty (1986) explica que tal configuração se devia à visão de cada obra como uma entidade independente, totalmente isolada de suas vizinhas por uma pesada moldura, ao seu redor, e um completo sistema de perspectiva em seu interior, de modo que a primeira ajudaria a estabelecer os limites do quadro, enquanto a segunda garantiria a ilusão que convida, para dentro, os olhos do espectador. No entanto, aos poucos, algumas imagens passaram a “pressionar a moldura”, processo ocasionado, para O’Doherty (1986), principalmente pelo 
advento da fotografia: a noção das margens como uma firme convenção, trancando o tema dentro da figura, tornou-se frágil. Ainda de acordo com o autor, uma força ainda maior, o mito do "nivelamento" (flatness), eventualmente alterou a ideia da imagem, a forma como ela era pendurada e o espaço da galeria. Desse modo, o desenvolvimento de um espaço literal e "raso", em oposição ao espaço ilusório que continha formas "reais", passou a pressionar ainda mais os limites do quadro. Trata-se, pois, do prelúdio para a definição da pintura como um objeto autossuficiente, que caracteriza a obra de arte moderna (O'DOHERTY, 1986). De acordo com Foster (2015), “à medida que a arte moderna foi se tornando mais abstrata e autônoma", passa a "demandar um espaço que espelhasse essa sua condição destituída de um lar, um espaço que ficou conhecido como o 'cubo branco"” (FOSTER, 2015). O’Doherty (1986) descreve esse espaço, que deve permanecer isolado do mundo exterior, de modo que as janelas costumam ser vedadas; as paredes são pintadas de branco e o teto torna-se a fonte de luz; o piso de madeira é polido para facilitar o deslocamento do visitante, ou, ainda, acarpetado, para que esse transite de maneira silenciosa, descansando os pés, enquanto seus olhos fixam-se nas paredes, atentos à contemplação das obras. A hegemonia do cubo branco, no entanto, entra em crise, de acordo com Hal Foster (2015), à medida que

viu-se pressionado pela obra de arte mais ambiciosa, que, depois da Segunda Guerra Mundial, começou a expandir suas dimensões - das vastas telas de Jackson Pollock, Barnett Newman e outros, passando pelos objetos seriados de minimalistas como Carl Andre, Donald Judd e Dan Flavin, até as instalações vinculadas a espaços específicos, de uma gama de artistas posteriores que vai de James Turrell a Olafur Eliasson (FOSTER, 2015).

Trata-se, pois, da necessidade de adequação dos espaços institucionais à própria crise enfrentada pela arte diante de práticas artísticas que se opunham ao hermetismo ascético da arte moderna, conforme teorizado por Arthur Danto (2010) em "Após o fim da arte", tais como a pop, a arte conceitual, a performance e a infinidade de novas mídias utilizadas principalmente a partir dos anos sessenta.

Ao mesmo tempo, foram realizadas diversas atividades por parte de artistas, principalmente na Europa e nos Estados Unidos, que posteriormente viriam a ser integradas sob o conceito de Crítica Institucional, envolvendo os agora canônicos trabalhos de artistas como Daniel Buren, Marcel Broodthaers, Michael Asher, Hans Haacke, grupos como o Groupe Recherche d'Art Visuel, Art Workers Coalition, Guerrilla Art Action Group, entre tantos outros, cujas propostas remetem às investigações de Marcel Duchamp acerca do status do objeto de arte, no início do século XX, bem como caracterizam-se como desdobramentos 
das práticas de arte conceitual realizadas a partir dos anos sessenta. Com suas propostas, esses artistas criticaram a tradicional separação entre o público e as obras, reivindicando uma maior interação entre ambos, bem como buscaram evidenciar as estruturas de poder, fatores ideológicos e econômicos que alicerçavam as instituições de arte, de modo a entender e criticar a forma como esses elementos influenciavam na escolha dos artistas e trabalhos a serem exibidos em museus e galerias, além de condicionar a produção dos artistas e a própria definição do que era ou não arte. Trata-se do que ficou conhecido com a "primeira geração" da Crítica Institucional. Como exemplos, vemos como em The function of the museum (1970), Daniel Buren (2009) define o espaço institucional como um local privilegiado, com um papel triplo: estético, uma vez que o museu atua como moldura e respaldo para a inserção do trabalho como obra de arte; econômico, já que atribui valor de venda àquilo que exibe e seleciona, ou seja, ao preservar o trabalho ou retirá-lo do lugar-comum, o museu promove-o socialmente, garantindo sua exposição e consumo; místico, pois o museu ou galeria promovem instantaneamente ao status de "arte" tudo aquilo que exibem, de modo que constituem, de acordo com o autor, o corpo místico da arte (BUREN, 2009).

Outro grupo atuante na crítica das instituições de arte, o Groupe Recherche d'Art Visuel, criado em Paris, em 1960, foi formado por pintores interessados em repensar os conceitos de objeto de arte, a relação entre obra e artista, no sentido de uma arte que é controlada e não mais inspirada, a relação entre artista e sociedade, bem como entre obra de arte e público (GROUPE RECHERCHE D'ART VISUEL, 2009). A realização de tais propostas dependia da contestação do papel exclusivo de museus e galerias como lugares especiais para a venda e sublimação das obras de arte, além do entendimento de críticos e estetas como os únicos qualificados a entender e comentar sobre a mensagem artística (GROUPE RECHERCHE D'ART VISUEL, 2009). Em um manifesto de 1966, o grupo destaca o interesse na proliferação de trabalhos que permitam situações variadas, seja por engendrar um forte estímulo visual, demandar uma movimentação por parte do espectador, conter em si mesmos um princípio de transformação ou envolver a participação ativa do espectador (GROUPE RECHERCHE D'ART VISUEL, 1996). O segundo passo, ainda de acordo com o manifesto, seria produzir conjuntos (ensembles) que fariam o papel de “incitamentos sociais”, prezando a participação do público e liberando-o do que o grupo caracterizava como uma "obsessão pela posse [das obras de arte]". Essas estruturas, por sua vez, poderiam assumir a forma de centros de ativação, salões de jogos, que seriam montados e utilizados de acordo com o local e as características dos espectadores, de modo que a 
participação seria coletiva e o público poderia expressar-se para além da fruição individual (GROUPE RECHERCHE D’ART VISUEL, 1996). Também de modo a ampliar a capacidade de interação do visitante com o espaço expositivo, cabe ressaltar as propostas de Michael Asher, como a realizada no Gladys K. Montgomery Art Center, em Pomona College. O artista reconfigurou o espaço do museu em dois triângulos que se intersectavam, requerendo que os visitantes passassem por um estreito corredor onde os triângulos se encontravam (VOORHIES, 2017). Para James Voorhies (2017), a proposta de Asher promoveu a descontrução da galeria a fim de criar um efeito atmosférico único para o visitante e funcionou performativamente por meio do encontro físico dos espectadores com o espaço efetivo da exposição, atingindo uma ruptura sem precedentes com relação ao intocado espaço do museu modernista.

Em outra chave, grupos como a Art Workers' Coalition fizeram, em uma declaração de 1969, demandas como: a obrigatoriedade de inserção, nos conselhos diretivos de museus, de seus funcionários e de artistas, para além de seus patronos, bem como a eliminação da composição desses conselhos com base em critérios financeiros; entrada livre aos museus, a todo momento, e abertura em horários estendidos, de modo a contemplar os trabalhadores; a descentralização dos museus, de modo que suas atividades abarcassem minorias; que os museus encorajassem a superação, por parte de artistas mulheres, dos séculos de representação desigual entre os sexos em exposições, aquisições e em comitês de seleção; patrocínio, por parte dos museus, da produção e exibição de trabalhos fora de suas instalações, por artistas não representados por galerias comerciais (ART WORKERS' COALITION, 2009). As demandas do grupo no que tange à composição dos conselhos diretivos dos museus, por exemplo, dizia respeito ao fato de que aqueles no controle dessas instituições eram os mesmos riquíssimos detentores de todas as agências de comunicação dos Estados Unidos, como a NBC, CBS, The New York Times e Associated Press, além dos detentores de gigantes como a AT\&T, Ford e General Motors, e fundações bilionárias como a United Fruit e Minnesota Mining. Nesse contexto, Gregory Battcock (2009) ressalta como tais patronos da arte eram responsáveis também por travar a guerra do Vietnã, e utilizavam de seu apoio às artes para justificar o massacre de milhões de pessoas lutando por independência e autodeterminação. Assim, Battcock (2009) assinala como museus tais quais o de Arte Moderna de Nova York, o Whitney e o Metropolitan serviam para sustentar valores antiquados e "obsessões distorcidas", não apenas hipócritas, como também opressoras, reacionárias, debilitantes culturalmente, além de social e esteticamente negativas 
(BATTCOCK, 2009). Uma ramificação da Art Workers' Coalition, o Guerrilla Art Action Group também abordou a questão do uso da instituição de arte como esfera de influência por membros de sua diretoria, quando, em 1969, lançou um apelo pela renúncia imediata de membros da família Rockefeller do conselho diretivo do MoMA. O grupo também denunciou a relação entre esses membros abastados e o financiamento da máquina de guerra estadunidense, de modo que, ocupando posições de poder nas instituições de arte, aqueles eram responsáveis pela manipulação das ideias dos artistas e a esterilização de qualquer forma de protesto social ou denúncia das forças opressivas na sociedade (GUERRILLA ART ACTION GROUP, 2009).

Exemplos como esses evidenciam a vontade de diversos artistas que integraram a primeira fase da Crítica Institucional de se manifestarem tanto contra as estruturas de poder que permeavam as instituições de arte, como o próprio sistema de legitimação dos trabalhos, além da diminuta possibilidade de interação entre as obras, o espaço expositivo e o público. Vale notar também como, a partir dos anos oitenta, de acordo com Welchman (2006), a Crítica Institucional é reavaliada por uma segunda geração de artistas como Andrea Fraser, Renée Green, Fred Wilson, entre outros, que se engajaram em intervenções ainda mais interativas e performativas, e por críticos, como Benjamin Buchloh, que ofereceu algumas das primeiras histórias críticas dos pioneiros do movimento. De acordo com Alexander Alberro (2009), muitos desses artistas tentaram conectar as políticas de identidade dos novos movimentos sociais do período, em que Brian Holmes (2008) destaca o feminismo e a historiografia pós-colonial, a novas formas de subjetividade artística, o que implicou, segundo Alberro (2009), na criação de conexões entre a prática artística e várias lutas democráticas contra diferentes formas de subordinação.

Os trabalhos de artistas no contexto da Crítica Institucional são referências essenciais para a reestruturação proposta pelas instituições aqui estudadas, a partir dos anos noventa. Para Nina Montmann (2007), elas teriam internalizado as propostas da primeira e segunda gerações, passando a atuar como "instituições de crítica". Tal termo é sugerido por Andrea Fraser em 2005, no artigo From the Critique of Institutions to an Institution of Critique, publicado pela Artforum, em que a autora assinala mudanças quanto à Crítica Institucional praticada pelas primeiras gerações, bem como realiza importantes esclarecimentos. Fraser (2005) caracteriza a crítica das instituições como anacrônica ao contexto recente, principalmente tendo em vista os megamuseus corporativos e o incessante mercado global de arte, que impossibilitariam os artistas de assumirem uma posição crítica contrária ou exterior 
às instituições de arte. Na realidade, para ela, a própria ideia de que a Crítica Institucional opõe arte à instituição ou supõe que práticas radicais de arte existiram fora da instituição seria incoerente. Fraser (2005) também desconstrói o entendimento das instituições como lugares específicos, organizações e indivíduos, enfatizando sua concepção como campo social, o que torna os limites entre "dentro" e "fora" ainda mais nebulosos. A Crítica Institucional daria então lugar às Instituições de Crítica, de modo que, para a autora, não se trata de ser contra a instituição, mas sim de decidir qual tipo de instituição se quer ser, quais valores internalizar, quais formas de prática recompensar e a quais tipos de recompensas aspirar, decisões que, por sua vez, são tomadas em um processo conjunto entre diretores, curadores e artistas (FRASER, 2005). Sendo assim, consideramos os exemplos abordados ao longo do trabalho como instituições de crítica, de modo que acreditamos na possibilidade de se operar de maneira socialmente responsiva a partir dos mecanismos institucionais, sempre empregando uma autorreflexividade em seus processos e quanto aos possíveis conflitos que possam surgir dentro de suas estruturas.

Outro elemento a ser considerado como referência para as propostas experimentais em questão é a gradual mudança nas funções atribuídas ao curador, de modo que sua figura passa a ganhar cada vez maior proeminência no contexto institucional. Nos primeiros museus modernos, os curadores tinham como tarefa principal zelar pelas coleções e pelos objetos recém adquiridos pelas instituições, de modo que seu papel girava em torno da interpretação e da preservação das obras de arte. Tal configuração esteve presente nos museus de arte ao longo de todo o século XIX e grande parte do século XX, sendo que nas décadas posteriores à Segunda Guerra Mundial, passa a haver uma mudança quanto ao "curador de museu”, para o que eventualmente viria a ser chamado "autor de exposições", ou seja, a noção de curador que temos atualmente (MARTINI, F.; MARTINI, V., 2010). Para Federica Martini e Vittoria Martini (2010), é apenas nos anos sessenta que o debate sobre o que era um curador de fato se inicia, à medida que emerge uma figura que não é necessariamente um historiador da arte, mas um apaixonado por práticas artísticas contemporâneas, que viaja para conhecer artistas e visitar exposições, um intelectual que faz juízos de valor baseados em sua própria experiência. Desse modo, ao ser convidado para organizar uma exposição, esse novo profissional seleciona artistas de acordo com sua visão crítica específica sobre um tema ou uma questão (MARTINI, F.; MARTINI, V., 2010).

Nota-se, então, uma reconfiguração quanto ao papel do curador dentro das instituições, que não mais se caracteriza como responsável unicamente pela seleção, obtenção 
e instalação de obras para uma exposição, e sim passa a desempenhar funções administrativas, determinar quadros conceituais, selecionar colaborações especializadas advindas de várias disciplinas, dirigir equipes, consultar arquitetos, assumir uma posição formal em termos de apresentação e organizar a publicação de catálogos (HEINICH; POLLAK, 1996).

É também a partir dos anos sessenta, de acordo com Federica Martini e Vittoria Martini (2010), que os curadores passam a subverter os formatos expositivos, de modo que a reflexão crítica acerca da relação entre as obras de arte e o espaço expositivo, que, desde movimentos de vanguarda histórica, e, como vimos, com as práticas de Crítica Institucional, vinham sendo principalmente desenvolvidos por artistas, passaram a integrar também o trabalho curatorial. As autoras destacam que exposições organizadas por curadores como Seth Siegelaub, Lucy Lippard e Harald Szeemann contribuíram para uma revisão quanto à forma como as mostras eram concebidas e, como resultado desses esforços, foram propostas novas definições a respeito da figura do curador (MARTINI, F.; MARTINI, V., 2010). Entre elas, é citada a noção de "realizador de exposições", cunhada por Szeemann ao deixar a Kunsthalle de Berna, em 1969, tendo ele ficado conhecido como o primeiro curador independente. Para Federica Martini e Vittoria Martini (2010), a definição desse novo papel do curador e o discurso da autoria curatorial ocorreu em paralelo ao estabelecimento de novas formas de colaboração entre artistas e organizadores de exposições. Terry Smith (2015), no livro Talking Contemporary Curating, destaca as intensas trocas entre artistas e curadores durante os anos sessenta e setenta, interação que teria moldado as práticas de ambos desde então.

De acordo com Paul O’Neill (2012), após notáveis exposições realizadas por curadores independentes, tais como Live in Your Head. When Attitudes Become Form. Works, Concepts, Processes, Situations, Information (1969), de Harald Szeemann; January 5-31, 1969 (1969), de Seth Siegelaub; Op losse schroeven: Situaties en cryptostructuren (1969), de Wim Beeren; Anti-Illusion: Procedures/Materials (1969), de Marcia Tucker e James Monte; Spaces (1969-1970), de Jennifer Licht; e Information (1970), de Kynaston McShine, tanto artistas como curadores ganharam reconhecimento internacional e a produção curatorial, nesses casos, consistiu no agrupamento de trabalhos de artistas com preocupações similares, o que fez com que a forma da exposição fosse tratada como um meio em si mesma. Para O’Neill (2012), a exposição tornou-se então identificada com o estilo característico de cada curador-produtor e sua habilidade de contextualizar uma amplitude de trabalhos sob um mesmo conceito. 
Em When Attitudes Become Form, os artistas participantes tiveram total liberdade sobre o espaço da Kunsthalle de Berna, que atuou como um estúdio para o desenvolvimento de seus trabalhos. Szeemann, em entrevista para Hans Ulrich Obrist na Artforum, em 1996, assinalou como a experiência foi uma aventura do início ao fim, um momento de grande intensidade e liberdade, no qual os artistas podiam produzir um trabalho ou apenas imaginálo. O curador explica como sessenta e nove artistas europeus e americanos dominaram a instituição, de modo que a Kunsthalle se transformou em um verdadeiro laboratório (SZEEMANN, 1996) ou, ainda, em um "canteiro de obras", de modo que todas as partes do museu estavam tomadas por atividades (WILLIAMS, 2000), além de haver trabalhos espalhados pela cidade. O resultado foi, para os padrões normais, uma bagunça, com um número exagerado de trabalhos expostos juntos no mesmo espaço, partes inadequadas do museu sendo utilizadas para fins expositivos, obras não instaladas propriamente ou simplesmente não instaladas, ou ainda atribuídas erroneamente (WILLIAMS, 2000). As fotos da exposição, de acordo com Williams (2000) mostram, por exemplo, em uma das salas, uma grande peça de feltro de Robert Morris entre três obras de Bruce Nauman, também de larga escala, ocupando todo o espaço de parede disponível. Na mesma sala, trabalhos de Alighiero Boetti e Barry Flanagan ocupavam todo o espaço do chão, tornando difícil a entrada dos visitantes sem que pisassem sobre as obras. Sendo assim, o caos foi, para Williams (2000), o principal tema do discurso crítico em torno da exposição, tendo sido visto, no entanto, como uma força positiva: Tomasso Trini, por exemplo, descreveu a contraditoriedade da exposição como atrativa, enquanto Gregoire Müller descrevou o caos como libertador (WILLIAMS, 2000).

Abrindo um parêntese, se remontarmos ao contexto brasileiro, cabe assinalar como a pesquisadora Dária Jaremtchuk (2012) equipara, tomadas as devidas proporções, a exposição When Attitudes Become Form à sexta edição da mostra Jovem Arte Contemporânea (JAC), realizada em 1972. As JAC's foram exposições abertas e experimentais que visaram estimular jovens artistas e a arte emergente, organizadas no Museu de Arte Contemporânea (MAC) de São Paulo, sob a direção de Walter Zanini. Em sua sexta edição, a seleção dos participantes foi feita por meio de sorteio, os quais, "em vez de exibir obras, ocupariam lotes para desenvolver/apresentar seus projetos durante um tempo determinado" (JAREMTCHUK, 2012:77). Desse modo, de acordo com a autora, o espaço expositivo do Museu passou a funcionar como uma espécie de laboratório, "que transferia o centro de gravidade do objeto de exposição para seu agente propositor" (JAREMTCHUK, 2012:78) e de modo que, "dentro 
do espírito das mostras processuais daquele momento, um projeto e seu desdobramento no tempo poderiam ser mais significativos do que a apresentação de objetos" (JAREMTCHUK, 2012:78).

Em Op losse schroeven: Situaties en cryptostructuren (1969), realizada no Stedelijk Museum, em Amsterdã, o curador Wim Beeren buscou destacar as várias novas direções que os artistas da época estavam buscando, como a Arte Conceitual, Arte Povera e PósMinimalista, dotadas de um espírito experimental, além de chamar atenção para as performances efêmeras e intervenções conceituais que ocorriam do lado de fora das paredes do Museu (STEDELIJK, s.d). Op losse schroeven foi instalada nas galerias de exposições temporárias do Stedelijk Museum, que ocupavam o conjunto de doze salas do piso térreo da ala oeste do Museu. Os trabalhos também foram dispostos sobre e abaixo das escadas, no hall de entrada e do lado de fora. Em alguns casos, o Beeren seguiu o layout mais previsível de um artista por sala, adotando, no entanto uma disposição que sugeria mais um "depósito" das obras do que sua exibição: frequentemente situadas ao longo dos perímetros das salas, elas irradiavam "para dentro" a partir de cantos, beiras e paredes, raramente avançando do centro para fora (CHERIX, 2009). Entre os trabalhos expostos nas galerias, estavam obras sitespecific, como Pedestal for the Museum (1969), de Jan Dibbets, para o qual ele cavou pequenas trincheiras ao redor dos quatro cantos do Stedelijk, expondo sua fundação, e depois as diagramou como partes imaginárias de um monumental pedestal no qual o Museu estava assentado. Também havia obras de Arte Povera, como Écriture Brûlée (1968), de Gilberto Zorio, que consistia em uma escultura de uma caixa feita de tela metálica, similar a uma gaiola, acompanhada de um bloco de papel no qual os visitantes eram convidados a riscar uma mensagem com uma caneta de metal antes de jogar seu bilhete na caixa, no fundo da qual os papeis seriam incinerados por uma placa de metal aquecida. Entre as instalações, estava um trabalho sem título de Walter De Maria: um colchão, colocado no chão em posição central, no qual os visitantes poderiam reclinar e escutar os sons do oceano por meio de fones. A exposição também contou com earth-works, como uma instalação de Richard Long que consistia em uma "área murada", construída com pedras coletadas em vários leitos de rios ao redor da cidade. Ao sair das galerias, os visitantes poderiam continuar para a sala localizada embaixo das escadas, que exibia documentação de land art de Dennis Oppenheim e Michael Heizer (CHERIX, 2009). Para Christophe Cherix (2009), a exposição estava organizada de modo a formar percursos que moviam os visitantes de trabalhos escultóricos relativamente tradicionais em direção a um ambiente virtualmente imersivo, além de emular as conexões 
formadas entre objetos no estúdio, ao invés da justaposição rigidamente construída do modo de exibição do museu (CHERIX, 2009).

Sobre Anti-Illusion: Procedures/Materials (1969), curada por Marcia Tucker e James Monte e realizada no Whitney Museum, em Nova Iorque, Monte (1969) destaca que a natureza radical de vários trabalhos dependia menos do fato de que novos materiais estavam sendo utilizados por artistas, do que dos atos de concepção e disposição dos trabalhos precedederem sua qualidade de objeto. Importava menos ainda, segundo o curador, que Barry Le Va, Robert Morris, Rafael Ferrer ou Michael Asher utilizavam materiais como feltro, feno, gelo, giz, grafite, ar ou tecido, pois o simples fato de sua inclusão em obras de arte era muito menos interessante que o modo como eles eram utilizados. Durante a organização da exposição, os curadores perceberam que os procedimentos habituais de seleção de trabalhos não poderiam ser seguidos. Assim, após visitarem vários estúdios e galerias bem como analisarem slides e fotografias, eles decidiram que a maioria da exposição seria composta por obras nunca antes vistas e realizadas para a ocasião. Desse modo, a própria natureza dos trabalhos deveria ser determinada por sua localização naquele espaço particular, considerada não apenas como um local para sua realização, mas como uma "armadura" integral e inextricável, necessária para sua existência (MONTE, 1969).

A exposição Spaces (1969-1970), realizada no MoMA de Nova Iorque, consistiu na seleção, pela curadora Jennifer Licht, dos artistas Michael Asher, Larry Bell, Dan Flavin, Robert Morris, Franz Erhard Walther e o Grupo Pulsa, para que esses criassem espaços individuais no primeiro andar e no Jardim de Esculturas do Museu (MOMA, 1969a), sendo que o interesse comum desses projetos residia em uma experiência espacial abrangente como condição primária da obra de arte (MOMA, 1969b). Dessa forma, a exposição, para qual as obras de arte e as salas foram construídas de acordo com as necessidades dos artistas, serviu para desafiar a função tradicional do museu e realizar demandas incomuns de seus recursos de modo que, se um museu usualmente tinha a função de abrigar e conservar objetos de arte, passou a tornar-se responsável pela execução das ideias dos artistas, o que, por sua vez, demandava a colaboração de pessoas e o ajuste flexível de papeis e áreas de responsabilidade (MOMA, 1996a).

No caso da Information (1970), o curador da exposição, Kynaston McShine, observa como buscou-se pensar para além das categorias tradicionais da arte, de modo que suas distinções se diluíram. Ainda, os jovens artistas participantes abraçaram a questão de como criar uma arte que se estendesse para um público mais amplo do que o interessado em arte 
contemporânea à época. De acordo com McShine (1970), a atividade dos artistas foi pensar em conceitos mais amplos que o previsível "produto" do estúdio, de modo que, com o senso de mobilidade e mudança que permeava aqueles tempos, os artistas interessavam-se mais pela troca de ideias, do que por embalsamá-las em um objeto ${ }^{1}$. A atitude geral dos artistas era clara, amigável e permitia experiências inovadoras, possibilitando a participação, fazendo os visitantes questionarem a si mesmos e suas respostas a estímulos desconhecidos (MCSHINE, 1970). Havia também a demanda constante de uma relação mais consciente com os ambientes naturais e artificiais de cada um; os artistas estavam contestando os preconceitos dos participantes, convidando-os a renunciar a suas inibições, e, uma vez que reavaliavam a natureza da arte, também pediam que os participantes reacessassem o que sempre haviam tomado como natural no que diz respeito a uma resposta estética culturalmente condicionada com relação à $\operatorname{arte}^{2}$ (MCSHINE, 1970).

Vale destacar também, no contexto dessas exposições, a importância do papel desempenhado pelas publicações, de modo que elas atuaram como verdadeiros complementos às exposições. O catálogo de Attitudes, por exemplo, continha proposições de trabalhos não realizados na ocasião (WILLIAMS, 2000), enquanto, no caso da Information, cada um dos artistas participantes foi convidado a criar sua própria contribuição para a publicação, de modo que os materiais apresentados poderiam ser diretamente relacionados aos trabalhos presentes na exposição, ou até mesmo deles independentes (MSCHINE, 1970). Já em January 5-31, 1969 (1969), exposição coletiva organizada por Seth Siegelaub, o catálogo foi o principal suporte do projeto, de modo que, durante a exposição, realizada em um espaço temporário em Manhattan, algumas obras foram expostas em uma sala, e o catálogo em outra (MOMA.ORG).

Com relação a essas históricas exposições, cabe destacar o caráter experimental e processual presente em todas elas, de modo que essas se constituíram como espécies de

\footnotetext{
${ }^{1}$ The activity of these artists is to think of concepts that are broader and more cerebral than the expected "product" of the studio. With the sense of mobility and change that pervades their time, they are interested in ways of rapidly exchanging ideas, rather than embalming the idea in an "object" (MCSHINE, 1970, p. 139).

${ }^{2}$ The general attitude of the artists in this exhibitionis certainly not hostile. It is straightforward, friendly, coolly involved, and allows experiences which are refreshing. It enables us to participate, quite often as in a game; at other times it seems almost therapeutic, making us question ourselves and our responses to unfamiliar stimuli. The constant demand is a more aware relation to our natural and artificial environments [...] These artists are questioning our prejudices, asking us to renounce our inhibitions, and if they are reevaluating the nature of art, they are also asking that we reassess what we have always taken for granted as our accepted and culturally conditioned aesthetic response to art (MCSHINE, 1970, p. 141).
} 
laboratórios ou espaços semelhantes aos próprios estúdios dos artistas, desafiando a configuração tradicional dos espaços expositivos, bem como propiciando aos visitantes um novo tipo de experiência com o espaço e os trabalhos. Foi possível notar também o papel complementar e enriquecedor que as publicações desempenharam com relação a essas exposições. Trata-se, pois, de elementos tomados como referência pelos curadores e diretores das "novas" instituições experimentais em questão, e aplicados às suas empreitadas.

Diante dos novos formatos das manifestações artísticas, bem como diversas proposições, tanto por parte de artistas como de curadores, para promover reorganizações quanto às estruturas institucionais e mesmo à configuração dos espaços expositivos, que até então ofereciam pouca possibilidade de interação por parte dos visitantes, Isabel García Fernandez (2015) assinala, desde o final dos anos sessenta, uma gradual mudança quanto à missão tradicional de alguns museus, inicialmente voltados para o estudo e conservação de suas coleções, e que passam a buscar maneiras de torná-las mais acessíveis ao público tanto conceitual como fisicamente. De acordo com Fernandez (2015), as formas de apresentação das coleções têm sido renovadas pelas instituições a fim de abarcar a comunidade e manter contato com seus visitantes por meio do compartilhamento da memória, o que propiciaria, por sua vez, a conexão entre diferentes tipos de coleções e seus públicos. A autora nota como tem sido discutida a forma como as instituições de arte devem considerar sua contribuição para a sociedade, de modo que se tem cobrado dos museus que reflitam sobre sua missão e objetivos, além de que esses convertam-se em instrumentos que melhorem a vida dos cidadãos, e não apenas proporcionem um refúgio que os evada da vida cotidiana, ou que sejam simples repositórios de conhecimentos e bens patrimoniais (FERNANDEZ, 2015). Nesse entendimento, ainda de acordo com Fernandez (2015), os museus devem contemplar os interesses e necessidades dos indivíduos e da sociedade, de modo a colocar-se a seu serviço, além de se implicar na preservação das tradições e servir de apoio à educação de todo tipo de público, sempre buscando maneiras de se tornar relevantes para a comunidade.

Podemos então perceber como as propostas de reestruturação institucional a partir dos anos noventa advêm de um processo contínuo de questionamento acerca da configuração tradicional dos museus de arte, que tinham no colecionismo sua principal preocupação, enquanto os visitantes eram considerados como figuras passivas, receptores unilaterais das informações e do conhecimento por eles difundido. Sendo assim, as instituições experimentais em questão no presente trabalho estão em consonância com a noção do que Eilean Hooper Greenhill (2007) chamou de "pós-museu”, de modo que, enquanto no museu 
modernista a exibição é a principal forma de comunicação, abordagem que possui severas limitações, no pós-museu, ela atuaria como uma entre diversas formas de comunicação, integrando parte de um núcleo de eventos que ocorrem antes e após sua montagem, e que podem envolver elementos como: o estabelecimento de parcerias comunitárias e organizacionais; a produção de objetos durante programas educacionais, que então podem ser incorporadas às coleções; períodos em que grupos específicos da comunidade utilizam os espaços do museu à sua própria maneira; residências de artistas, cientistas e escritores; exibições satélite, montadas fora do espaço do museu; realização de discussões, workshops, performances, danças, música e refeições (HOOPER-GREENHILL, 2007). Para HooperGreenhill (2007), a produção de eventos e exposições como parte de uma dinâmica conjunta possibilita a incorporação de várias vozes e perspectivas ao museu, de modo que o conhecimento deixa de ser monolítico e unificado e torna-se fragmentado e multivocal: não existe uma perspectiva única e necessária, mas sim uma cacofonia de vozes que apresentam uma variedade de visões, experiências e valores. Nesse contexto, a voz do museu se torna uma em meio a muitas. Desse modo, enquanto o museu modernista era e ainda é imaginado como um local físico específico, o pós-museu deve ser imaginado como um processo ou uma experiência, assumindo formas arquiteturais diversas. Ainda, ele não se limita a suas próprias paredes, mas sim flui através dos espaços, preocupações e ambições das comunidades ${ }^{3}$ (HOOPER-GREENHILL, 2007).

No artigo From Being About Something to Being For Somebody, Stephen Weil (2012) destaca, nos últimos cinquenta anos, a tendência de ascensão de uma corrente em que os museus tiveram um deslocamento da ênfase quanto ao estudo e conservação de sua coleção, para a oferta de uma variedade de serviços educacionais ao público. Ele atenta, no entanto, para o entendimento de que as atividades tradicionais de preservação, interpretação e pesquisa não devem ser tratadas como meros aspectos instrumentais e devem ser valorizadas. Weil (2012) defende a emergência de um novo modelo de museu, uma instituição transformada e redirecionada que, por meio de seus serviços públicos, utiliza suas competências para contribuir positivamente para a qualidade das vidas humanas individuais, bem como para melhorar o bem-estar das comunidades.

Para abordar as comunidades às quais o museu se dirige, Mason (2005) se utiliza do termo "comunidades interpretativas", cunhado por Stanley Fish (1980), no âmbito da crítica

\footnotetext{
${ }^{3}$ [the post-musem] is, however, not limited to its own walls, but moves as a set of process into the spaces, the concerns and the ambitions of communities (HOOPER-GRENHILL, 2007, p. 82).
} 
literária, para referir-se a grupos de pessoas que compartilham "estratégias interpretativas", percepções e visões de mundo. Mason (2005) as divide em seis grupos, que podem ser definidos: por experiências culturais ou históricas compartilhadas; por seu conhecimento especializado; por fatores demográficos e socioeconômicos; por suas identidades (nacional, regional, local ou relacionadas à sexualidade, idade e gênero); por suas práticas de visitação; por sua exclusão quanto a outras comunidades.

Outro aspecto relevante a ser ressaltado para os efeitos da presente contextualização diz respeito ao intenso envolvimento das corporações no campo da arte e da cultura, a partir dos anos 80. De acordo com Chin-Tao Wu (2006), o interesse do mundo dos negócios nas atividades culturais

[...] em particular quando são publicamente endossadas pelo governo, deve ser visto como parte de uma estratégia global para reunir o poder econômico privado e a autoridade cultural pública. Isso é feito com a expectativa de que o capital cultural assim criado possa, no devido tempo e na conjuntura adequada, transformar-se em poder político para atender, abertamente ou não, aos interesses econômicos específicos dessas corporações (WU, 2006, p. 39).

Mark Rectanus (2002) argumenta que as corporações institucionalizaram suas próprias políticas culturais, de modo que, apesar de sua contribuição relativamente pequena para o financiamento cultural, essas empresas têm definido as agendas públicas e privadas da programação cultural. Isso se deu à medida que modelos corporativos de operação e gerenciamento institucional foram sendo cada vez mais legitimados por instituições governamentais, sem fins lucrativos e educacionais (RECTANUS, 2002). Instaura-se, assim, uma relação em que as corporações e entidades comerciais desenvolvem suas próprias formas e estratégias de políticas culturais, por exemplo, por meio de patrocínios, a fim de manter e expandir sua esfera de influência política, ao passo que instituições públicas e sem fins lucrativos passam a adotar e modificar estratégias corporativas a fim de garantir reconhecimento público e estabilidade financeira (RECTANUS, 2002).

Um problema se instaura, nesse contexto, a partir do momento em que o imperativo de uma lógica de Mercado passa a reger as atividades das instituições de arte. Como resultado, a programação das instituições de arte acaba, em sua maioria, por ser ditado pelo entretenimento, que atuam como ferramentas para atrair o maior número de visitantes possível, deixando de lado a possibilidade de suscitar a reflexão e a criticidade em seus espaços. Também Rosalind Krauss, no artigo The Cultural Logic of the Late Capitalist Museum, escrito em 1990, destaca como o espírito do livre mercado dos anos oitenta 
remodela a noção de museu, que, de guardião do patrimônio público, passa a ser compreendido como uma entidade corporativa com um inventário altamente comercializável, amparada no desejo por crescimento (KRAUSS, 1990). Sintoma de tal remodelação é o advento do que Hal Foster (2015) chama de modelo de "museu como ícone": espaços monumentais projetados por arquitetos famosos, que se tornam "emblemas midiáticos" a serviço da nova economia do turismo cultural. Como exemplos, Foster (2015) cita o Guggenheim de Bilbao, projetado por Frank Gehry e o MAXXI (Museu Nacional das Artes do Século XXI) de Roma, desenhado por Zaha Hadid e ressalta que, em casos como esses, os "museus são tão esculturais que a arte que apresentam é secundária, figurando apenas em segundo plano" (FOSTER, 2015). Ainda, para ele, tal tendência à construção e renovação de museus de forma monumental está ligada a um "megapropósito, tão óbvio que nem é enunciado: o do entretenimento" (FOSTER, 2015). Isso pode ser explicado, de acordo com Voorhies (2017), pela tendência à consideração das principais instituições de arte como motores econômicos, de modo que são incumbidas de oferecer experiências para os visitantes, transformados em consumidores no que emergiu como uma indústria cultural globalizada (VOORHIES, 2017).

Frente a esse cenário, podemos assinalar mais uma das características distintivas das instituições experimentais em questão, que diz respeito à intenção de opor-se ao modelo de instituição baseado no entretenimento e guiado unicamente por uma lógica de mercado, no qual elementos como a atração de público acabam por ser mais relevantes que o trabalho reflexivo, colaborativo e horizontal junto aos visitantes e membros de sua comunidade.

Há exemplos tanto de instituições colecionadoras que procuram manter esse tipo de diretrizes, como é caso do MACBA, bem como centros de arte que não possuem acervo, como o Rooseum e tantos outros. No primeiro caso, vale notar como Claire Bishop (2013) introduz o conceito de Museologia Radical (Radical Museology), que diz respeito a um modelo mais experimental de museu, menos determinado por sua arquitetura, e que oferece um engajamento mais politizado com o atual momento histórico. A autora cita como exemplos três museus europeus: o Van Abbemuseum, em Eindhoven, o Museu Nacional Centro de Arte Reina Sofía, em Madrid, e o Muzej sodobne umetnosti Metelkova (MSUM), em Ljubljana (BISHOP, 2013). Para a autora, essas instituições, orientadas por compromissos políticos claros, diferenciam-se do modelo presentista de museu de arte contemporânea, no qual os interesses de mercado influenciam no que é exposto, de modo que cada uma dessas instituições utiliza de sua coleção para sugerir uma reflexão provocativa acerca da arte contemporânea em termos de uma relação específica com a História, motivada por um senso 
de urgências sociais e políticas do presente (BISHOP, 2013). Assim como Bishop cunha o termo Museologia Radical para marcar diferenças com relação ao modelo tradicional de museu, Charles Esche (2001) também o faz ao tratar dos centros de arte. O curador acredita que um centro de arte, em oposição a um museu (pelo menos em seu sentido tradicional), deve criar um espaço de reflexão e discussão para artistas, grupos criativos e indivíduos, dando forma de expressão à mudança social. Acerca do surgimento da noção de centro arte, por sua vez, destaca-se a criação do Centre Pompidou, inaugurado em 1977, no que tange à concentração, em um mesmo espaço, de uma variedade de atividades como apresentações de música, teatro, cinema, exposições, entre outras, de modo que antes cada uma delas existia em instituições isoladas (DABUL, 2008).

Neste primeiro capítulo, pudemos realizar uma contextualização acerca de importantes mudanças que antecedem, bem como atuam como referências para a proposição de programas experimentais dentro de diversas instituições, a partir do final dos anos noventa. Observamos a gradual adequação das instituições de arte frente às novas manifestações artísticas desenvolvidas principalmente a partir dos anos sessenta, em direção a modelos mais participativos e a serviço da comunidade. Ao abordar exemplos das diversas práticas de Crítica Institucional, desde sua primeira geração, entendemos que seus questionamentos quanto às estruturas das instituições de arte puderam ser assimilados para a proposição de uma autorreflexão quanto a seus processos, o que diz respeito não a um descrédito nas instituições, mas sim à convicção de que seus mecanismos possam ser utilizados de forma crítica e socialmente responsável. Também pudemos verificar como a figura do curador passa a ganhar proeminência no contexto institucional, assumindo a autoria de exposições, além de diversas outras tarefas. Desse modo, foram citados casos paradigmáticos de exposições experimentais e processuais organizadas por curadores, que buscaram subverter os formatos expositivos tradicionais e ampliar a possibilidade de engajamento do público com os trabalhos. Tais casos serviram, por sua vez, como referência para os curadores que assumiram, a partir do final dos anos noventa, o comando de diversas instituições de arte, e buscaram aplicar essas propostas na elaboração de seus programas. Outra questão pontuada foi como as instituições experimentais aqui analisadas surgem para fazer frente a um modelo de instituição guiado por imperativos mercadológicos, que entram em jogo à medida que o envolvimento corporativo no campo da cultura se faz cada vez mais presente, de modo que suas propostas são orientadas para a realização de processos críticos e reflexivos, ao invés de serem pautadas no entretenimento em busca do maior número de visitantes e, no entanto, 
esvaziadas de discussão. Por fim, notamos aproximações das experimentações institucionais em questão com o conceito de Museologia Radical, cunhado por Claire Bishop, no caso de instituições colecionadoras, bem como quanto à noção de centros de arte, que surge a partir do advento do Centre Pompidou, em 1977. 


\section{ALGUNS CASOS DE EXPERIMENTAÇÕES INSTITUCIONAIS}

Neste capítulo, são abordados exemplos de programas e projetos realizados por instituições experimentais durante a gestão de diretores específicos, a fim de melhor ilustrar os tipos de atividades consideradas importantes para este trabalho. Cabe ressaltar que as fontes consultadas para tratar desses centros de arte foram essencialmente oficiais, como os próprios sites das instituições e entrevistas dadas por seus diretores, de modo que não foram verificados os resultados efetivos dos programas aqui citados, mas sim baseamo-nos nos discursos, nas intenções e propostas dos diretores das instituições comentadas.

\subsection{ROOSEUM}

Um exemplo importante, como vimos, ao se tratar de experiências institucionais, é o Rooseum, localizado na cidade sueca de Malmö, mais especificamente quando de sua direção por Charles Esche, entre 2000 e 2004. O diretor enfatiza como cabe aos centros de arte contemporânea ser responsivos às mudanças sociais, bem como criar possibilidades para a sociedade na qual se encontram. Para ele, uma forma de fazê-lo é adotando uma espécie de fluidez: nesse caso, uma instituição fluida deve ser autocrítica, mutável e não-doutrinária, um lugar aberto à imaginação de inúmeras possibilidades (ESCHE, 2001). Tal imaginação, por sua vez, provém, não apenas dos artistas, mas também dos visitantes e integrantes da instituição. Para Esche (2001), um centro de arte contemporânea deve ser especulativo: tem de estar disposto a fazer perguntas acerca de seu próprio status e propósitos e testar ideias em resposta a essas questões ${ }^{4}$. O diretor explica como, em 2001, definiu as missões do Rooseum, de modo que, para ele, uma vez que a arte se tornou um espaço de experimentação, questionamento e descoberta, de caráter ativo, em detrimento de um espaço de observação passiva, a instituição de arte precisaria tornar-se, para abarcar tal condição, parte centro comunitário, parte laboratório e parte academia, de modo que, nesse cenário, a função de espaço expositivo perderia seu papel de protagonismo (ESCHE, 2004). Para Esche (2004),

\footnotetext{
${ }^{4}$ As institutions, art centers are still rightly required to serve and create possibilities for the society in which they find themselves. One way to do this is to imitate the fluidity of capitalism. A fluid institution would be self critical, changeable, and uncertain, and therefore also not especially doctrinaire, a place where anything imaginable is possible within the bounds of the law. That imagination comes from artists but also from visitors and the constituents that make up the institution. A center for contemporary art has to be speculative. It has to be willing to ask questions about its own status and purpose and try out ideas in response to these questions (ESCHE, 2001).
} 
uma vez que a instituição de arte tem o potencial de tornar-se um "fórum político imaginativo", ela deve começar por definir seus atores sociais de modos mais complexos que artistas, curadores e espectadores, e imaginar novas possibilidades de trocas entre eles. Dessa forma, ele afirma que gostaria de imaginar o Rooseum e organizações similares como espaços de "desvio democrático", nos quais ideias são aportadas por todos os participantes e questões são levantadas e discutidas durante um período mais longo, que não apenas um único evento expositivo $^{5}$ (ESCHE, 2004).

A primeira proposta de Esche para o Rooseum foi a de promover uma mudança na identidade da arquitetura do prédio, haja vista que a instituição estava instalada dentro de uma estação de eletricidade. Desse modo, os três pisos seriam separados em termos de "função", com estúdios e uma sala de projetos no andar de cima, um salão principal para exposições e produções de larga escala no piso térreo, e um arquivo e microcinema no andar debaixo (ESCHE, 2001). Outra proposta implementada foi a de convidar artistas não apenas para exibir seus trabalhos, mas também para usar o Rooseum como uma ferramenta funcional, por meio do recebimento de verbas para visitas de pesquisa, a utilização do espaço e de equipamentos como computadores, etc. O diretor destaca como almejava-se que o público tivesse diferentes modos de comportamento no espaço da instituição, algumas vezes como observadores, mas muitas outras como participantes ativos, e de modo que se sentisse livre para experimentar diferentes papeis (ESCHE, 2001).

A primeira exposição organizada sob a direção de Charles Esche no Rooseum foi $V i$ : Intentional Communities, realizada de maio a agosto de 2001. O texto fornecido pelo Rooseum à época explicava como a exposição partiu de um questionamento acerca do que define uma comunidade e de que maneira os artistas estavam discutindo política, solidariedade e o "viver junto" (KUNST ASPEKTE, 2001). A exposição contou com uma pequena porção de material histórico sobre comunas e comunidades dos anos setenta, incluindo a comuna Friedrichshof, na Áustria, embora a maior ênfase tenha sido sobre trabalhos contemporâneos que propunham diferentes modelos de vivência, bem como projetos responsáveis por criar comunidades à época (KUNST ASPEKTE, 2001). Os trabalhos exploraram várias comunidades, tanto reais quanto imaginárias, propondo novos

\footnotetext{
${ }^{5}[\ldots]$ Art and its institutions need to move in an opposite direction if they are to play the role of political imagination forum [...] If the art institution today has the potential to become such a place, it must begin by being defined its constituent social actors in more complex ways than artists, curators and viewers and to imagine new forms of exchange between them. I would like to imagine that the Rooseum and similar organisations become spaces of 'democratic deviance', where ideas [...] are contributed from all participants and issues are raised over a longer period than a single exhibition event (ESCHE, 2004).
} 
coletivos, criando mundos sociais privados e documentando grupos existentes ${ }^{6}$. Além da exposição, também foi realizado um programa de discussões com indivíduos de diferentes comunidades, grupos de artistas, agências e organizações ativistas na região, que acompanhariam a exposição. Intentional communities serviu, pois, para introduzir o novo programa de atividades do Rooseum, sob a direção de Esche, de modo que atuou como um convite ao público para que eles mesmos se identificassem como uma comunidade, bem como se envolvessem no processo de reimaginação do centro de arte, definindo-o como um lugar enraizado na região, ao mesmo tempo em que esse estendia-se para o mundo (KUNST ASPEKTE, 2001).

Esche (2004) constatou o modo como projetos e exposições, tais quais Superflex Supertools e Baltic Babel - cities on a nervous coast, além da residência de longo termo e programa comissionado In 2052 Malmö will no longer be Swedish, forneceram uma visão crítica a respeito de temas como engajamento público, regionalismo e identidade cultural. Ele ainda ressalta iniciativas desenvolvidas com relação a Malmö, concentrando-se sobre os diferentes elementos observados na cidade e em sua história. Nesse sentido, Esche (2004) cita o programa Öppet Forum, formado por grupos locais que desenvolveram suas próprias atividades dentro de um espaço no Rooseum, as quais envolveram desde design de móveis até uma importante iniciativa denominada Curiocity, organizada pelo grupo Aeswad, e que introduziu várias comunidades marginalizadas à instituição e às possibilidades da atividade cultural como forma se fazerem ouvidas.

Esche (2004) cita também o programa internacional de Estudos Críticos do Rooseum, que, de acordo com ele, criou um contexto "internacional-local", e possibilitou que jovens artistas, curadores e críticos contribuíssem para o reservatório de ideias e projetos em torno da instituição. Ele destaca como muitas das abordagens realizadas pela instituição priorizaram a persistência do trabalho artístico a longo prazo, em detrimento do espetáculo da exposição. A intenção foi realizar residências, iniciativas de estudos, projetos de fórum aberto e pequenas apresentações de trabalho, de modo a promover uma instituição ativa e pensante junto à cidade (ESCHE, 2004). O diretor também ajudou a fundar um programa de arte educação na Edinburgh College of Art, chamado Protoacademy, e que surgiu para vislumbrar modelos mais efetivos para a educação avançada em arte, além de funcionar como ponto de encontro

\footnotetext{
${ }^{6}$ A seção de apresentação de obras incluiu filmes, fotografias e instalações esculturais, por artistas como Pawel Althamer, Elisabeth Arkipoff, Johanna Billing, Phil Collins, Annika Eriksson, Jakob Kolding, Mike Nelson, Philippe Parreno, Arturas Raila, Sean Snyder, Jasmila Zbanich, Andrea Zittel \& Joachim Hamou, entre outros (KUNST ASPEKTE, 2001).
} 
para vários especialistas acadêmicos, artistas, escritores e o público em geral (STJERNSTEDT, 2001). Vale destacar também, o programa Nomadsland, que fez parte de Intentional Communities, e foi organizado por estudantes da Malmö Art Academy junto aos estudantes de Edimburgo, de modo a criar séries de discussões em diferentes locais na região de Malmö, incluindo negócios, projetos de moradia e reuniões profissionais, que foram, para Esche (2001) surpreendentemente bem-sucedidas.

Quando olha para trás, analisando sua gestão no Rooseum, Esche (2011) considera-a como um período produtivo, em que seu pequeno time de colegas foi muito aberto e encarou o desafio de tirar a instituição de uma "zona de conforto". Ao mesmo tempo, o diretor acredita que conseguiu criar um público por meio das atividades realizas no centro de arte, ao mesmo tempo que esse mudou radicalmente, já que, ao final de sua gestão, havia menos visitantes gerais e muito mais grupos especificamente engajados ou indivíduos trabalhando junto aos projetos da instituição, ou mesmo retornando para observar o desenvolvimento de programas de longo prazo (ESCHE, 2004). Em entrevista, ao ser questionado se acreditava que a experiência no Rooseum teve um impacto social real e atingiu uma audiência mais ampla, ou se na verdade teria funcionado mais como um modelo ou uma proposta, o diretor explica que o Rooseum atuou sim como um modelo, o que não significa que por trás não houvesse um sonho de atingir um maior público. Assim, para Esche (2011), havia uma ambição em atingir um público amplo, de ter sobre ele um grande impacto, e, ao mesmo tempo, havia a noção de uma certa impopularidade do programa, de modo geral. Para ele, o Institucionalismo Experimental vinha sendo importante por incentivar instituições como a Tate Modern, o Centre Pompidou e o Museo Nacional Centro de Arte Reina Sofía a aumentar seu espaço para experimentação. O diretor defende a relação entre as experimentações que ocorrem dentro de instituições-modelo, como o Rooseum, e sua aplicação para um campo mais $\operatorname{amplo}^{7}$ (ESCHE, 2011). Nesse sentido, podemos considerar também o exemplo do

\footnotetext{
${ }^{7}$ I think it was a model, but that's not to say that it was not a real dream of a larger audience. But that dream is a dream, and it's important to have a certain degree of patience. If you look at the important exhibitions that were made, say, in the post-war period, very few of them that were successful at the time. Significant projects have generally been unpopular, even the intellectual community didn't necessarily embrace them. If you look at the reviews for the Harald Szeemann-exhibition When attitudes become form in 1969, you will see a picture which is a travesty of its significance now. People were simply writing it off as irrelevant. So how do you accommodate that in directing an institution today? In a sense your ambition is to try that dream of a larger audience, to try and have that kind of impact, and at the same time you know it's basically setting yourself up for unpopularity, probably. We really hoped and genuinely wanted that what we did at Rooseum would be effective. In hindsight we realize it was actually a model, a way of thinking about an institution in a place like Malmö, its relationship to an art community and to a particular kind of architecture. I think that institutional experimentalism or whatever you call it, have been important in how institutions like the Tate, or even the Pompidou and certainly now Reina Sofia in Madrid have developed certain elements of their program: it has increased the space for
} 
MACBA, uma instituição de grande porte que, como veremos mais detalhadamente, assume um programa experimental.

Outro aspecto importante ressaltado por Esche (2011) diz respeito às dificuldades encontradas pelo Rooseum para desenvolver seus projetos, que advinham de conflitos políticos entre partidos da cidade. Ele explica que o centro de arte havia se estabelecido durante o período em que o partido conservador Moderaterna estava no poder em Malmö, gestão durante o qual foi à falência, tendo sido recuperado pelos social-democratas que o sucederam, que, no entanto, nunca conseguiram aceitar o fato de a instituição ter sido criada por seus oponentes. Desse modo, de acordo com Esche (2011), a instituição esteve de alguma forma condenada pelo campo político independentemente do que ali fosse realizado, devido a essa história em particular. O Rooseum foi fechado em 2006 e, em 2009, foi aberta, em suas dependências, uma filial do moderna Museet de Estocolmo.

\subsection{KUNSTVEREIN MUNIQUE}

Aqui, abordamos os projetos realizados na Kunstverein de Munique durante o período em que Maria Lind dirigiu a instituição, de 2002 a 2004. Seu programa foi montado junto a uma equipe de curadores formada por Sören Grammel, Katharina Schlieben, Ana Paula Cohen, Judith Schwarzbart, Tessa Praun e Julienne Lorz (LIND, 2013). A diretora explica como as kunstverein, que consistem basicamente em associações de arte, têm, desde o fim da Segunda Guerra, atuado como espaços de experimentação para diferentes tipos de artistas, curadores e diretores, de modo que, em Munique, sua equipe buscou montar um programa que refletisse esse legado (LIND, 2013).

Entre os projetos organizados durante a gestão de Lind, vale destacar, primeiramente, o Sputnik, realizado em 2002, para o qual a instituição convidou quinze profissionais, entre eles artistas, críticos e curadores, para atuarem como "Sputniks" (“companheiro de viagem", em russo). Sendo assim, além de acompanhar a equipe curatorial da Kunstverein em suas viagens, a esses profissionais foi solicitado que pensassem diferentes projetos para a instituição (LIND, 2011). Ao destacar a preocupação de Lind com o tempo, ritmo e diferentes velocidades das atividades dentro do programa da Kunstverein, Paul O’Neill (2011) assinala como Sputnik atuou como um meio de desenvolver relações mais vagarosas, contínuas de longo prazo com artistas, curadores, escritores e profissionais culturais. Dentre os projetos 
realizados no contexto do projeto, a diretora destaca a ação de Apolonija Šušteršič sobre o lobby da instituição, a primeira interface entre o Kunstverein e o público. Assim, Šušteršič redesenhou esse ambiente de entrada do prédio, transformando-o em um espaço social e de trabalho multifunctional (LIND, 2011). De modo a ativar possibilidades mais contínuas para um espaço até então subutilizado, foram introduzidas ali cadeiras confortáveis e mesas para os visitantes, bem como um café e uma estação de trabalho para a equipe curatorial da instituição, de modo que suas funções administrativas fossem compartilhadas com o público (VOORHIES, 2016). De acordo com Lind (2011), esse projeto específico foi o que teve maior impacto sobre o cotidiano da instituição, de modo que tornou o espaço mais convidativo, confortável e flexível do que costumava ser. Também várias palestras, exibições e conversas passaram a ser realizados ali. Para James Voorhies (2016), tal proposta exemplifica o desejo do Novo Institucionalismo em redefinir estruturalmente a exposição de arte contemporânea e sua relação com o público, por meio da ruptura com um tempo de duração fixo para atividades específicas e da criação de variados ritmos de experiência e produção de arte.

Em 2003, foi realizado o projeto Totally Motivated: A Socio-cultural Manoeuvre, uma colaboração entre artistas e um grupo de cinco curadores: Maria Lind, Katharina Schlieben, Tessa Praun, Ana Paula Cohen e Søren Grammel (LIND, 2011). A ideia do projeto foi realizar algo coletivamente, e os curadores se interessaram pelo campo da cultura amadora e arte não-profissional, e, a partir disso, convidaram um grupo de artistas para participar do projeto (LIND, 2011). A diretora conta como todos os curadores participaram da seleção dos artistas e todo o grupo de curadores e artistas se reuniu na Kunstverein anteriormente à exposição. No espaço expositivo, a artista Carla Zaccagnini fez um enorme desenho de grafite sobre papel, que cobriu todo o Segundo andar do prédio. Já Michel Beutler projetou um teto feito de palha e madeira, de modo que, ao acrescentar fabricações ou elementos feitos de materiais modestos como esses a estruturas preexistentes, o artista busca alterar radicalmente a percepção do espaço em questão (CCS BARD, 2008). É importante destacar, de acordo com Lind (2011), como os artistas foram, de certa forma, responsáveis pelo design da exposição de modo geral, porém sempre em discussão com os curadores.

Como pudemos observar, o trabalho colaborativo entre artistas e curadores é distintivo nos projetos realizados sob a direção de Maria Lind na Kunstverein de Munique. A diretora destaca que buscou, com o programa da instituição, ir além da simples exibição da arte, de modo que as etapas que lhe são anteriores e posteriores são igualmente importantes, senão mais importantes, diferentemente do que tradicionalmente ocorre nas instituições de arte 
(LIND, 2011). Em um artigo para a Artforum, de 2009, Lind afirma que imagina a curadoria como uma maneira de pensar em termos de interconexões: articular objetos, imagens, processos, pessoas, locais, histórias e discursos no espaço físico como um catalisador ativo, gerando reviravoltas, desvios e tensões. Para a curadora, trata-se de uma abordagem curatorial que deve muito às práticas site-specific, e ainda mais a trabalhos sensíveis ao contexto e várias tradições de crítica institucional, cada uma delas encorajando a pensar a partir da obra, com a obra, mas também longe dela e contra ela ${ }^{8}$ (LIND, 2009).

\subsection{BASIS VOOR ACTUELE KUNST (BAK)}

O Basis voor Actuele Kunst (BAK) foi fundado em 2003, pela curadora Maria Hlavajova, para funcionar como um espaço para a arte, conhecimento e ativismo. Sua sede é ancorada em Utrecht, na Holanda, uma cidade investida nos campos da educação, conhecimento e experimentação, valores com os quais o BAK amplamente se identifica. $\mathrm{O}$ centro de arte tem como missão principal advogar pelo papel crítico e dinâmico da arte na sociedade, encarando-a como forma de conhecimento ativo acerca de urgentes questões sociais e políticas da contemporaneidade. É definido também como um espaço de interlocução entre vários públicos, partindo de preocupações compartilhadas a fim de negociar o conceito de um futuro comum por meio da imaginação artística, rigor intelectual e engajamento cívico. A instituição ainda se compromete ao aprendizado e à educação, bem como à experimentação artística, teórica e política, além investigar acerca de novos métodos e práticas de colaboração e troca (BAK, s.d).

Seus programas, no que diz respeito às áreas de educação, exposições e publicações, acompanham um tema de pesquisa específico e de longo prazo que é periodicamente alterado, e com base no qual são realizados painéis de discussão, palestras, workshops, módulos educativos em colaboração com academias de arte, universidades, escolas e outras comunidades, conferências, exposições e publicações. O formato assumido pelo programa é determinado de acordo com as necessidades de cada projeto de pesquisa e nenhuma atividade do programa se sobrepõe à outra, de modo que todas são consideradas espaços para reflexão e

\footnotetext{
${ }^{8}$ Today I imagine curating as a way of thinking in terms of interconnections: linking objects, images, processes, people, locations, histories, and discourses in physical space like an active catalyst, generating twists, turns, and tensions. This is a curatorial approach that owes much to site-specific practices, and even more to contextsensitive work and various traditions of institutional critique-each encouraging you to think from the artwork, with it, but also away from it and against it (LIND, 2009).
} 
troca de conhecimento, com o objetivo de oferecer meios de mobilizar ideias, encorajar discussões, motivar colaborações interdisciplinares e inspirar ação (BAK, s.d).

Maria Hlavajova (2015) conta como, antes de sua inauguração, a equipe do BAK passou um longo tempo reunida com vários profissionais do contexto de arte internacional como artistas, teóricos e curadores, refletindo em torno da questão do que seria uma instituição ideal na contemporaneidade, capaz de responder adequadamente aos desafios colocados por práticas artísticas contemporâneas, as quais estariam, por sua vez, em fluxo constante. A ideia foi evitar que a instituição se assentasse em uma zona de conforto de autoconfiança e conformidade. De acordo ela, o BAK regularmente incorpora projetos autorreflexivos, sempre questionando o que é necessário para que seja possível reivindicar uma posição como instituição crítica, experimental e disposta a correr riscos. A diretora cita, como exemplo, o projeto Knowledge Production (Practices in Contemporary Art), realizado em 2006, e a subsequente publicação On Knowledge Production. A Critical Reader in Contemporary Art, em 2008, que objetivou promover um fórum de discussão, partindo de termos corriqueiros no campo da arte e muitas vezes usados com desatenção, como "pesquisa artística" e "produção de conhecimento", os quais acabam sendo, muitas vezes, envoltos pelas ideologias do mercado e do espetáculo. Foi então realizada uma tentativa de discutir como seria possível a manutenção do potencial crítico do discurso da prática artística-comoconhecimento sob essas circunstâncias (HLAVAJOVA, 2015).

Quanto aos projetos educativos, o BAK trabalha regularmente junto à Universidade de Amsterdã, a Universidade de Utrecht, a Hogeschool voor de Kunsten, também em Utrecht, entre outras instituições acadêmicas na Holanda e no exterior, como a Goldsmiths College de Londres e a Academy of Fine Arts de Viena. A diretora e outros membros da instituição, que lecionam em academias e universidades, empenham-se em difundir os conhecimentos gerados no BAK em diversos contextos educacionais (BAK, s.d). Destaca-se também o Learning Place, uma plataforma educacional que consiste em uma base por meio da qual os participantes podem interagir e realizar trocas com artistas, acadêmicos e ativistas que contribuem para os projetos da instituição (BAK, s.d). O centro de arte mantém também uma dimensão online ativa de seus programas, sob a forma de uma plataforma de conhecimento digital que disponibiliza seus conteúdos para o público em escala global (BAK, s.d).

Entre os projetos mais recentes desenvolvidos pelo BAK está Future Vocabularies, que a instituição define como um projeto multifacetado de pesquisa, educação, exposição e publicação de longo prazo, desdobrando-se durante o período entre 2014 e 2017. Ainda, 
Future Vocabularies dá continuidade a projetos passados, estabelecendo contato com artistas, teóricos e ativistas, de modo a postular trajetórias de pesquisa propositivas com relação a como pensar, com e por meio da arte, sobre algumas das questões mais urgentes que definem a contemporaneidade, tais como a subsistência de refugiados, a suportabilidade do planeta e o futuro da infraestrutura institucional. Os colaboradores do projeto acompanham a instituição e ajudam no desenvolvimento de sua agenda de atividades semestral (BAK, s.d). Com relação aos projetos anteriores, Future Vocabularies resultou de, bem como foi desenvolvido paralelamente à fase final de Former West, que se estendeu de 2008 a 2016. Esse também foi definido como um projeto multifacetado, ou, ainda, um projeto de investigação coletivo e nômade, que tomou forma por meio de uma série de congressos, exposições, publicações, plataformas educacionais e programas discursivos, realizados junto a instituições artísticas e educacionais internacionais (BAK, s.d). Sua temática partiu do questionamento acerca da situação do Ocidente após o fim da bipartição do mundo pela Guerra Fria. Tendo resultado em publicação homônima, Former West buscou unir teoria e prática de arte e política para esboçar uma cartografia do contemporâneo, bem como tentar intervir no presente por meio da articulação de alternativas propositivas à narrativa canônica do pós-1989. Nesse contexto, o projeto buscou estabelecer um prisma alternativo por meio do qual a arte pudesse ser vista, revista e recuperada (BAK, s.d). Hlavajova (2015) identifica as preocupações do BAK como ocupando uma intersecção entre práticas artísticas e movimentos na sociedade e na política, sendo que os temas para os projetos da instituição são definidos por meio do envolvimento de vários grupos de pessoas, como artistas, teóricos, cientistas sociais, curadores, entre outros (HLAVAJOVA, 2015).

Quanto à relação do $\mathrm{BAK}$ com o público, a diretora trata de estabelecer distinções entre os termos "público" e "audiência", de modo que, ao tratar do primeiro, tem em mente a noção de esfera pública, um espaço a ser preenchido com negociações a respeito de como viver juntos $^{9}$ (HLAVAJOVA, 2015). Ela explica que um diálogo acerca de preocupações públicas não pode ser realizado exclusivamente diante de objetos exibidos em galerias, de modo que outras maneiras precisam ser examinadas, e cabe à instituição de arte a responsabilidade por essa tarefa. Ela elenca os três tipos de público envolvidos com o BAK: o primeiro é formado pelos profissionais culturais, que participam do desenvolvimento e

\footnotetext{
${ }^{9}[\ldots]$ And I do not mean that "public" equals audience; I really have the notion of the public sphere in mind when I talk about this, a space between us that we fill with ongoing negotiations about how to live together (HLAVAJOVA, 2015).
} 
realização de projetos da instituição. O segundo é constituído por visitantes de exposições e atividades discursivas ali organizadas. O terceiro e mais remoto (física e geograficamente) tipo de público é formado por pessoas com as quais o BAK se comunica por meio de suas publicações, incluindo folhetos contendo informações importantes a respeito das questões principais de cada projeto, os quais são distribuídos gratuitamente para uma ampla rede de recipientes internacionalmente (HLAVAJOVA, 2015). Também são publicados, ao invés de catálogos de exposições, manuais críticos que servem, por meio de textos de artistas e teóricos, como plataformas paralelas para explorar ideias particulares. Outra forma de comunicação da instituição com esse público remoto se dá por meio de seu website, que inclui um arquivo de vídeo com todas as palestras, conferências, conversações e painéis de discussões lá realizados, além de referências como recomendações de leitura acerca dos assuntos com os quais o BAK está engajado, bem como outras informações de pesquisa. $\mathrm{O}$ quarto público assinalado por Hlavajova (2015) é formado por meio do discurso desenvolvido internacionalmente em torno do próprio BAK por meio de revisões e análises de seus projetos e abordagem institucional. A diretora nota as inevitáveis diferenças entre as formas de recepção com relação aos públicos remotos e os visitantes locais do BAK. No entanto, para ela, dado o tipo de trabalho com o qual a instituição se empenha, a noção de acesso a ideias e conhecimento articulado por meio de suas atividades é de muito maior importância do que a contagem de público dentro de seus limites físicos (HLAVAJOVA, 2015). A diretora assinala que não desconsidera a interação interpessoal e com o espaço que se dá nas visitas, entretanto, entende que os canais institucionais de comunicação não podem se resumir unicamente às exposições. Assim, palestras, conversas, publicações de vários tipos, a internet e a bologosfera são canais utilizados pela instituição não como espaços para divulgar o que fazem ou como forma de marketing, mas sim como canais por meio dos quais a equipe do BAK é capaz de divulgar conhecimento, ideias e proposições que possam ser utilizadas publicamente (HLAVAJOVA, 2015).

\subsection{PLATAFORM GARANTI}

O Centro de Arte Contemporânea Platform Garanti funcionou, entre 2001 e 2007, em um prédio localizado no movimentado distrito de Beyoğlu, em Istambul, que continha um arquivo de artistas, espaços para pesquisa e palestras, o Programa de Residência de Istambul, e, no nível da rua, uma galeria. O Centro de Arte definia-se, de acordo com seu blog, como 
um catalisador para a disseminação, pesquisa e prática de arte contemporânea na cidade, além de atuar como um ponto de encontro para trocas entre artistas, curadores e críticos. Dirigido pelo curador Vasif Kortum, o Centro recebeu, através de seu Programa de Residência, artistas provenientes de países nos quais a cena de arte contemporânea estava em formação, porém não possuíam instituições de arte suficientes ou estruturas de financiamento para oferecer-lhes suporte (PLATFORM GARANTI, 2000). Ainda, o Platform Garanti contava com um arquivo de trabalhos de mais de 140 artistas turcos, o maior conteúdo de publicações de arte de Istambul, além da edição de publicações distribuídas internacionalmente, realização de exposições, conversas, palestras e conferências.

A instituição foi fundada com o apoio do Banco Otomano, que depois foi incorporado pelo Banco Garanti, instituição à qual seu prédio passou a pertencer. Seu programa de residência era apoiado por agências de financiamento nacionais e regionais de diversos países, como Holanda, Bélgica, Suécia, País Basco, Noruega, Suíça, Grécia e Finlândia. Ainda, o Centro contou com a doação de uma bolsa de três anos pela American Center Foundation, que permitiu que fossem convidados para residências três artistas do Sudeste Europeu, Sudeste Mediterrâneo e Oeste da Ásia entre 2004 e 2006. Também foi oferecida, por meio de uma subvenção proveniente da Open Society Institute, para artistas da região do Cáucaso, a oportunidade de passar dois meses em Istambul. Outra parceria, com o programa Bacyard Residency, apoiado pelo Nordic Council of Ministers, possibilitou a recepção de quatro artistas de países do Sudeste Europeu entre setembro de 2006 e junho de 2007. Entre 2004 e 2005, a Platform Garanti funcionou como base para o desenvolvimento da nona Bienal Internacional de Istambul e recebeu seis artistas sob o programa de residência para participar da exposição (PLATFORM GARANTI, 2000).

No final de 2007, o Centro de Arte deu uma pausa em seu programa expositivo, e, em 2010, formalmente encerrou as atividades sob o nome Platform Garanti Contemporary Art Center. Em 2008, foram iniciadas renovações tanto no prédio do Platform Garanti, como na antiga sede do Banco Otomano, no bairro de Gálata, de modo a dar origem ao novo centro cultural SALT, que passou a englobar as atividades do Platform Garanti, da Galeria Garanti e do Centro de Pesquisa e Arquivos do Banco Otomano, ao qual os documentos acumulados pelo Platform Garanti foram incorporados (PLATFORM GARANTI, 2000). 


\subsection{PRINCIPAIS CARACTERÍSTICAS DOS PROGRAMAS OBSERVADOS}

Ao conhecer as principais diretrizes dos programas propostos em determinadas instituições experimentais, durante a gestão de certos diretores, foi possível notar características distintivas de cada programa, bem como elementos que eles mantêm em comum. Sobre o Rooseum, destaca-se a intenção de Charles Esche de promover um espaço que se dividisse entre as funções de centro comunitário, laboratório e academia, uma instituição responsiva às mudanças sociais e às questões que interessam à sua comunidade, além da importância de se estar aberta à experimentação, ao questionamento e à descoberta tanto pelos artistas como pelos visitantes, além de promover a pesquisa e produção de conhecimento por meio de convênios com universidades e instituições de ensino. Ao atentarmo-nos para os projetos realizados na Kunstverein de Munique durante a gestão de Maria Lind, uma das características que se sobressaiu foi a intenção da instituição em promover o trabalho colaborativo, bem como o estabelecimento de relações horizontais e contínuas entre artistas, curadores e outros agentes culturais, rompendo com um tempo de duração fixo para atividades específicas e possibilitando a criação de variados ritmos de experiência e produção de arte. No caso do BAK, destaca-se a realização de projetos multifacetados de pesquisa de longo prazo, em torno dos quais revolvem atividades como painéis de discussão, palestras, workshops, módulos educativos em colaboração com academias de arte, universidades, escolas e outras comunidades, conferências, exposições e publicações que objetivam tratar, por meio da arte, de questões urgentes à contemporaneidade. Outro elemento importante a ser ressaltado é a preocupação da instituição em estabelecer relações também com o público remoto, por meio de uma plataforma digital em que disponibiliza amplo conteúdo de seus programas. Quanto ao Platform Garanti, notou-se a importância do centro de arte, por meio de seu programa de residências e da manutenção de um importante arquivo, para o fomento à pesquisa e a prática artística na Turquia, bem como o amparo a artistas cujos países não possuíam estruturas abrangentes de financiamento. De maneira geral, foram observadas algumas preocupações que permeiam todas instituições citadas. Entre elas, está a intenção em abordar temas e questões relevantes a seus contextos políticos e econômicos de diferentes maneiras, como por meio de seminários, debates, cursos, oficinas, exposições e publicações, entre outras atividades, de modo que o formato expositivo não é privilegiado, mas sim integra um processo de reflexão e construção de conhecimento. A relação do público e da comunidade com as instituições também é crucial para a grande maioria desses espaços, de modo que eles 
buscam tanto responder às suas demandas, como recebê-los como participantes ativos em seus processos e atividades. Nesse contexto, existe a tendência de que essas instituições recebam um menor número de visitantes gerais, ao passo que elas se tornam mais passíveis de estabelecer relações significativas e contínuas com os membros de sua comunidade, uma vez que as atividades não são propostas de modo pontual, mas como um processo em que o público deve estar envolvido. Conforme já pontuado, é relevante também o desenvolvimento dessas empreitadas como referências para iniciativas que possam ser aplicadas a instituições de maior porte e visibilidade. Ainda no que tange ao estabelecimento de vínculos entre essas instituições e seu público, vemos que as publicações desempenham importante papel, ao buscar ampliar o alcance das discussões e desdobramentos resultantes das atividades realizadas em seus espaços, bem como por meio de entrevistas e ensaios, para além dos catálogos de exposições, que abordam questões prementes no panorama contemporâneo. Em suma, ao tratarmos de experimentações institucionais ou instituições experimentais, fazemos referência a uma preocupação de museus e centros de arte em funcionarem para além de espaços expositivos, de modo que possam atuar como laboratórios onde artistas desenvolvam suas práticas, fomentar a pesquisa, atuando junto à academia, em um processo de trocas. Considera-se que essas instituições, de modo geral, concebem o público como agente de seus processos, por meio da participação e da colaboração, à medida que buscam colocar os interesses do público à frente de interesses comerciais.

Ao observar os impasses políticos enfrentados pelo Rooseum, pudemos começar a perceber algumas das dificuldades enfrentadas por diversas instituições experimentais, principalmente a partir dos anos dois mil. Nesse sentido, Nina Montmann (2007) ressalta como alguns museus e centros de arte, tais quais a Kunstwerke Berlim, o Museu de Arte Contemporânea de Oslo, o Centro de Arte Contemporânea em Vilnius, a Kunsthalle de Helsinki e o Instituto Nórdico para Arte Contemporânea (NIFCA) passaram por posteriores mudanças, bem como por redirecionamentos de cursos políticos, após a experiência do Novo Institucionalismo. O Museu de Arte Contemporânea de Oslo fundiu-se a outros museus nacionais da cidade sob a administração do Museu Nacional para Arte Contemporânea, Arquitetura e Design, enquanto o Centro de Arte Contemporânea em Vilnius sofreu diversos cortes orçamentários. Além disso, diversos curadores e diretores foram substituídos, o que ocasionou grande impacto na abordagem programática das instituições. No caso do NIFCA, a própria instituição foi fechada, em 2007. Também a esse respeito, Lind (2016) nota como as instituições experimentais tiveram dificuldade em dar continuidade a seus programas, já que 
encontraram maior dificuldade em obter financiamento e apoio por parte de seus conselhos diretores.

Para Montmann (2007), as dificuldades enfrentadas pelas instituições experimentais se devem ao fato de que espaços de criticidade não são bem quistos em meio à "virada corporativa" no cenário institucional. A autora assinala também que tal fenômeno não afeta apenas as grandes instituições, administradas como marcas globais, como no caso Guggenheim (exemplo claro, para Montmann, de como uma instituição é concebida e dirigida por políticos e patrocinadores), mas também afetaria instituições de médio e pequeno porte, que deveriam ser experimentais, mas se veem forçadas a adentrar programas curatoriais similares aos das instituições maiores e melhor estabelecidas.

Por outro lado, Alex Farquharson (2016) especula se o fato de várias instituições acabarem por deixar de lado as experimentações institucionais, muitas vezes retornando aos "velhos hábitos", dever-se-ia ao fato de tais práticas estarem mais ligadas às figuras de diretores específicos, que tratam de aplicar mudanças dentro das instituições, do que à construção de uma "cultura institucional", de modo que diretores posteriores poderiam acabar por abandonar as novas diretrizes estabelecidas. Trata-se, pois, de uma das questões que buscamos tatear por meio do estudo de caso das gestões desenvolvidas no MACBA, no capítulo seguinte.

Outra questão importante é levantada por James Voorhies (2016) que, à medida que considera o curador como organizador e fonte significativa de conteúdo crítico, indaga acerca da possibilidade de manutenção dessa postura crítica por parte dos curadores, ou, no presente contexto, os diretores das instituições, em meio à globalização da arte contemporânea, indústria capaz de reduzir a potência da crítica por meio da absorção e da necessidade de produzir experiências cada vez maiores e mais espetaculares, que gerem capital econômico e cultural $^{10}$ (VOORHIES, 2016).

Nesse cenário, Voorhies (2016) defende a necessidade de uma continuidade quanto ao questionamento acerca da viabilidade de formas críticas de arte, em direção a novas possibilidades. Já Charles Esche (2011), como vimos, ressalta como não se deve esperar que uma instituição experimental seja massivamente popular, e que patrocinadores amplamente abracem suas propostas. Desse modo, para o curador, é inverossímil esperar que o Novo

\footnotetext{
${ }^{10}$ With an emphasis on the curator as the organizer and a significant source of critical content and motivation, the responsibility of the institution to police its own behaviors and borders becomes even more urgent [...] Indeed a critical attitude faces a fugitive position in the midst of globalized contemporary art, an industry that has the potential to reduce the potency of critique through absorption and the need to produce greater and more spetacular experiences that generate economic and cultural capital (VOORHIES, 2016).
} 
Insitucionalismo fosse se transformar em uma nova ideologia, capaz de tomar conta das instituições, de modo a substituir suas "antigas" ideologias. Porém, o mais importante, para o curador, é a possibilidade de que essas experimentações surtam efeitos em instituições maiores (ESCHE, 2011). Nesse sentido, James Voorhies (2016) observa como, apesar de o termo não ter emplacado, as atividades do Novo Institucionalismo ainda assim integram o cenário geral da arte contemporânea atual: de forma dispersa e pulverizada, essas ainda existem em grandes e pequenas instituições, e em iniciativas de artistas e curadores mundo afora. Para Voorhies (2016), exemplo disso é a inserção, em programas de museus de grande porte, de modos alternativos de exibição.

Diante das dificuldades aqui elencadas, enfrentadas por instituições que propuseram experimentações institucionais, principalmente no início dos anos dois mil, surge o interesse em investigar acerca da realização de atividades nesse sentido na atualidade. Tomamos como objeto de estudo, como pode ser visto no próximo capítulo, o caso do MACBA, a fim de detectar e mapear propostas e programas em direção à promoção de instituições críticas, autorreflexivas e reativas quanto aos interesses e necessidades de suas comunidades, em detrimento de modelos guiados pelos interesses do mercado e do turismo cultural, baseados no entretenimento e na atração de público. 


\section{EXPERIMENTAÇÕES INSTITUCIONAIS NO MUSEU DE ARTE CONTEMPORÂNEA DE BARCELONA (MACBA)}

A escolha pelo MACBA como objeto principal de estudo para este trabalho surge a partir do interesse sobre as atividades realizadas no Museu durante a gestão de Manuel BorjaVillel, entre 1998 e 2007, que, conforme é detalhado ao longo deste capítulo, foi marcada por uma estruturação das atividades do museu e a proposição de um programa institucional consistente e coeso, reativo ao contexto político local e global da época e às urgências de sua comunidade, preocupado em promover alternativas às narrativas canônicas da História da Arte, o que o diretor de Programas Públicos dessa gestão, Jorge Ribalta, chamou de experimentos em uma Nova Institucionalidade. Diante das realizações de Borja-Villel e sua equipe, que coexistiram com as outras experimentações institucionais comentadas anteriormente, o presente trabalho busca mapear a presença de propostas do tipo nos exercícios dos diretores seguintes, de modo que possamos identificar a continuidade ou não de experimentações institucionais no MACBA, bem como possíveis dificuldades encontradas ao longo dos processos de gestão. Nesse contexto, procura-se testar a suposição de que figuras específicas de liderança, no caso os diretores, são cruciais para a implementação e sustentação das propostas diante dos diversos atores que coexistem dentro das estruturas institucionais, como Conselhos, patrocinadores, fundações, etc.

Pretendemos, em primeiro lugar, compreender o contexto e objetivos que circundam a concepção do projeto do MACBA, bem como visualizar a parceria público-privada sobre a qual o Museu está baseado, por meio do Consórcio MACBA. Em seguida, passamos a analisar as características das gestões de cada um dos diretores que passaram pela instituição, seus discursos e programas propostos. Assim, começamos pela de Daniel Giralt-Miracle, que teve seu fim antes da inauguração do Museu, seguida das de Miquel Molins (1995-1998), Manuel J. Borja-Villel (1998-2007), Bartomeu Marí (2008-2015) e Ferran Barenblit (desde 2015). Cabe destacar que as fontes utilizadas são essencialmente oficiais, consultadas principalmente durante residência de pesquisa realizada no Centro de Estudos e Documentação do MACBA, em que foi disponibilizado acesso a materiais físicos e digitalizados de seu arquivo, como registros de atividades realizadas a partir de 1995 e publicações do Museu, além de livros, catálogos e publicações presentes na Biblioteca MACBA. Também foram consideradas entrevistas dadas pelos diretores a jornais e revistas a respeito de suas propostas para o MACBA, além da documentação das atividades realizadas no Museu, desde 1999, presentes no site da instituição (www.macba.cat). Sendo assim, 
pretendemos localizar, tanto nos discursos de cada diretor, como nos registros de atividades realizadas em cada gestão, indicativos de propostas no sentido das experimentações institucionais em questão neste trabalho, a fim de rastreá-las até os dias atuais, tendo em vista que nos baseamos na perspectiva da própria instituição e de seus profissionais.

\section{Contexto de fundação do MACBA}

O MACBA abriu suas portas no dia 28 de novembro de 1995 na cidade de Barcelona, mais precisamente no bairro El Raval, que integra o distrito da Cidade Velha. De acordo com a própria instituição, o Museu se consolidou internacionalmente como um modelo na arte contemporânea, graças a dois motivos principais: de um lado, devido ao considerável crescimento de sua coleção, a qual permitiria traçar um percurso através de algumas das referências artísticas de nosso tempo; de outro, por meio do desenvolvimento de linhas de trabalho baseadas na assunção de riscos e na vontade de atuar como laboratório, elementos que teriam posicionado o MACBA como um centro chave no âmbito da pesquisa e na geração de novas dinâmicas para a análise e a reflexão sobre a atividade artística (MACBA, s.d).

Seus antecedentes remontam à 1959, ano em que o crítico de arte Alexandre Cirici Pellicer defendeu a necessidade de se criar um museu de arte contemporânea na cidade. Cirici, junto a Cesáreo Rodríguez-Aguilera e outras personalidades, começaram a reunir uma coleção que serviria como base para o futuro museu, por meio da organização de diversas exposições. No entanto, a empreitada não foi adiante e, em 1963, parte dos fundos reunidos foram destinados ao Museu Víctor Balaguer de Vilanova i la Geltrú (MACBA, s.d). Já em 1985, a ideia de criação de um museu de arte contemporânea é recuperada por Joan Rigol, conselheiro de cultura da Generalidade da Catalunha, e compartilhada com os responsáveis municipais da Área de Cultura, encabeçada por Pep Subirós. Firma-se então um Pacto Cultural, promovido por Rigol e consentido por ambas as administrações, e que ratificou a criação de um Consórcio constituído pela Generalidade da Catalunha, sistema institucional em que se organiza politicamente o autogoverno da Catalunha (formado pelo Parlamento, Conselho Executivo e a Presidência da Generalidade), e o Ajuntamento (Prefeitura) de Barcelona, responsável pela administração municipal, para criar um museu na antiga Casa de la Caritat. A ideia de Rigol, conforme ele explicita do documentário MACBA: la derecha, la izquierda y los ricos (2013), era borrar as fronteiras entre direitas e esquerdas, bem como entre a cultura mais acadêmica, de resistência, na qual o Instituto de Estudos Catalães estava 
muito arraigado, com uma cultura de uma literatura muito mais ampla e aberta. Porém, a substituição de Rigol poucos meses depois interrompeu temporariamente o desenvolvimento do projeto. Já em 1986, a Prefeitura de Barcelona, agora com Pasqual Maragall à frente, deu andamento ao projeto, encarregando o arquiteto norte-americano Richard Meier da construção da sede do novo museu (MACBA, s.d). Em 1987, é formada a Fundação Museu de Arte Contemporânea de Barcelona, o que representa a incorporação da iniciativa privada ao projeto. A Fundação firma um contrato com as 33 empresas que a integravam, à época, para que contribuíssem com 25 milhões de pesetas cada uma. Dessa forma, o MACBA nasce, em abril de 1988, com base na consolidação do Consórcio do Museu de Arte Contemporânea de Barcelona, integrado pela Generalidade da Catalunha, a Prefeitura de Barcelona e a Fundação Museu de Arte Contemporânea de Barcelona. Vale notar que, futuramente, em 2007, o Ministério da Cultura é também incorporado ao Consórcio (MACBA, 1996).

Para Xavier Bru de Sala, diretor geral de promoção cultural da Generalidade entre 1989 e 1991, o MACBA surge na toada da inauguração do Reina Sofia, com seu caráter de Museu Nacional, inaugurado em 1986 (MACBA..., 2013). Leopoldo Rodés, presidente da Fundação MACBA de 1987 até seu falecimento, em 2015, explica que havia, antes do MACBA, a presença de importantes museus em Barcelona, como o da Ciutadella e o Museu de Arte Moderna da Catalunha, os quais não possuíam, no entanto, do ponto de vista das artes plásticas, manifestações claras (MACBA..., 2013). Para Pep Subirós, Rigol havia sido convencido de que algo que a Prefeitura não possuía, mas tinha intenções de fazer e que poderia atuar como uma bandeira da Generalidade seria justamente um museu de arte contemporânea (MACBA..., 2013). Daniel Giralt-Miracle assinala as diferentes posições de cada uma das instituições constituem o Consórcio MACBA: a prefeitura, que era progressista, a Generalidade, conservadora, e a Fundação, com seus membros endinheirados e inseridos no circuito do colecionismo privado das artes (MACBA..., 2013).

Quanto à coleção que passa a integrar o MACBA, essa advém de diversas fontes: obras adquiridas pela Fundação com recursos privados; obras de artistas catalães que integravam o fundo de arte da Generalidade da Catalunha, enriquecida com a incorporação da coleção Salvador Riera; o fundo de arte contemporânea do Ajuntamento de Barcelona, complementados com as obras das oficinas Art Triangle, realizados na antiga Casa de Caritat, futuro Centro de Cultura Contemporânea de Barcelona, em 1987 (MACBA, 1996). A princípio, quando desse período de gestação da Coleção, é realizada uma aproximação entre o MACBA e a Fundação "La Caixa”, de modo que se buscava estabelecer um acordo segundo o 
qual as duas instituições poderiam usufruir dos fundos de suas coleções (ambas privadas) reciprocamente (MACBA..., 2013). Como veremos, essa tentativa de acordo gera desavenças que culminarão na renúncia de Miquel Molins do cargo de diretor, em 1998.

Em 1988, é nomeado o primeiro diretor do MACBA, o historiador e crítico de arte catalão Daniel Giralt-Miracle, sendo que o Museu é inaugurado publicamente no dia 28 de novembro de 1995 (MACBA, 1996).

Outro elemento a ser levado em consideração ao abordarmos o MACBA é sua localização: o bairro de Raval. A esse respeito, Jorge Ribalta (2004) explica como se trata de um bairro complexo, localizado no centro histórico de Barcelona, cenário de luta entre duas forças opostas, uma em direção à elitização e outra que diz respeito à diversidade e complexidade culturais do local, incrementada pela chegada de imigrantes de vários países. Quanto à elitização, Ribalta (2004) pontua como, a partir de meados dos anos oitenta, o poder municipal passou a promover a transformação social do bairro, constituído historicamente por uma população de classe trabalhadora e sub-proletária. Nesse contexto, as instituições artísticas e culturais, como universidades, teatros, centros de arte e o próprio MACBA, desenvolveram papel crucial em favor de tal transformação. Também algumas partes do centro histórico do Raval foram conquistadas por novas classes médias urbanas, o que se observou, de acordo com Ribalta (2004), com a abertura de um crescente número de lojas de roupas, livrarias, restaurantes, bares e casas noturnas. Ainda, para o autor, o aumento do custo de vida na região, que já havia sido o mais barato da cidade, passou a favorecer a chegada de novo capital (RIBALTA, 2004). Por outro lado, o Raval tornou-se mais complexo culturalmente com a chegada de novos imigrantes, tendo passado a abrigar comunidades paquistanesas, norte-africanas (principalmente marroquinas) e algumas não ocidentais relativamente grandes, como filipinas, do leste Europeu e da América Latina. Tais comunidades, explica Ribalta (2004), são majoritariamente constituídas por pessoas pobres e ilegais, e passaram a demonstrar uma notável capacidade para crescer e reconquistar áreas do bairro por meio de economias informais. Diante dessa configuração, o poder municipal passou a desenvolver estratégias urbanas voltadas para reforçar a segurança, bem como a limpeza da zona para as novas classes médias e o turismo (RIBALTA, 2004). Tendo em vista as condições que afetam o bairro em que o MACBA está situado, a capacidade de estabelecimento de uma relação entre a instituição e suas comunidades de entorno é mais um elemento a ser levado em consideração ao observarmos os programas propostos pelo Museu. 
A partir daqui, enfatizamos o período de atuação de cada diretor no MACBA, a fim de que possamos compreender o contexto político e econômico que circunda cada gestão, bem como as propostas, discursos e as atividades desenvolvidas durante cada uma delas, tendo como referência os elementos característicos, de modo geral, das instituições experimentais abordadas neste trabalho:

\subsection{A GESTÃO DE DANIEL GIRALT-MIRACLE (1988-1994)}

Como vimos, Giralt-Miracle assume a direção do Museu em 1988. No ano seguinte, começam a ser delineadas as primeiras ideias fundamentais acerca de seu projeto de museu. Em 1990, Jean Louis Froment, criador do Centro de Artes Plásticas Contemporâneas de Bordeaux (atualmente Museu de Arte Contemporânea de Bordeaux), é nomeado assessor da equipe diretiva do Museu, encarregado dos projetos museológico e museográfico (MACBA, 1996). No ano seguinte, Froment, junto à Giralt-Miracle, apresentam um primeiro projeto, que abarca três níveis, correspondentes aos três andares do Museu: artistas contemporâneos de prestígio, artistas em processo de consolidação e artistas experimentais (MACBA, 1996). Diante do projeto, emerge um debate público acerca de qual período artístico deveria ser abarcado pela coleção do Museu. Nesse contexto, o diretor geral de Patrimônio da Generalidade, Eduard Carbonell, defende que o MACBA se encarregue da arte correspondente ao período que vai de 1939 a 1980. Por outro lado, a Fundação MACBA defende que a arte desse período já estaria representada principalmente no Museu Nacional de Arte da Catalunha (MNAC). Em 1992, a Junta de Museus decide que as coleções do MACBA comecem a partir da arte catalã de 1940. A Fundação reitera seu apoio ao projeto de Froment, enquanto ao Prefeitura e a Generalidade anunciam um acordo de que as coleções do Museu começariam a partir do pós-guerra (MACBA, 1996). Em outubro do mesmo ano, Froment e Giralt-Miracle apresentam seu projeto definitivo ao Consórcio do MACBA, e que consiste em três coleções: histórica (1945-1980), contemporânea (1980-1990) e prospectiva (jovens artistas). No entanto, a aprovação definitiva do projeto é adiada pelo Consórcio, de modo que Prefeitura e Generalidade incumbem Giralt-Miracle de desenvolver um projeto alternativo ao realizado junto à Froment. Cabe destacar que, nesse contexto, o próprio cargo de diretor ainda estava em jogo, de modo que a Generalidade e a Prefeitura queriam Giralt-Miracle no cargo, enquanto a Fundação votara por Froment, de modo que Giralt-Miracle acabou por ser escolhido, no entanto, em meio a tensões. A questão é que Generalidade e Prefeitura passaram a projetar, junto à figura de Giralt-Miracle, o desenvolvimento de um projeto nacional e 
localista de Museu, enquanto a Fundação apostava, com Froment, em um projeto internacional e de internacionalização de artistas locais, como era o caso de Miquel Barceló (MACBA..., 2013). Em 1993, ainda não se havia chegado a um acordo quanto ao projeto para o MACBA, e Giralt-Miracle coloca incertezas quanto a sua permanência no cargo de diretor, reivindicando a resolução da situação de desacordo institucional. Também entram em questão a redefinição dos estatutos do Consórcio e a delimitação dos papeis da Fundação MACBA e do diretor do Museu. Como resultado dessas tensões, em 5 de outubro de 1994, Daniel GiraltMiracle renuncia ao cargo de diretor do MACBA, de modo que, em janeiro do ano seguinte, o historiador de arte e professor da Universidade Autônoma de Barcelona, Miquel Molins, assume o cargo, o que implica em uma reforma do estatuto para dotar o diretor do Museu de autoridade executiva (MACBA, 1996).

\subsection{A GESTÃO DE MIQUEL MOLINS (1995-1998)}

No texto Gestació i creació d'un projecte: el MACBA. Un somni que va costar de fer realitat: un museu per a l'art contemporani, Daniel Giralt-Miracle (2007) conta como, na abertura de portas do Museu, em 1995, foram apresentadas obras representativas da coleção, de artistas como Richard Long, Àngel Ferrant, Donald Judd, Susana Solano, Jorge Oteiza, Mario Merz, Pistoletto, etc., exposição que teve boa acolhida pelo público e pela crítica. No entanto, Giralt-Miracle (2007) nota como, até então, a linha museológica da instituição ainda não havia sido definida, de modo que as partes do Consórcio permaneciam firmes em suas posições. Ele ressalta como Molins defendia uma coleção que buscava articular pontos de ancoragem e cruzamento que permitissem estabelecer ligações significativas entre o panorama artístico catalão e espanhol e as tendências estrangeiras que mais haviam influído na arte contemporânea na Catalunha. E, dividindo a coleção entre três seções cronológicas, "histórica", "atual" e "prospectiva", buscava-se um diálogo constante entre o local e o universal (GIRALT-MIRACLE, 2007). Para Giralt-Miracle (2007), Molins conseguiu, com sua proposta, colocar ordem nas coleções procedentes da Prefeitura de Barcelona e da Generalidade da Catalunha, embora tenha encontrado dificuldades ao lidar com a Fundação MACBA. Isso porque, explica Giralt-Miracle (2007), Molins reivindicava poder comprar obras para o Museu que lhe permitissem completar seu discurso, o que a Fundação não lhe permitira fazer. Aqui volta a ser evidenciada, assim como vimos com Giralt-Miracle, a dificuldade dos diretores do MACBA em efetivar suas propostas diante de possíveis conflitos de interesses com as estruturas decisórias da instituição. 
Quanto ao discurso de Molins, que guiaria suas propostas para o MACBA, no catálogo el museu pren forma, são citados trechos de uma entrevista de Miquel Molins à Zeneida Sardà para a Revista Sierra D'Or, em dezembro de 1995, seu primeiro ano como diretor do MACBA. Quando perguntado sobre o que se caracterizaria como um museu de arte contemporânea, Molins (1996) responde que aquela se tratava de uma pergunta em debate na época, já que ainda não haviam sido resolvidos os problemas derivados da relação entre o museu e o Sistema de Mercado, e nem sequer os efeitos da cultura do espetáculo: as estratégias dos meios de comunicação de massa, a ênfase no espetáculo e no entretenimento, o culto à celebridade e a produção em massa. Desse modo, para o diretor, o MACBA partia de uma crise dos modelos fundamentais da cultura do século $\mathrm{XX}$, bem como das mudanças sofridas pela sociedade (MOLINS, 1996). Molins (1996) também assinala a necessidade de que o MACBA fosse dotado de espírito crítico, o que implicava no constante questionamento dos discursos e mecanismos do Museu. Ainda, para ele, a instituição deveria ser capaz de propor discursos e ferramentas de análise conceitual para confrontar os problemas da criação contemporânea, bem como abordar a relação entre a obra e o espectador (MOLINS, 1996).

Sendo assim, Molins (1996) estabelece, à época, algumas diretrizes a serem seguidas pelo MACBA, e que incluíam o objetivo de formar, no sentido da busca pelo desfrute e o conhecimento da arte contemporânea, e a formação do gosto e da sensibilidade dos visitantes. Nesse sentido, o diretor fala de uma função pedagógica do museu, que consistiria também, em suas palavras, em "civilizar" e "humanizar", "no sentido mais amplo do termo", dando às pessoas a capacidade de julgar acerca do que veem (MOLINS, 1996). Ainda, para ele o MACBA não se limitaria a explicar a história da arte contemporânea da segunda metade do século XXI, mas sim objetivaria incidir na realidade de seu entorno e esforçar-se a integrar o espectador nesse processo de exploração e interrogação da realidade (MOLINS, 1996).

Outra das diretrizes dizia respeito à aquisição, conservação e difusão das obras de arte contemporânea, que Molins (1996) considera funções básicas e ao mesmo tempo convencionais, além de que o Museu deveria dar atenção especial aos artistas catalães ou com trabalhos relacionados à Catalunha. Por fim, o diretor ressalta a importância do investigar, em referência à necessidade de constituição de fundos bibliográficos e documentais que facilitassem o conhecimento e a difusão da arte contemporânea. Tal esforço, para Molins (1996), já se verificava, à época, na existência de uma Biblioteca bem equipada e no objetivo de criar um vigoroso Centro de Documentação (o Centro de Estudos e Documentação do MACBA abriu suas portas em dezembro de 2007). Assim, segundo Molins (1996), dessas 
premissas nasceram os princípios que guiariam a atividade do MACBA, de modo que, para o diretor, o Museu se inscrevia em um contexto social e histórico determinado, e em um tecido cultural preexistente, dos quais ele deveria nutrir-se. Ainda, a instituição deveria também ser capaz de atender às necessidades locais e atuar como um lugar de referência na geografia estatal e internacional, ou seja, deveria fornecer um serviço público e uma representação da cultura-mundo (MOLINS, 1996). Também deveria fomentar o pluralismo cultural, refletir em seus discursos e em suas atividades a diversidade cultural e étnica da sociedade contemporânea, a penetração de novos sistemas de valor e estilo de vida, e, portanto, promover a integração cultural e social. Para o ex-diretor, a educação deveria ser tida como uma questão prioritária pelo MACBA, tendo como função fundamental a educação do espectador, o enriquecimento de sua percepção do mundo e de sua existência (MOLINS, 1996). Nesse sentido, o MACBA conceberia a educação como uma dimensão própria da instituição, transversal à toda sua atividade, e capaz de atender públicos diversos, com interesses e níveis de formação artística distintos (MOLINS, 1996).

Molins (1996) elenca os dois eixos ao redor dos quais se configuravam as linhas de trabalho do Museu: as dualidades permanente-atualidade e local-internacional, entendidos não como termos opostos e excludentes, mas sim complementares e interrelacionados. De acordo com o diretor, essas dualidades encontravam sua expressão e seu confronto tanto nos critérios utilizados na construção da coleção do Museu, quanto nas atividades e exposições temporárias realizadas (MOLINS, 1996).

Ao observar as atividades realizadas ao longo da gestão de Miquel Molins, destaca-se sua intenção em aproximar o público das linguagens, teorias e temas da arte. Nesse sentido, foram realizados: seminários, como Art contemporani i espai; La Fotografia. Entre el museu imaginari e les ruines del museu; El llenguatge de les arts e Qué significa conocer una obra de arte, que versaram sobre temas como teoria de arte, arte contemporânea, linguagem, fotografia e arquitetura (MACBA, 1996). Também foram realizadas diversas oficinas voltadas para o público geral, tais como: o programa Lenguaje de las Artes: Taller de Literatura Secreta, que organizou oficinas, dirigidas por membros da Fundação Joan Tabique, em que se buscou trabalhar a linguagem desde o ponto de vista visual, mediante a relação entre o mundo das palavras e o das imagens (Repositório digital MACBA); os Tallers oberts (MACBA,1996), ou oficinas abertas, projeto em que artistas residentes na cidade de Barcelona abriam seus estúdios ao público (MACBA, 1996); oficinas educativas em que se 
buscava explorar os espaços do Museu, bem como abordar as temáticas levantadas pelas exposições, além de empregar técnicas artísticas (MACBA, 1996).

Nota-se também a intenção de aproximar o público do trabalho e dos processos dos artistas, por meio de atividades como: o projeto Vist de prop, em que artistas eram convidados a falar e refletir, junto ao público, sobre seus próprios trabalhos (MACBA, 1996); o projeto Converses a les sales, iniciativa que consistia em uma conversa em que um profissional do mundo da arte falaria sobre o trabalho de determinado artista (MACBA, 1996); o programa $E l$ $M A C B A$ a... realizado junto à Disputació de Barcelona (instituição pública que presta apoio técnico aos ajuntamentos dos municípios da província de Barcelona), que tinha como objetivo aproximar as obras da coleção do Museu de outras populações da Catalunha, com o propósito de levar obras-chave da arte contemporânea a vários pontos da geografia catalã (Repositório digital MACBA).

Também foram realizados seminários, debates e mesas redondas a propósito de exposições em cartaz no Museu, como o Colóquio Cultura y compromiso político en la Barcelona de los Setenta, realizado por ocasião da exposição Pintura dos Setenta em Barcelona. Superficie e Cor (Repositório digital MACBA); a mesa redonda Memoria de una complicidad, a respeito da exposição Pintura de los Setenta en Barcelona. Superficie y Color (Repositório digital MACBA); a palestra Artificialidad y Memoria, ministrada pelo curador e crítico de arte Francesco Bonami, por ocasião da exposição Artificial (Repositório digital MACBA); Palestra do professor Darío Corbeira, que tratou dos conceitos de espaço, tempo e política na obra do artista Gordon Matta-Clark, por ocasião da exposição Gordon Matta Clark 1969-1978 (Repositório digital MACBA). Também a propósito das exposições, eram realizadas visitas guiadas, voltadas para o público geral (MACBA, 1996).

Nota-se, ainda, a realização de oficinas destinadas a jovens artistas, como as referentes ao QUAM (Quinzena d'Art de Montesquiu) e o programa Les Arts: uma forma de coneixement, por meio do qual eles puderam participar de jornadas supervisionadas por artistas mais experientes, que começavam pela exposição De veure la llum, no MACBA, e depois partiam para outros centros culturais da cidade, em uma parceria entre o Museu e as Fundações Miró, Antoni Tapiès e La Caixa, a Filmoteca da Generalidade de Catalunha e o MNAC (Repositório digital MACBA).

Foram realizadas também, no período, programas de vídeo, apresentações de performances e projetos ligados à música. Entre eles, destaca-se Soirées Nomades, que consistiu na realização de concertos realizados em parceria com a Fundação Cartier para Arte 
Contemporânea, além da ativação da obra Espacio Vibrado, uma nova proposta de relação entre música e espaço, composta para e a partir dos espaços do MACBA e executada pelos compositores Alex Arteaga, Carlos Lupprian, Arturo Moya e Doénado el Ur (Repositório digital MACBA).

Entre as exposições realizadas de 1995 a 1998, destacam-se: Apertura de puertas, primeira exposição realizada no prédio projetado por Richard Meier, e que pretendeu apresentar os espaços expositivos do edifício, sendo que havia obras pertencentes à Fundação MACBA, à Prefeitura de Barcelona e à Fundação "la Caixa"; Fondo para uma colección, realizada de novembro de 1995 a junho de 1996, que expôs obras derivadas das vanguardas, em que estavam presentes elementos como a linha e o desenho, a busca por novos materiais, a experimentação, o informalismo, a tendência de raiz construtivista, além de propostas escultóricas e tridimensionais; Fragmentos. Propuesta para una colección de fotografia, realizada entre março e maio de 1996, que pretendeu abordar de questões patrimônio e colecionismo fotográfico, a propósito da exibição de um dos poucos exemplos de coleção privada de fotografia à época, pertencente à Rafael Tous (MACBA, 1996); Miradas (sobre el museo), exposição realizada entre junho e setembro de 1996, para a qual catorze artistas locais e internacionais foram convidados a realizar instalações dentro e fora do edifício do MACBA (MACBA, 1996); Nuevas Abstraciones, exposição que apresentou, entre outubro e novembro de 1996, obras de grande formato, de vinte e nove pintores internacionais que, apesar de manifestarem um interesse comum pela abstração, não se englobavam dentro de nenhum movimento homogêneo, mas sim, por meio de um variado repertório de propostas, questionavam os dogmatismos formais e as visões unívocas da representação (MACBA, s.d); La Revolución del Lenguaje Pictórico, segunda retrospectiva da obra de Vassily Kandinsky na Espanha, realizada entre outubro de 1996 e janeiro de 1997 (MACBA, 1996); Máscara y espejo, exposição que apresentou, entre abril e agosto de 1997, a produção de dez artistas contemporâneas que trabalham fotografando corpos, a fim de tratar de questões de identidades, sejam culturais, sexuais, sociais ou raciais (MACBA,1997); Introversiones: aspectos de la Colección, realizada entre fevereiro e agosto de 1997, foi a primeira ocasião em que o MACBA apresentou parte de sua coleção de forma temática, com o objetivo de mostrar a diversidade de leituras contidas em uma mesma obra e a variedade de aspectos sob os quais elas podem se articular. Foram selecionadas obras que compartilhavam raízes vinculadas ao surrealismo e ao impressionismo, entendidos não tanto como movimentos artísticos, mas como formas de aproximação com a obra de arte (MACBA, 1997); 
Descubierta de la Colección, apresentação da Coleção MACBA realizada entre outubro de 1997 e março de 1998, que pretendeu analisar a história da arte contemporânea a partir do presente, projetando ao mesmo tempo um olhar prospectivo em direção à arte do futuro. A primeira parte da exposição mostrava uma sequência cronológica do período compreendido entre os anos quarenta e a primeira metade dos anos oitenta, sendo que o conceitualismo dos anos setenta era mencionado sobretudo de forma documental, haja vista que ainda não havia, nos Fundos do Museu, obras desse período. Foram exibidas também obras produzidas entre 1987 e 1997, as quais não foram ordenadas de forma cronológica, de modo que se optou por uma apresentação mais aberta, o que permitia o estabelecimento de interrelações em múltiplas direções. A última parte da exposição, de caráter prospectivo, foi protagonizada por uma geração de jovens artistas (MACBA,1997).

De volta aos conflitos entre Molins e a Fundação MACBA, Giralt-Miracle (2007) destaca como, diante dos impasses impostos pela Fundação com relação às propostas de Molins para a coleção, o diretor opta por tornar pública sua discordância e reivindica a independência do diretor, papel que estava condicionado aos estatutos do Consórcio e cerceado pelo intervencionismo da Fundação. O Consórcio não admite as críticas e decisões tomadas por Molins, o que leva a sua saída em fevereiro de 1998. Para Marzo (2014), a tentativa de aliança entre a Fundação MACBA e a Fundação "la Caixa", teria custado a Molins seu cargo de diretor, pois esse teria se negado a abrir terreno à "la Caixa" quanto à autoridade sobre os órgãos do Museu e de sua Coleção, lembrando que a Fundação MACBA é responsável pela aquisição da Coleção que o Museu abriga, da qual é proprietária exclusiva, enquanto a instituição é de titularidade pública (MARZO, 2014). Desse modo, Molins critica a manutenção de uma coleção privada por uma instituição pública (MACBA..., 2013).

Ao analisar tanto o discurso de Miquel Molins quanto os elementos que esse visou priorizar no MACBA durante sua gestão, bem como as atividades realizadas entre 1995 e 1998, pudemos observar que ainda faltava ao Museu a definição de um projeto, de modo que esse não detinha, até então, um programa coeso e integrado. Assim, apesar da realização de algumas propostas interessantes como Converses a les Sales e Vist de Prop, que tinham a intenção de aproximar o público dos processos dos artistas, a realização de oficinas educativas e alguns seminários, tais atividades foram realizadas de maneira solta e desarticulada. Há que se ressaltar, no entanto, que tal falta de definição de um projeto para o Museu não deve ser atribuída a uma falha por parte do diretor, mas sim à ausência de consenso entre as próprias estruturas decisórias no interior da instituição. Quanto ao discurso de Molins, em que o diretor 
assinalou a priorização da educação no que tange às atividades do Museu, incomodou a presença de elementos como a ideia de uma "formação do gosto e da sensibilidade dos visitantes", a ser capitaneada pelo Museu, bem como, ao referir-se a sua função pedagógica, a ideia de "civilizar" e "humanizar", e "dar às pessoas a capacidade de julgar", já que essas pressupõem uma posição hierárquica e vertical do Museu com relação a seu público.

A seguir, adentramos o período conduzido por Manuel Borja-Villel e sua equipe, de modo que procuraremos notar a realização de mudanças quanto à gestão anterior e a consolidação de um programa institucional para o MACBA.

\subsection{A GESTÃO DE MANUEL BORJA-VILLEL (1998-2008)}

Com o término da gestão de Miquel Molins, o historiador da arte Manuel Borja-Villel assume o cargo de diretor do MACBA, em julho de 1998. Advindo da Fundação Antoni Tàpies, também em Barcelona, da qual foi diretor entre 1990 e 1998, Borja-Villel foi responsável, de acordo com Expósito (2015), por modificar a própria natureza do museu, convertendo-o em um protótipo de instituição experimental a partir da qual se poderia refletir sobre a mudança de função que atravessava os museus na era da globalização. De acordo com Borja-Villel (2015), se a Fundação chegara a ser considerada por alguns um "templo da arte moderna situado no Passeio de Gràcia”, ele se esforçou para desmantelar completamente tal visão, concebendo uma relação dinâmica entre a instituição e a cidade, e fazendo com que a experiência no museu permitisse ao público assumir uma consciência crítica quanto à situação da cidade, que passava por um ciclo de remodelação urbana e modernização. O diretor buscou incorporar ao programa da Tàpies atividades que facilitassem o entendimento crítico de como as instituições culturais passavam a desempenhar um papel central na relação com as cidades, ao mesmo tempo que entrava em crise sua função educadora (BORJA-VILLEL, 2015). A gestão bem-sucedida da Fundação Tàpies faz com que Borja-Villel seja então convidado a assumir uma instituição de maior porte como o MACBA. Vale lembrarmos, aqui, como Charles Esche destacou a respeito da possibilidade que experimentações em instituições de menor parte teriam de inspirar mudanças também em outras maiores e, por isso, capazes de alcançar um maior público.

É importante destacar que Borja-Villel assume o cargo no MACBA em meio a uma crise, conforme explica Expósito (2015), resultante tanto da persistente indefinição de um projeto para o Museu, como das próprias tensões do ciclo político local das décadas de oitenta e noventa. A começar, verifica-se que os dirigentes dos distintos órgãos envolvidos no 
Consórcio tinham projetos de construção nacional e metropolitana conflitantes, de modo que o de Jordi Pujol, que assumiu a presidência da Generalidade da Catalunha em 1980, detinha caráter conservador, enquanto o de Pasqual Margall, eleito prefeito de Barcelona em 1982, era progressista (EXPOSITO, 2015). Assim, de acordo com Expósito (2015), o MACBA resultou de pactos nem sempre harmoniosos entre setores das elites políticas, econômicas e intelectuais locais, que não eram concordantes entre si. Desse modo, no que tange às divergências quanto ao projeto para o Museu, alguns almejavam que a instituição adotasse a função clássica de um museu orientado a construir uma identidade nacional baseada na cultura, enquanto outros desejavam que esse representasse o cosmopolitismo da Barcelona moderna, projetada nos mercados globais (EXPÓSITO, 2015). É nesse contexto que se dá a entrada de Borja-Villel na instituição, e cujo projeto, de acordo com Expósito (2015), evidencia o esgotamento desses dois modelos anteriores.

Segundo Giralt-Miracle (2007), com a nomeação de Borja-Villel para o cargo de diretor, o Consórcio chega finalmente a um acordo, aceitando o MACBA como um museu nacional e internacional. Para Giralt-Miracle, Borja-Villel será capaz de realizar uma mudança radical de perspectiva com relação à definição do Museu e de suas coleções, o que irá por propiciar, a seu ver, uma "refundação" da instituição.

Borja-Villel (2002), explica como a inauguração do MACBA se inscreve em uma série de ações levadas a cabo em Barcelona durante os anos oitenta e a primeira metade dos noventa que tiveram como objetivos a reordenação urbana da cidade, assim como sua orientação em direção a um tipo de economia expansiva, sustentada essencialmente pelo setor terciário e de turismo. Tais mudanças ocorridas em Barcelona acompanham as de outras cidades, num contexto de transformação dos modos de produção a partir da mundialização do capital e da globalização (BORJA-VILLEL, 2002). Ele destaca a transformação, à época, por parte do capital, do espaço da vida diária em espaço gerador de riquezas, bem como evidencia o debate acerca da alteração profunda da cultura em uma época em que as grandes empresas de entretenimento haviam descoberto o valor da cidade e de seus turistas como parte de estratégias de marketing, tendo o museu também se transformado em espaço de disputa (BORJA-VILLEL, 2002). O diretor assinala, à época, o que chamou de "hiperatividade cultural atual", representada pela proliferação de museus como parte de uma nova fase na sociedade de consumo ocidental. Desse modo, Borja-Villel (2002) acaba por alertar para a crescente museificação da sociedade em geral, contexto em que artistas e obras seriam apenas pretextos para que o mundo da arte não deixasse de girar, um mundo que parecia necessitar 
continuamente do espetáculo artístico, de novos objetos e formas com as quais satisfazer uma curiosidade que devora todo modo de expressão novo, e que, frequentemente, acabava por ser esvaziado de conteúdo crítico no processo (BORJA-VILLEL, 2002). O diretor critica então a demanda de que os museus configurassem um programa artístico idealizado em função de uma concepção utilitária de arte como uma forma de atrair turistas, e que primava pelo espetáculo, em detrimento da cultura como como lugar capaz de recriar a esfera pública e questionar nossa posição no mundo (BORJA-VILLEL, 2002). Assim, para o diretor, o museu e a cidade haviam se tornado uma espécie de parque temático, situado em um presente contínuo, disfarçado de falsa memória e no qual as relações entre os indivíduos baseavam-se no consumo, e o sujeito político era substituído pelo consumidor (BORJA-VILLEL, 2002). Desse modo, o programa de gestão proposto por Borja-Villel emerge justamente para fazer frente a esse modelo instrumentalizado de museu, sendo que não é nenhuma coincidência que o discurso do diretor coexista com a inauguração da monumental franquia da Fundação Guggenheim na cidade basca de Bilbao.

Tendo em vista tal contexto, o artista e curador independente Jorge Ribalta (2009), que atuou como diretor de Programas Públicos no Museu de 1999 a 2009, explica que os trabalhos realizados no MACBA a partir da gestão de Borja-Villel consistiram em um projeto de regeneração institucional, com o objetivo de oferecer um modelo satisfatório de museu. Nesse sentido, Ribalta (2009) assinala como, sob a ditadura de Franco, que dominou o período central do século XX, a Espanha ficou às margens do desenvolvimento de instituições de arte moderna, internacionalmente em ascensão a partir do modelo implantado pelo Museu de Arte Moderna de Nova Iorque nos anos trinta, e que se generalizou pela Europa após a Segunda Guerra Mundial (RIBALTA, 2009). Sendo assim, de acordo com Ribalta (2009), apenas ao final dos anos oitenta a Espanha aderiu ao processo de modernização das instituições de arte, uma vez que a democracia fora restaurada. Porém, tal modernização viera acompanhada de imperativos econômicos e relacionados ao turismo e ao modelo de crescimento do capitalismo pós-industrial e neoliberal. Desse modo, ainda de acordo com Ribalta (2009), o desenvolvimento das instituições de arte no país foi determinado pelo paradigma da indústria cultural, que negligenciava o papel educacional do museu como parte constituinte da esfera pública (RIBALTA, 2009). Diante disso, de acordo com o autor, os anos que abarcaram esse processo de regeneração institucional no MACBA representaram um contra modelo à concepção instrumentalizada que dominou a emergência dos museus na Espanha nos anos oitenta e noventa (RIBALTA, 2009). Ainda a respeito desse contra modelo, 
Ribalta (2009) enfatiza que a significância dessa experiência do MACBA não estaria limitada à escala nacional, de modo que deveria ser percebida no contexto internacional do debate sobre arte e o museu. Ele ainda se refere a um modelo MACBA, que constituiria um entendimento singular do museu como espaço para debate e conflito, bem como uma releitura crítica da tradição moderna, que reúne métodos artísticos, conhecimento social e ação na esfera pública como uma maneira de reinventar o campo da arte e atribuir-lhe um novo significado e legitimidade social (RIBALTA, 2009). O diretor de Programas Públicos destaca um aspecto fundamental adquirido pelo MACBA no período em questão: sua capacidade para experimentação institucional, que se fez possível a partir de uma leitura singular dos debates e experiências do movimento de crítica institucional desde os anos sessenta, e que levou a propostas de reinvenção do Museu e sugestão de hipóteses para um novo tipo de instituição (RIBALTA, 2009).

\subsubsection{Mudanças de Borja-Villel com relação à gestão anterior}

Aqui observaremos importantes mudanças adotadas pelo MACBA a partir da gestão de Manuel Borja-Villel, que passam pelo desenvolvimento de um programa integrado e coeso, pautado em um sólido discurso e posicionamento político por parte do diretor e sua equipe, a ampliação arquitetônica da estrutura do Museu e sua própria reconfiguração institucional.

\section{O Departamento de Programas Públicos}

Borja-Villel (2015) explica como, até 1998, o MACBA possuía um Departamento Educativo, o que é muito comum em centros de arte de diversas cidades do mundo, e cujo objetivo era, supostamente, tornar a arte mais acessível a um público geral. O problema, no entanto, argumenta o diretor, é que muitos dos programas educativos dos museus baseiam-se em uma relação hierárquica entre a instituição, que supostamente detém o conhecimento, e o público sem formação artística, que, supostamente, não o detém (BORJA-VILLEL, 2015). Nesse contexto, de acordo com Borja-Villel (2015), a transmissão de conhecimento produz-se de forma conservadora, assimilando as obras de arte a um sistema de princípios normativos, que têm que ser ensinados e aprendidos de tal maneira que não se questione a percepção estabelecida do mundo. Outro elemento que passou a influir na forma como eram manejados os departamentos educativos de museus e centros de arte, de acordo com o diretor, foi o 
retrocesso do financiamento público da arte e da cultura, de modo que as instituições passaram a se preocupar em facilitar a compreensão da arte, devido à influência que passava a ter sobre elas o investimento privado. Nesse sentido, Borja-Villel (2015) se utiliza do termo giro educativo, que indica a intenção, por parte das instituições de arte, de incorporar o maior número de público possível, a fim de conseguir adesões, patrocínios e subvenções.

Em contraposição a essa visão, a medida proposta pelo diretor foi a de substituir o Departamento de Educação do MACBA por um de Programas Públicos. Tal medida teve como objetivos ajudar a fazer do MACBA um verdadeiro espaço público, bem como reformular a noção moderna de educação, a partir do ponto de vista da pedagogia radical (BORJA-VILLEL, 2015). Isso significava pensar a instituição não apenas como um lugar no qual se realiza a transferência de conhecimento, mas sobretudo um local que abrigue o dissenso e a crítica (BORJA-VILLEL, 2015). O Museu deveria também proporcionar maneiras de dotar os cidadãos de "instrumentos de agência", oferecendo-lhes mais ferramentas para que pudessem pôr em prática sua capacidade política através da instituição, em um processo interativo (BORJA-VILLEL, 2015).

\section{A Introdução do Político no Museu}

A segunda mudança adotada por Borja-Villel e sua equipe consistiu na introdução de debates e reflexões prementes, tanto em âmbito local como global, dentro do MACBA, de modo a flexibilizar a ênfase sobre a criação artística que marcara as atividades da gestão anterior. A esse respeito, o diretor menciona alguns eventos cruciais na introdução "do político" no Museu, como a realização do seminário Globalización y diferenciación cultural, em 1999, em que participaram pensadores de diversos países, como a historiadora e crítica de arte Geeta Kapur, de Nova Délhi, o jornalista espanhol baseado na França Ignacio Ramonet, o escritor sul-africano J. M. Coetzee, e no qual foram discutidos temas como historiografia colonial, reconsideração do imaginário racista do apartheid por meio da literatura e jornalismo comprometido com a crítica da globalização. Ele também enfatiza a participação da cientista política belga Chantal Mouffe, que expôs suas ideias acerca de como o antagonismo e o dissenso são consubstanciais a toda sociedade democrática, tendo se tornado uma grande referência para a equipe do Museu, de modo que suas análises políticas serviram à equipe para reformular, de maneira conflitiva, o modo como se havia construído a história da arte, sobretudo na Espanha (BORJA-VILLEL, 2015). Borja-Villel (2015) destaca as 
participações, em outros eventos e seminários, de Angela Davis, histórica militante do grupo Black Panthers e atual ativista contra prisões; Toni Negri, filósofo e militante italiano, que propôs a reflexão acerca das mudanças no modelo produtivo capitalista e o surgimento de novas resistências globais; Precarias a la Deriva, coletivo feminista de pesquisa sobre a precariedade; Gayatri Spivak, filósofa feminista indiana propulsora dos estudos coloniais; a teórica queer Judith Butler; a ativista pós-pornô Annie Sprinkle; Naomi Klein, jornalista e ativista contra o neoliberalismo, entre outros (BORJA-VILLEL, 2015).

\section{Modificar a narrativa sobre a História da Arte por meio de uma nova política de coleção e mediante um novo programa de exposições}

Ao assumir o cargo de diretor no MACBA, Borja-Villel (2015) conta como a coleção do Museu estava orientada pelo modelo tradicional, baseado no monumentalismo das grandes obras e dos grandes nomes-marca, habitualmente sobrevalorizados pelo mercado. Diante disso, foi proposta, em primeiro lugar, uma reorientação da coleção em direção a um tipo de obra frágil, em menores formatos, sobre papel ou materiais perecíveis. Assim, explica o diretor, materiais como livros e maquetes passaram a ter a mesma importância de obras consideradas tradicionalmente "superiores", de modo que se tratava de construir uma coleção que não fosse autoritária, mas que permitisse algum tipo de relacionalidade com o espectador (BORJA-VILLEL, 2015).

No que tange à proposta de reorganizar a coleção, seu epicentro foi direcionado aos conflitos não resolvidos das décadas de sessenta e setenta. Borja-Villel (2015) explica que decidiu voltar a esse período pois trata-se do grande ponto de inflexão do século passado, em que uma série de rupturas de ordem institucional, política e social provocaram uma crise das instituições e da política modernas, fazendo emergir dela processos sociais, princípios políticos e ideias novas, de modo que, de alguma forma, nossa era contemporânea começava nesse ponto (BORJA-VILLEL, 2015). Desse modo, verifica-se a realização de mostras da Coleção MACBA com o objetivo de configurar uma memória crítica da arte da segunda metade do século XX, levando em consideração a realidade cultural e política do entorno e considerando a História da Arte como uma construção, e não uma narrativa acabada e única, estando, portanto, sujeita a mudanças (MACBA, 2000). Como exemplos, temos a mostra de novas incorporações (2000), que, junto a obras exibidas anteriormente, refletiam as orientações e as linhas de trabalho do MACBA no momento. A exposição se articulou em 
torno de quatro períodos que correspondiam a quatro momentos históricos precisos. $\mathrm{O}$ primeiro tinha como ponto de partida simbólico a criação da revista Dau al Set, em 1948, por Antoni Tàpies, Joan Brossa, Modest Cuixart e Joan Ponç, que supunha uma tentativa de se conectar com as vanguardas do pré-guerra, especialmente aquelas vinculadas ao surrealismo (MACBA, 2000). Trata-se do momento da consolidação progressiva do estado de Bem-Estar Social e a primeira aparição massiva de publicidade e meios impressos no entorno urbano. A arte dessa segunda modernidade adotou duas tendências vinculadas à abstração: por um lado, o informalismo, no qual o espaço pictórico se converte no suporte da ação mais ou menos espontânea da consciência do artista, que se cristaliza em uma matéria pictórica informe. Como exemplos, destacam-se Antoni Tàpies, Antonio Saura e Jean Dubuffet. Por otro lado, existe uma tendência fundamentada no funcionalismo e no constructivismo das vanguardas europeias, em que a abstração é o resultado de uma buca por ordem, claridade, equilíbrio e objetividade, que dará lugar à arte concreta, e exemplifica em Jorge Oteiza e Pablo Palazuelo (MACBA, 2000).

O segundo período da Coleção, que compreende as décadas dos sessenta e setenta, correponde à aparição de novos discursos críticos, cujo emblema é maio de 1968. Questionase a atividade artística orientada para a produção de objetos, em favor dos processos e as condições da obra. Um dos artistas fundamentais desse período é Marcel Broodthaers, cujo trabalho adota meios como escritura, grafismo, instalação, cinema, etc., e aborda as consequências da transformação da produção artística sob a expansão da cultura do consumo, iniciada a partir dos anos sessenta, assim como a transformação do museu pelo impacto das novas práticas e do pensamento crítico dos novos movimentos sociais. A atividade, a informação e o debate são os eixos que articulam a criação artística desse momento, que se exemplifica no trabalho de artistas conceituais catalães, como Antoni Muntadas, Francesc Abad, Fina Miralles o Francesc Torres (MACBA, 2000). Outra figura chave é Dan Graham, em cujo trabalho se combinam os fundamentos conceituais dos sessenta com elementos pósfuncionais $\quad$ tardomodernistas 2000). Pioneiro no uso artístico do vídeo e de grande influência como ensaísta, seu trabalho avança inquietudes que, a serão dominantes na esfera artística, como a concepção híbrida entre trabalho artístico e arquitetônico, o valor de uso e a noção de serviço. Este segundo período termina ao final dos anos setenta, quando o impacto internacional da crise do petróleo de 1973-1974 rompe as bases do Estado de Bem-Estar (MACBA, 2000). 
Durante o terceiro período, começa a consolidação da globalização econômica, e se inicia uma hegemonia que se irá consolidar durante os anos oitenta e noventa. O efeito desse processo no âmbito artístico se manifestou sobretudo em duas direções: por um lado, produziu-se um movimento que restaurou formas artísticas tradicionais, tanto modernas como pré-modernas (MACBA, 2000). O retorno à pintura caracterizou os principios dos oitenta, com os movimentos neoexpresionistas ou neoselvagens, e a busca por uma reinscrição dos grandes formatos e os gestos da pintura tradicional no âmbito de um mercado artístico revitalizado, assim como uma expansão dos museus de arte contemporânea em escala mundial. Como exemplos deste retorno à pintura encontram-se Miquel Barceló, Ferran Garcia Sevilla, Anselm Kiefer, Keith Haring, Jean-Michel Basquiat e A. R. Penck (MACBA, 2000). Por outro lado, essa recuperação da pintura também teve consequências na fotografia: na década de 1980, a fotografia adentrou com força a cena artística e se converteu no meio mais significativo para as teorias da la crítica da representação, vinculadas a certos postulados pósmodernos. Nesse momento, apareceu a noção de quadro fotográfico como estratégia por meio da qua a fotografía podia ocupar os espacios arquitetônicos e culturais da pintura. Nesse âmbito se destacam os trabalhos de Jeff Wall, Craigie Horsfield, Suzanne Lafont e Jean-Marc Bustamante (MACBA, 2000).

O quarto período se inicia simbolicamente em 1989, com a queda do muro de Berlim. Nessa nova fase histórica culmina o processo de globalização, favorecido pela expansão das novas tecnologias. Um fenômeno determinante nesses anos é a imersão da cultura nos processos de consumo e entretenimento de massas. Por un lado, temos em artistas como Mike Kelley ou Tony Oursler uma complacência nos fenômenos de cultura popular e do kitsch, assim como uma celebração do universo da mercadoria, que preludiam artistas como Carlos Pazos e Zush. Por oturo lado, critica-se a aparente banalização do popular e se conservam posições legitimadas na grande tradição moderna, que conduzen em direção a formas artísticas de certo hermetismo, em que se busca a complicidade do espectador. Assim, encontramos obras de artistas como Pep Agut, Jordi Colomer e Ignasi Aballí (MACBA, 2000).

Ademais, o vídeo, a videoinstalação e as tecnologias informáticas substituem a anterior hegemonia da fotografia. O novo potencial do imaginário digital transforma a noção de representación, fazendo com que aparentemente não se distinga entre o real e o virtual. A reformulação da relação entre o corpo e o espaço é uma das manifestações desse novo paradigma artístico (MACBA, 2000). 
A mostra de obras da Coleção realizada entre julho e outubro de 2003 propôs uma articulação histórica da arte dos últimos cinquenta anos, por meio da exposição de mais de 160 obras. O primeiro núcleo da exposição partiu da confrontação dos discursos que dominaram o debate artístico a partir dos anos cinquenta, no contexto da crise de valores ligados ao pós-guerra europeu. A Coleção reuniu múltiplas respostas à época e seus conflitos, da eclosão do informalismo pictórico europeu aos novos realistas e o cinema neorrealista. Verifica-se que a imagem cinematográfica desempenha papel relevante na Coleção, à medida que se materializa a vontade de superar a fronteira entre testemunho e ficção narrativa, e entre poética e política. Ainda, dentro do discurso dos novos cinemas dos anos sessenta, cabia distinguir a tendência documental, que reflete uma nova experiência da cidade, determinada pela profunda transformação do espaço público que comporta a presença da arquitetura moderna, a transformação dos centros históricos e a aparição massiva da publicidade, o que se reflete no trabalho de Joan Colom, com filme realizado em 1960 no Bairro Chinês de Barcelona (atual Raval). Também é abordado o cinema como um território de experimentação vanguardista, como mostra Film (1965), de Samuel Beckett. O primeiro núcleo da exposição ainda abarcava duas tendências aparentemente contraditórias, vinculadas à abstração: por um lado o informalismo, com artistas como Antoni Tàpies e Lucio Fontana, além de outros que refletem subjetivamente a situação política espanhola, como Antoni Saura e Manuel Millares, do grupo El Paso. Por outro lado, a abstração, como resultado da busca pelo equilibrio, a ordem e a objetividade, dá lugar à arte concreta, cujas duas figuras principais em Espanha são Pablo Palazuelo e Jorge Oteiza. No segundo núcleo da exposição, estavam trabalhos que interrompem a homogeneidade abstrata do espaço pictórico, ao incorporarem a ele objetos reais que enfatizam as condições materiais da obra, em detrimento do ilusório e representativo, como mostram obras de artistas como Robert Rauschenberg e os novos realistas franceses, em Raymond Hains. Este gesto constitui um prelúdio do novo materialismo que caracterizará a arte na década de sessenta, a partir do minimalismo e da arte pop. Por fim, o terceiro núcleo teve como precedentes os filmes de Jack Goldstein e as obras fotográficas de Hans-Peter Feldmann, que vinculam os postulados pós-conceptuais com uma nova geração de artistas de Los Angeles como Mike Kelley, Tony Oursler e Raymond Pettibon, que têm em comum seu interesse pela cultura popular e sua preocupação pelos estereotipos midiáticos e o carácter fictício da representação fotográfica. A obra dos suíços Fischli e Weiss enlaça o interesse pela cultura popular com a revisão da percepção do cotidiano, como mostra o vídeo Büsy (Kitty) de 2001 (MACBA, 2003). 
Em 2009, é realizada uma seleção das aquisições realizadas entre 2002 e 2007, publicada no catálogo Objetos Relacionales. As obras são nele divididas em quatro eixos. O primeiro é: Outros modernismos: Informal e Concreto, Documentário e Experimental. Os Quarenta e os Cinquenta, que propôs mostrar a predominânciana Europa do pós-guerra, não do Expressionismo Abstrato, como promovera o MoMA, mas da Abstração Informal, termo cunhado por Michel Tapié, usado para tratar de pinturas que enfatizavam a materialidade física e opaca do meio, ou a expressão espontânea. Na Coleção MACBA, o termo está representado por artistas como Jean Dubuffet, com a obra Le chien jappeur (1953), Antoni Tapiès, com Pintura ocre (1959) e Forma blanca (1959), Henri Michaux, com sua série de desenhos e pinturas de caráter caligráfico, realizados a partir de 1950, parte dos quais está presente na Coleção MACBA. Também são apresentados trabalhos de estética construtivista, como a escultura Conjunción dinámica de dos pares de elementos curvos o livianos (1957), de Jorge Oteiza, e as obras Estudio para 'Alborada' (1950) e Cosas olvidadas IV (1952), de Pablo Palazuelo, os quais compartilham de uma rejeição à abstração racionalista que presume uma correspondência entre o que se pensa e o que se vê. Destaca-se, ainda, como tais artistas possuem histórias singulares que não podem ser facilmente acomodadas dentro de uma história da arte ocidental dominante (BORJA-VILLEL; CABAÑAS; RIBALTA, 2009). Com trabalhos como esses, o MACBA busca oferecer entendimentos alternativos do modernismo, contrapondo narrativas dominantes na história da arte, como é o caso do Expressionismo Abstrato Americano (BORJA-VILLEL; CABAÑAS; RIBALTA, 2009). Quanto à fotografia e vídeo, fazem parte da Coleção obras comprometidas com a representação sócio-histórica e de caráter documental, como In the Street (1945-46 [1952]), de Helen Levitt, filme que exibe a realidade do Harlem por meio de cenas de crianças e seus parentes, bem como NYC Sagamore Cafeteria (1948) e 14th of July 1948. Day becomes night... (1948), de Robert Frank, também voltadas para a representação de grupos minoritários. Já em Hurlements em faveurs de Sade (1952), de Guy Debord e Film (1965), de Samuel Beckett, verifica-se o uso do vídeo e da fotografia como ferramenta de experimentação (BORJA-VILLEL; CABAÑAS; RIBALTA, 2009). O segundo eixo, Viradas Discursivas: Linguagem, Instituição, Cinema. Do final dos anos cinquenta aos setenta, parte da exploração, por parte de artistas, entre o final dos anos cinquenta e os setenta, de várias modalidades da linguagem escrita e falada, seja por meio dos scripts do Fluxus, que descreviam ações a serem performadas, ou através do engajamento com práticas discursivas social, institucional e historicamente pertinentes. As obras presentes na Coleção MACBA apresentam alternativas ao entendimento dominante da 
linguagem como um sistema, bem como ao pressuposto, em teorias da comunicação, de que as mídias de massa serviram como transmissores neutros de informação (BORJA-VILLEL; CABAÑAS; RIBALTA, 2009). Destaca-se também como, ao final dos anos cinquenta, artistas buscaram dissolver os limites entre arte e vida, participando de grupos internacionais como o Fluxus. Nesse contexto, os livros de Dieter Roth usaram a linguagem e as páginas como locais para a produção de arte, ao passo que, ao utilizar comida como material escultórico, o artista desenvolveu uma estratégia consistente de subversão dos mecanismos de comercialização da arte, visível em obras como Untitled (Kleiner Schimmelhaufen) (1968), presente na Coleção, atitude que também se verifica no trabalho de George Brecht, contemporâneo de Roth, cuja obra Water Yam, originalmente publicada em 1963, integra a Coleção (BORJA-VILLEL; CABAÑAS; RIBALTA, 2009). Destaca-se também a presença, na Coleção, obras de artistas que buscaram a experimentação entre cinema e artes visuais, tais como Line describing a cone (1973), de Anthony McCall, Film Script (La manipulación del mensaje) (1972), de David Lamelas, Cutting (1967), de VALIE EXPORT e Attack Piece (1975), de Dara Birnbaum. Alguns dos trabalhos referentes a esse eixo também questionam o entendimento dominante da arte Conceitual, a fim de ressituar suas variadas práticas dentro de um campo mais amplo de negociação na produção de significados artísticos e sociais. Nesse sentido, verifica-se o projeto coletivo Tucumán Arde, bem como o coletivo catalão Grup de Treball, cujos trabalhos estão documentados na Coleção. Os trabalhos coletivos de ambos os grupos se distanciavam das práticas artísticas convencionais, a fim de engajar-se com a função social da arte (BORJA-VILLEL; CABAÑAS; RIBALTA, 2009). O terceiro eixo, Ordem e Desordem Espacial: Arquitetura, Fotografia, Cultura Popular. Final dos Anos Setenta e Anos Oitenta é composto por obras de artistas que representam um retorno à figuração e a pintura neo-expressionista caraceterísticos dos anos oitenta. Entre os artistas presentes na Coleção MACBA, Manolo Laguillo, que apresenta fotografias como Diagonal/Aragó (1978) e Frente a la Sagrada Familia (1981), que conflituam com as imagens publicitárias referentes ao novo planejamento urbano de Barcelona; Jeff Wall, que se utilizou da pintura não para reviver a expressão, mas para desafiar noções tradicionais do gênero; Juan Muñoz, que se engajou em trabalhos escultóricos que buscavam "expressar sem ser expressionistas", como The Nature of Visual Illusion (1994); Dan Graham e James Coleman, que exploraram os processos de percepção e como esses informam os espaços da arquitetura e o significado das imagens, respectivamente, com obras como Alteration of a Suburban House (1978-87), de Graham e Slide Piece (1972-73), de Coleman (BORJA- 
VILLEL; CABAÑAS; RIBALTA, 2009). O quarto eixo é Participação: Arquivos, Documentários, Relações. Os Anos Noventa e Dois Mil. Com relação a esse período, a Coleção do MACBA isola modalidades particulares de prática artística contemporânea que dialogam com as condições da globalização, a produção de conhecimento, e como engendrar novas relações com os públicos da arte. Nesse contexto, muitos artistas exibem o que Hal Foster denomina "impulso arquivista", enquanto outros se voltam para modos documentais de produção tanto em vídeo como na fotografia, a fim de abordar questões sociais contemporâneas e a tarefa da representação histórica. Destaca-se também como, por meio de conceitos como "estética relacional", "comunidade", "sensorium", e o chamado à "participação", artistas contemporâneos têm tomado o legado artístico dos anos sessenta e desenvolvendo novas relações com os públicos. Verifica-se, nesse eixo, a presença de trabalhos como o Archivo $F X$, de Pedro G. Romero, uma coleção que documenta casos de iconoclastia anticlerical na Espanha durante o período entre as revoluções do século XIX e a Guerra Civil; as práticas documentais de Ursula Bienmann, como o filme Performing the Border (1999), de Chantal Akerman, com Une voix dans le desert (2002), e Alexander Sokurov, com Spiritual voices: From the Diaries of War (1995). A Coleção também abarca obras que buscam experimentação quanto às possibilidades de reinvenção do documentário, como em La tierra de la madre (1994), de Marcelo Expósito, e que se estende também para a fotografia, com a projeção Waiting for Tear Gas (1999-2000), de Allan Sekula. A Coleção também buscou adquirir obras que tratam de novas formas de relação, como Alien Staff (1992-93), de Krzysztof Wodiczo, um equipamento portátil que dava aos imigrantes a oportunidade de contar suas histórias (BORJA-VILLEL; CABAÑAS; RIBALTA, 2009).

Em 2007, foram incorporadas mais de 200 obras à Coleção do MACBA, fruto de aquisições, doações e depósitos. Entre essas novas incorporações destaca-se a obra Shapolsky et al. Manhattan Real State Holdings, a Real-Time Social System, as of May 1, 1971, de Hans Haacke, adquirida pela Fundação MACBA junto com o Whitney Museum of American Art de Nova York; a compra de cinco filmes de Dan Graham: Roll; Binocular Zoom; Helix/Spiral; Helix/Spiral (Simone Forti) e Sunrise to Sunset, que datam do período entre 1969-1973; o depósito de 35 desenhos de Pablo Palazuelo, realizados entre 1956 e 1993, pela Fundação Pablo Palazuelo, após a realização de grande exposição do artista no MACBA. Também foi realizado um depósito de obras de Roy Arden, Jean-Louis Garnell, Matt Mullican, Gabriel Orozco, Cindy Sherman e Stephen Shore procedentes da Colección Ordóñez Falcón. A Fundação MACBA adquiriu também para a Coleção do Museu obras de Deimantas 
Narkevicius e Rosalind Nashashibi, de Ibon Aranberri, Craigie Horsfield e Manolo Laguillo. Ademais, somaram-se ao acervo do MACBA três obras de Frederic Amat e vídeos de artistas como Vito Acconci, Joseph Beuys, Jef Cornelis, Robert Filliou, Donald Goodes/Anne Marie Léger, Dan Graham, Joan Jonas, Gordon Matta-Clark, Rafael Montáñez Ortiz, Bruce Nauman, Tony Oursler e Martha Rosler. Entre as doações, destaca-se a de Allan Sekula, que doou sua obra 'Shipwreck and Workers' (2005-2007), uma instalação fotográfica formada por 26 paineis de grande formato e concebida para ser mostrada em espaços exteriores, apresentada na Documenta 12, em Kassel (EL CULTURAL, 2007).

Ainda a respeito da intenção de modificar a narrativa sobre a História da Arte, Marcelo Expósito (2015) nota, no projeto de Borja-Villel, como esse buscou recuperar nomes subestimados ou marginalizados pelos relatos canônicos, ou seja, não se tratava de incluir novos nomes nas narrativas já existentes, mas sim, ao contrário, de reconsiderar o cânone historiográfico desde o ponto de vista daqueles por ele excluídos. Assim, de acordo com Expósito (2015), aquilo que havia sido invisibilizado emergiria para colocar o relato oficial em crise. Para o autor, trata-se, pois, de uma maneira como o trabalho museográfico pode ajudar a transformar o sentido comum sobre a História (EXPÓSITO, 2015). Como exemplos, Borja-Villel (2015) cita a realização de exposições como a retrospectiva do coletivo de arte conceitual catalão Grup de Treball (1999), que atuou em Barcelona principalmente entre 1973 e 1975. A exposição mostrava a totalidade da atividade do grupo, que operou durante o clima de radicalização política dos últimos anos do franquismo, e intencionou mostrar uma cara oculta da história canônica da arte catalã (BORJA-VILLEL, 2015). O diretor cita também a exposição sobre o cineasta Pere Portabella (2001), que fora integrante do Grup de Treball e, que, apesar de ser um personagem público muito conhecido por sua trajetória política, tivera seu trabalho descuidado pela historiografia e pela crítica (BORJA-VILLEL, 2015).

Além disso, o diretor assinala a vontade de apresentar um tipo de arte ligada mais às formas de ativismo que à tradição das belas artes. Como exemplo, o diretor refere-se à retrospectiva Posiciones en el mundo real [1999-2000] acerca da obra da artista estadunidense Martha Roesler, um dos nomes mais importantes no que diz respeito às rupturas produzidas na arte dos anos sessenta e setenta, e cujos trabalhos não se enquadram em um estilo no sentido tradicional, mas transitam por uma multiplicidade de suportes (BORJA-VILLEL, 2015). No mesmo contexto, vale destacar também Arte y Acción (19981999), exposição de caráter histórico que pretendeu analisar a relação que se estabelece entre ação, performance e processo criativo, tendo em vista como a característica comum da arte de 
ação foi a desconstrução radical do conceito moderno de criação artística, de modo que, ao rechaçar toda a atitude formalista e incorporar, em seu lugar, atividades performativas, os artistas alcançaram a desmaterialização de seus trabalhos (MACBA, 1998). Podemos citar, também, a exposição Edición Agotada (2002), que mostrou uma seleção de setecentas obras e documentos pertencentes ao Archive for Small Press \& Communication (ASPC) do Neues Museum Weserburg de Bremen, e cujos fundos estão compostos por trinta e cinco mil peças, como obras gráficas e sonoras, múltiplos, periódicos, revistas, cartazes, vídeos e livros, de modo que os fundos do ASPC refletem um período em que os artistas utilizavam meios alternativos para publicar e comunicar suas ideiais a um público que já não se conformava com os circuitos artísticos tradicionais (MACBA, 2002).

É importante destacar também, ainda de acordo com Borja-Villel (2015), que, no sentido de modificar a narrativa da História da Arte, houve também a organização de exposições cujas obras não estivessem necessariamente vinculadas ao ativismo social, ou fossem dotadas de conteúdo político, mas que, mesmo assim, rechaçavam que a experiência estética devesse ser reduzida a um mero ato de consumo, como foi o caso da exposição Arte y utopía, ou que provocavam no espectador mudanças de percepção sobre a obra e sua realidade circundante, caso da exposição Campos de fuerzas (2000). Curada pelo britânico Guy Brett, essa pretendeu mostrar uma parte da história de como a arte havia deixado de representar a realidade, passando a nela intervir materialmente, brindando ao espectador modelos ou ferramentas para modificá-la e rompendo com a divisão por meio da qual a arte do século XX é habitualmente ensinada, classificada por suportes, estilos e escolas (BORJAVILLEL, 2015).

Outras importantes ferramentas adotadas durante o programa de Borja-Villel, e que contribuiu para o objetivo de propiciar novas narrativas de modo a romper com o cânone da História da Arte, foram as exposições temáticas ou de tese, de modo que se partia de teses políticas para dar forma às exposições (EXPÓSITO, 2015). A primeira desse tipo foi Antagonismos. Casos de estudio, realizada em 2001, e que, de acordo com Borja-Villel (2015), propôs um relato historiográfico sob a forma de um ensaio, composto por estudos de caso dispostos como áreas independentes, e distribuídos horizontalmente. Entre os casos, estavam temas como a crítica artística das instituições, as formas de enfrentar a mercantilização da obra desde o interior do próprio sistema artístico, as práticas artísticas baseadas nas políticas de identidade em torno de questões de gênero e raça, a arte conceitual que se utilizava da informação como matéria-prima, a arte política realizada sobre bases 
documentais, a pedagogia radical na Kunstacademie de Düsseldorf, além de projetos como Tucumán Arde e a atividade de coletivos como o chileno Colectivo Acciones de Arte (CADA). A exposição pretendeu contrapor a historiografia eurocêntrica e neocolonial, a fim de relatar uma história mais plural da modernidade, incorporando uma visão externa à Europa (BORJA-VILLEL, 2015). Outra exposição temática realizada foi Casas im-propias (2001), que pretendeu analisar a evolução do conceito de privacidade nas habitações contemporâneas, sob a perspectiva das vertentes arquitetônica-formal e ético-social. Os mais de trinta projetos arquitetônicos apresentados interpretaram os novos modos de habitar, os conceitos mutáveis de ócio e trabalho e as novas condições de mídia e tecnologia. Foi também proposta uma reflexão mais radical sobre situações de emergência e falta de habitação, algo comum entre a população menos privilegiada das grandes cidades e na maioria dos países em desenvolvimento (MACBA, 2001)

\section{A articulação entre as exposições, a coleção e as atividades de Programas Públicos}

Trata-se de um dos aspectos que torna distintivas as instituições experimentais em questão neste trabalho, organizadas de modo a primar por um programa integrado que não privilegie a visualidade da exposição sobre as outras atividades, mas sim consigam trabalhar temas relevantes sob diferentes formas. Assim, ao ser questionado por Expósito (2015) sobre algum projeto em particular realizado no MACBA durante a sua gestão que detenha tal característica, Borja-Villel (2015) destaca aquele realizado junto a Jean-François Chevrier em torno da obra do artista Öyvind Fahlström, em 1999. Nesse projeto, interessava especialmente ao diretor o deslocamento experimental da geopolítica global presente em algumas obras do artista, especialmente seus mapas, realizados por meio de procedimentos lúdicos e de representações imaginativas da realidade (BORJA-VILLEL, 2015). Como parte do projeto, foi instalado um arquivo do artista em uma oficina do MACBA, sem limite temporal, para que sua obra fosse estudada a fundo e classificada. Durante tal processo, foi realizada uma exposição monográfica, já em 2000, em que foram evidenciadas peças procedentes de coleções dispersas pelo mundo (BORJA-VILLEL, 2015). Além disso, foi publicado um catálogo em que foram convidados a participar Immanuel Wallerstein, sociólogo estadunidense especializado na relação entre os ciclos de movimentos anti sistêmicos, a geopolítica global e a crise do capitalismo, junto à psicanalista, crítica e teórica brasileira Suely Rolnik, que, trabalhando junto a Gilles Deleuze e Félix Guattari, formou-se na prática 
clínica da esquizoanálise (BORJA-VILLEL, 2015). Borja-Villel (2015) explica como as peças do projeto sobre Fahlström encaixavam-se entre si de maneira complexa, de modo que não se tratava de organizar uma exposição com algumas obras de arte que depois formariam parte da coleção do Museu e que seriam documentadas em um catálogo, acompanhada de atividades educativas paralelas, o que caracteriza, segundo o diretor, o funcionamento padrão de uma instituição artística, mas sim da proposição de atividades interdependentes. Borja-Villel (2015) pontua como esse projeto permitiu-lhes pensar um relato que surgia da influência mútua entre a História Política do século passado, a análise da geopolítica global, a crítica do neoliberalismo e a história das vanguardas artísticas. No que diz respeito ao MACBA, de acordo com o diretor, tratava-se de colocar em marcha um modelo para o Museu em que o departamento de Programas Públicos, os de Coleção e Exposições e o de Publicações atuassem conjuntamente em um processo reflexivo, pedagógico e crítico, em que cada seção do Museu se relacionasse organicamente com as outras, ao invés de que toda a instituição girasse em torno do fetiche dos objetos artísticos colecionáveis (BORJA-VILLEL, 2015).

\section{Ampliação e readequação da estrutura arquitetônica}

Ao assumir a diretoria do MACBA, Borja-Villel (2015) explica como percebeu que seu edifício não contava com espaços adequados para funcionarem como auditório, biblioteca e centro de documentação. Desse modo, implantar mudanças institucionais no MACBA implicou até mesmo mudar ou ampliar sua estrutura arquitetônica para proporcionar esses espaços, de modo que a instituição, como centro público, pudesse de fato desempenhar sua função política (BORJA-VILLEL, 2015).

Em 2004, foi realizada a primeira reforma funcional do Museu, que envolveu a readequação do Auditório do MACBA, no subsolo, de modo a recuperar a forma redonda do espaço, adaptar um espaço para situar os serviços técnicos, como cabines de tradução simultânea, bem como adequar a sala quanto ao aspecto acústico, para que pudesse ter uso polivalente. Outra mudança significativa foi a construção de uma entrada direta para o auditório (EL PAÍS, 2003). Em 2007, parte do complexo do Convento Dels Àngels, que data de 1566, e abarca também a Capela, foi cedido ao MACBA para a instalação do Centro de Estudos e Documentação (CED), que abriga a Biblioteca, o Arquivo e o Programa de Estudos Independentes, que surge em 2006. O espaço da Capela também foi cedido ao MACBA para ser utilizado como espaço expositivo, em 2003. Vale comentar que, em 2015, o complexo do 
Convento, que antes abrigava também a associação Foment de les Arts i el Disseny (FAD), passa a ser totalmente integrado ao MACBA, de modo a, como veremos, abrigar exposições e outras atividades (MACBA, 2015).

\subsubsection{O museu como espaço público e os conflitos internos}

Como vimos, no discurso que rege suas propostas para o MACBA, Borja-Villel tem como um dos principais objetivos dar ao Museu a capacidade de funcionar como um espaço verdadeiramente público, de modo que esse possa colocar-se a serviço da complexidade real da sociedade e ajudar a radicalizar a democracia por meio da cultura, e a fim de provocar processos mais amplos que se desdobrem para muito além da instituição (BORJA-VILLEL, 2015). No entanto, o diretor trata de destacar, no caso do MACBA, a presença do conjunto de órgãos decisórios, tanto de gestores públicos como privados, que, como vimos, integram o Consórcio. Nesse contexto, Borja-Villel (2015) enfatiza que a função de um museu público não é legitimar uma visão cultural de Estado ligada aos interesses de determinados partidos, nem deve servir para valorizar somente os interesses do establishment sobre a cultura, e, portanto, deve distanciar-se do modelo de promoção das indústrias culturais. Por outro lado, tampouco seria possível regressar aos "anos dourados" do financiamento público da cultura, de modo que, para o diretor, a defesa de que se necessita um modelo forte de instituição pública não tem a ver com reivindicar que toda a verba que sustenta os museus deva ser pública. Assim, ele assume que as instituições são lugares de conflito, não espaços estáticos nem puramente consensuais (BORJA-VILLEL, 2015).

A fim de mediar tais conflitos e, tendo aprendido com a discordância quanto à política de compras da coleção que levou à renúncia de Miquel Molins, Borja-Villel (2015) conta como optou por formar um comitê de especialistas a respeito da elaboração da coleção, formado por profissionais vinculados a instituições artísticas nacionais ou internacionais reconhecidas. Ele explica que se tratavam de profissionais afins com o projeto de sua equipe, mas que, ao mesmo tempo, caracterizavam-se por sua independência de critério (BORJAVILLEL, 2015). Diante disso, o modelo de coleção do MACBA deixava de ser uma polêmica travada apenas entre o diretor do Museu e seu patronato, situação que havia conduzido à referida crise, de modo que o comitê cumpria a função de representar um critério setorial especialista, compensando o ponto de vista particular dos membros do patronato. A existência 
do comitê evitava a ingerência de interesses partidários nas decisões sobre como ampliar a coleção (BORJA-VILLEL, 2015).

Outro ponto importante no que tange aos conflitos internos à Instituicão foi a intenção de Borja-Villel de criar o que ele chamou de "patronato desde abajo" (BORJA-VILLEL, 2015, p. 137), e que consistia em um outro comitê integrado por membros vinculados a organizações cidadãs, movimentos sociais, setores acadêmicos críticos, e até pessoas que não tinham relação direta com a arte ou a cultura, mas que estavam implicadas nas dinâmicas da cidade. A ideia era que diversas parcelas da sociedade estivessem envolvidas com as estruturas do MACBA, que até então o diretor considerava elitista, já que favorecia um exercício da direção que negociava apenas com um patronato empresarial, e de costas para a sociedade em geral (BORJA-VILLEL, 2015). Embora tal empreitada não tenha sucedido por questões legais, a alternativa adotada por Borja-Villel e sua equipe foi a de criar uma rede de colaboradores que não formavam parte nem da administração do Museu, nem da equipe fixa de funcionários, mas que estabeleciam relações com o entorno da instituição, sobretudo com a cidade de Barcelona, mas também fora dela. Ele cita, como exemplos, colaborações realizadas com a economista Miren Etxezarreta, o historiador Joan Roca, o ensaísta e ativista queer Paul B. Preciado, a historiadora argentina Ana Longoni, entre vários outros (BORJA-VILLEL, 2015). Borja-Villel (2015) explica que a intenção não era manter o MACBA em assembleia permanente e em estado de disputa entre empresários e cidadãos de fora da instituição, mas sim construir um sistema para que o Museu fosse politicamente mais inclusivo e representativo que a simples relação entre os políticos, os patronos e o diretor. Assim, tratavase de organizar diferentes áreas e situações de negociação e conflito, espaços de contato da direção com diversos setores da sociedade civil, mas sempre por meio de relações baseadas em projetos ou tarefas específicas (BORJA-VILLEL, 2015). O diretor ainda deixa claro como tinha em mente uma orientação a ser seguida pelo MACBA, mas que isso incluía construí-lo junto com outros, mediante relações de colaboração e antagonismo, sendo que se devia operar por partes, por meio de projetos e relações de trabalho concretas, a fim de que todas essas partes interagissem e mantivessem um nível de relevância horizontal, de modo que a Coleção, sobre a qual influíam o patronato e o comitê de especialistas, não tivesse mais importância que a experimentação pedagógica do Departamento de Programas Públicos, e que as exposições não fossem mais importantes que as publicações (BORJA-VILLEL, 2015). 


\subsubsection{A relação entre o público e a instituição}

Borja-Villel sustentava a ideia de que se o museu deve atuar como espaço público, o entendimento de seus visitantes como mero dado quantitativo deveria ser abandonado. Tampouco aquele poderia regressar à concepção tradicional dos visitantes como um todo impessoal ou homogêneo alheio ao conflito (BORJA-VILLEL, 2015). Os públicos deveriam então ser considerados de maneira diversa, cada um com seus interesses particulares, e cujos usos do Museu deveriam ser diferentes para cada um deles (RIBALTA, 2004). Ainda de acordo com Ribalta (2004), desse rechaço a uma concepção consensual dos públicos, aparece um modelo pedagógico em relação à cultura orientado para a experimentação de formas de auto-organização e auto-aprendizagem. O objetivo de tal método é produzir novas estruturas que possam dar lugar a formas inéditas (em rede, desierarquizadas, descentralizadas, deslocalizadas) de articulação de processos artísticos e sociais. Trata-se de dar "agência" aos públicos, de favorecer sua capacidade de ação e superar as limitações das divisões tradicionais de ator e espectador, e de produtor e consumidor (RIBALTA, 2004). O autor explica que, no MACBA, intentou-se repensar as concepções dominantes do público e experimentar com outros métodos de trabalho cultural baseado em outras possíveis formas de mediação, o que implica repensar e redefinir o público a partir das contribuições do feminismo, da teoria queer e das experiências dos novos movimentos sociais, bem como entender os públicos como transformadores e não reprodutores, superando assim as limitações da representação política tradicional, baseada em uma concepção burguesa da esfera pública (RIBALTA, 2004).

\subsubsection{Atividades realizadas durante a gestão de Borja-Villel}

Até aqui, pudemos observar algumas diretrizes que guiaram as mudanças realizadas pela gestão de Borja-Villel e sua equipe, e que objetivavam transformar o MACBA em um espaço público, aberto, acessível, de troca e reflexão, que pudesse tratar de questões prementes tanto ao âmbito local como global, envolvendo a comunidade em suas atividades e sendo por ela influenciada, além de promover a escrita de narrativas contra-hegemônicas da História da Arte. Além dos exemplos já comentados, podemos observar, a seguir, outras atividades integradas que fizeram parte desse novo projeto museográfico. 


\subsubsection{Experimentações em uma Nova Institucionalidade}

No catálogo Objetos Relacionais: Coleção MACBA 2002-2007, editado pelo MACBA em 2009, Jorge Ribalta, que ainda estava à frente do Departamento de Programas Públicos, trata das atividades às quais foram atribuídas o nome de Experimentações em uma Nova Institucionalidade. Essas foram realizadas entre 2000 e 2008, período em que a equipe do MACBA realizou vários projetos com o objetivo de reestabelecer a relação entre o Museu e a cidade, e que se estenderam desde os workshops De la acción directa considerada como uma de las Bellas Artes (2000), passando por Las Agencias (2001), ¿Cómo queremos ser gobernados? (2004), Desacuerdos (2005) e Archivo universal. La condición del documento y la utopía fotográfica moderna (2008), de modo que observaremos cada um deles detalhadamente, a seguir.

\section{La acción directa como una de las Bellas Artes}

A primeira atividade que diz respeito às experimentações dentro do Museu foi a oficina La acción directa como una de las Bellas Artes, que aconteceu no outono de 2000, e caracterizou-se como uma primeira tentativa, partindo da instituição, de unir coletivos de artistas e movimentos sociais em um mesmo projeto. Ribalta (2009) ressalta a singularidade da situação dos movimentos sociais em Barcelona nesse momento e como, desde então, o ciclo de experimentação institucional do MACBA transcorreu em paralelo e de maneira indissociável do ciclo de experimentação social desses mesmos anos na cidade. $\mathrm{O}$ diretor de Programas Públicos ainda pontua como esse momento coincide com a emergência do movimento por justiça global que eclode em Seattle em 1999, e que desencadeou a série de mobilizações que, dois ou três anos depois, deram lugar ao movimento de resistência global e antiglobalização, um movimento amplo e heterogêneo que condensava o debate sobre os efeitos negativos do neoliberalismo e o estado de caos sistêmico que o capitalismo adentrara ao longo dos anos noventa (RIBALTA, 2009).

A oficina em questão se organizava em torno de cinco áreas de trabalho, de modo que a primeira endereçava as novas formas de subemprego e trabalho precário, tendo contado com a participação de coletivos como o parisiense Ne Pas Plier, conhecido por seus desenhos aplicados aos suportes de comunicação e a intervenção em espaços públicos, realizados 
sempre em colaboração com coletivos de desempregados e subempregados da região parisiense, que trabalhou junto a grupos locais pela Renda Básica (RIBALTA, 2009).

A segunda área de trabalho tratou de fronteiras e migrações, e contou com a participação de membros da rede Kein Mensch ist Ilegal (Nada é ilegal), promovida por Florian Schneider em trabalho conjunto com organizações pelos direitos dos imigrantes ilegais e na articulação de uma crítica às injustiças derivadas da ideologia neoliberal dominante, que favorece a mobilidade do mercado e do capital, mas que restringe a mobilidade social das classes trabalhadoras e acentua as desigualdades sociais (RIBALTA, 2009).

A terceira área tratou de especulação urbanística e gentrificação, e contou com a participação dos coletivos Fiambrera Obrera de Madrid e Sevilla, grupos autônomos de trabalho voltados para a arte pública e ação urbana, cujos membros atuaram como coordenadores da oficina. Esses trabalharam junto ao coletivo Reclaim the Streets, conhecido por suas estratégias imaginativas em protestos ecologistas e intervenções carnavalescas em espaços públicos da Inglaterra (RIBALTA, 2009).

A quarta área de trabalho da oficina teve como tema os meios de comunicação. A ideia central era a de pensar maneiras de contribuir para gerar novas redes comunicativas autônomas, debate que teve origem a partir da rede Indymedia em Barcelona, que surgiu com os protestos de Seattle e converteu-se, em pouco tempo, em uma rede global do movimento. Nesse contexto, houve a intervenção do grupo RTMark, que mais tarde se transformaria nos Yes Men, e que levou suas experiências de apropriação tática e tergiversação de estratégias comunicativas corporativas (RIBALTA, 2009).

Por fim, a quinta área de trabalho tratou da questão relativa às políticas de ação direta e a questão da agência ou do empoderamento como métodos de reinventar as políticas emancipatórias ou revolucionárias (RIBALTA, 2009).

De acordo com Jorge Ribalta (2009), o objetivo da oficina foi iniciar certos processos de articulação das lutas políticas locais com métodos artísticos, de modo a manter uma continuidade e constituir uma plataforma de convergência institucional com os movimentos. Assim, entendemos-nas como ações colaborativas de reforço aos trabalhos que já vinham sendo propostos e realizados pelos movimentos sociais, e que o Museu ajudou a potencializar. 


\section{Las Agencias}

Como desdobramento da oficina La acción directa, foram desenvolvidas, na primeira metade de 2001, as oficinas do projeto Las Agencias, ainda mais complexo que seu antecessor. A seu respeito, Ribalta (2009) começa por explicar como o conceito de agência já era usado de maneira recorrente no MACBA nesses primeiros anos da nova gestão, sendo entendido em dois sentidos: um deles tinha a ver com a noção de empoderamento, ou seja, a outorga de poder e autonomia aos públicos, de acordo com uma ideia de pluralidade das formas produtivas de apropriação do museu por parte de tais públicos. O outro sentido era o de microinstituição, um organismo de mediação entre o Museu e os públicos. Desse modo, tratou-se, basicamente, da organização de oficinas e espaços que tentaram articular uma organização molecular do Museu, orientada para a multiplicação de espaços públicos e de processos de autoformação junto a diferentes coletivos que deles participaram (RIBALTA, 2009). Sendo assim, para Ribalta (2009), Las Agencias foi uma oficina permanente, um experimento de autoeducação e também a proposta de um método pedagógico baseado na premissa de que o aprendizado deriva das necesidades imediatas e é produzido em um contexto de confronto direto com os problemas e as lutas reais, além de ser o resultado da necesidade empírica de soluções efetivas para problemas específicos.

É importante entender também o contexto em que as oficinas foram realizadas, a fim de que se possa melhor compreender o impacto causado pelo projeto. Dessa forma, Ribalta (2009) destaca como o projeto foi desenvolvido nos meses anteriores ao World Bank Summit, reunião de cúpula do Banco Mundial, prevista para ser realizada em junho de 2001, em Barcelona, e que, entretanto, acabou por ser cancelada devido ao temor dos organizadores de uma reação violenta na cidade. Las Agencias aconteceu também, explica o autor, após os protestos antiglobalização em diferentes cidades como Praga e Gothenburg, quando esse tipo de protesto atingiu um momento de máxima visibilidade e influência, que chegou ao seu ápice em Genova, em julho de 2001, marcando um ponto de inflexão no ciclo de manifestações que começaram em Seattle em 1999 (RIBALTA, 2009). Entre outros motivos, os efeitos dos ataques do 11 de setembro de 2001, em Nova York, tiveram um decisivo impacto sobre a pressão política colocada sobre o movimento, como resultado de sua crescente criminalização por parte da polícia e da mídia, o que acabou por determinar sua dinâmica (RIBALTA, 2009). Para Ribalta (2009), esse momento em 2001 foi talvez o de maior dinamismo do movimento em Barcelona, de modo que, mesmo diante do cancelamento da referida reunião, foi 
organizado um protesto, tendo Las Agencias participado de maneira central nesse processo, particularmente no design de estratégias de comunicação e de perfil público que transformaram os métodos tradicionais de intervenção por parte dos movimentos anticapitalistas na cidade (RIBALTA, 2009).

O projeto foi organizado com base em cinco agências: uma agência gráfica, que produzia cartazes e material impresso para os protestos contra a reunião de cúpula, como é o caso da campanha Dinero Gratis e a produção de cartazes contra o Banco Mundial; uma agência fotográfica, que produzia imagens e um arquivo para as várias campanhas; uma agência de mídia, que foi crucial para o desenvolvimento da já citada rede Indymedia Barcelona, assim como da revista Està Tot Fatal, um instrumento de comunicação e formação de opinião dos movimentos contra a reunião de cúpula; uma agência incumbida de desenhar e produzir instrumentos para intervenção no espaço público em situações de protesto. Ainda, os envolvidos nessa agência inspiraram-se nos desenhos do Ne Pas Plier e Krzysztof Wodiczko para desenvolver projetos como Prêt à révolter, que consistia na produção de uma linha de moda para proporcionar visibilidade e segurança para os manifestantes nas ruas, e Art Mani, uma espécie de "disfarce fotográfico" para proteção contra as acusações policiais e pensados para atuar como uma fotomontagem nas páginas ilustradas dos jornais, quando fotografados. Foi organizado também o Show Bus, um ônibus adaptado para usos derivados das situações de protesto nos espaços públicos e equipados com um sistema de som e telas de projeção de vídeo, que poderia ser utilizado como espaço móvel para exposições e que permitia uma pluralidade de usos em ações públicas. Ribalta (2009) explica como esses aparatos estiveram visíveis e foram utilizados durante as manifestações de junho de 2001 nas ruas de Barcelona. A quinta agência se encarregou de gerenciar o bar do museu, que por sua vez se converteu em um "espaço relacional": não apenas um lugar para comer e beber, mas também um espaço social no qual se poderia celebrar atos com diferentes grupos e coletivos, e que contava com uma programação de vídeo e acesso à internet (RIBALTA, 2009).

Las Agencias envolveu também a organização de outras atividades como oficinas com artistas como Marc Pataut, do grupo Ne Pas Plier, Krzysztof Wodiczko e Allan Sekula. Estas se articularam de acordo com as necessidades dos grupos implicados na produção de imagens e instrumentos para as diversas campanhas (RIBALTA, 2009).

Concomitantemente às atividades elencadas, acontecia, no espaço expositivo do MACBA, a já comentada exposição Antagonismos, de caráter histórico e que apresentou uma 
série de estudos de caso de momentos de confluência entre prática artística, movimentos sociais e atividade política na segunda metade do século XX (RIBALTA, 2009).

Vale comentar também, de acordo com Borja-Villel (2015), que os projetos Las Agencias e Antagonismos foram realizados no contexto da trienal de arte Experiènces. Barcelona Art Report 2001, organizada pelos responsáveis pela Cultura da Prefeitura, uma exposição inserida no modelo de políticas culturais impostas em Barcelona desde a década de noventa, e que primavam pelos grandes eventos, os quais cumpriam com a finalidade de projetar uma imagem cultural da cidade que a fizesse atrativa ao turismo. De maneira contrária a esse modelo, foram desenvolvidos os referidos projetos, em uma empreitada que o diretor definiu como centrada em modificar a institucionalidade com a finalidade de fazê-la produzir um tipo de política não inicialmente por ela prevista (BORJA-VILLEL, 2015). O diretor discorda da ideia de que resultaria inútil intervir no campo da cultura a partir das instituições, de modo que, para ele, as decisões de cada diretor tomadas à frente de uma instituição cultural têm efeitos sobre a sociedade (BORJA-VILLEL, 2015).

\section{Procesos Documentales}

O terceiro elemento nessa constelação de atividades foi a exposição Procesos Documentales, resultado da ideia de se organizar uma exposição como forma de ação direta e como um instrumento para os protestos contra a reunião de cúpula do Banco Mundial em 2001, de acordo com as necessidades dos grupos anticapitalistas. Segundo Ribalta (2009), a exposição proporcionou uma reflexão acerca da documentação como gênero artístico historicamente construído como um gênero político, e buscou gerar reflexão e debate acerca da representação das classes subordinadas e a denúncia de suas condições precárias de vida. A hipótese sustentada pela mostra foi a de que, a fim de ter um efeito político real, a documentação requeria processos mais complexos de mediação, dentre os quais o testemunho poderia atuar como um instrumento (RIBALTA, 2009). Diante disso, a exposição apresentou uma seleção de trabalhos fotográficos e audiovisuais como base para examinar a transformação do gênero documental por meio de uma hibridização com formas de narrativa e mediação derivadas do conceito de testemunho, sob o entendimento de que se trata de um gênero narrativo que serve para tornar a voz das classes subalternas acessíveis a outros grupos sociais, por meio da figura de um mediador (RIBALTA, 2009). 
$\mathrm{Na}$ exposição, os trabalhos apresentados foram o produto de uma vontade de construir imagens que apresentassem as condições históricas e geopolíticas em que viviam grupos subalternos (RIBALTA, 2009). Para o autor, a globalização econômica e cultural e o capitalismo financeiro tinham feitos visíveis sobre a transformação de cidades e a esfera pública, que incluem o aumento da privatização dos serviços públicos, a crise nas políticas públicas de assistência social, a remodelação especulativa do espaço urbano, novas formas de exploração e precarização do trabalho, bem como a influência da ascensão das economias do serviço e do turismo sobre o modo como as cidades representam suas histórias, suplantando características identitárias singulares e substituindo-as por um simulacro da história e um “borrão indistinguível” (RIBALTA, 2009). Nesse contexto, para Ribalta (2009), era absolutamente vital que a imagem mantivesse um valor representativo e uma ética realista, a fim de que pudesse resistir à trivialização do real em mero efeito e preservar todo o seu potencial ao narrar a experiência dos processos históricos (RIBALTA, 2009).

Como efeitos desses projetos, Ribalta (2009) defende que foi gerada uma percepção pública do MACBA como um espaço para debate e crítica, o que foi demonstrado, de acordo com o diretor de Programas Públicos, pela organização espontânea, na Plaça dels Àngels, em frente ao MACBA, de uma manifestação contra a reunião de cúpula da Comunidade Europeia, em 2002, não planejada pelo Museu. Quanto a outros efeitos gerados pelos projetos, ele ressalta que a Indymedia Barcelona tornou-se uma estrutura permanente, contribuindo para a transformação dos discursos e métodos de comunicação dos movimentos sociais e, mais importantemente, os projetos contribuíram para a formação de um novo imaginário político no campo institucional, de modo que foi possível observar um novo e incipiente espaço institucional que rompeu com as geometrias tradicionais do contrato social por meio de novas formas de aliança e colaboração entre movimentos anti institucionais e o Museu (RIBALTA, 2009). Nesse contexto, Ribalta (2009) ressalta como, ao invés de os processos sociais terem sido estetizados ou desativados, foi criado um novo espaço colaborativo em que o MACBA passou a fazer parte das lutais sociais, o que, para o diretor de Programas, levou a Crítica Institucional a uma nova dimensão. Deve ser enfatizado, no entanto, que tais afirmações partem, mais uma vez, de uma perspectiva proveniente de uma figura situada no interior da instituição, de modo que não foram mensurados, aqui, os resultados dos projetos junto aos movimentos sociais. Mesmo assim, levamos em consideração, para o presente trabalho, a vontade presente, no discurso de Ribalta, de que o MACBA se aproxime e interaja com as demandas dos movimentos sociais e da comunidade. 


\section{Como queremos ser governados?}

Outra importante atividade desenvolvida no MACBA durante o período de regeneração institucional foi a exposição Como queremos ser governados?, que aconteceu em 2004. Ela foi organizada no contexto da realização do Fórum Universal de Culturas de 2004 em Barcelona, evento promovido pelo Conselho da Cidade a fim de reunir os recursos econômicos, políticos e midiáticos necessários para uma grande renovação da cidade, centrando-se sobre a orla marítima do bairro de Besòs. Para Ribalta (2009), o evento ilustrou formas de exploração da cultura para legitimar políticas neoliberais para a promoção internacional da cidade.

Diante disso, a ideia de Como queremos ser governados? surgiu de modo a oferecer um contra modelo ao Fórum de Culturas, e aconteceu sob diversos formatos em vários espaços da área de Poblenou-Besòs, nos arredores do local onde foi realizado o Fórum. Conforme explica Ribalta (2009), tratou-se de uma exposição sob a forma de processo, envolvendo um método museológico baseado em uma combinação de trabalho artístico e dinâmica social. De acordo com o diretor de Programas Públicos, a tarefa do curador, Roger Buergel, nesse contexto, foi a de dialogar com coletivos da cidade, especificamente o movimento da vizinhança da área ao redor do Besòs (RIBALTA, 2009).

Tal processo começou formalmente, de acordo com Ribalta (2009), em janeiro de 2003, a partir de uma série de debates no MACBA intitulados De les Glòries al Besòs, organizados no contexto da exposição On Translation, do artista catalão Antoni Muntadas, que envolvia uma série de debates acerca da tradução cultural que poderia ser extrapolada para as transformações em curso na cidade de Barcelona, situação imediatamente anterior ao Fórum de 2004 e em que pesavam questões como a privatização do espaço público e a perda da memória histórica na cidade. Essa iniciativa significou o início do processo de colaboração entre o MACBA e grupos locais da região de Poblenou-Besòs (RIBALTA, 2009).

A exposição Como queremos ser governados?, que se estendeu de setembro a novembro de 2004, foi apresentada, de acordo com Ribalta (2009), como um modelo alternativo e desterritorializado de museu. $\mathrm{O}$ trabalho com os coletivos locais da região do Besòs foi organizado de modo a integrar, na estrutura organizacional do MACBA, os setores politicamente ativos da sociedade civil, mas que não faziam parte da elite política e econômica que tendia a integrar os conselhos diretivos das instituições de arte (RIBALTA, 
2009). Assim, o processo de trabalho assumiu a forma de reuniões e discussões entre o curador e os coletivos locais para delinear a exposição e os projetos comissionados, os quais buscaram evidenciar lutas históricas, tais como aquelas referentes à memória do trabalho e patrimônio industrial, aos serviços e equipamentos públicos e ao trabalho precário. A exposição foi organizada como uma rota pela cidade, de modo que os espaços que a receberam abriam e fechavam sucessivamente, como um cenário em constante mudança. Tal rota foi iniciada no Institut d'Educació Secundária (IES) Barri Besòs, e teve papel essencial em fornecer serviços públicos ao distrito, além de ter atuado como local de encontro para os movimentos sociais (RIBALTA, 2009). No Instituto, foi abordada a questão do uso da exposição de arte como ferramenta de intervenção política, por meio da documentação de um ciclo histórico de exposições de arte apresentadas em espaços não artísticos. Nesse ciclo, foram retomadas e discutidas exposições como a Bienal de Arte Latinoamericana, realizada, em 1968, na sede da Confederação Geral do Trabalho de Rosário, Argentina, no contexto das experiências conceitualistas do projeto Tucumán Arde; a experiência realizada em 1989 no próprio IES Barri Besòs, no contexto de uma conferência sobre o futuro das periferias das cidades, e que marcou a fundação do movimento dos moradores do bairro e do Fórum de la Ribera del Besòs (RIBALTA, 2009). Entre outras atividades importantes realizadas no IES, no período da exposição, estiveram a mesa redonda Arte, Educación y Poder, que apresentou e debateu acerca dos métodos de trabalho artístico, os processos educativos e as formas de organização e governo, e que contou com a participação de Manuel Borja-Villel, Roger Buergel, Joan Roca, Joan Badia e Marina Subirats (MACBA, 2004); a palestra Cómo queremos ser trabajadores autónomos?, ministrada pelo teórico italiano Sergio Bologna, na qual procurou-se realizar uma reflexão acerca das mentalidades pós-fordistas nas classes médias, sobre o trabalho autônomo de segunda geração e o papel da educação na reestruturação capitalista; os debates públicos Capitalismo, globalización, ciudad, que objetivaram discutir quais formas de produzir, viver e organizar-se socialmente supunha o modelo de cidade em desenvolvimento em Barcelona à época, bem como analisar como tal modelo incidiria no tecido econômico e social, além de avaliar suas consequências para o desenvolvimento da cidade, o bem-estar da população e o processo de transformação do sistema social existente (MACBA, 2004).

O projeto seguiu então para um histórico espaço industrial chamado Palo Alto, localizado no complexo Carrer Pellaires, no qual foi representado trânsito ao pós-fordismo e à imanência neoliberal (RIBALTA, 2009). Por fim, foi ocupado o Centre Cívic La Mina, um 
centro cultural característico do planejamento urbano social democrata que ocorreu em Barcelona nos anos oitenta, localizado em um bairro que historicamente incorpora, de acordo com Ribalta (2009), as debilidades e iniquidades das políticas públicas na área metropolitana. Nesse espaço, foi apresentada a ideia do estado de exceção como norma, na forma da apresentação monográfica do projeto ExArgentina, realizado por Alice Creischer e Andreas Siekmann, cujos pontos temáticos foram a crise econômica e os levantes na Argentina realizados em dezembro dede 2001 (RIBALTA, 2009).

Por meio das atividades realizadas em cada um desses locais, buscou-se, de acordo com Ribalta (2009), promover uma leitura da história da cidade de modo a formar um contraponto ao imaginário dominante e reconstruir histórias subalternas que foram deixadas de lado e invisibilizadas pela construção hegemônica da metrópole moderna.

\section{Radio Web MACBA (RWM)}

Conforme explica Anna Ramos, que coordenou o projeto, a Rádio surgiu em 2006 e "começou como uma experiência no formato podcast" (RAMOS, 2006), tendo se transformado, "num repositório de podcasts que estende e expande as linhas discursivas e de investigação do MACBA, tendo o áudio e o sonoro como matéria-prima" (RAMOS, 2006). O objetivo inicial do projeto foi atuar como uma plataforma de divulgação da programação das atividades e exposições do Museu, condição que foi transcendida a partir da colaboração com artistas sonoros, músicos e entusiastas de rádio no desenvolvimento de séries radiofônicas. Ainda de acordo com Ramos, "a natureza web do projeto permitiu-nos assim dar visibilidade aos processos e transformar a plataforma num projeto híbrido entre o arquivo e a rádio online" (RAMOS, 2006). Trata-se de "uma forma de estender as linhas discursivas do MACBA a um local com uma arquitetura espácio-temporal alternativa, com regras e possibilidades distintas das salas e de outros espaços do Museu” (RAMOS, 2006).

\section{Outras atividades}

Foram listadas (Ver Anexo A) outras atividades, para além das já citadas e comentadas por Borja-Villel e Jorge Ribalta, que integraram e estiveram em consonância com os temas e diretrizes abordados pelo programa proposto pelo diretor e sua equipe, como seminários, oficinas e cursos que abordaram temas caros à contemporaneidade. 


\subsubsection{O elemento pedagógico na gestão de Borja-Villel}

Conforme anteriormente destacado, uma das medidas adotadas na gestão de BorjaVillel foi a substituição do Departamento Educativo do MACBA pelo de Programas Públicos, proposta que estava em consonância com a intenção de eliminar o sentido de "transmissão de conhecimento" em que muitas vezes a prática educativa estava implicada, e de modo a produzir um espaço de produção e troca de conhecimento, uma prática pedagógica radical e emancipadora, sempre de maneira horizontal. Nesse sentido, pudemos constatar a presença de tais premissas em diversas atividades como as oficinas La acción directa como una de las Bellas Artes, Las Agencias, a exposição Como queremos ser governados, entre outras, organizadas de maneira coletiva e colaborativa, com base em influxos entre o MACBA, movimentos sociais e a comunidade. Por outro lado, vale comentar que também foram realizados programas educativos direcionados a professores e alunos de educação infantil e primária, bem como segundo grau e superior, pensados a partir da coleção do Museu e também das exposições. Para os alunos, eram oferecidas visitas comentadas às exposições temporárias, e para os professores, cursos de formação, a fim de que o Museu pudesse contribuir com propostas e sugestões a serem abordadas em sala de aula. Também foi desenvolvida uma linha de trabalho sobre cultura visual dirigida especificamente ao professorado de segundo grau e nível superior. Também foram realizados projetos colaborativos com escolas, em que professores deveriam apresentar propostas ao Museu, que teria seus equipamentos disponibilizados para a realização das atividades. Aos finais de semana, eram oferecidas oficinas para o público geral, como crianças e famílias, com base nas temáticas das exposições.

\subsubsection{A recepção da gestão de Borja-Villel}

Como vimos, uma vez que neste trabalho tem se utilizado, como material de pesquisa, majoritariamente de declarações proferidas pelos diretores e profissionais envolvidos diretamente com as instituições em questão, houve o cuidado para que se pudesse destacar eventuais desencontros entre os discursos dos diretores e a forma como os projetos foram de fato recebidos pelo público, apesar da certa dificuldade em encontrar tal tipo de informação. 
No caso da gestão de Borja-Villel, Marcelo Expósito (2015) evidencia algumas críticas feitas a seu modelo de gestão, que o caracterizavam como uma aposta elitista e de difícil compreensão como conjunto. Para Cristina Garrido (2013), o MACBA havia nascido como um espaço dedicado à "alta cultura", tendência que se manteve sob a gestão de BorjaVillel. Apesar disso, para ela, o diretor ao menos fizera, junto à Jorge Ribalta, uma aposta em um programa de atividades públicas que tentou, com maior ou menor êxito, aproximar o MACBA a distintos públicos, e vice-versa, embora também ressalte como a programação foi considerada, em diversos momentos, unidirecional e não inclusiva com o tecido artístico local e com o público geral (GARRIDO, 2013).

Borja-Villel (2015) assume que, por um lado, a gestão nem sempre conseguiu comunicar e exteriorizar a complexidade do programa e dos projetos realizados, o que ele atribui ao fato de que, em grande parte, a equipe propunha atividades em resposta a urgências e situações em constante mudança, de modo que agiam de maneira rápida (BORJA-VILLEL, 2015). Ele também explica que, quando do início de sua gestão, o MACBA era uma instituição modesta em muitos aspectos, sem grande aparato para comunicar, editar ou explicar adequadamente o trabalho museográfico bastante heterodoxo que vinha sendo desenvolvido, e de modo que, durante muito tempo, o Departamento de Actividades Editoriales esteve composto por apenas dois funcionários, e, ainda que se trabalhasse com colaboradores externos, era impossível desenvolver projetos que fossem muito além das edições dos catálogos ou da publicação de diversos folhetos. Assim, o diretor explica como, com o tempo, pôde ser produzida uma coleção de livros de bolso junto ao Servei d'Edicions da Universidade Autônoma de Barcelona, e também edições online (BORJA-VILLEL, 2015).

É importante destacar também a publicação dos cadernos Ag (Agenda Informativa $M A C B A$ ), publicação trimestral lançada em 2004 com o objetivo de ampliar a oferta de espaços de debate público oferecidos pelo Museu, atuando como um espaço discursivo específico. A $\mathrm{Ag}$ tinha como objetivos comunicar a atividade do Museu e, ao mesmo tempo, oferecer ao público questões e debates, intervindo na esfera pública e marcando o ritmo do MACBA e a reflexão inerente a sua própia prática (QUADERNS PORTÀTILS, 2006).

A propósito, vale notar também a publicação de diversos ensaios, baseados em conteúdos relevantes abordados em seminários, conferências, ciclos de cinema e atividades realizadas no Museu, dentre os quais destaca-se a participação do MACBA no projeto de colaboração institucional para a publicação da revista Desacuerdos, a partir de 2004, tendo o Museu atuado junto ao centro de arte Arteleku (projeto encerrado em 2014) e a Universidade 
Internacional de Andalucía (UNIA) com o objetivo de versar sobre os vínculos entre práticas artísticas, políticas e esfera pública no contexto espanhol recente (DESACUERDOS, 2004). Vale notar também a publicação dos Quaderns portàtils, a partir de 2006, que consistem em uma linha de publicações de distribuição gratuita por meio da internet, compostos por textos procedentes de conferências e seminários realizados no MACBA, assim como de catálogos de exposições já esgotados (MACBA, s.d). Mesmo assim, de acordo com Borja-Villel (2015), durante anos não foi possível publicar o abundante material produzido por meio das atividades do Departamento de Programas Públicos, ou reflexões sobre o processo que estava sendo desenvolvido. O diretor, em retrospecto, entende que deveria ter sido colocada uma ênfase especial sobre o aspecto da comunicação, pois era essencial ao modelo que se estava criando externar o processo que vinha sendo desenvolvido, para que esse pudesse ser aproveitado mais amplamente, bem como avaliado por todos (BORJA-VILLEL, 2015).

Ainda quanto à falta de comunicação entre o MACBA e o público quanto às diretrizes propostas por Borja-Villel para o Museu, o diretor comenta, ainda, que o assunto não se encerrava apenas na edição e publicação de materiais impressos e online, de modo que envolvia um sentido muito mais amplo, que dizia respeito à criação e ampliação dos espaços de uso e reflexão coletivos, e a habilitação de mecanismos para que se pudesse exercer uma crítica que influisse no desenvolvimento de todo o processo (BORJA-VILLEL, 2015). Ele nota que essa ampliação institucional do MACBA teve início a partir dos Programas Públicos, tendo passado a ser mais ambiciosa nos últimos anos de sua gestão, de modo que envolveu principalmente o Centro de Estudos e Documentação (CEDOC), inaugurado em 2006. Em primeiro lugar, o Departamento de Publicacões passou então a ter um funcionamento mais ágil, não mais dedicado apenas a editar catálogos sobre as exposições do Museu, mas também publicações de bolso e edições gratuitas disponibilizadas online. Em segundo lugar, houve uma ampliação dos pontos de consulta, espaço e capacidade da biblioteca para reunir novos fundos bibliográficos. Em terceiro lugar, foi realizada a documentação de todas as atividades realizadas pelo MACBA, por parte do CEDOC, além da construção de um arquivo de livros de artistas, materiais impressos, revistas, mail art, etc., acessíveis a todo tipo de público, especializado ou não. Por fim, havia uma preocupação por parte do diretor de que, ao fim de sua gestão, toda uma dimensão das atividades realizadas se desvanecesse, de modo que a rede de colaboradores convocada por ele se reuniu para pensar conjuntamte uma estrutura de trabalho mais estável, o que deu origem, em 2006, ao Programa de Estudos Independentes (PEI): um programa de pós-graduação com o objetivo de formar quadros profissionais que 
exercessem o ensino ou a gestão cultural de acordo com um pensamento crítico (BORJAVILLEL, 2015). Desse modo, conforme explica Borja-Villel (2015), a pergunta que estava na base do PEI era a de como tranformar a análise das instituições não apenas em conhecimentos críticos, mas também em competências que servissem para gerir o sistema de arte de outra maneira, de um modo oposto ao que o neoliberalismo incute nas instituições culturais. Assim, ele destaca a intenção de que o modelo elaborado durante sua gestão se desdobrasse na formação de profissionais de todas as disciplinas, que pudessem exercer suas funções de maneiras alternativas à mercantilização do conhecimento que havia passado a influir no ensino superior universitário (BORJA-VILLEL, 2015). O PEI teve sua primeira edição em 2006, que contou com a direção e coordenação, respectivamente, dos professores Manuel Asensi e Xavier Antich, além da participação de professores e artistas como Enric Berenguer, Miren Etxezarreta, Marcelo Expósito, Beatriz Preciado, Carlos Prieto e Joan Roca, entre outros.

Em outra crítica, realizada no documentário $M A C B A$ : la derecha, la izquierda y los otros, Josep Miquel García, responsável pelas artes plásticas da Generalidade entre 1987 e 2001, afirma que a escolha por Borja-Villel como diretor do MACBA foi, ao mesmo tempo, uma boa decisão e uma decepção. Isso porque, para ele, Borja-Villel, com seu posicionamento internacionalista, falhou em reconhecer e exaltar importantes artistas catalães, enquanto exaltava artistas de outros países. Assim, para García, o diretor evitava a arte catalã (MACBA..., 2013).

\subsubsection{Sobre a gestão de Borja-Villel}

Até aqui, pudemos observar e compreender melhor o projeto de Manuel Borja-Villel para o MACBA, modelo que tomamos como referência para o presente trabalho, no contexto das experimentações realizadas em diversas instituições a partir do final dos anos noventa e início dos anos 2000, e por acreditarmos ter se tratado de um projeto que buscou tornar as estruturas institucionais mais porosas à participação de seus diferentes tipos de público, atuar como espaço crítico de reflexão e discussão, bem como envolver-se em questões que transpunham seus limites físicos, de modo que suas propostas abarcaram as comunidades, coletivos e movimentos sociais não apenas locais, mas também internacionais. Pudemos notar também a intenção de alterar a direção que vinha sendo tomada pelo colecionismo no Museu, ainda sem rumo ou projeto claro, e de modo a suscitar a construção de narrativas alternativas 
ao cânone da História da Arte. Isso se fez, como vimos, por meio da atenção a outros tipos de "obras", de variadas mídias e materiais, que não as obras monumentais e de grandes artistas, mais populares de acordo com a lógica do mercado, bem como pela ênfase em grupos e artistas muitas vezes menosprezados pelo cânone, e, em grande parte, cuja produção tem orientação política e ativista. Outro ponto importante do que se convencionou chamar "modelo MACBA", diz respeito, como vimos, em organizar um programa com atividades integradas e de equivalente importância.

Há que se ressaltar, no entanto, como pode ter havido, em alguns momentos, certa dificuldade do público em entender e assimilar as propostas do programa. Por outro lado, pudemos observar também a intenção em corrigir tais falhas e ampliar tais ferramentas de comunicação. Sendo assim, vale assinalar como os projetos realizado se aproximam, ao nosso ver, da possibilidade de estabelecimento de uma instituição cultural pública como espaço acessível e crítico, distanciando-se do modelo pautado unicamente pelo entretenimento e pela atração de público, sem que haja ao menos qualquer tipo de reflexão ou troca a respeito do que ali é experenciado.

Diante do exposto, prosseguimos então com a análise da gestão do curador Bartomeu Marí no MACBA, que sucedeu a de Borja-Villel, de modo que, da mesma forma, analisamos seu discurso e propostas para o Museu, bem como as atividades realizadas durante sua gestão, a fim de averiguar se essa manteve um projeto programático crítico e no sentido da continuidade das experimentações institucionais tomadas como referência no trabalho.

\subsection{A GESTÃO DE BARTOMEU MARÍ (2008-2015)}

Ao final de 2007, Borja-Villel aceita o convite para assumir a direção do Museu Nacional Centro de Arte Reina Sofia (MNCARS), em Madrid, um dos museus de arte moderna e contemporânea mais importantes do mundo, o que pode ser considerado como um reconhecimento do trabalho realizado à frente do MACBA. Em abril de 2008, Bartomeu Marí, ex-diretor do Institut Valencià d'Art Modern (IVAM) e do centro de arte Witte de With, de Roterdã, é nomeado o novo diretor da instituição. No documento Proyecto para el MACBA (2008), o novo diretor realiza um balanço da situação do Museu nos últimos anos. Ele pontua como a instituição teria alcançado uma excelente reputação, tanto na Catalunha como na Espanha, bem como internacionalmente. Marí (2008) atribui tal avaliação positiva a algumas razões: a realização de um programa de exposições originais, variadas e apresentadas com esmero e grande qualidade; a produção própria da maioria das exposições e atividades, bem 
como coproduções com instituições espanholas e internacionais de prestígio; a edição de publicações de grande interesse, com conteúdo de qualidade; a geração de um discurso singular e, em muitos casos, inédito, no panorama dos debates sobre a arte contemporânea; o desenvolvimento de uma coleção de arte contemporânea original, aberta e de alta qualidade; o alcance de uma identidade reconhecível no âmbito europeu e para além do continente (MARÍ I RIBAS, 2008). Marí (2008) ainda assinalou como considerava o MACBA único em todo o panorama institucional da Europa, destacando como o Museu estava, até então, centrado em um momento da história, os anos sessenta e setenta, fundamental para o entendimento do presente, por estar repleto de importantes rupturas com relação a elementos como a vocação da obra de arte, sua relação com o espectador, bem como o tempo e a história material (MARÍ I RIBAS, 2008). Entretanto, ele nota que outros períodos mais recentes na arte deveriam também ser abordados, como os oitenta, noventa e dois mil, a fim de que outras rupturas fossem igualmente observadas (MARÍ I RIBAS, 2008). O diretor afirma que um dos objetivos de sua gestão seria o de acrescentar às tarefas realizadas até o momento, ou seja, contribuir com o programa que vinha sendo desenvolvido, e não necessariamente substituí-lo (MARÍ I RIBAS, 2008).

Ele também alude à construção, nos anos anteriores, de um discurso de aspecto militante, ativo e não conformista pelo Museu, e que foi disseminado por meio da organização de exposições que investigaram as rupturas das práticas artísticas da segunda metade do século passado em relação aos cânones ou modelos da arte moderna. O diretor também se referiu aos projetos desenvolvidos pela gestão anterior como um programa de debates, seminários, conferências e oficinas baseadas em duas linhas de trabalho: o moderno e sua crise, e destacou como o Museu soube ordenar e tornar explícita uma posição contrahegemônica, séria e bem argumentada com relação à história recente da arte e da sociedade (MARÍ I RIBAS, 2008). Além disso, destacou como o projeto do MACBA conseguiu unir experiência estética e consciência de sujeito politicamente ativo, de modo que insistiu na figura do espectador como um ente ativo na construção dos significados e não como um receptor passivo, consumidor de conteúdos e discursos (MARÍ I RIBAS, 2008). Marí (2008) também se referiu à edificação de uma tradição pelo MACBA fortemente arraigada na figura de Borja-Villel. Diante de todos esses elementos, o desafio, para o diretor, com relação aos anos seguintes, seria o de desenvolver um novo projeto que continuasse produzindo um museu singular e de qualidade, com uma identidade diferenciada, porém sem querer imitar o passado, o que considerava impossível e desnecessário (MARÍ I RIBAS, 2008). Outro ponto 
destacado por Marí (2008) foi quanto ao papel a ser desempenhado por um museu de arte contemporânea, que, em sua visão, não deveria servir ao espetáculo ou voltar-se para o acúmulo monetário, mas sim ajudar os membros da sociedade a realizarem questionamentos e a tomarem decisões (MARÍ I RIBAS, 2008).

Ainda no balanço inicial, Marí (2008) referiu-se às exposições temporárias como o motor principal da atividade do Museu. Ele destacou a intensidade de seu programa e a característica distintiva de alternar exposições monográficas e de tese, de modo que as primeiras teriam, a seu ver, garantido a presença de artistas importantes para a arte contemporânea e pouco conhecidos pelo grande público, enquanto as últimas teriam feito contribuições valiosas para sua apreciação (MARÍ I RIBAS, 2008).

Para o diretor, se o MACBA era essencialmente um "cubo branco" do ponto de vista arquitetônico, esse deveria esforçar-se para ampliar seu vocabulário expositivo para além da dicotomia cubo branco/caixa preta, de modo que seus espaços acolhessem obras e apresentações que se aproveitassem de um espaço que Marí julgava parcialmente desaproveitado (MARÍ I RIBAS, 2008).

Outro ponto levantado por Marí (2008) dizia respeito à (sub)utilização dos espaços expositivos do Museu: ele pontua como o MACBA contava com dois tipos de espaços igualmente determinantes: o cubo branco, projetado pelo arquiteto Richard Meier, e a arquitetura histórica da Capela de los Ángeles, de modo que assinalou a importância da exploração intensiva e inventiva dessas duas tipologias de espaços. Nesse contexto, para o diretor, os trabalhos in situ haviam sido pouco explorados até então e mereciam ser melhor considerados (MARÍ I RIBAS, 2008).

Foi notada também por Marí (2008) a importância da relação do MACBA com outros espaços de arte contemporânea, dentre os quais o diretor destacou o Palau de la Virreina, o Centre de Cultura Contemporània, o Centre d'Art Santa Mònica e a Fundació Antoni Tàpies, bem como com os diferentes coletivos de produtores artísticos e de pensamento, além da rede de centros de arte criados na geografia catalã. Assim, para ele, em 2008, o presente e o futuro do MACBA passavam por manter e melhorar seu status de instituição de vanguarda no território catalão, bem como por encontrar maneiras de alinhar-se a outras instituições de qualidade com as quais se relacionava em termos de competência e complementariedade. Outro ponto destacado diz respeito à necessidade de solidificação da relação entre o MACBA e as instituições acadêmicas, com as quais se deveria contribuir para a criação de conhecimento e o que dependia, essencialmente, da manutenção de melhora de seu papel no 
contexto internacional, dentro do qual, para Marí (2008), havia muitos desafios significativos. Assim, para o diretor, por mais que a Europa fosse o âmbito natural de ação do Museu, era também necessário que as regiões mediterrâneas fossem exploradas e se conectassem culturalmente (MARÍ I RIBAS, 2008). Ele também se referiu à América do Sul e à Europa Oriental, territórios com situações culturais específicas que começavam a formar parte da coleção e do programa de exposições do Museu timidamente e que mereciam mais atenção (MARÍ I RIBAS, 2008).

\section{A Coleção}

Com relação à Coleção do MACBA, Bartomeu Marí (2008) argumenta que a consistência lógica de suas partes históricas parecia debilitar-se no que dizia respeito a obras de artistas de gerações mais jovens, de modo que estavam praticamente ausentes os discursos de grande interesse que se desenvolveram nos anos oitenta e noventa no contexto internacional. Marí (2008) exemplifica que, se até aquele momento, tinha-se a ideia de que os anos oitenta estavam dominados unicamente pela pintura expressionista, havia a necessidade de se valorizar a produção escultórica e a normalização do uso da fotografia, que precedem a ficção e a narração como material de arte dos anos noventa (MARÍ I RIBAS, 2008).

O diretor defendeu também, em suas propostas, que o desenvolvimento da coleção do Museu deveria ser orgânico e coerente com o que havia sido realizado até aquele momento (MARÍ I RIBAS, 2008). Dever-se-ia, enfatizou, continuar a aposta em sua singularidade e não cair nos caminhos transitados por outros museus, além de não se pretender generalista, mas sim aprofundar-se quanto às especificidades até então cultivadas, bem como iniciar outras (MARÍ I RIBAS, 2008). O diretor pontuou que, se por um lado o Museu enveredou-se pelo terreno de colecionar documentos que funcionam como obras de arte, tais quais os de coletivos como Grup de Treball, Tucumán Arde, entre outros, não havia que se rechaçar a coleção de grandes obras de artistas significativos de nosso tempo. Marí (2008) sugeriu, além de que fosse mantida a atenção sobre os pontos fortes da coleção do Museu, os anos sessenta e setenta, que se ampliassem as contribuições de artistas singulares. Para o diretor, deveriam ser estabelecidas novas colaborações com museus para a aquisição de obras emblemáticas de artistas-chave, como foi o caso de Shapolski et. Al., de Hans Haacke, adquirida juntamente com o Whitney Museum of American Art de Nova York (MARÍ I RIBAS, 2008). 


\section{Publicações}

A respeito das publicações do MACBA, Marí (2008) pontuou que as considerava instrumentos essenciais para a construção de memória própria, além de ressaltar sua importância para a documentação, comunicação e formação. Ele cita os catálogos de exposições e publicações discursivas, além da produção de conteúdo para internet (MARÍ, 2008). No entanto, o diretor assinalou e criticou a dependência das publicações com relação ao ritmo de preparação das exposições, de modo que propôs que a especificidade de cada publicação fosse trabalhada com mais atenção, o que, por sua vez, necessitaria uma dedicação mais atenta, um calendário de produção mais generoso e uma implicação mais produtiva dos autores de cada projeto (MARÍ I RIBAS, 2008). Para ele, a falta de publicações que refletissem a complexidade e a dimensão da coleção do Museu era uma prova dessa necessidade. Desse modo, além das edições volumosas sobre a coleção, para Marí (2008), o MACBA poderia desenvolver uma política editorial quanto a seu patrimônio de maneira mais específica em torno dos artistas e obras-chave da coleção.

\section{Programa de Estudos Independentes (PEI)}

Marí (2008) tratou também da importância do PEI, que teve continuidade em sua gestão, na organização de seminários, debates e conferências, que considerava dotados de relevância qualitativamente equiparável aos estudos universitários, porém independentes da rigidez dos currículos acadêmicos. Segundo ele, a força do PEI estava precisamente em sua abordagem de temas e campos de debate que as universidades não contemplavam, sendo que, para ele, a centralidade dos debates sobre a criação artística, a história da arte e o programa de exposições do MACBA deveria ser evidente (MARÍ I RIBAS, 2008). Para o diretor, o PEI não ilustrava necessariamente o programa de exposições e a Coleção, mas, na medida do possível, os precedia. O objetivo do PEI tinha, para Marí (2008), dois sentidos: contribuir para formar uma nova cultura da História da Arte desde o âmbito dos estudos especializados e alimentar o Museu com a produção de conhecimento sobre os temas que lhes interessava desenvolver. Para ele, tratava-se de um instrumento que funcionava dentro de uma rede de relações e que constituía uma ferramenta essencial na relação do MACBA com seu entorno intelectual (MARÍ I RIBAS, 2008). 


\section{Centro de Estudos e Documentação (CEDOC)}

O diretor fez considerações a respeito do Centro de Estudos e Documentação (CEDOC), que abriu suas portas em dezembro de 2007, e representava uma aposta estratégica essencial para o projeto do MACBA, de modo a situá-lo como produtor de conhecimento (MARÍ I RIBAS, 2008). Para Marí (2008), o CEDOC deveria ser complementário ao PEI, assim como aos outros âmbitos, como exposições e publicações. O diretor menciona também o arquivo de Oyvind Fahlströmn, localizado no MACBA e que deveria ser ativado como um exemplo do tratamento que o Museu outorga ao arquivo do artista como instrumento importante no conhecimento e reescrita da arte em nosso tempo. Além disso, para Marí (2008), os arquivos do MACBA deveriam manter uma complementariedade com outros arquivos, assim como uma atenção às técnicas digitais, de modo a otimizar o espaço de armazenamento dos documentos.

\section{Educativo}

Quanto à ação educativa do Museu, Marí (2014) apostava em duas propostas: uma realizada junto às escolas, e outra com os visitantes em geral. Salientou também que, nas escolas, o MACBA incidiria na formação do professorado, enquanto que, com relação ao público geral, seria trabalhada e desenvolvida a tecnologia da visita guiada, que considerava um dos melhores instrumentos educativos, devido ao contato direto com as obras de arte (MARÍ, 2014). O diretor ainda destacou que a educação não era algo que pudesse ser reduzido às escolas, mas sim uma transformação realizada por todos, a todo momento. Ainda, para Marí (2014), era muito importante ver o museu e as experiências de arte como uma maneira de alfabetização visual ou sensitiva, em um mundo em que os códigos visuais e estéticos se alteravam cada vez com maior rapidez.

\subsubsection{Atividades desenvolvidas a partir da gestão de Bartomeu Marí}

Aqui analisamos as atividades desenvolvidas dentro dos programas do MACBA durante a gestão de Bartomeu Marí como diretor, ou seja, entre abril de 2008 e março de 2015, a fim de verficarmos uma continuidade, ou não, na realização de experimentações institucionais, bem como possíveis mudanças de direcionamento nos programas realizados. 
Uma vez que observamos, no discurso de Bartomeu Marí, a intenção em contribuir com o programa desenvolvido na gestão anterior e não necessariamente substituí-lo, analisamos as atividades desenvolvidas em sua gestão tomando como parâmetros as diretrizes estabelecidas na gestão de Manuel Borja-Villel. No entanto, também podem ser observadas mudanças e acréscimos ao programa do Museu a partir da gestão de Marí e seus colaboradores, como a ampliação do uso dos espaços expositivos do MACBA, como o Convento e a Capela, a abordagem, na Coleção e nas exposições, de períodos mais recentes na arte, como os oitenta, noventa e dois mil, e o projeto de "reset" proposto por Marí junto à Valentín Roma e Paul B. Preciado a partir de 2014.

\section{Quanto ao debate político no Museu}

Ao analisar as diversas atividades propostas ao longo da gestão de Bartomeu Marí, destacamos, de início, a realização de seminários, mesas redondas, cursos e afins, voltados para o público geral, ministrados por importantes profissionais, acerca de temas relevantes à contemporaneidade, e que se enquadram na proposta de Borja-Villel de "introduzir o político no Museu" (Ver Anexo B).

Como exemplos, podemos citar seminários como: Después del Neoliberalismo: Ciudades y Caos Sistémico, realizado em novembro de 2008, e que contou com a participação do coletivo Observatorio Metropolitano, o arquiteto Eyal Weizman, o escritor Mike Davis e a arquiteta e pesquisadora Raquel Rolnik (MACBA, 2008a); Conocimiento Contra el Capitalismo Financiero, organizado pelo MACBA em colaboração com a Escuela Europea de Imaginación Social, em dezembro de 2011, e coordenado por Francesco Berardi, em que artistas, filósofos e poetas foram convidados a imaginar un futuro livre do dogma da especulação financeira (MACBA, 2011a); Sobre Crédito, Autoestima y Sharing: Introducción a la Condición Neoliberal, realizado em dezembro de 2011, ministrado pelo filósofo Michel Feher, e que pretendeu analisar a condição neoliberal nos âmbitos da governança corporativa, da política governamental e das redes sociais (MACBA, 2011b); Ocupar, Desbordar y Cooperar - Encuentro de Saberes sobre la Nueva Onda Global, cujo propósito foi traçar certos eixos temáticos em relação às gramáticas do protesto, às políticas expressivas, às críticas da representação e às experimentações organizativas, a partir de casos de estudo como os movimentos Occupy, $15 \mathrm{M}$ e os movimentos estudantis em países como Chile, Colômbia, México e Canadá, com a participação de Franco "Bifo" Berardi, Isabell Lorey, 
Gerald Raunig, Nicolás Sguiglia e a Plataforma de Afectados por la Hipoteca (PAH) (MACBA, 2013a); Imaginarios postcoloniales de África, realizado em fevereiro de 2013 e dirigido pelos historiadores da arte T.J. Demos e Hilde Van Gelder, que combinou um debate sobre a condição pós-colonial com a apresentação de documentários por autores como Herman Asselberghs, Sven Augustijnen, Renzo Martens e Els Opsomer (MACBA, 2013b); El Ballroom tiene algo que decir sobre el ser humano y la lucha por la libertad, ministrado pelo téologo queer e ativista Michael Roberson, em dezembro de 2013, sobre a cultura Ballroom originada no Harlem, em Nova Iorque (MACBA, 2013c).

Quanto às mesas redondas, destaca-se: Nuevos Derechos, Movimientos Sociales y Modelo de Ciudad, realizada em outubro de 2008, por ocasião da publicação de París, capital de la modernidad, de David Harvey (MACBA, 2008b); Mesa redonda Reconstruyendo Office Baroque: en la Lógica del Turismo Urbano, na qual, em junho de 2012, a partir do filme Office Baroque, de Gordon Matta Clark, procurou-se debater a atualidade das relações entre a arte contemporânea, o turismo cultural e a identidade urbana (MACBA, 2012a).

Podemos ainda citar, entre as atividades que buscaram suscitar, debater e refletir sobre questões urgentes no panorama contemporâneo, o curso El Arte Tras los Femenismos: Hacia una Historiografía Postfemenista del Arte Contemporáneo, ministrado pelo teórico e curador trans Paul B. Preciado entre março e abril de 2008 (MACBA, 2008c); Laboratório Museo Molecular. ¿Es Posible la Gestión Desterritorializada y en Red del Patrimonio Cultural? realizado em junho de 2008 como parte do Programa Translate. Beyond Culture: The Politics of Translation do European Institute for Progressive Cultural Policies (EIPCP), com objetivo de pensar um novo tipo de institucionalidade e um tipo de museu pós-colonial (MACBA, 2008d); a palestra Obama, el Mundo y la Construcción de Otro Mundo Posible, ministrada, em janeiro de 2009, pelo sociólogo estadunidense Immanuel Wallerstein, no contexto dos seminários El arte de la crisis. Seminarios sobre la crisis sistémica del capitalismo, organizados pelo Centro de Arte Reina Sofía e o projeto Universidad Nómada, com a colaboração do MACBA (MNCARS, s.d); o encontro com a escritora, professora e ativista feminista Silvia Federici, em maio de 2012, acerca dos contínuos processos de expropriação dirigidos aos corpos, saberes e à reprodução das mulheres (MACBA, 2012b); a jornada Sexualidad, culpa y lo real, realizada, em julho de 2012, em colaboração com a Universidade Autônoma de Barcelona (UAB), cujo objetivo foi a formação de um espaço de diálogo plural e diverso de pensamento do feminino arraigado na experiência e, em particular, na representação da experiência gerada desde o corpo em relação à diferença sexual, e que 
contou com uma oficina de pesquisa na UAB e uma conferência no Auditório do MACBA, ministrados pelas professoras Alenka Zupancic e Joan Copjec (MACBA, 2012c).

\section{Quanto à modificação da narrativa sobre a História da Arte por meio da Coleção e do programa de exposições}

Quanto ao que Borja-Villel caracterizou como a proposição de narrativas contrahegemônicas da História da Arte, a partir de mudanças promovidas na formação da Coleção do Museu e de seu programa de exposições, pudemos observar, na gestão de Bartomeu Marí, iniciativas nesse sentido (Ver Anexo C). Entre elas, destacamos: a exposição Tiempo como matéria, de 320 obras da coleção MACBA, entre maio e agosto de 2009, que apresentou as novas linhas de interesse e investigação prioritárias que o MACBA passou a adotar a partir de 2008, buscando formar uma coleção que explicasse a passagem do século XX ao XXI, ao tratar das formulações das últimas utopias do século passado e sua crise, também abordando o presente, com suas complexidades e contradições. Na exposição, foram apresentadas as obras adquiridas pela Coleção MACBA ao longo dos dois anos anteriores. Foram exibidas obras como Shapolsky et al. Manhattan Real Estate Holdings, a Real-Time Social System, as of May 1, 1971, adquirida, como vimos, em 2007, juntamente ao Whitney Museum of American Art de Nova York; grupos de obras de Pablo Palazuelo e de Gego, depositadas no MACBA, respectivamente, pela Fundação Pablo Palazuelo, de Madrid, e a Fundação Gego, de Caracas. Destacam-se também importantes doações como

de cinco obras de León Ferrari, realizadas nos anos oitenta, além da doação dos murais fotográficos Shipwreck and Workers (2005-07), por Allan Sekula (MACBA, 2009a).

Destaca-se também a apresentação, entre julho de 2010 e janeiro de 2011, de obras selecionadas e até então nunca expostas da Coleção, em que os critérios tradicionais de ordem cronológica foram voluntariamente substituídos, em benefício de uma disposição de caráter mais flexível e fluido. Desse modo, a contiguidade, em um mesmo espaço, de obras e autores semelhantes, seja por geração, materiais e formatos, discurso, escola, ideias compartilhadas ou vínculos de amizade entre os artistas, entre outros critérios, respondeu ao objetivo de potencializar um percurso que fosse liberado da disciplina historicista, com ela rompendo e convidando o público a estabelecer relações mais complexas, aleatórias, sugestivas e livres (MACBA, 2010a); a exposição de obras selecionadas da Coleção MACBA sob o título 
Moderno y Presente - Cambio de Siglo en la Colección MACBA, em exibição de fevereiro a setembro de 2011, que partiu da tese de que a eclosão estética da modernidade na Catalunha teve lugar a partir de 1950, e não no princípio do século XX, como ocorreu em outros países da Europa (MACBA, 2011c); a mostra Episodios Críticos (1957-2011). Colección MACBA, em exibição entre novembro de 2012 e fevereiro de 2013, que tratou das periódicas crises da arte contemporânea, desde os anos sessenta, sugerindo os antecedentes do que atualmente se considera uma crise sistêmica, e de modo a construir um itinerário de momentos críticos (MACBA, 2012d).

Algumas exposições temporárias também buscaram oferecer alternativas ao cânone da História da Arte, como Modernologías - Artistas Contemporáneos Investigan la Modernidad y el Modernismo, em cartaz entre setembro de 2009 e janeiro de 2010, cujo objetivo foi questionar as condições e os limites da modernidade e do modernismo, bem como revelar novas interpretações e "modernismos desconhecidos" em países a cujos protagonistas haviam sido designados papeis até então marginais no que diz respeito a essa temática (MACBA, 2009b); Arte, dos puntos - Barcelona Vive el Arte Contemporáneo, em exibição entre julho de 2013 e janeiro de 2014 e produzida pelo MACBA junto à Fundação La Caixa, que buscou ampliar o conjunto de narrações sobre o passado recente e oferecer ao visitante melhores condições para entender a contemporaneidade, percorrendo as tensões que atravessaram a modernidade e a vanguarda e confrontando obras e documentos do passado com a criação e as linguagens contemporâneas (MACBA, 2013d).

Também com o objetivo de promover narrativas alternativas ao cânone da História da Arte, foram realizados seminários e conferências (Ver Anexo D), tais como: A mesa redonda La Historización de los Setenta, realizada em março de 2012, a propósito da exposição Centre Internacional de Fotografia Barcelona (1978-1983), que propôs repassar e questionar alguns dos tópicos dominantes e recorrentes na historicização do período da Transição Espanhola, como a centralidade da revista Nueva Lente, a naturalização de um discurso sobre a incorporação da fotografia no sistema artístico, o relato sobre a ruptura geracional dos setenta e o novo protagonismo da "quinta geração", tópicos explicativos do período, que, porém, geram suas próprias exclusões e pontos cegos que deveriam ser expostos e explorados (MACBA, 2012e); o ciclo de seminários Las Derivas de la Teoria. La Periodización del Arte Contemporáneo, ministrado por Peter Osborne em abril de 2012, que pretendeu avaliar a vigência dos conceitos, problemáticas, antagonismos e debates que marcaram a década de oitenta e apontar possíveis vias de renovação, em um momento em que as posturas que 
outrora pareceram radicais, passaram a encontrar-se comodamente instaladas nos âmbitos acadêmicos (MACBA, 2012f).

Já a exposição Museo de Narrativas Paralelas - En el Marco de la Internacional disse respeito à necessidade, destacada por Bartomeu Marí, de se abordar a produção artística da Europa Oriental. A exposição, realizada de maio a outubro de 2011, reuniu mais de uma centena de obras de cerca de setenta artistas que traçavam um panorama da arte de vanguarda dos países da Europa do Leste, desde 1961 até a atualidade. A maioria das peças formava parte da Coleção Arteast 2000+ da Galeria Moderna de Ljubljana, sendo que também foram apresentados sete projetos específicos para a exposição, sendo quatro sobre auto-historização e a criação de arquivos paralelos (realizados por Artpool, Július Koller, Zofia Kulik e Lia Perjovschi), e três sobre microcoleções fictícias, nas quais se estabeleciam conexões entre artistas ocidentais e orientais (apresentados por Alexander Dorner, IRWIN e Mladen Stilinović) (MACBA, 2011d). Com o mesmo objetivo, vale comentar a respeito da exposição Series militares. Aleksandr Sokurov en la Colección MACBA, que abordou a filmografia do cineasta russo, considerada imprescindível para o entendimento da complexidade que encerra a história da Rússia pós-soviética (MACBA, 2012g).

\section{Atividades realizadas pelo programa PEI Aberto}

A fim de promover atividades que debatessem temas políticos no Museu e tratassem de descontruir narrativas hegemônicas, pudemos observar, no item anterior, propostas significativas. Da mesma forma, notamos a proposição de atividades nesse sentido por parte dos integrantes do PEI, por meio do programa PEI Aberto. Esse compreende as atividades abertas ao público programadas pela equipe do Programa em diversos formatos, como debates públicos, seminários, oficinas, programas audiovisuais e conferências, que compartilham e dão visibilidade às linhas de investigação desenvolvidas pelo PEI e se articulam com o programa de exposições e atividades do MACBA. Como vimos, o PEI originou-se na gestão anterior como uma forma de continuar as discussões por ela iniciadas, manter ativa a rede de colaboradores criada para dinamizar a questão da participação dentro da instituição, e de modo a fundir pesquisa teórica e prática, treinamento acadêmico, interação social e intervenção cultural. Como exemplos das atividades organizadas pelo PEI durante a gestão de Bartomeu Marí, tivemos diversos seminários (Ver Anexo E), que abordaram temas como subalternidade e representação; a crise da AIDS, arte e guerrilha contrabiopolítica; como 
repensar as organizações culturais diante das novas relações entre arte e economia; os relatos feministas, queer e trans frente à historiografia da arte, entre outros. Destaca-se também o projeto Museo Oral de la Revolución, realizado de novembro a março de 2013 e concebido por Paul B. Preciado, realizado com a pesquisa e colaboração dos alunos do PEI (edição 2012-2013). A ideia foi realizar um arquivo-exposição performativo e sonoro que buscava tornar audíveis e especializar, no contexto da cidade e do museu contemporâneos, as linguagens de transformação social inventadas pelas minorias raciais, de gênero, sexuais, corporais e da diversidade funcional e cognitiva: desde a primeira revolução de escravos no Haiti e as revoltas de citoyennes até os atuais movimientos queer, autistas, interssexuais, transgêneros, antiespecistas e outros, que lutam para ampliar e redefinir os límites do horizonte democrático. O projeto ainda objetivou colocar em questão a hegemonia da observação passiva e silenciosa do visitante do cubo branco que domina o museu contemporâneo, de modo que, frente à exposição tradicional, propôs a criação de um espaço escuro no qual se intensificaram as experiências da escuta e a enunciação de atos de fala, de modo a explorar o conhecimento oral, a função da teatralidade no ativismo, as relações entre linguagem e ação, a especificidade semiótica e pragmática dos enunciados políticos, assim como as relações do gênero literário do "manifesto" como práticas artísticas de vanguarda e conceituais. Entre as atividades do projeto, foram realizadas: a oficina de leitura Sí, Manifesto, que visou recuperar a força disruptiva e propositiva dos manifestos, panfletos e outros formatos de enunciação política, cujas preocupações passaram pela dissidência sexual, a diferença mestiça e o feminismo negro, por meio de uma dinâmica participativa, orientada a ativar a força da enunciação; a oficina Al Oral!, coordenada pelo artista Javier Peñafiel, em que foram trabalhados textos do arquivo MOR, criado pelo PEI, em numa dinâmica de “nudez-volume". Destaca-se também Actos de Habla, definido como um teatro político e poético em que se buscou tornar audíveis as linguagens minoritárias, no qual os alunos do PEI, em colaboração com artistas e ativistas, criaram coletivamente um laboratório em que buscaram reinventar a esfera pública por meio da fala e da escuta. Assim, frente ao modelo hegemônico de espectador visual silencioso que domina o museu moderno, foi proposta uma multiplicidade de sujeitos políticos, corpos e linguagens, bem como modos de conhecer e experimentar que vão além da visão, e que se construem por meio da conversação e do tato. Como parte dessa proposta, foi realizado o projeto Solange, tô aberta, de Pedro Costa, em formato de show, estilo baile funk, que mesclou queer, punk, drag e pós-pornô com o som do funk carioca, utilizado como uma ferramenta política de resistência. Também dentro dos 
Actos de Habla foi realizada a intervenção Matar el miedo, em que cinco participantes leram uma seleção de manifestos do alto das varandas de três pontos estratégicos do Raval, com o propósito de construir, mediante un ato poético-político, uma relação solidária entre artistas, agentes culturais e vizinhos do bairro, em um gesto de resistência à violência policial e às políticas de vigilância sexual e racial (MACBA, 2013e).

\section{Exposições monográficas}

Assim como na gestão de Borja-Villel, também foram realizadas, durante a de Bartomeu Marí, exposições monográficas que visaram difundir a obra de artistas importantes no âmbito da arte contemporânea, e nem sempre conhecidos pelo grande público (Ver Anexo F). Como alguns exemplos temos: a exposição Disidanzas, retrospectiva da obra da artista estadunidense Nancy Spero (MACBA, 2008e); Da Capo, retrospectiva da obra do artista catalão Francesc Torres, pioneiro da linguagem de instalação (MACBA, 2008f); a exposição Cildo Meireles, de trabalhos produzidos pelo artista brasileiro entre 1967 e 2008 (MACBA, 2009c). Pudemos observar também o destaque para exposições de artistas catalães, como nas exposições Joan Rabascall. Producción 1964-1982; En el Laberinto - Àngels Ribé 19691984; Lejos de los Árboles. Jacinto Esteva en la Colección; Motor de Modernidad - Grup R. Arquitectura, Arte y Diseño; Nitrato, de Xavier Ribas; Tàpies como Síntoma - Una modernidad Sin Correspondencia; bem como exposições que abordaram acontecimentos importantes no contexto espanhol, da região e da cidade de Barcelona, como La Utopía es posible. ICSID. Eivissa, 1971, sobre o VII Congreso do International Council of Societies of Industrial Design (ICSID) que aconteceu em Ibiza, em 1971, concebido como um ponto de confluência entre o design e as formas mais experimentais da arte e da arquitectura da época no país (MACBA, 2012h); e Le Corbusier y Jean Genet en el Raval, que abordou as experiências do arquiteto e do escritor, respectivamente, no bairro em que o MACBA está localizado (MACBA, 2012i).

\section{Exposições de tese}

As exposições de tese, como vimos, foram peça importante da gestão Borja-Villel, sendo que também tiveram espaço na gestão de Marí. Ele destacou, nesse sentido, a exposição Archivo Universal. La condición del documento y la utopía fotográfica moderna, realizada 
em outubro de 2008, centrada na noção de documento fotográfico, e que serviu para formular duas grandes perguntas: "Que sentido tem, na atualidade, o documento fotográfico?" e "Como nos relacionamos com os lugares e com aquilo que as imagens representam?" (EL CULTURAL, 2008). Outro exemplo foi a exposição Modernologías, que, de acordo com o diretor, pretendeu revisar os anos oitenta, desde a revolução iraniana de 1979 até a queda do muro de Berlim, em 1989, e a herança da modernidade na prática artística contemporânea (LA RAZÓN, 2009).

Vale ressaltar que, em 2011, o MACBA e outras instituições culturais de Barcelona sofreram cortes orçamentários, de modo que o Museu passou a contar com uma verba 5,24\% menor que a do ano de 2010, e 11,8\% menor que em 2008, passando a operar com 12,1 milhões de euros (SESÉ, 2010). Diante disso, Bartomeu Marí (2012) explicou que foi reduzido o número de exposições, as quais se tornaram mais extensas, e nem todos os projetos expositivos foram acompanhados de publicações, sendo que também houve uma diminuição das exposições de tese e monográficas de grande investimento, de modo que o foco passou a ser as obras da própria coleção do MACBA e o CEDOC (GARCÍA, 2012).

\section{Articulação entre as exposições, a coleção e as atividades de Programas Públicos}

No que tange à articulação entre as exposições, a coleção e as atividades de Programas Públicos, outra diretriz da gestão Borja-Villel, pudemos observar, durante a gestão de Bartomeu Marí, diversas atividades como visitas guiadas, oficinas, seminários, palestras, mesas redondas, mostras cinematográficas e cursos, de modo a abordar de diversas formas os temas propostos pelas exposições. Desse modo, vimos que, geralmente, as exposições partiam como ponto inicial para a realização de outras atividades concomitantes, a respeito dos temas por elas levantados. Como exemplos temos:

\section{Visitas guiadas para o público geral}

Foram realizadas diversas visitas guiadas a exposições para o público geral, podendo ser realizadas por curadores, co-curadores, pelo diretor Bartomeu Marí e, muitas vezes, com a participação dos artistas, sendo que algumas das visitas eram exclusivas aos Amigos MACBA. Podemos citar, como exemplos: visitas abertas ao público à retrospectiva John Baldessari. Pura belleza, sob a perspectiva de diferentes profissionais, como artistas, 
educadores, críticos de arte e curadores (MACBA, 2010b); El espacio desbordado. Otras maneras de visitar una exposición, que consistiu em visitas à exposição Dorothee y Konrad Fischer. Archivos de una actitud (MACBA, 2010c); visitas do programa Modernos y Contemporáneos. Diálogos Intergeracionales, que buscou, por meio da aproximação às exposições do MACBA, tratar de arte e cultura contemporânea entre membros de diferentes gerações (MACBA, 2014a).

\section{Visitas familiares às exposições}

Verificou-se também a realização de visitas familiares em torno das exposições, em que se destaca o programa MACBA em família, que, aos finais de semana, oferecia uma programação permanente dirigida ao público familiar, nas quais se combinavam visitas às salas de exposição com oficinas e sessões de cinema, de modo a envolver o público geral em atividades de aproximação com a arte e a fim de explorar as temáticas propostas pelas exposições. O objetivo do programa foi proporcionar um espaço no qual se pudesse aprender conjuntamente de forma lúdica, bem como descobrir propostas artísticas não apenas agradáveis esteticamente, mas que incitassem a reflexão sobre as muitas maneiras de fazer, olhar e escutar a arte de nosso tempo. Como alguns exemplos de atividades do programa, notamos: Cuestiones de Espacio, oficina que propôs analisar os espaços físicos, temporais e mentais ocupados pelas obras expostas no Museu (MACBA, 2010d); Por los Laberintos de Àngels Ribé (setembro de 2011), oficina que abordou a obra da artista Àngels Ribé, por ocasião da exposição de seus trabalhos (MACBA, 2011e); ;Hula! Juego, Performance y Acció, oficina realizada no espaço da Capela MACBA no contexto da exposição das esculturas em vídeo de Sigalit Landau, cujos elementos chave foram o corpo, o movimento e o trabalho em equipe (MACBA, 2015a); a atividade ¿Qué es el MACBA?, um percurso pelas salas do Museu que propôs uma aproximação lúdica e interativa à arte contemporânea (MACBA, 2015b).

Aos sábados do mês de dezembro de 2012, foi organizado o programa MACBA Se Vive, em que o Museu prolongou seu horário habitual de funcionamento até as nove da noite, de modo que, no período entre as $18 \mathrm{~h}$ e as $21 \mathrm{~h}$ era oferecida uma programação com música, dança, ações artísticas e conversas nas salas de exposição. Também foram organizadas visitas especiais que abordaram os processos de conservação das obras, a arquitetura do edifício ou o mundo das performances. O programa contou com atividades como as desenvolvidas pelo 
coletivo Les Salonnières, que trabalhou as questões do entorno a partir do corpo e da atitude, além de realizar intervenções que questionaram pensamentos pré-estabelecidos sobre a identidade pessoal e coletiva (MACBA, 2012j).

\section{Oficinas e visitas-ateliê}

Foram realizadas oficinas-ateliê junto ao público geral, a partir dos temas suscitados pelas exposições, tais como: oficina de desenho em torno da exposição Disidanzas, de Nancy Spero (MACBA, 2008g); oficina a propósito do projeto Atlas, idealizado pelo coletivo de artistas alemão Creischer/Siekmann, e cujo resultado consistiu na inclusão de um painel feito pelos participantes na exposição Modernologías (2009) (MACBA, 2009d); oficina para crianças Tiempo como matéria, baseada nas obras de Palle Nielsen, Peter Friedl e Öyvind Fahlström da Coleção MACBA (MACBA, 2009e); Todo lo que nos rodea es música, visitaateliê realizada em torno da exposição La anarquía del silencio. John Cage y el arte experimental (MACBA, 2009f); Audición de Poesía Sonora, oficina realizada a propósito da exposição do artista Gil J Wolman (MACBA, 2010e).

Nota-se também o projeto realizado, entre junho de 2010 e abril de 2011, no contexto da exposição ¿Estáis listos para la televisión?, oferecido para estudantes do segundo grau e universitários, e dividido em três partes: a visita à exposição, a participação no debate e a reflexão em torno do meio televisivo e sua peculiar relação com a arte contemporânea, com uma posterior experimentação prática utilizando as técnicas próprias da televisão, por meio da criação do espaço Zero Tv, onde se pretendeu desenvolver novas estratégias com o meio televisivo a partir de sua relação com a arte. As produções desse espaço foram retransmitidas pela MACBAZEROTV, e a Tv Web MACBA ofereceu uma seleção dos trabalhos realizados (MACBA, 2010f).

\section{Conferências, palestras, seminários e mesas redondas}

Foram realizadas conferências, palestras, seminários e mesas redondas com teóricos a respeito dos temas suscitados pelas exposições, ou acerca da obra dos artistas, dentre as quais destacamos: El Toque Spero, conferência ministrada em julho de 2008 a respeito da obra de Nancy Spero, por Jon Bird, professor de Arte e Teoría Crítica na Universidad de Middlesex (MACBA, 2008h); ¿Qué es lo que hace que la modernidade sea tan. Diferente, tan atractiva 
para los artistas visuales de hoy?, mesa redonda realizada em setembro de 2009, que teve como ponto de partida a exposição Modernologías. Artistas contemporáneos investigan la modernidad y el modernismo (MACBA, 2009g); conversa entre John Baldessari e Bartomeu Marí, em fevereiro de 2010, a propósito da inauguração da retrospectiva John Baldessari. Pura belleza (MACBA, 2010g); ¿Pero dónde está la costa? Rodney Graham y el Arte en Vancouver, conferência de Grant Arnold, curador de arte da British Columbia na Vancouver Art Gallery, e de Lynne Cooke, em fevereiro de 2010, a propósito da exposição Rodney Graham. A través del bosque (MACBA, 2010h); conferências e projeções a respeito da exposição ¿Estáis listos para la televisión?, de novembro de 2010 a março de 2011, com a participação de artistas visuais, cineastas e pesquisadores, com o objetivo de refletir sobre a programação cultural na Espanha, revisando experiências culturais pioneiras na televisão (MACBA, 2010i); conversa com Anjalika Sagar e Kodwo Eshun, fundadores do coletivo The Otolith Group que comentaram, em fevereiro de 2011, as obras incluídas na mostra do MACBA (MACBA, 2011f); conferência de Abigail Solomon-Godeau, professora do departamento de História da Arte e Arquitetura da Universidade da Califórnia em Santa Bárbara, que tratou do contexto artístico dos anos setenta nos Estados Unidos e sua relação com o trabalho de Àngels Ribé, em setembro de 2011 (MACBA, 2011g); conversa aberta com Antoni Muntadas, a teórica Anne Bénichou e Bartomeu Marí, por ocasião da exibição da obra Between the Frames: The Forum (Barcelona), 1983-1993 (2011) de Antoni Muntadas e sua incorporação à coleção do Museu, em janeiro de 2012 (MACBA, 2012k); conversa com Rita Mcbride e Bartomeu Marí, curador da exposição monográfica Oferta pública / Public Tender, sobre o trabalho da artista, em maio de 2012 (MACBA, 20121); mesa redonda com os curadores Teresa Granada e Daniel Giralt-Miracle, realizada em junho de 2012, a respeito da pesquisa por trás da exposição ICSID, com a participação do professor de estética da Universidade de La Laguna, José Díaz-Cuyás (MACBA, 2012m); conversa realizada em outubro de 2012, com Nasrin Tabatabai e Babak Afrassiabi, que trabalham em colaboração sob o nome Pages, acerca da exposição Filtraciones (MACBA, 2012n); seminário organizado, em maio de 2013, para apresentação da Coleção Philippe Méaille de trabalhos do Art \& Language (MACBA, 2013f); seminário Palestina En/Sin el Museo, organizado, em fevereiro de 2015, por Kristine Khouri e Rasha Salti no contexto da exposição Pasado inquieto. Narrativas y fantasmas de la Exposición internacional de arte en solidaridad con Palestina, 1978, e que contou com a participação de teóricos e artistas como Fadi Bardawil, Catherine David, Alfredo Jaar, Kristine Khouri, Rasha Salti y Elias Sanba (MACBA, 2015c). 
Em 2010, teve início o projeto ¿Por qué y cómo hago lo que hago? Los artistas hablan, que pretendeu colocar em relação direta os artistas e o público, tornando mais transparente e compreensível o processo de criação artística. Desse modo, foram produzidos materiais audiovisuais documentando o processo de produção de exposições, como no caso da mostra de Armando Andrade Tudela na Capella MACBA (2010), posteriormente disponibilizado no site do Museu, bem como organizadas conversas públicas com os artistas, como a que aconteceu entre Soledad Gutierrez, conservadora de exposições temporais o MACBA, com a artista Natascha Sadr Haghighian sobre o projeto De paso, desenvolvido especificamente para a Capella MACBA (MACBA, 2011h).

Verifica-se também o programa Pregunta a los Comisarios, inciado em 2013, por meio do qual o MACBA organizou conversas informais entre os conservadores do Museu ou curadores independentes, e o público, a respeito das exposições realizadas na instituição (MACBA, 2013g).

Por fim, vale destacar as atividades De qué habla...?, uma série de conversas informais promovidas pelos amigos do MACBA entre os curadores das exposições temporárias do MACBA e convidados de outros âmbitos profissionais, a fim de informar e discutir sobre o programa do Museu, tratando de questões como os temas de cada exposição, os interesses dos artistas, quais os seus vínculos com a Coleção do MACBA, que novas leituras oferece cada exposição, em quais linhas de investigação se inscrevem, entre outras possibilidades. Como exemplo, temos a conversa entre Valentín Roma, curador da exposição Osvaldo Lamborghini. Teatro Proletário de Cámara e Xavi Ayén, jornalista e autor de Aquellos años del boom (RBA, 2014) sobre a vida e a obra do escritor argentino (MACBA, 2015d).

\section{Ciclos de Cinema}

Também foram realizados ciclos de cinema complementares às exposições, como o programa de cinema e vídeo Benet Rossell, detrás y delante de la cámera, realizado de outubro a novembro de 2010, como extensão da mostra Paralelo Benet Rossell no MACBA (MACBA, 2010j); o ciclo de cinema intitulado No podemos prometer que hagamos otra cosa que experimentar, que acompanhou a exposição Museo de narrativas paralelas. En el marco de La Internacional, e apresentou filmes que, no espaço cultural da antiga República Socialista Federativa da Iugoslávia, provocaram uma mudança na linguagem cinematográfica 
dominante e propuseram novos paradigmas temáticos, estéticos e de produção durante las décadas de 1960 e 1970 (MACBA, 2011i); o ciclo de cinema realizado a propósito da exposição Escrito en el viento, a fím de explorar a faceta cinematográfica do artista estadunidense Lawrence Weiner, em maio de 2013 (MACBA, 2013h).

\section{Intervenções}

Outras atividades integradas ao programa expositivo consistiram em intervenções de diferentes tipos no espaço do MACBA. Como exemplos, destacam-se as apresentações realizadas entre outubro e novembro de 2009, a propósito da exposição La anarquía del silencio. John Cage y el arte experimental e da visita da Merce Cunningham Dance Company, em que foram executadas obras de John Cage para o piano, violino e percussão, exibição de filmes do arquivo da Companhia e oficinas para estudantes, ministradas pelos membros da Companhia, tendo sido trabalhados movimentos coreográficos e seus diálogos com o espaço (MACBA, 2009h). Vale notar também as propostas realizadas na obra Arena de Rita McBride, no contexto da exposição Oferta pública / Public Tender, em 2012. Como atividade integrada à exposição, foi convidada uma série de artistas para dar novos usos ao espaço da Arena, durante os quatro meses em que a exposição esteve em cartaz, e que giraram principalmente em torno da performance e da participação (MACBA, 2012o).

\section{Educativo}

Quanto ao desenvolvimento de propostas educativas durante a gestão de Bartomeu Marí, pudemos observar a realização de várias atividades com alunos tanto de educação infantil e primária, como secundária e universitária, em que se destaca o projeto Expressart. Museo Portátil. Iniciado em 2007 e continuado durante a gestão de Bartomeu Marí, o projeto consiste em visitas pelas exposições do MACBA, visando a aproximação dos alunos com a arte contemporânea, seguidas de atividades pensadas a partir da disponibilização de um "kit" educativo pelo Museu, uma espécie de museu portátil, sendo que também foram oferecidos cursos a professores acerca da metodologia do projeto. Outras atividades voltadas para os professores, como parte de um projeto permanente de formação de professorado, envolveram atividades de apresentação dos recursos disponibilizados pelo Museu e acerca das temáticas a serem desenvolvidas. A atividade Hibridaciones. Arte y Arquitectura, realizado em novembro 
de 2012, por exemplo, convidou os professores a conhecer as propostas educativas do Museu a partir de uma visita pelos seus espaços na companhia de um restaurador e de um artista, e envolveu atividades de experimentação da arquitetura com o corpo, a criação de espaços a partir de um olhar fotográfico e repensar a ação a partir do posicionamento performático. Destacamos também o projeto Lecturas de una Colección, realizado entre julho de 2012 e maio de 2013, voltada para o segundo grau e nível superior, em que o MACBA disponibilizou material, na forma de um CD-ROM, a ser trabalhado em sala de aula, atividade que foi seguida de uma visita às obras da Coleção em cartaz no período. A ideia era iniciar debates sobre arte e cultura em sala de aula, os quais seriam continuados nas salas de exposição. Entre julho de 2012 e maio de 2013 foi realizado também o curso Arte contemporáneo. Nível cero, voltado para professores de segundo grau e nível superior, com o objetivo de proporcionar noções básicas em torno das práticas contemporâneas, a fim de examinar novas linguagens artísticas, por meio de um olhar aberto e flexível. Vale destacar também a realização, a partir de outubro de 2012, dos Debates de Educação, uma iniciativa do MACBA junto à Fundação Jaume Bofill e à Universitat Oberta de Catalunya, com o objetivo de impulsionar o debate social sobre o futuro da educação. Os debates, que se estenderam também pelos anos de 2013 e 2014, tiveram como temas: Aura y Temporalidad: La Insistencia del Archivo; Eric Debarbieux - "Mejorar el Clima Escolar: Por Qué y Cómo?; Crear Escuelas qu Prepraren para el Futuro; Privatizar es la Solución? Retos y Tensiones de la Financiación de la Educación; Cómo construimos uma comunidade Educativa Implicada? Cómo combatimos la Desafección Escolar?

O MACBA também participou, em abril de 2014, de um programa pedagógico multidisciplinar e participativo, junto à Escola de Arquitetura La Salle, que teve como objetivo analisar os usos do espaço público no Raval, especialmente nas zonas ao redor do Museu. Denominado Análisis Participativo del Espacio Urbano del Barrio del Raval, o programa visou utilizar o vídeo como ferramenta de análise, documentação e comunicação, de modo que os estudantes de arquitetura da Escola recompilariam os testemunhos da interação dos habitantes com os espaços. Os vídeos produzidos seriam expostos em vários pontos do bairro.

Já para o público geral, vale destacar a criação, em 2014, do projeto Habitáció 1418 , concebido conjuntamente entre o MACBA e o CCCB, que ofereceu um novo espaço de atividades para o público entre 14 e 18 anos, um ponto de encontro ativo abertos aos sábados, no andar térreo do CEDOC, com uma programação contínua de atividades em que se podia 
usar livremente os recursos dispostos pelas duas instituições, e cujo objetivo foi contemplar os jovens da área metropolitana e desenvolver um vínculo especial com o Raval. Entre algumas atividades do programa, verificou-se: oficinas de rádio, dança e experiência corporal, animação digital e programação.

\section{Grupos de leitura}

Foram organizados pelo MACBA, no período, alguns grupos de leitura, que abordaram temas como: Barcelona: del modelo a la marca, de la marca a la crisis, realizado em outubro de 2012, o qual pretendeu analisar as respostas sociais diante da banalização do território, dos processos de extração de riqueza da produção coletiva, dos diversos planos urbanos e das ações públicas e privadas que buscaram construir uma "marca Barcelona", e que refletiam um novo paradigma social de cooperação e solidariedade (2012p). Outro grupo, organizado em 2013, teve como tema Del Chino al Raval. Existe una Estética de Los Bajos Fondos de Barcelona?, no qual foi abordada a mudança ocorrida no bairro que abriga o MACBA, anteriormente chamado de Bairro Chino (Chinês) e conhecido pela prostituição, e que foi revitalizado por meio da instalação de instituições culturais na área, porém sempre sob a ameaça de um processo de gentrificação e higienização (MACBA, 2013i).

\section{Publicações}

Durante a gestão de Bartomeu Marí, observamos a continuidade de edição de publicações acerca das exposições realizadas no Museu, bem como das atualizações periódicas que apresentam e atualizam aspectos da coleção. Também teve continuidade a publicação de ensaios, dos Quaderns portátils, e a novidade dos Quaderns d'àudio, linha de publicações de textos relacionados à programação da Radio Web MACBA. O projeto conjunto de pesquisa Desacuerdos também continuou a ser desenvolvido, tendo sido publicadas edições, durante a gestão de Marí, nos anos de 2009, 2011, 2012 e 2014. Quanto à revista $A g$, esta teve sua última publicação em 2009. 


\section{A diversificação do uso de espaços da instituição}

Como vimos anteriormente, entre as propostas de Bartomeu Marí no início de sua gestão estava uma maior utilização dos espaços expositivos do Convento Dels Ángels e da Capela para exposições e atividades, bem como o comissionamento de obras pensadas especificamente para esses espaços. Assim, a exposição \#01 Armando Andrade Tudela. ahir, demà, em cartaz entre março e junho de 2010, inaugurou uma linha expositiva baseada na criação de obras para o espaço da Capela, que também recebeu as exposições: \#02 Latifa Echakhch, para a qual a artista marroquina concebeu as instalações Eivissa (2010), Gaya (E102) 5, Vitrail (2010) e Fantasia (2010); \#03 Pep Durán - Una Cadena de Acontecimientos, instalação também criada especificamente para o espaço da Capela, e o projeto De Paso, instalação elaborada pela artista Natascha Sadr Haghighian, em exibição de julho a dezembro de 2011 (MACBA, 2011h). Em 2012, a Capela recebeu a obra em vídeo Ebb\&Flow. A Onda Traz, O Vento Leva, de Gabriel Mascaro, em maio de 2012 (MACBA, 2012r).

Também o CEDOC passou a receber exposições em seu piso térreo, complementares ou não a exposições realizadas no prédio principal, tais como El mal de escritura, em cartaz entre novembro de 2009 e abril de 2010, que colocou à disposição dos visitantes cerca de 150 livros, panfletos, ensaios e outros documentos, elaborados por artistas decididos a encontrar novas linguagens e espaços de reflexão para a arte contemporânea; a mostra de arquivo do projeto Twin Tastes \& Tongues, de Antoni Miralda, que tratou das relações entre Barcelona e Shangai, e culminou na elaboração de um projeto para o Pavilhão de Barcelona na Bienal de Shangai; a exposição Espacio de Leitura, pensada para coincidir com a exposição monográfica de Cildo Meireles, em 2009, e que reuniu, além de uma bibliografia sobre a obra do artista, exemplares da Revista Malasartes, por ele fundada, livros de grande relevância quanto ao movimento da poesia concreta brasileira, uma seleção de catálogos de mostras individuais e coletivas, numerosas publicações relacionadas às bienais de arte do Rio de Janeiro e São Paulo, além de revistas, livros especiais, cartazes e outros materiais efêmeros que ilustraram a cena artística brasileira ao longo das últimas décadas (MACBA, 2009i). Também foi realizada, em fevereiro de 2014, uma mesa redonda no espaço, que apresentou o livro Human Rights/Copy Rights. Visual Archives in the Age of Declassification, resultado de um projeto realizado na Universidade do Chile, que teve como objeto os aparatos de mediação visual da memória no momento da desclassificação dos arquivos políticos 
vinculados aos períodos pós-ditadura latinoamericanas (MACBA, 2014c). Houve também a inauguração, em 2014, do Gran Vidrio, uma espécie de vitrine em que passaram a ser apresentados projetos a serem vistos também pelo lado de fora do Museu, e a qualquer momento.

\section{Programas de Colaboração}

Ao longo da gestão de Marí, o MACBA estabeleceu colaborações com instituições de arte, cultura e educação tanto da Espanha como internacionais. Entre eles, destacam-se:

O projeto Creadores En Residencia en los institutos de Barcelona, que surge, a partir do ciclo 2011-2012, da colaboração do Departamento de Programas Educativos do MACBA com o projeto Creadores En Residencia en los institutos de Barcelona, um programa do Institut de Cultura e do Consorci d'Educació de Barcelona, idealizado em colaboração com a Associação A Bao A Qu. O projeto tem como objetivo aproximar a arte à educação, vínculo construído a partir do diálogo constante entre estudantes, professores e artistas. Ainda, a singularidade da proposta permite aos participantes acompanhar de forma ativa a idealização e realização de uma obra, seguindo de perto as metodologias de trabalho dos criadores residentes. Desde os projetos próprios da criação contemporânea, o projeto estimula tanto a experimentação artística como a inovação educativa, além de gerar novos modelos de aprendizagem em contextos de participação coletiva. A colaboração com o MACBA fornece ferramentas de aproximação com o patrimônio artístico e estabelece vínculos entre o fundo da coleção permanente e a experiência em aula a partir de visitas específicas idealizadas conjuntamente poelos criadores e o Departamento de Educação do Museu (MACBA, s.d).

Podemos citar também o projeto de investigação MeLa - Museums in an Age of Migrations. Reinterpreting Europe's Cultural Heritage in the 21st Century, ativo entre $2011 \mathrm{e}$ 2015, que se propôs a analisar o papel desempenhado pela instituição museística na construção e na divulgação do patrimônio cultural europeu, e centrar-se especialmente em alguns âmbitos concretos, como as bibliotecas de museus, além de identificar os novos caminhos suscitados no contexto atual, caracterizado pela mobilidade e pelo câmbio. A participação do MACBA no projeto foi canalizada através do CEDOC, baseada na noção de exposição como instrumento discursivo que contribua à reflexão teórica e à análise de casos de estudo relevantes na historia das exposições; a elaboração, a partir da própia experiência na gestão do arquivo histórico do MACBA, de uma série de pautas de arquivo e documentação, e 
a revisão dos formatos clássicos de apresentação, em colaboração com diversos programas acadêmicos de pós-graduação en arquitetura, design de interiores, etc (MACBA, s.d).

Destaca-se também Magnet. Alianzas para el éxito educativo, projeto com o qual o MACBA colabora desde o ciclo 2012-2013. Trata-se de um programa que põe em contato instituições científicas e culturais de referência e centros educativos. Foi impulsionado pelo Departament d'Ensenyament de la Generalitat e a Fundação Jaume Bofill, inspirado nas escolas magne americanas, que foram adaptadas ao contexto catalão. O objetivo é oferecer durante quatro anos um acompanhamento direto ao projeto pedagógico de cada centro educativo, de maneira que o conhecimento específico da instituição de referência (no caso do MACBA, a arte contemporânea) passe a permear o dia a dia educativo e incida nos processos de aprendizagem (MACBA, s.d).

Outro projeto começou a partir da criação, em 2013, da rede europeia de museus L'Internationale, que o MACBA integra junto à Moderna Galerija (Ljubljana), o Museu Nacional Centro de Arte Reina Sofía (Madrid), o Museum van Hedendaagse Kunst Antwerpen (Amberes), o centro de arte SALT (Istambul e Ankara) e o Van Abbemuseum (Eindhoven), a qual tem o objetivo de estabelecer uma colaboração de logo prazo entre as instituições participantes e, diferentemente de outras experiências similares, potencializar um novo internacionalismo artístico, não hierárquico e descentralizado, fundamentado no valor da diferença e o intercâmbio horizontal, e de modo a criar redes de trabalho, favorecer pesquisas transversais e compartilhar metodologias (MACBA, s.d).

Por fim, nota-se o projeto Apadrina tu equipamiento, do qual o MACBA participa desde 2014, e que incentiva a colaboração entre os grandes equipamentos culturais e os centros educativos do Raval, com o objetivo de desenvolver projetos de aula inovadores que se adaptem às distintas realidades de cada centro (MACBA, s.d).

\section{O MACBA se "reseta"}

Em 2014, Bartomeu Marí anuncia um "reset” nas atividades e propostas do MACBA, o que, no entanto, afirma, não significaria deixar de lado os 26 anos de história do Museu. Tratava-se, melhor dizendo, de uma busca por novos métodos de trabalho, com a intenção de se posicionar internacionalmente, manter a excelência do Museu e captar novos públicos (MONTAÑES, 2014). A reelaboração das linhas de trabalho do MACBA estava amparada também nas figuras de Valentín Roma e Paul B. Preciado, à época curadores independentes 
historicamente vinculados com a instituição, sendo que Preciado era diretora do PEI, desde 2012, figuras que, em 2015, assumem os cargos Curador Chefe e Diretor de Programas Públicos, respectivamente. As novas linhas estabelecidas para ditar a atuação e a investigação crítica em torno das quais passariam a se estruturar os projetos expositivos e os programas públicos do Museu foram organizadas sob os títulos: Histórias heterodoxas; Descolonizar o museu; Máquina de escrever; Corpo político, Arquitetura como prática cultural e Tecnologias da consciência, que, de acordo com Marí, respondiam ao interesse comum de compreender a arte contemporânea como parte dos processos de emancipação política, estética, somática e social (MONTAÑES, 2014).

A linha de Histórias Heterodoxas diz respeito a cartografar e dar visibilidade a uma pluralidade de narrativas dissidentes frente aos relatos historiográficos dominantes, transformando o museu em um foro de debate onde expor o conflito e a contradição de uma multiplicidade de narrativas normativas (MACBA, 2014d). Descolonizar o museu explora a produção de discursos críticos pós-coloniais e de descolonização, assim como a proliferação de um conjunto de práticas que põem em questão as narrativas e as representações coloniais eurocêntricas que fundaram o museu moderno. Neste marco crítico, o Norte da África e o Oriente Médio se convertem em áreas de atenção e colaboração (MACBA, 2014d). A linha Máquina de escrever diz respeito ao entendimento do museu como um lugar em que as distintas formas de narrar o mundo se encontram, codificam-se, decodificam-se e se traduzem por meio da prática artística, oferecendo novos recursos para pensar os vínculos entre arte e escritura (MACBA, 2014d). A linha de trabalho Corpo Político previa a investigação das relações entre arte, produção biopolítica e emancipação no contexto do capitalismo global, além de analisar as transferências entre saberes subalternos e práticas performativas, linguagens minoritárias e políticas pós-identitárias, entre corpo e tecnologia, arte ao vivo e digitalização do corpo, postulando-se que arte e museu podem funcionar como laboratórios e microesferas públicas onde se inventam e sem põem à prova modelos dissidentes de subjetividade política (MACBA, 2014d). Com Arquitetura como prática cultural, pretendeuse estudar, para além dos historicismos da arquitetura e do design, as relações complexas entre arquitetura, arte, urbanismo crítico, produção da cidade contemporânea e teoria da cultura. Nesse contexto, as relações entre capitalismo e transformação urbana, assim como as práticas sociais e críticas de reinvenção da "praça pública" e da "habitação social" assumiriam especial importância (MACBA, 2014d). Por fim, sob o título Teconologias da Consciência, cartografar-se-iam as tecnologias de produção de consciência e suas relações com as práticas 
de arte, desde a modificação da percepção até a invenção de novas formas de experiência e relacionalidade marcadas pela expansão das próteses audiovisuais e bioquímicas na modernidade (MACBA, 2014d).

A iniciativa teve o intuito de reativar a instituição, que, nos últimos anos, vinha sofrendo certa letargia (SESÉ, 2014). De acordo com Preciado, o futuro do MACBA passava por implicar-se com a produção e estimular as criações dos artistas. Ainda, para ele, repensar um museu do século XXI, um lugar para a utopia, passava por questionar acerca do que poderia ser oferecido naquele momento, em Barcelona e no Raval. No mesmo sentido, Roma destacou a necessidade de o MACBA se aproximar de seu contexto, da cidade e dos artistas (SESÉ, 2014). A intenção de Marí, junto à Preciado e Roma, era a de repensar o Museu, reprogramando suas atividades até o final de 2016, com formatos mais flexíveis e híbridos (FRISACH, 2014). Preciado destacou também que se tratava de mudar as linguagens com que se trabalhava a arte, de modo que não se podia continuar utilizando linguagens dos anos cinquenta, já que o contexto das práticas contemporâneas havia mudado. Preciado sugeria, então, uma hibridação entre as exposições e os programas públicos (FRISACH, 2014). Também intentava-se realizar exposições coletivas enfatizando a produção local, mas sem deixar de lado artistas de fora (FRISACH, 2014).

O ponto de partida dessa nova etapa foi abril de 2014, quando coincidiram as exposições de videoarte de Eugeni Bonet, a projeção do filme The host and the cloud, de Pierre Huyghe e a exposição coletiva La realitat invocable (FRISACH, 2014), os quais foram organizadas sob a linha de pesquisa de Arqueologia, presente e futuro da imagem em movimento e, de acordo com as novas linhas de atuação e investigação crítica estabelecidas, encontravam-se vinculadas às linhas Histórias heterodoxas e Máquina de escrever. O projeto coletivo La realidad invocable buscou explorar possíveis perspectivas da realidade a partir de práticas artísticas, através de uma seleção de obras de artistas percencentes a diferentes contextos e gerações, além de ter pretendido interpelar seu contexto artístico mais imediato, sendo também por ele interpelado, e assumindo o compromisso de produzir trabalhos de artistas que expunham pela primeira vez no MACBA (MACBA, 2014d). O projeto De trípticos, comissariado por Frederic Montornés, buscava estabelecer conexões entre obras presentes na Coleção MACBA e produções específicas de artistas da cena emergente. A proposta estava vinculada às linhas de pesquisa Corpo Político, Histórias heterodoxas e Máquina de escrever (MACBA, 2014d). 
Já as exposições La pasión según Carol Rama, com curadoria de Paul. B Preciado e Teresa Granadas; Osvaldo Lamborghini, com curadoria de Valentín Roma; Joan Brossa, curada por Hans-Ulrich Obrist e Pedro G. Romero; Ajoblanco. Arte, política y ciudad, curada por Valentín Roma, e Dancing Phantoms, com curadoria de Rasha Salti e Kristine Geneviève Khouri, encontravam-se dentro do conceito Hacia un saber de la heterodoxia (em direção a um saber da heterodoxia). Ainda, La pasión según Carol Rama estava vinculada às linhas de pesquisa Corpo político e Histórias heterodoxas; Osvaldo Lamborghini às linhas Máquina de escrever, Histórias heterodoxas e Corpo político; Joan Brossa às linhas Histórias heterodoxas e Máquina de escrever; Ajoblanco. Arte, política y ciudad às linhas Tecnologias da consciência, Histórias heterodoxas, Corpo politico e Máquina de escrever; Dancing Phantoms às linhas Descolonizar o museu e Máquina de escrever. O projeto para a exposição Ajoblanco. Arte, política y ciudad abordou a trajetória da revista Ajoblanco, que percorre um amplo da vida pública espanhola ao longo de duas etapas diferentes (outubro de 1974 - maio de 1980 / outubro de 1987 - dezembro de 1999). Participaram da revista a maior parte dos intelectuais de ambos os períodos, assim como coletivos e grupos de trabalho que contribuíram para fazer da revista um verdadeiro panóptico das tensões históricas e estéticas na Espanha ao longo de mais de vinte anos (MACBA, 2014d). O projeto para Dancing Phantoms, realizado por Rasha Salti e Kristine Geneviève Khouri, partia da pesquisa acerca da exposição Artista en apoyo a Palestina, organizada em Beirute em 1978 (MACBA, 2014d).

Outro bloco de exposições girava em torno do questionamento da arquitetura quanto a sua escala e historicismo, em que ela reaparece reconvertida em prática cultural e em linguagem discordante. Nesse bloco, figuravam exposições como: Oskar Hansen. Forma Atwerta / Forma abierta, que disse respeito ao interesse do MACBA em entender o papel da arquitetura na expressão de modernidades externas à ortodoxia, e centrou-se sobre a evolução da teoria de forma aberta do arquiteto polonês Oskar Hansen (1922-2005), concebida como ferramenta para o design de projetos arquitetônicos e cuja aplicação na pedagogia da arte, edição de filmes, jogos visuais e prática preformativa deu lugar a um amplo conjunto de experimentos que situam a interação com o outro, o intercambio e a socialização do objeto artístico no centro de atenção do criador. Tal proposta esteve vinculada às linhas de pesquisa Arquitetura como prática cultural e Histórias heterodoxas. Destaca-se também o projeto Nonumento, organizado por Bartomeu Marí e o arquiteto Josep Bohigas, que buscou refletir sobre a transferências simbólicas entre monumento, espaço público e efeméride a partir de 
uma série de trabalhos especificamente desenvolvidos para a exposição, em que distintos artistas que operam no campo da arquitetura social e do urbanismo crítico não apenas pretenderam apresentar suas linhas de trabalho, mas, sobretudo, suas propostas para o futuro. Tal projeto esteve vinculado às linhas de pesquisa Arquitetura como práctica cultural e Descolonizar o museu (MACBA, 2014d).

No que tange à apresentação da Coleção, foi criado, dentro dessas novas propostas, o projeto Aqui comienza nuestra historia (Aqui começa nossa história), que planejou realizar um "tríptico expositivo" entre 2014 e 2016, que revolveria em torno do período compreendido entre o final dos anos setenta e o início dos noventa. A primeira exposição prevista foi Capítulo 1 - Coleção MACBA, prevista para maio de 2014, vinculada às linhas Histórias heterodoxas, Descolonizar o museu, Corpo político, Tecnologias da consciência, Arquitetura como prática cultural e Máquina de escrever (MACBA, 2014a). As exposições seguintes foram denominadas no projeto inicial como Capítulo 2 - Coleção $M A C B A$, prevista para maio de 2015, e Capítulo 3 - Coleção $M A C B A$, prevista para fevereiro de 2016. Ambas estariam vinculadas às linhas de pesquisa Histórias heterodoxas; Descolonizar o museu; Corpo político; Tecnologias da consciência; Arquitetura como prática cultural e Máquina de escrever (MACBA, 2014d). A primeira exposição realizada acabou por ser intitulada La Herencia Inmaterial - Ensayando desde la Colección, em cartaz de maio de 2014 a maio de 2015.

Havia também, no programa, um bloco de exposições que abordavam as complexidades do território, vistas a partir da arte: desde a geografia política vista através do documento fotográfico até a paisagem interpelada pela escultura (MACBA, 2014d), e reunia as exposições: Xavier Ribas. Nitrato, prevista para junho de 2014 e vinculada às linhas de pesquisa Descolonizar o museu, Histórias heterodoxas e Máquina de escrever, projeto que mostra a geografia política do deserto do Atacama e a história da extração desse mineral a partir de uma série de polípticos fotográficos, textos e vídeos por meio dos quais o artista investiga o valor da fotografia como objeto reflexivo, e não tanto como suporte documental. A exposição da obra do artista catalão Sergi Aguilar, prevista para agosto de 2015, e vinculada às linhas de Arquitetura como prática cultural e Histórias heterodoxas; Usos inapropiados de lo sagrado, exposição coletiva prevista para julho de 2015, vinculada às linhas de pesquisa Descolonizar o museu, Corpo político, Histórias heterodoxas e Máquina de escrever, com obras de artistas 
locais, nacionais e internacionais, que buscaram indagar sobre as novas considições e usos do sagrado, as transferências entre arte, economia e política (MACBA, 2014d).

Outra seção do programa previa mostras que buscavam a aproximação entre as práticas linguísticas e fotográficas coletivas, contando com exposições como: Art \& Language incompleto. Colección Philippe Méaille, exposição ligada às linhas Histórias heterodoxas e Máquina de escrever, prevista para setembro de 2014, que buscava mostrar essa coleção que constitui uma destacada representação de um das praticas mais complexas e beligerantes da segunda metade do século XX, referente a obra de um grupo que, desde meados dos anos sessenta, fundamentou-se na assimilação de práticas artísticas críticas e dissidentes de acordo com uma perspectiva de base linguística, conversacional e discursiva, que continua até os dias de hoje (MACBA, 2014d); Arab Image Foundation, prevista para março de 2015, vinculada às linhas de investigação Descolonizar o museu, Histórias heterodoxas e Máquina de escrever (MACBA, 2014d).

Ainda no âmbito das novas propostas, os programas públicos foram pensados como "parlamentos cognitivos e corporais", como um lugar em que as distintas linhas de investigação do Museu se convertem em espaços de debate público e de intermediação entre as correntes discursivas do Museu e a cidade: parlamentos cognitivos e corporais nos quais se possa reimaginar o âmbito social. Assim, foram propostas a construção de uma série de plataformas de pesquisa, criação, ação, relação e intercâmbio na qual os distintos agentes pudessem redefinir a esfera pública a partir de variáveis críticas e minoritárias (MACBA, 2014d). Foram planejadas, para 2014 e 2015, atividades como o evento La Noche, que, em maio de 2014, pretendeu inaugurar um novo formato de atividade pública, buscando fundir os recursos característicos do seminário com a potência criativa da exposição. Tratava-se, ao mesmo tempo, de uma instalação crítico-performativa e de uma exposição efêmera (MACBA, 2014e). Assim, de acordo com a proposta, se o seminário trabalhava com a palavra crítica, $L a$ Noche intentou explorar as articulações entre a palavra poética, a prática performativa, $\mathrm{o}$ discurso crítico e a produção audiovisual. Se a exposição posicionava uma obra no espaço destacando sua dimensão visual, La Noche acentuaria o caráter temporal, performativo e relacional da prática artística contemporânea (MACBA, 2014e). A atividade foi criada como um encontro da festa e da assembleia, do popular e da crítica, do teatro e da academia, da praça pública e do museu (MACBA, 2014e). Outra atividade pública prevista foi o Ciclo de Conferências El Mundo al revés. Gramáticas de lo Imposible y Práticas de Transformación de lo Real, proposta para ser realizado em duas partes, contando com agentes relevantes da 
cena internacional de arte contemporânea e do pensamento crítico, que abordariam a prática e a intervenção política e cultural do presente. Entre os convidados para participar estariam Luc Boltanski, Fred Moten, Frédéric Lordon, Bruno Latour, Catherine Malabou, Donna Haraway, Patricia Falguières, entre outros (MACBA, 2014d).

Também foi enfatizada a continuidade de diversificação do uso dos espaços expositivos do MACBA, foram concebidas exposições de modo a se explorar a singularidade da Capela MACBA, estabelecendo-se um diálogo específico entre o espaço arquitetônico o artista e o curador. Nesse contexto, foram propostas as exposições Singalit Landau, José Antonio Hernandez-Díez e Carlos Bunga (MACBA, 2014d).

Quanto aos seminários de pesquisa, foi proposto Estética y emancipación, buscando aprofundar a linha de investigação Descolonizar o museu, por meio de uma série de seminários, oficinas e plataformas de debate, de modo a reunir diferentes atividades que convocassem artistas, agentes críticos e ativistas e gerassem um marco crítico no qual pensar as lógicas de emancipação, assim como a implicação das práticas artísticas contemporâneas nos processos de descolonização. Foram propostos cinco deslocamentos críticos: Marx na África; Thomas Bernhard em San Salvador; Joseph Beuys em Kabul; Simone de Beauvoir en Medellín; Freud em Orán (MACBA, 2014d).

Também foram elaborados novos projetos editoriais, para além dos catálogos expositivos, consistindo nas coleções: Diccionario de Nuevas Gramáticas de Arte Contemporáneo, que propunha uma cartografia de novas linguagens para compreender a prática artística; Cambiar de idea, uma série de ensaios que buscariam tratar o deslocamento da crítica da arte e do pensamento contemporâneo articulados com as seis linhas de investigação do MACBA; Archivos e Interpelaciones, que reuniriam as publicações vinculadas a projetos expositivos; Cadernos Esta es La Noche, dispositivo discursivo e audiovisual que acompanha esse novo formato de atividade pública, capaz de funcionar como um protocolo ou partitura que permita replicar o evento em outro contexto (MACBA, 2014d).

Destaca-se a realização de cursos e encontros como El Descontento y la Promesa. Colonialidad. Modernidad y Epistemologías Descoloniales, ministrado por Walter Mignolo em junho de 2014, que partiu de uma releitura crítica da história da modernidade, de que a narrativa civilizatória do Iluminismo não foi o Humanismo, mas sim a colonização. Assim, num contexto de projetos de descolonização, que apostam na desconstrução da razão racial e patriarcal e sua lógica diferencial de progresso, o curso procurou levantar algumas questões: que lugar ocupam as instituições culturais na narrativa da modernidade colonial? O museu 
pode ser um lugar de descolonização do conhecimento e da sensibilidade ou segue sendo, na atualidade, um espaço de regulação e controle da produção de significado e de subjetividade? (MACBA, 2014f); o encontro Descolonizar el Museo, coordenado por Paul B. Preciado, em novembro de 2014, para o qual foram convidados uma série de críticos, artistas, curadores e ativistas com o objetivo de explorar as linguagens e práticas de descolonização que colocam em questão as narrativas e representações imperiais e eurocêntricas que fundaram o museu do século XIX e XX. Foram explorados temas como Descolonizar la Historia, El Conocimiento, El Deseo, e Práticas, Activismos y Redes Descoloniales. Paralelamente ao encontro, foram realizadas atividades como B.D. Women: de la herida colonial a la disidencia sexual, projeto de investigação-ação que buscou a ampliação e ativação de um arquivo de linguagens poético-políticas produzidas entre os anos oitenta e noventa pelas "diásporas críticas": uma multitude de vozes que contesta os novos regimes de racialização e sexualização intensificados na era neoliberal, além da atividade Barcelona (des)colonial. Posesiones de Ultramar y Cambio Urbano (1835-1898), realizado junto ao projeto Ruta de Autor, que consistiu num itinerário que pretendeu investigar sobre o investimento do capital gerado a partir da exploração das colônias na América na transformação da cidade de Barcelona (MACBA, 2014g).

Entre junho de 2015 e maio de 2016, foi realizada a exposição Deseos y necessidades, que buscou mostrar as novas incorporações à Coleção MACBA, realizadas ao longo dos três anos anteriores. A exposição apresentou 86 obras, entre novas aquisições e outras que já faziam parte da Coleção. A exposição se articulou em torno de oito capítulos centrados em grupos de obras que abarcam um leque cronológico de mais de seis décadas. Destaca-se como a Coleção incorporou trabalhos de características muito diversas: desde a atenção à pintura abstrata dos anos cinquenta e sessenta, em que se situa a o trabalho de Esteban Vicente, passando pela abstração racional e não expressionista de inspiração matemática ou minimalista, com Esther Ferrer ou Néstor Sanmiguel, até obras significativas de artistas centrais no discurso construído pelo MACBA nas últimas décadas, como John Baldessari, Richard Hamilton, Pablo Palazuelo, Joan Brossa, Marcel Boodthaers, Öyvind Fahlström, Dieter Roth e Antoni Muntadas (MACBA, 2015). Deve-se notar também como se incluem na Coleção novas vozes da arte atual, como Patricia Dauder, Francesc Ruiz e Mireia Sallarès, bem como artistas consolidados como Gego, Antoni Llena, Dora García o Francesc Abad. Ainda, as propostas de Younès Rahmoun, Sigalit Landau, Walid Raad e Wael Shawky centram-se sobre a criatividade no norte da África e Oriente Médio. Outras obras, como as de 
Ali Cherri e Adrian Melis, nos convidam a questionar a vigência dos meios de comunicação como poder autêntico que escreve a história. Os trabalhos de Richard Hamilton e João Maria Gusmão + Pedro Paiva refletem a fascinação que a inovação científica exerceu sobre a arte moderna. De outro lado, as mudanças sociais e culturais que a economia global imprime em nossa sociedade se evidencia nas aportações de Octavi Comeron e Marc Pataut. O papel da fotografia também esteve presente com trabalhos de Allan Sekula e Jorge Ribalta (MACBA, 2015).

Diante dessas propostas, pode-se constatar a intenção de atualização das diretrizes estabelecidas na gestão anterior, ao se pensar as necessidades de um museu do século XXI, ainda no sentido da reescritura das narrativas canônicas e as representações eurocêntricas presentes na História da Arte, porém levando-se em consideração novas linguagens na abordagem da arte contemporânea, bem como as novas formas de percepção e experiência trazidas pelas tecnologias, além de destacar o trabalho de novos artistas que nunca haviam exposto no MACBA. Desse modo, observa-se, no planejamento de Marí, junto à Roma e Preciado, de continuar e atualizar as experimentações institucionais no MACBA, de acordo com as necessidades de uma nova época.

Infelizmente, o desenvolvimento dessas novas propostas acabou por ser interrompido pela metade, devido à instalaçãoe, março de 2015, de uma crise política no interior do Museu, analisada a seguir. Desse modo, projetos como a exposição Ajoblanco. Arte, política y ciudad e Usos inapropriados de lo sagrado, o ciclo de conferências El Mundo al revés. Gramáticas de lo Imposible y Práticas de Transformación de lo Real, o seminário Estética y emancipación, os novos projetos editoriais, entre outras propostas previstas para o período 2014-2016, acabaram por não ser realizados.

\subsubsection{A Besta e o Soberano}

No dia 18 de março de 2015, estava prevista a inauguração da exposição A Besta e o Soberano no MACBA, uma coprodução entre o Museu e a Württembergischer Kunstverein (WKV) de Stuttgart, sob curadoria de Valentín Roma, Paul B. Preciado, Hans D. Christ e Iris Dressler. Os dois primeiros atuavam, desde janeiro daquele ano, respectivamente como Curador Chefe e Diretor de Programas Públicos, sendo os últimos codiretores da WKV. Tomando como referência para o título um seminário ministrado por Jacques Derrida em 2002, a exposição buscava explorar como as práticas artísticas questionam a definição 
ocidental e metafísica de soberania política, ou seja, o modo como essas propõem maneiras de entender a liberdade e a emancipação que excedem o marco da autonomia individual, assim como a forma moderna do Estado-nação (MACBA, 2015). Entretanto, um dia antes da abertura, foi anunciado seu cancelamento, o que o diretor Bartomeu Marí atribuiu a um desacordo entre a direção e os curadores da mostra, ao passo que a página contendo informações acerca da exposição, que já estava online há certo tempo, saiu do ar (ESFERA PÚBLICA, 2015). Logo se soube que tal desavença dizia respeito à negativa dos curadores em retirar, a pedido do diretor, uma escultura da artista austríaca Ines Doujak, que havia sido exposta em 2014 na Bienal de São Paulo, sob o título Not Dressed for Conquering. O trabalho representava uma cena sexual em que figuravam o Rei Juan Carlos da Espanha, a líder feminista boliviana Domitila Barrios de Chúngara e um pastor alemão. A artista explicou, à época, que tal escultura, fruto de um projeto de investigação sobre as complexas relações entre Europa e América Latina, era uma representação visceral de um longo processo de exploração (ARTISCHOCK, 2015).

O diretor do MACBA então declarou que a mensagem da escultura ia contra as linhas de trabalho da instituição, e que inclusive não havia tido conhecimento da obra de Doujak. Por outro lado, de acordo com os curadores da exposição, Marí tinha sim noção do conteúdo que seria exibido. Eles ainda assinalaram que a decisão do diretor do MACBA colocava em perigo não apenas aquela exposição, mas também revelava o funcionamento não democrático de uma instituição cultural pública (ARTISCHOCK, 2015). Ainda, os artistas participantes da exposição declararam que seu cancelamento significou reprimir um projeto concebido para fomentar um debate público, produtivo e progressista em um contexto de importantes mudanças na hegemonia política do país. Para eles, uma vez que os debates públicos são a essência da democracia, bem como a função de um museu é contribuir com tais debates, a instituição estaria, por meio de sua decisão, traindo não apenas sua missão, mas também sua própria história, caracterizada por uma importante contribuição à reinvenção radical do museu como um espaço público (ARTISCHOCK, 2015).

Em outra declaração, Paul B. Preciado (2015) afirma que a decisão de Bartomeu Marí em cancelar a exposição reproduziu precisamente as lógicas do poder soberano e o funcionamento oligárquico das instituições públicas que a própria exposição pretendia colocar em dúvida por meio dos trabalhos dos artistas. Para Preciado (2015), tal arbitrária decisão teria conseguido, ao menos, escancarar a crise quanto ao espaço de debate e representação democrática do Museu. 
Também em um texto publicado à época, Jorge Ribalta (2015) assinala que a decisão tomada por Marí foi entendida por muitos como fruto de uma pressão exercida por membros da Fundação MACBA, uma vez que figuravam como Presidente e Presidente Honorária, respectivamente, Leopoldo Rodés, amigo pessoal do antigo rei e a esposa de Juan Carlos I, a antiga Rainha Sofía. Ribalta (2015) ainda nota como Marí declarou não ter recebido qualquer ordem da Fundação para cancelar a exposição, o que não minaria o caráter repressivo da decisão, afinal, indagou Ribalta (2015), qual seria a diferença entre censura e autocensura?

Ainda em meio à polêmica, a imprensa local acompanhou a crise, e a opinião pública expressou profundas preocupações com relação à censura promovida por Marí. Organizações de artistas e críticos locais, como a Asociación de Profesionales de la Gestión Cultural de Catalunya, bem como internacionais, como a rede Conceptualismos del Sur, composta por vários artistas e pesquisadores ligados ao PEI, repudiaram e consideraram o cancelamento da exposição um ataque à liberdade de expressão, enquanto os trabalhadores do MACBA firmaram um comunicado no qual manifestavam seu rechaço pessoal e profissional às atitudes do diretor (EL DIARIO, 2015).

Foram organizados debates públicos sobre a constituição oligárquica e antidemocrática das instituições públicas de arte, e a Fundação MACBA foi apontada como o poder dominante oculto do Museu, de modo que, para Ribalta (2015), que uma fundação privada pudesse controlar o Museu estava em completa contradição com a missão democrática de qualquer instituição pública. Ele ainda fez referência à declaração dos funcionários do MACBA, por meio da qual esses expressaram seu desacordo com relação ao sistema dirigente do Museu, tanto no que diz respeito ao Consórcio, como quanto a sua direção artística, uma contribuição inesperada ao debate público, e que apontava para um potencial conflito interno no Museu (RIBALTA, 2015).

Como desfecho da situação, Bartomeu Marí voltou atrás e decidiu reabrir a exposição, a partir do dia 21 de março de 2015, alegando que, se inicialmente ele pensara que a não inclusão da obra de Ines Doujak ou a não abertura da mostra protegeria o MACBA como instituição cultural dedicada ao serviço público, as consequências dessa decisão teriam sido contrárias às desejadas e, diante da publicidade dada à obra e as opiniões emitidas por diferentes setores da sociedade, desde o mundo da arte e da cultura até a política e os meios de comunicação, assim como os profissionais internacionais da arte, ele reconsiderava sua decisão inicial, propondo a reabertura da exposição. Em seguida, no dia 23 de março de 2015, o diretor renuncia a seu cargo no MACBA, sendo que a última decisão de seu mandato foi a 
demissão de Valentín Roma e Paul B. Preciado de seus cargos, devido ao que definiu como uma "quebra de confiança" (ARTE INFORMADO, 2015).

Oito meses depois, o caso ainda tinha repercussões, sendo que três membros da junta executiva do Comitê Internacional de Museus e Coleções de Arte Moderna (Cimam), presidida por Bartomeu Marí desde 2013, renunciaram a seus cargos: Charles Esche, Vasif Kortun e Abdellah Karroum aproveitaram a conferência anual do órgão, realizada em Tóquio, para anunciar sua decisão, fundamentada em uma "perda de confiança" em seu presidente (SESÉ, 2015). Em um comunicado conjunto, os três membros consideram que os museus de arte dedicados a temas contemporâneos devem ser lugares para o livre intercâmbio de ideias, onde o debate seja permitido e incentivado. Lugares chave por onde as novas ideias e possibilidades possam ser instroduzidas na sociedade e, por isso mesmo, frequentemente estão sob ameaça. Nesse sentido, eles concluem que a principal tarefa do Cimam atualmente é defender ao máximo esse espaço para o debate e para estabelecer normas éticas de comportamentos para os artistas, curadores e o público, e explicam que o curso dos acontecimentos no MACBA e na junta diretiva do Cimam os levara a duvidar da capacidade de Marí para defender tais valores de maneira convincente (SESÉ, 2010).

\subsubsection{A recepção da gestão de Bartomeu Marí}

Em 2013, a pesquisadora Cristina Garrido afirmou que, à época, as exposições do MACBA tendiam a adotar uma linha cada vez mais ascéptica, e as atividades públicas haviam se reduzido tanto em número em qualidade, exceptuando-se espaços abertos por alguns membros da equipe de Marí. Ela também destaca como, segundo pesquisa da época, quase $90 \%$ dos visitantes do Museu eram turistas, uma cifra que demonstrava o distanciamento entre o Museu e o tecido social local da cidade, tanto do público geral como especializado (GARRIDO, 2013). Vale lembrar que precisamente diante desse cenário surgiram as novas propostas de reset da instituição, encabeçadas por Valentín Roma e Paul B. Preciado.

Ademais, nota-se que a gestão de Marí ficou bastante marcada por sua polêmica decisão de cancelar a exposição A Besta e o Soberano, que acabou por instaurar uma crise no Museu, e culminou na demissão de Valentín Roma e Paul B. Preciado e a própria renúncia de Marí ao cargo de diretor.

Em meio à crise, Manuel Borja-Villel (2015) aproveitou para realizar uma análise da situação das instituições culturais no século XXI, indagando se de fato seriam livres os museus. O ex-diretor do MACBA assinalou uma "imposição gerencial" sobre as instituições 
culturais, com base na qual tudo seria medido em termos de índice de resultados, os projetos artísticos não seriam avaliados por sua relevância estética ou pedagógica, e nem os processos seriam importantes, mas sim a eficácia da gestão e sua capacidade de gerar recursos (BORJAVILLEL, 2015). Como consequência, Borja-Villel (2015) alude a um encurralamento das instituições públicas em um aparato burocrático complexo, que tende à banalidade, a preservar os procedimentos estabelecidos e a assegurar a ortodoxia legal, e não a impulsionar a inovação, a capacidade de provocar rupturas e imaginar novos mundos. Diante disso, o exdiretor do MACBA levanta alguns questionamentos: corresponderiam os museus aos aspectos mais progressistas da arte contemporânea ou teriam eles se adaptado às pressões de um mercado mais voraz a cada dia? Eles respondem às demandas da sociedade? E, se sim, a quais setores? Aos detentores do poder econômico, àqueles que mantêm o poder político? Ou aos que ainda necessitam ter voz? Diante disso, para ele, em pleno século XXI, o museu ainda se encontrava em uma encruzilhada (BORJA-VILLEL, 2015).

Ao analisar as raízes do problema no MACBA, Ribalta (2015) aponta para disfunções internas no Museu, como o esvaziamento da função do diretor, cujas tarefas, como definir e executar um programa acadêmico e artístico, vinham sendo transferidas aos curadores contratados, o que transformou aquele que deveria ser um papel de liderança por parte do diretor, em algo meramente representativo. Ribalta (2015) atribui a responsabilidade pela crise no MACBA não apenas a Marí, mas também ao Consórcio, por apoiar e manter tal situação durante anos, e de modo que a figura do diretor acabava também por não interferir quanto à autoridade do Consórcio. Ribalta (2015) também culpa Marí por não ter resistido ao corte sistemático de fundos que o Museu passou a sofrer a partir de 2010, como parte de cortes gerais no financiamento público em órgãos espanhóis e instituições públicas, o que representaria, por sua vez, a negligência do Consórcio ante o papel intelectual do Museu (RIBALTA, 2015). O ex-diretor de Programas Públicos atenta também para os perigos de que instituições públicas deixem que interesses privados e oligárquicos determinem $\mathrm{o}$ direcionamento de suas escolhas (RIBALTA, 2015).

Para Xavier Bru de Sala (2015), a primeira e última causa do "fracasso" do MACBA é o que ele chama de "instável cadeira de três pernas", que seriam as figuras da Prefeitura, Generalidade e Fundação que formam o Consórcio MACBA. Assim, para ele, se acaso pensava-se que a solução para a crise instaurada a partir da censura de A Besta e o Soberano era um novo diretor, muito se enganava: o problema, na realidade, era a instável base ideológica e institucional sobre a qual se equilibra o Museu. 
Também em seu posicionamento quanto à crise desencadeada pelo cancelamento da exposição, por meio de um comunicado, os artistas, curadores, professores e pesquisadores da rede Conceptualismos del Sur destacaram um problema que acreditavam atingir o MACBA e muitas outras instituições artístico-culturais dentro e fora da Espanha: o de que a composição do patronato do Museu respondia a uma confluência de interesses político-econômicos aos quais se tentava subordinar os projetos críticos e emancipatórios (REDCSUR, 2015).

\subsubsection{Sobre a gestão de Bartomeu Marí}

Tendo observado tanto as propostas do diretor para o MACBA no início de sua gestão, quanto as atividades realizadas no período, pudemos notar a intenção de Bartomeu Marí em dar continuidade às diretrizes propostas anteriormente por Borja-Villel, bem como de reinventá-las de acordo com as necessidades de um contexto mais atual, junto à Valentín Roma e Paul B. Preciado. Vimos como Marí ratificou a necessidade de o Museu promover visões alternativas à historiografia tradicional, seja por meio de exposições com base em obras da coleção, conforme notamos por meio de exemplos como Moderno y Presente Cambio de Siglo en la Colección $M A C B A$, ou lançando mão de ferramentas como as exposições de tese e monográficas, com o objetivo de questionar perspectivas canônicas na História da Arte, bem como explorar o trabalho de artistas pouco conhecidos nesse âmbito, caso de mostras como Archivo Universal. La condición del documento y la utopía fotográfica moderna e La Pasión Segundo Carol Rama, entre vários outros. Como acréscimos ao que vinha sendo realizado até então, notamos o incentivo à abordagem de períodos mais recentes no estudo da arte, como os oitenta e noventa, até então pouco explorados pelo Museu, como por meio da exposição La Herencia Inmaterial - Ensayando desde la Colección, que abarcou práticas artísticas do início dos anos noventa. Pudemos observar, também, a intenção de se "resetar" o programa do Museu, proposta baseada em seis novas linhas de trabalho, cujas atividades visavam reaproximações entre o MACBA e a comunidade de Barcelona e do Raval, a continuidade da escritura de histórias heterodoxas e com o intuito de descolonizar o Museu, dessa vez por meio de atividades com formatos mais flexíveis e híbridos. É importante ressaltar também a intenção de Marí e seus colaboradores em dinamizar a realização de atividades nos espaços anexos ao prédio principal do MACBA, como o Convento Dels Àngels e a Capela, que, como vimos, passaram a receber exposições site 
specific, pensadas especialmente para esses espaços. Também o piso térreo do CEDOC passou a receber exposições documentais, paralelamente a outras atividades do Museu.

A proposta de reset pensada por Marí, Roma e Preciado, em 2014, foi de grande importância no sentido de uma revisão crítica do que vinha sendo realizado pelo MACBA até o momento, bem como de uma atualização dos objetivos da instituição frente a novas necessidades, condições e práticas artísticas de um contexto mais recente, e da continuação da realização de experimentações institucionais, na busca por novos formatos de atividades, mais flexíveis e híbridos. Se levarmos em consideração as atividades realizadas durante a gestão de Borja-Villel, que aqui tomamos como parâmetro, denominadas experimentos em uma Nova Institucionalidade, percebemos que, de forma geral, as atividades dessa nova gestão não tiveram, no entanto, tanto envolvimento com coletivos e movimentos sociais no sentido de um trabalho coletivo "de fora para dentro", como por meio da elaboração de exposições e atividades de forma conjunta, ou "de dentro para fora", por meio do envolvimento direto do MACBA nos projetos desses coletivos e movimentos. É claro que há que se destacar atividades importantes como Museo oral de la revolución, concebida por Paul B. Preciado a partir do PEI, em 2013, a qual prenunciava a proposta de reset, que envolvia mais atividades colaborativas, híbridas e flexíveis dentro do Museu, como foi o caso de La Noche. No entanto, vale ressaltar como o novo programa acabou por ser suspenso, de modo que não foi possível avaliá-lo por completo. Sendo assim, há que se tratar do episódio que levou ao eventual interrompimento da proposta: a opção de Marí pela censura, ou uma autocensura, e a posterior demissão de Roma e Preciado, antes de sua saída. Diante disso, por um lado, indagase se talvez Marí não tenha tido pulso firme para posicionar-se diante de uma possível insatisfação da Fundação com a obra de Ines Doujak. Por outro lado, revela-se, mais uma vez, como, na prática, os diretores teriam autonomia limitada dentro da instituição, diante de eventuais conflitos de interesses com relação aos órgãos integrantes do Consórcio.

\subsection{A gestão de Ferran Barenblit}

Após a renúncia de Bartomeu Marí, inicia-se o processo de escolha de um novo diretor para o MACBA, por meio da convocação de um concurso público internacional realizado pelo Conselho Geral do Museu. Desse modo, em julho de 2015, é escolhido para o cargo o historiador da arte e curador argentino Ferran Barenblit, que o assume em outubro do mesmo ano. Entre 2003 e 2008, Barenblit dirigiu o Centro de Arte Santa Mònica (CASM) também 
em Barcelona, e, desde 2008, atuava à frente do Centro de Arte Dos de Mayo (CA2M), em Móstoles.

Vale destacar que a escolha do novo diretor mediante concurso público internacional diverge dos processos seletivos anteriores, haja vista que eram os próprios diretores quem escolhiam seus sucessores. Tal mudança, para Graell (2016), evidencia uma tentativa por parte da Prefeitura de Barcelona, à frente da qual se encontra Ada Colau, de impulsionar uma política de governabilidade mais transparente, principalmente desde a crise instaurada pelo cancelamento de A Besta e o Soberano.

Ao chegar ao MACBA, Barenblit afirmou ter se deparado com uma instituição com vinte anos de solidez e com um passado muito bem construído, materializado em uma coleção particular que representa bem sua história, uma programação de exposições e atividades bem definidas, um pensamento crítico muito importante tanto em Barcelona como fora, bem como um grande impacto internacional. $\mathrm{O}$ diretor também se referiu a uma arquitetura institucional muito ensaiada, por meio do modelo do Consórcio, que permitiria o diálogo dentro da instituição (BARENBLIT, 2015a). Ele também fez referência a um discurso próprio por parte do Museu, que diz respeito à capacidade de olhar a História da Arte da segunda metade do século XX a partir de uma posição não hegemônica, mostrando como houve muitas narrativas que ficaram ocultas, muitas vezes por força de um mercado muito institucional, mas que, com o tempo, demonstraram ter sido chaves para entender a realidade de forma global (BARENBLIT, 2015a).

Assim, o diretor destacou como tais bases foram consolidadas pelo trabalho dos quatro diretores anteriores e durante as duas décadas de funcionamento do Museu, de modo que, para ele, qualquer nova proposta teria que partir dessas premissas (BARENBLIT, 2015a). Para Barenblit, o MACBA deveria continuar sendo, acima de tudo, um serviço público, que refletisse e desenvolvesse na cidade uma cultura crítica e diversa, além de uma instituição que combinasse sua responsabilidade de olhar para o passado recente com a de construir presente e futuro mediante relatos e experiências plurais que renunciassem à narração unívoca e hegemônica. Assim, para o diretor, ao estimular o diálogo, o Museu contribuiria para a emancipação dos cidadãos, para reforçar indivíduos e coletivos que pudessem impulsionar mudanças positivas na sociedade, de modo que tais funções deveriam ser tão importantes como a de ser uma voz de primeira ordem na arte contemporânea nacional e internacional (ARTISHOCK, 2015). Desse modo, para o diretor, a internacionalização da instituição, bem como o aumento de seus públicos, não estaria entre seus principais objetivos, de modo que ele 
preferia pensar que tais conquistas acabam por ser consequências de um projeto sólido (EUROPAPRESS, 2017).

Quanto a suas propostas, o diretor afirmou que suas bases eram claras, de modo que partiriam de como o Museu se definia, quais temas vinha abordando, e o que havia tido como próprio ao longo do tempo. Para ele, esses eram elementos que não podiam ser alterados, pois eram parte da história do Museu, sua trajetória e, acima de tudo, sua coleção (BARENBLIT, 2015b).

O diretor destacou também como a situação atual do MACBA abarca uma evolução de visão. Assim, para ele, quando um museu de arte contemporânea cumpre vinte anos, deve pensar como seguir sendo contemporâneo e, para tanto, deve haver uma mudança de visão. Desse modo, de acordo com Barenblit, quando o Museu foi inaugurado e, sobretudo, quando Borja-Villel assumiu a direção, em 1998, olhava-se para uma geração que emergiu nos anos setenta, a geração conceitual catalã, que até então se tentava enquadrar em um discurso formal, de modo que, em oposição, Borja-Villel vinculou-a a um discurso muito mais político (BARENBLIT, 2015b). Após o Museu ter completado vinte anos, o diretor declara então ser o momento de transpor a centralidade dessa narrativa, dessa vez para a década de noventa, não em termos de cronologia, destaca, mas sim de visão. Isso porque, para Barenblit (2015), grande parte do mundo como o conhecemos se delineia na década de noventa (ele deixa claro que se deve respeitar as décadas anteriores), como elementos do contexto de arte atual e da cultura. Para Barenblit, o museu deve atuar como um agente de questionamento e dúvida, um lugar para se contestar politicamente o mundo. Nesse contexto, a arte atua por analogia, pensa à distância, o que converte o museu em uma maquinaria politicamente útil (BARENBLIT, 2015b).

Sendo assim, o diretor destaca que não quer promover rupturas, mas sim projetar a própria história do Museu em direção ao futuro, de modo a promover transformações baseadas no que foi alcançado nos vinte anos do percurso da instituição. Sendo assim, Barenblit declara que tudo o que fora realizado até então não deveria ser rejeitado, pois tratase de uma herança extraordinária (BARENBLIT, 2015a). Ademais, o diretor pretende que se siga despertando o espírito crítico dos visitantes, e que se consiga acolhê-los mais efetiva e emocionalmente, em oposição ao que ocorre em um espaço de produção fordista de exposições em série, caso de muitas instituições de arte atuais (EUROPAPRESS, 2015). O diretor também ressaltou a importância de não haver hierarquias entre as atividades do 
Museu, de modo que os programas públicos e educativos devem ter a mesma importância que exposições (BOSCO, 2015).

Outra proposta de Barenblit é dar mais destaque ao âmbito da performance, além de dar voz às culturas populares, especialmente no contexto de Barcelona, que, de acordo com o diretor, conta com uma importante cena underground. Ele declarou também que um de seus empenhos passa por conseguir um trabalho em equipe por parte de todos os trabalhadores da instituição (EUROPAPRESS, 2017).

No comunicado institucional do Museu referente aos anos de 2016/2017, declara-se como, em um contexto como o atual, marcado pelo desenvolvimento do capitalismo cognitivo, no qual o conhecimento está permanentemente ameaçado por sua mercantilização e privatização efetiva, e determinado pela deriva em direção à espetacularização da cultura, entendida como recurso de atração turística e de ativação econômica, mais que como um espaço de ativação de subjetividades, torna-se essencial pensar a respeito dos modos por meio dos quais o Museu produz suas atividades e seus programas educativos. Para tanto, alega-se que o MACBA inicia um processo de reflexão a fim de situar sua prática pedagógica e programas públicos em posições centradas na experiência e que ultrapassem qualquer aproximação com a noção de conhecimento como acúmulo individual de saber. Assim, de acordo com a declaração, os programas do MACBA pretendem suprimir a tradicional divisão da população em distintos públicos consumidores da cultura e objetos da educação para desenvolver um trabalho transversal com diversas comunidades e agentes de seu contexto. Nesse sentido, um dos objetivos do Museu é ser relevante para a experiência vital do público, o que há de ser posto em prática mediante o estabelecimento de redes de trabalho flexíveis, duradouras e horizontais, que dotem a instituição da capacidade de gerar espaços de investigação, experimentação e colaboração permanentes. A partir dessa premissa, ainda de acordo com o documento, o MACBA começaria a pensar e atuar menos como uma instituição com identidade fixa e mais como um espaço atravessado pelas forças que o rodeiam, pois apenas a partir da interrelacionalidade e a vulnerabilidade o Museu poderia se converter em um lugar a partir do qual reverter os padrões de conduta impostos e produzir relatos micropolíticos resistentes às grandes narrativas estabelecidas. Por fim, observa-se como é interessante pensar os modos como os espaços, mesmo que se articulem normativamente, nunca estão determinados por completo e podem, portanto, ser transformados de acordo com as necessidades que o utilizam. Desse modo, o Museu não pensaria seus programas como 
produtos finitos, mas partiria do entendimento de que esses são construídos com base em ações e encontros com os cidadãos (MACBA, 2016a).

Quanto aos possíveis conflitos com relação aos membros do Consórcio, o diretor acredita que seja perfeitamente possível articular a administração pública e a iniciativa privada, desde que se tenha em mente que o objetivo é promover um serviço público (BARENBLIT, 2015b).

Quanto às relações do MACBA com o Raval, essas são, para o diretor, fundamentais ao Museu, de modo que ele acredita na necessidade de se travar um diálogo mais intenso com essa comunidade. Para o diretor, trata-se de um bairro submetido a muitas contradições, de modo que possui áreas muito gentrificadas e outras nem tanto, contexto em que acredita que o Museu deve estabelecer um contato maior, não apenas com a realidade do bairro, mas também com seu imaginário. Desse modo, trata-se, para o diretor, de um dos grandes espaços pendentes de reflexão (BARENBLIT, 2015b)

\section{Novas incorporações à equipe e ao Comitê Assessor}

Em outubro de 2016, mediante processos abertos de seleção, o MACBA incorpora a sua equipe Tanya Barson, como conservadora chefe, Pablo Martinez, como chefe do Departamento de Programas Públicos, e Josep M. Carreté, à frente da gerência do Museu. É formado também um novo Comitê Assessor, constituído por Catherine David, Chris Dercon, Estrella de Diego e Cuauhtémoc Medina, a fim de que esses experientes profissionais contribuam com a planificação de longo prazo no MACBA (MACBA, 2016a).

\section{Sobre a crise de $A$ Besta o Soberano}

Quando questionado sobre a polêmica gerada pelo cancelamento de A Besta e o soberano, o diretor declarou que acredita que, às vezes, espera-se demais da figura do diretor de um museu, e que não se pode considerá-los "caudilhos todo-poderosos" (BARENBLIT, 2015a). Assim, ele considera o contexto institucional como um jogo político, marcado pelo diálogo, pontos de encontro, de visibilidade e conflitos, situação que considera desejável. Ainda, destaca que o diretor está em contínua negociação, e que se deve lutar contra a inércia da previsibilidade de um museu (BARENBLIT, 2015a). O diretor afirmou também que se exige demasiado dos diretores, como por exemplo, que seus projetos sejam radicalmente pessoais, de modo que, pelo contrário, ele acredita muito na figura da instituição como um 
todo (BARENBLIT, 2015b). Barenblit declarou defender elementos como autonomia e negociação, mas jamais censura (EUROPAPRESS, 2015).

\subsubsection{Programa a partir de 2016}

A seguir, analisamos as atividades realizadas durante a gestão de Ferran Barenblit como diretor do MACBA. Como vimos, esse assume o cargo em outubro de 2015, momento em que já havia uma programação em curso, elaborada durante a gestão anterior, para os anos entre 2014 e 2016. Vale assinalarmos também que a demissão de Valentín Roma do cargo de curador chefe e de Paul Preciado do cargo de diretor de Programas Públicos gerou a necessidade de alterações no programa do Museu (PUIG, 2015). Desse modo, foram canceladas exposições como La escritura es un virus, que pretendia analisar a relação entre escritura e arte a partir da obra de William Borroughs, além de Arte y escritura, que consistia em um projeto pessoal de Valentín Roma (PUIG, 2015). Também a artista Itziar Okariz, que realizaria uma instalação no Gran Vidrio do Museu, negou-se a colaborar com a instituição após a controvérsia gerada pelo cancelemento de A Besta e o Soberano. Quanto à exposição de Sergi Aguilar Revers/Anvers (1972-2015), retrospectiva da obra escultórica do artista barcelonês, Valentín Roma, que a idealizou, pediu para que seu nome como responsável fosse omitido (PUIG, 2015). Também foi cancelado o seminário dirigido por Marcelo Expósito, que levaria palestrantes como Naomi Klein (PUIG, 2015).

Assim, nas páginas seguintes, elencamos as atividades realizadas durante os anos de 2016, que Ferran Barenblit inicia já alocado ao cargo, e de 2017, tendo em mente possíveis nuances entre esses períodos, já que, como ressaltamos, grande parte da programação da gestão anterior se estendia até o ano de 2016, salvo algumas mudanças, como as acima mencionadas, sendo que algumas das propostas chegaram ao fim em 2017. Ainda assim, em 2016, é lançado, como citamos, um documento elaborado pelo novo diretor, acerca das diretrizes para as atividades a serem realizadas nos próximos anos.

Assim como Bartomeu Marí, o novo diretor, ao considerar o MACBA como uma instituição sólida e com um passado bem construído, reconheceu a importância de partir das premissas previamente estabelecidas na instituição por seus antecessores ao realizar as propostas para a nova gestão. Desse modo, ao analisar as atividades realizadas durante a gestão de Barenblit (entre 2016 e 2017), tomamos novamente como linhas gerais as diretrizes estabelecidas durante a gestão de Borja-Villel, buscando mapear a continuidade de experimentações institucionais no Museu. 


\section{Modificar a narrativa sobre a História da Arte por meio da coleção e do programa de exposições}

Como vimos, uma das propostas chave da gestão de Borja-Villel, continuada ao longo da gestão de Bartomeu Marí, foi a realização de exposições e aquisição de obras e documentos que proporcionassem uma revisão da narrativa hegemônica da História da Arte, e também de modo a evidenciar o trabalho de artistas muitas vezes por ela marginalizados. Nesse sentido, destacamos algumas exposições que acreditamos que se enquadram nesse objetivo (Ver Anexo G), tais como: José Antonio Hernández-Díez. No Temeré Mal Alguno, realizada entre março e junho de 2016, em que foram apresentadas obras do artista venezuelano, que cultivava a ideia da arte contemporânea como uma linguagem global, e procurou questionar o domínio dos artistas europeus e norteamericanos (MACBA, 2016b); Punk. Sus Rastros en el Arte Contemporáneo, que consistiu em um percurso através da influência do punk sobre a arte atual, destacando a importância de sua presença como atitude e referência para muitos criadores (MACBA, 2016c); Andrea Fraser. L'1\%, C'est Moi, realizada no MACBA entre abril e outubro de 2016, foi a primeira exposição monográfica de Andrea Fraser na Espanha. Sua obra examina as motivações de um amplo leque de agentes culturais, além de estar vinculada à crítica institucional, e influenciada pelo feminismo, a psicanálise e a teoria dos campos sociais do sociólogo Pierre Bordieu, de modo que constitui uma análise penetrante do tecido social do mundo da arte (MACBA, 2016d); Miralda MADEINUSA, realizada entre outubro de 2016 e abril de 2017, que buscou recuperar a totalidade dos projetos do artista espanhol Antoni Miralda relacionados a sua estadia nos Estados Unidos, bem como dimensionar a vontade coletiva que caracteriza a metodologia do artista, centrada na participação, na ideia de ritualidade ou cerimônia, e na gastronomia (MACBA, 2016e); Gelatina Dura - Historias Escamoteadas de los 80, que pretendeu abordar o período entre 1977 e 1992, de modo a evidenciar histórias ignoradas pelos relatos oficiais do período, abordando a cultura underground dos setenta, que se manifestava em meio à clandestinidade e à censura, e que, nos oitenta, passa a ditar a reformulação crítica das próprias práticas culturais (MACBA, 2016f); Muestreo \#1 - Los Documentos a Escena, realizada entre abril e setembro de 2017 no espaço térreo do CEDOC, que apresentou um conjunto de materiais advindos das coleções e fundos documentais do Arquivo MACBA, no que pretendeu ser um exercício cotidiano de abertura de conteúdos que habitualmente 
permanecem velados sob as condições de conservação e acesso próprias do tratamento arquivístico (MACBA, 2017a); Akram Zaatari - Contra La Fotografía. Historia Anotada De La Arab Image Foundation, realizada entre abril e setembro de 2017, a partir do arquivo da Arab Image Foundation (AIF), em Beirute, no Líbano, que contém material fotográfico proveniente do Oriente Médio, Norte da África e da diáspora árabe, e foi criada por artistas preocupados com a preservação fotográfica, a fim de atuar como um centro dedicado ao estudo da fotografia e às práticas de colecionismo, preservação e divulgação de imagens (MACBA, 2017b); Poesía Brossa, revisão do trabalho do artista catalão através de seus livros e investigações plásticas, aque atravessam a poesia, o teatro, o cinema, a música e as artes de ação. Joan Brossa (Barcelona, 1919/98), desenvolveu sua prática artística desde os anos quarenta, em um contexto sociopolítico marcado pela ditadura franquista e em uma situação cultural caracterizada pela ausência de propostas vanguardistas e inovadoras (MACBA, 2017c); Rosemarie Castoro. Enfocar al Infinito, retrospectiva acerca da obra da artista estadunidense, centrada no período entre 1964 e 1979, cuja intenção foi demonstrar como algumas das figuras mais relevantes do minimalismo não receberam a atenção que merecem, especialmente o grupo de mulheres artistas pertenecentes a um movimento erroneamente identificado como essencialmente masculino. Como consecquência, a exposição assinalou a necessidade de se repensar o minimalismo, expandindo-o para incluir um maior número de artistas e a fim de questionar os relatos hegemônicos do movimento (MACBA, 2017d).

\section{Abordagem de questões políticas no Museu}

Outra das diretrizes propostas por Borja-Villel, e que pretendemos localizar na gestão de Ferran Barenblit, é a de suscitar a discussão de questões políticas no âmbito do MACBA. Nesse sentido, encontramos tal intenção tanto por meio da realização de algumas exposições, como pela organização de conversas, mesas redondas, conferências e seminários no Museu (Ver Anexo H). Sendo assim, aqui elencamos: Forensic Architecture - Hacia Una Estética Investigativa, exposição sobre os trabalhos do grupo de pesquisadores baseado em Londres Forensic Architecture, coproduzida junto ao MUAC, e realizada entre abril e outubro de 2017. Suas pesquisas revolvem em torno de violações dos direitos humanos em escala global, de modo que apresentam provas evidentes aos tribunais internacionais, colaborando com grupos ativistas, organizações como a Anistia Internacional e as Nações Unidas (MACBA, 2017e); Colección MACBA. Martha Rosler: God Bless America!, exposição realizada entre maio e 
outubro de 2017, que se centrou sobre a produção videográfica de Matha Rosler, através de onze obras realizadas desde os anos setenta até 2006, trataram de temas como imigração, exploração laboral, a cumplicidade entre as corporações multinacionais, o governo dos Estados Unidos e os regimes ditatoriais da América Latina, e as transgressões da vida privada cometidas pelo poder do Estado e análises de gênero (MACBA, 2017f); Procesos Constituyentes. Hacia una Nueva Democracia en Europa - Materiales para la Discusión desde Latinoamérica y el Espacio Político Europeo, encontro organizado pelo MACBA em março de 2016, junto à Hidra Cooperativa e à Fundación de los Comunes, que objetivou contribuir com experiências e reflexões a partir dos processos constituintes latino-americanos das últimas décadas, em particular Equador e Bolívia (MACBA, 2016g); Máquinas Constituyentes: Poder Constituyente, Biopolítica, Democracia, conferências realizadas dentro do programa Máquinas constituyentes: poder constituyente, biopolítica, democracia, cujo objetivo foi compreender a situação de múltipla cirse institucional na qual se encontra o projeto da União Europeia e sua retroalimentação pela crise sistêmica do capitalismo e as bifurcações enfrentadas pela economia global; Los Ochenta a Contrapelo, seminário internacional realizado em dezembro de 2016, que propôs uma revisão do passado recente da Europa, em especial a década de oitenta, mediante a abordagem de temas como a espiral crescente de desigualdade, a desindustrialização, as grandes regiões empobrecidas, os desequilíbrios Norte-Sul, a instrumentalização da cultura e o e crescente fantasma do fascismo que assombra a Europa (MACBA, 2016h); Barcelona Wars: Del Imperio de los Rentistas al Contra Ataque Vecinal, curso realizado entre dezembro de 2016 e janeiro de 2017, que tratou da desenfreada atuação da especulação, em Barcelona, sobre o aumento dos custos de habitação (MACBA, 2016i); Crisis Global y Teoría Urbana Crítica, seminário realizado em março de 2017, que propôs abordar debates centrais da teoria urbana na atualidade: a expansão da urbanização, a dialética multiescalar centro-periferia e a emergência de movimentos sociais urbanos, além de questionar, quando necessário, o papel da hegemonia teórica angloamericana na definição dos grandes temas de reflexão (MACBA, 2017g); Economía y Ecología Política Del Turismo, curso realizado entre março e abril de 2017, que pretendeu fortalecer a análise crítica do turismo a partir das perspectivas da economia e da ecologia política, de modo a formar um espaço de debate comprometido com as necessidades e direitos dos cidadãos sobre seu território e seus recursos (MACBA, 2017h); Poner a las Mujeres en el Centro para Pensar el Presente. Violencia, Comunidad y Estado en el Siglo $X X I$, encontro em que se propôs pensar o mundo desde a perspectiva das mulheres, seu 
posicionamento determinado nas sociedades e a forma como se vêem afetadas pelas políticas públicas e de mercado (MACBA, 2017i); La Revolución Jurídica de los Bienes Comunes, curso realizado entre abril e maio de 2017, que teve como principal objetivo compartilhar estratégias políticas e ferramentas jurídicas para defender os bens comuns; 365 Días de Trabajo Invisible, Mesa de debate realizada em dezembro de 2017 pela defesa dos direitos dos trabalhadores domésticos, de limpeza e de cuidados (MACBA, 2017j).

\section{A articulação entre as exposições, a coleção e as atividades de Programas Públicos}

Como vimos, trata-se de uma das diretrizes estabelecidas desde a gestão de BorjaVillel, continuada pela de Bartomeu Marí, e que também pudemos observar na nova gestão, de modo que se verifica a constante intenção em integrar as diferentes atividades realizadas no Museu. Nesse sentido, pudemos observar a realização de conversas a respeito de exposições, como aquela entre a artista Andrea Fraser e o curador Cuauhtémoc Medina, realizada em abril de 2016, a respeito da inauguração da exposição L'1\% c'est moi no Museu (MACBA, 2016j) e entre a curadora da mostra Akram Zaatari. Contra la fotografía. Historia anotada de la Arab Image Foundation, Hiuwai Chu, e o artista Akram Zaatari, sobre as múltiplas condições dos documentos fotográficos, sua inscrição no discurso artístico e a posibilidade de gerar novas leituras e relatos a partir deles (MACBA, 2017k). Também foram realizadas visitas pelas exposições com curadores e artistas, como pela exposição No temeré mal alguno, em abril de 2016, com os curadores da mostra, o artista José Antonio HernándezDíez e o restaurador Lluís Roqué, que pretendeu funcionar como um espaço de conversação e diálogo sobre alguns dos aspectos menos conhecidos das obras que integravam a exposição (MACBA, 2016k). Destaca-se também a realização de ciclos de cinema a propósito de exposições, como Sombras y Silencios o los Fantasmas que Vuelven como la Primera Vez, organizado, entre maio e junho de 2016, pelo cineasta Andrés Duque, a propósito da exposição de José Antonio Hernández-Díez, em que o cineasta propôs a exibição de um grupo de filmes que produzissem o mesmo assombro sobrenatural que sentiu ao ver as obras expostas pela primeira vez na Galería de Arte Nacional de Caracas (MACBA, 20161) e Los ochenta, ficciones de um futuro anterior, realizado, entre fevereiro e março de 2017, paralelamente à exposição Gelatina dura. Historias escamoteadas de los 80, e organizada pelo MACBA junto à Filmoteca de Catalunha, em que foram apresentadas distintas ficções que resgatam certo espírito dos oitenta (MACBA, 20171). 
Também foram realizadas oficinas educativas, voltadas ao público geral, no contexto das exposições em cartaz, como Con la comida también se juega, atividade direcionada a crianças de 1 a 5 anos e realizada, entre novembro e dezembro de 2016, no contexto da exposição Miralda Madeinusa, e que pretendeu imaginar outras formas de celebração e experimentação com os sentidos. A respeito da mesma exposição, foi realizada também a oficina El Festín, dessa vez direcionada para crianças de 6 a 13 anos, em que se propôs a ativação de um espaço de liberdade, experimentação e aprendizagem coletivos (MACBA, 2016m).

Vale comentar também a apresentação de performances no espaço do MACBA, no contexto de exposições, tais como Box Sized DIE featuring Caustic, ativação da peça Box Sized DIE, do artista João Onofre, e que fazia parte da exposição PUNK. Sus rastros en el arte contemporâneo, pela banda de death metal Caustic (MACBA, 2016n) e Poéticas del Signo y del Détour, jornadas realizadas em janeiro de 2017, que visaram ativar a instalação Santa Comida, de Antoni Miralda, exposta no contexto da exposição Miralda Madeinusa, mediante um programa que combinou a conversação, o concerto performático, a deriva na cidade e o encontro em torno da comida em comum (MACBA, 2017m); o Programa de dança com Yvonne Rainer, por ocasião da exposição retrospectiva de Rosemarie Castoro, que contou com a realização de uma conferência-performance no auditório do Museu e a apresentação, no espaço Mercat de les flors, The Concept of Dust: Continuous Project - Altered Annually, trabalho que interrelaciona a dança formal com textos que tratam do envelhecimento e da morte, histórias pessoais e materiais (MACBA, 2017n).

Ainda a propósito da articulação entre as exposições, a coleção e as atividades de Programas Públicos, verificou-se a realização de debates, conferências e seminários relacionados a exposições em cartaz, como o seminário Encarnar la Crítica Institucional, ministrado por Andrea Fraser e Helmut Draxler, a propósito da exposição L'1\% C'est Moi (MACBA, 2016o); o debate Evidencia, Activismo y Ley en la Era de la Posverdad, realizado no contexto da exposição Forensic Architecture, que teve como objetivo refletir sobre o uso da evidência, do ativismo, do direito e da política na chamada era da pós-verdade (MACBA, 2017o); o seminário Estética Investigativa, Acontecimento y Huella, realizado paralelamente à exposição Forensic Architecture. Hacia una estética investigativa, em se pretendeu aprofundar o sentido das investigações artísticas para a reivindicação da defesa dos direitos humanos, assim como na introdução de temas de importância crucial na esfera pública, como 
o ecocídio e a destruição do meio ambiente (MACBA, 2017p); a conferência ministrada por Martha Rosler a propósito da exposição God Bless America!, em que a artista buscou examinar, desde sua posição crítica e perspectiva feminista, o papel do trabalho documental no atual contexto da pós-verdade (MACBA, 2017q).

\section{Educativo}

Quanto às atividades educativas, em 2016 e 2017, continuam os projetos de formação de professorado para profissionais de todos o níveis de ensino, por meio de cursos e oficinas, com o intuito de estabelecer relações entre os temas abordados no Museu e na sala de aula, introduzir noções básicas de arte contemporânea aos professores, além de utilizar a arte para estabelecer diálogos e suscitar a discussão de temas importantes. Como exemplos temos o curso Arte, Museos y Escuela. Creación y conocimiento en red realizado em fevereiro de 2016 e dirigido a professores de educação infantil, primária e secundária, junto ao grupo Amb Sense Art i Escola, que faz parte do Institut de Ciències de l'Educació da UAB, e que teve como objetivo estabelecer pontes de mediação entre os centros educativos e as instituições culturais; as atividades Te acercamos a las exposiciones, sessões preparatórias para os professores, a fim de prepará-los para posteriores visitas com seus grupos escolares às exposições; a oficina Tu abuelo era um colono, realizada em setembro de 2017 e voltada para professores de ensino médio e universitário, concebido como espaço de coaprendizagem, educação antirrascista e crítica, que se utilizou da história como ferramenta narrativa para pensar a questão das heranças identitárias, por meio de dinâmicas corporais; o curso Aquí se acaba la visita, voltado para professores de todos os níveis educativos, que propôs uma aproximação ativa à Coleção do MACBA, suscitando diálogos com relações às obras expostas, visando tanto o conhecimento das propostas criativas desde os anos sessenta até a atualidade, como a experimentação com suas principais linhas temáticas, como corpo, ação, espaço, tempo, arquivo e conflito (MACBA, 2017r). Continua também o projeto Expressart, voltado para grupos escolares de todos os níveis, e que, como vimos, consiste em uma atividade educativa combinada a uma visita ao Museu.

Entre eventos que abordaram questões educativas, destacamos o seminário Focusing On The Learner. La Filosofia Diylab en la Escuela y en la Universidad para Fomentar la Acción de los estudiantes y el aprendizaje colaborativo, realizado em novembro de 2016 e organizado pelo coletivo Esbrina, da Universidade de Barcelona, que explorou a 
popularização do movimento do it yourself (DIY), ou "faça você mesmo". Diante disso, exige-se um novo panorama de recursos para incluir, em diferentes contextos educativos, a produção de novos meios vinculados às exigências da era digital. Sendo assim, o simpósio teve como objetivo problematizar e interrogar acerca das possibilidades e limites da introdução da filosofia DIY no ensino primário e secundário, assim como nas universidades (MACBA, 2016p).

Vale destacar também a realização, a partir de outubro de 2017 (previsto até junho de 2019) do projeto Interferencias sonoras, voltado para escolas e institutos do Raval de ensino médio, universitário e ciclos de formação, cujo objetivo é combinar práticas artísticas e educativas, por meio de atividades experimentais a partir das quais sejam exploradas metodologias e formatos múltiplos de atividades em rede. Trata-se da intenção de trabalhar junto ao ecossistema educativo que rodeia o MACBA, por meio de práticas mais flexíveis, arriscadas e radicais, e menos estáticas (MACBA, 2017s). O programa do projeto para 20172018 é trabalhar junto ao coletivo artístico Poderío Vital, a partir de ideias como a escultura vibracional e a simbiose sinfônica, e de modo a pensar ações como passear musicalmente pelo Museu e investigar aquilo que se vive sonoramente no espaço público (MACBA, 2017s).

Para o público geral e espontâneo, também continuaram a ser realizadas diversas oficinas para crianças, adolescentes, adultos ou famílias, bem como visitas guiadas. Como exemplos, temos: El Pesanervios, oficina de performance ministrada por Joan Morey em julho de 2016 (MACBA, 2016q); Historias Secretas de un Habitáculo, visita-ateliê realizada durante o mês de fevereiro de 2016, em que as famílias com crianças a partir de 6 anos foram convidadas a aproximar-se do Museu e nele projetar sua realidade cotidiana e também imaginária, assim como construir um lugar comum, ideal e fantástico entre o desenho, a instalação e a performance (MACBA, 2016r); Autoedición, Anarchivo, Fotozines, oficinaconversa organizada em fevereiro de 2016 por La Fanzinoteca, projeto desenvolvido por Ricardo Duque e Lluc Mayol, que se articula a partir de um arquivo de fanzines, hand-made books e outras edições de difícil classificação, com o objetivo de difundir esse tipo de publicações e promover um espaço de prática, estudo e reflexão sobre elas (MACBA, 2016s); MACBA Collage Lab, oficina realizada em março de 2016, que pretendeu atuar como espaço de experimentação, reflexão e prática da collage, conduzido por Max-o-matic, artista especializado na técnica (MACBA, 2016t); El Raval Siempre Estuvo Aquí, oficina de manipulação de antigas fotos do Raval por meio da técnica croma, que possibilita a inserção de objetos e personagens nessas imagens. Realizado em abril de 2016 (MACBA, 2016u); 
Laboratorio artístico, atividade realizada em outubro de 2016, direcionada a crianças de 6 a 13 anos, que partiu da aproximação entre museu e laboratório, propondo uma visita pelas obras Entrevendo de Cildo Meireles e Eisring y Condensation Cube, de Hans Haacke, seguida de atividades relacionadas (MACBA, 2016v); No Trabajéis Nunca, oficina voltada para famílias, realizada em abril de 2017, que buscou trabalhar questões como: que novas relações e significados podem surgir do deslocamento de conceitos e ações que parecem inalteráveis, como o trabalho, o tempo produtivo ou improdutivo, a eficácia, a ausência, o útil e o inútil? (MACBA, 2017t).

\section{Habitació 1418}

Tem continuidade, na gestão de Barenblit, o programa de Habitació 1418, realizado pelo MACBA em conjunto com o CCCB, e direcionado a adolescentes entre 14 e 18 anos. Foram propostas e realizadas pelo programa, em 2016 e 2017, atividades colaborativas como: $P I(E) C E$, oficina realizada de janeiro a junho de 2016, em que os participantes aprenderam a elaborar a música para um espetáculo teatral. A atividade fez parte do projeto de criação participativa PI(E)CE, fomentado pelo Teatro Tantarantana de Barcelona, com o intuito de reunir jovens e adultos dos bairros de Raval, Poble Sec e Ciutat Vella, implicando os institutos Consell de Cent e Milà i Fontanals, para a realização de uma nova peça teatral (MACBA, 2016w); El Raval: Sonido, Tiempo y Espiar, que consistiu na realização, em julho de 2016, de um percurso sonoro pelo Raval, que incluiu uma "viagem no tempo", mediante o uso de um arquivo de áudio, buscando uma aproximação dos participantes com relação às ruas do bairro e suas histórias, que, muitas vezes, passam despercebidas (MACBA, 2016x); ¡Bienvenidas!, atividade realizada, em setembro de 2016, em colaboração com o projeto Tallers Oberts del Poblenou, que organiza visitas aos estúdios de artistas do bairro, de modo a aproximar seus trabalhos do público. Também foi realizada uma atividade de pintura mural aberta e participativa (MACBA, 2016y); GRAFI_SISMOS, Oficina de produção gráfica de cartazes, camisetas, máscaras, bandeiras, etiquetas, entre outros formatos, nos quais os participantes foram convidados a estampar suas mensagens (MACBA, 2016z); ;Basta de Sexismo!, oficina ministrada, em novembro de 2016, pelo grupo feminista de trap Las VVitch, em que foram apresentados e colocados em prática todos os seus processos de criação musical, desde a busca de uma base instrumental à gravação e mistura de vozes, com ênfase na criação de letras com perspectiva de gênero (MACBA, 2016aa); Todos lo Saben, 
oficina de comunicação ministrada por membros das equipes do CCCB e do MACBA, realizada em janeiro de 2017, que tratou de estratégias de comunicação para a festa a ser desenvolvida conjuntamente pelos participantes do projeto Habitació 1418, de modo que foram pensadas, questionadas e construídas estatégias comunicativas para o evento (MACBA, 2017u); Face the Strange Party, realização da festa de celebração dos três anos do projeto Habitació1418, em fevereiro de 2017, no CCCB, a qual foi criada e programada integralmente por seus participantes. O evento contou com a apresentação do grupo Las VVitch, DJ's, instalações, experimentos sonoros, espectáculos de luzes e projeções. A festa foi pensada também como uma gincana em que os participantes teriam que percorrer os diferentes espaços (fases) que questionam os processos e etapas da criação artística e da transformação das ideias (MACBA, 2017v); COSMOBILIS, oficina de composição poética ministrada pelo poeta Josep Padrals a partir da deconstrução de textos e da escrita não linear e visita à gráfica L'Automàtica para imprimir, à maneira de Gutenberg, a obra coletiva realizada na oficina (MACBA, 2017w); Videoclip'me, projeto de gravação de um videoclipe do grupo Vvitch, desenvolvido pelos participantes da Habitació 1418 junto à produtora Matroska Productions, em maio de 2017 (MACBA, 2017x); Fanzines con Doza Electrónica, oficina realizada em outubro de 2017, em que foram executados exercícios a partir de dispositivos móveis, como materiais para a geração de novas imagens e narrativas, além de conversas sobre desenho, maquetação e edição analógica, de modo a ilustrar alguns experimentos editoriais (MACBA, 2017y); Microrracismos, oficina ministrada por Antoinette Torres Soler, professora, fundadora e diretora da revista digital Afroféminas, em julho de 2017, que pretendeu refletir sobre as percepções geradas com relação aos afrodescendentes no dia a dia (MACBA, 2017z); Taller Visual A - PART, oficina realizada em outubro de 2017, que buscou expor e debater coletivamente nomes femininos que não aparecem na História da Arte canônica e acadêmica. Por meio da técnica de collage, buscou-se elaborar um eixo cronológico dadaísta no qual as artistas, pensadoras e agitadoras culturais fossem mulheres, de modo a redescobrir figuras femininas que permaneceram eclipsadas ao longo da História (MACBA, 2017aa); Taller de Autodefensa Verbal para Contestar a Señores y Defenderse en Situaciones Machistas, oficina realizada em outubro de 2017, na qual foi abordado o machismo em diferentes contextos, de modo a suscitar o debate quanto aos modos como ele afeta a vida tanto de meninas como de meninos. Também foi realizada uma aula de autodefesa intelectual e verbal com o intuito de preparar respostas inteligentes em casos de machismo (MACBA, 2017bb). 


\section{Visitas Guiadas}

Em 2016, continuaram também a ser realizadas diversas atividades de visitas guiadas às exposições em cartaz no Museu para o público geral, geralmente com os curadores das mostras, e muitas vezes com os artistas participantes. Desse modo, foram realizadas: visita à exposição No temeré mal alguno, realizada pelo artista José Antonio Hernández-Díez e o grupo Latitudes (Mariana Cánepa Luna y Max Andrews), curadores da mostra, em março de 2016; visita à exposição Andrea Fraser. L'1\% C'est Moi, liderada por seu curador, Cuauhtémoc Medina, em abril de 2016; visita com David G. Torres, curador da exposição Punk. Sus Rastros En El Arte Contemporáneo, em junho de 2016. Foram realizadas também visitas guiadas exclusivas aos associados ao programa Amigos MACBA.

Em 2017, observamos que aumentaram as visitas exclusivas aos Amigos e diminuíram aquelas abertas ao público geral. Desse modo, foram realizadas: visita comentada à exposição Akram Zaatari. Contra la fotografia. Història anotada de l'Arab Image Foundation, realizada por Hiuwai Chu, co-curadora da exposição (MACBA, 2017cc); visita comentada à exposição Fenómeno Fotolibro, no $\mathrm{CCCB}$, realizada por Moritz Neumüller; visita comentada à exposição Rosemarie Castoro. Enfocar al infinito, pela curadora da mostra, Tanya Barson (MACBA, 2017dd). Em ocasiões como o Dia Internacional dos Museus, o MACBA ofereceu entrada livre às exposições em cartaz, realizadas pela equipe de restauração do Museu, bem como às reservas, a cargo da equipe responsável, e ao Arquivo e Biblioteca, realizadas pelos funcionários do CEDOC.

\section{Museu Cerrado}

Em janeiro de 2016, é inciado um novo projeto do MACBA, The Museum is Closed, que consiste na realização de uma oficina mensal no Museu, às terças-feiras, em que ele permanece fechado, e cujo objetivo é dar espaço aos artistas, coletivos e curadores para que falem de seus projetos, de modo a promover trocas e diálogo. Entre 2016 e 2017, o projeto contou com participantes como (Ver anexo I): Salah Malouli, o coletivo Leland Palmer, Jesús Palomino, O/A artista Hector Acuña/Frau Diamanda, o coletivo argentino Etcétera, a rede Translocalia, o coletivo CaldodeCultivo. 


\section{Incentivo à Performance}

Como vimos, entre os diferenciais das propostas de Ferrán Barrenblit, estava a intenção de dar mais destaque ao âmbito da performance, de modo que notamos um aumento na realização de intervenções performáticas no Museu, entre 2016 e 2017. Como exemplo, temos: Imagen Cinematográfica, Color e Improvisación, apresentação dos trabalhos performativos do artista Malcolm Le Grice, representado na coleção MACBA pela obra Berlin Horse, realizada em junho de 2016, na Capela dels Àngels, no contexto do Loop Festival (MACBA, 2016bb); Before the Name, performance apresentada, em junho de 2016, pela artista Francesca Banchelli, nas galerias do Museu, e que consistiu em uma investigação acerca da teroia do filósofo francês Alain Badiou sobre a relação entre dança e pensamento. (MACBA, 2016cc); Intervenciones en la Historia Anotada de la Arab Image Foundation, série de intervenções realizadas, em junho de 2017, por Yasmine Eid-Sabbagh, em que se popôs refletir sobre o status de uma coleção de fotografia digital procedente de Burj alShamali, um campo de refugiados palestinos do sul do Líbano (MACBA, 2017ee); LOREM IPSUM, Série de propostas apresentadas ao longo do mês de julho de 2017, que envolveram música, performance, investigação artística, experimentação, operações de deslocamento de linguagem, significados, gestos e objetos, em busca de uma extravagância sonora (MACBA, 2017ff).

Destaca-se também Idiorritmias, programa de performances, música, poesia, laboraório e texto realizado em maio de 2017. O evento enfatizou o trabalho de Itziar Okariz, por meio da ativação de cinco de suas performances. Paralelamente, Okariz participou de um laboratório, junto ao artista Quim Pujol, no qual foram trabalhados diversos aspectos relacionados à ideia de processo, performance e os pontos de encontro entre essa e diferentes práticas artísticas. Também dentro do programa de Idiorritimias, foram apresentadas: a conferência-performance de Danae Theodoridou, em que a artista partiu das obras One Small Step for a Man: Hello, Goodbye (2015) e Earth in 100 Years (2016), de modo a refletir sobre o conceito de imaginários sociais; a realização da ação Subversive Body (2016), por Aimée Zito Lema, que parte de uma série de fotografias históricas nas quais se faz presente a figura de distintas figuras que lutaram contra regimes ditatoriais, particularmente na Argentina, e na qual a artista cobre cuidadosamente corpos de participantes voluntários (MACBA, 2016dd). Outra atividade ligada à performance foi Cabaret, que consistiu em apresentações de 
espetáculos de variedades, em outubro de 2017, baseados no espírito subalterno e subversivo de Joan Brossa, inspirados na cultura da noite: fértil, irreverente e anárquica, e que contou com transformismo, strip-tease, magia, música e poesia. Foram apresentafdos: o show El mundo por montera, por Rodrigo Cuevas, uma zarzuela ${ }^{11}$ em que o artista mantém as constantes fundamentais que conformam sua proposta pessoal, que abarca o humor, o erotismo e a diversidade musical; Amateurismos. Acciones para un coro, por Jorge Dutor e Guillem Mont de Palol, um jogo de ida e volta entre o popular e o espectacular, o cotidiano e o eventual, partindo da obra de Joan Brossa e jogando com ferramentas compartidas, linguagem, som e significação; Bomberos con grandes mangueras, por Pere Faura, peça que revisita o imaginário pornográfico como prática coreográfica (MACBA, $2017 \mathrm{gg})$.

\section{MACBA Se Vive}

Tem continuidade, até o final de 2016, o programa MACBA se vive em que, como vimos, são propostas atividades de aproximação à arte contemporânea, dança, música, cinema e performance, realizadas aos sábados no Museu. No período analisado, foram realizadas atividades como: Lluvia De Sonidos en la Capella, concertos apresentados pelo grupo de percussão da Escola Superior de Música de Catalunya (ESMUC) na Capela MACBA, em janeiro de 2016, junto à instalação site-specific de Carlos Bung (MACBA, 2016ee); apresentação da proposta Museo de Futuros Naturales, de Natalie Jeremijenko, artista e engenheira centrada em temas ambientais e urbanos, no contexto da jornada Insectos sociales: aprendizajes comunes y polinización por el cambio, organizada junto ao $\mathrm{CCCB}$, em fevereiro de 2016, pouco após a celebração da reunião de cúpula COP21 do câmbio climático, em Paris. Jeremijenko mostrou alguns aspectos de seu trabalho e compartilhou parte de ações empreendidas em colaboração com vizinhos e entidades do Raval (MACBA, 2016ff); apresentação, em outubro de 2016, da artista sonora Agnès Pe, que trabalha o som para além dos limites consagrados por qualquer gênero musical, de modo que sua obra se caracteriza por uma atitude de diversão que cobre os parâmetros da música lo- $f i$ e plunderfónica, sempre buscando novas formas de relacionar-se com os elementos que recompõe mediante a atonalidade, melodias alteradas e texturas sibilantes (MACBA, 2016gg); La Tribu Inefable, apresentação, em outubro de 2016, do grupo de dança La Tribu Inefable, formado por jovens

\footnotetext{
${ }^{11}$ Obra dramática e musical em que se alternam cenas cantadas e faladas em espanhol, a fim de tornar mais compreensível o desenvolvimento do argumento (TEATRO MAYOR, online).
} 
com e sem diversidade funcional, incorporado à Orquestra Integrada, projeto da ONG ARTransforma que une jovens músicos em um processo criativo conjunto. No MACBA, o grupo trabalhou também junto ao coreógrafo Jordi Cortés e os músicos Santi Carcasona e Queralt Prats, em um processo que fomentou o encontro, a inclusão, a criatividade individual e grupal, explorando o vínculo entre as pessoas e as artes, e enfatizando a ligação entre música e movimento (MACBA, 2016hh); apresentação da coreografia Gold Dust Rush, em dezembro de 2016, por Eulàlia Bergadà, a qual alude ao delírio festivo e à febre mística, e que propõe uma viagem visual e sonora em torno do conceito de delírio (MACBA, 2016ii).

\section{O PEI}

Desde a crise institucional que, como vimos, atingiu o MACBA, em 2015, e a demissão de Valentín Roma e Paul B. Preciado, o PEI tivera suas atividades interrompidas, situação que se estendeu pelo ano de 2016. Desse modo, não houve, em 2016, a realização de atividades públicas pelos integrantes do Programa, como as edições do Seminário PEI Aberto. Já em 2017, o PEI volta à ativa para sua sexta edição, tendo sua equipe acadêmica sido renovada, e de modo a contar com a presença de Lucía Egaña, Marcelo Expósito, Marina Garcés, Dora García, Pablo Martínez, Emilio Santiago Muíño e Jaime Vindel. Desse modo, a partir de 2017, podemos observar o retorno das atividades públicas organizadas por alunos e professores do PEI, tais como (Ver Anexo J) os seminários Petróleo, Revolución e Aprender a Imaginarse. Sobre Pedagogías y Emancipación.

\section{Grupo de leitura}

Entre janeiro e junho de 2017, reuniu-se o grupo de leitura ;Encarna!, coordenado por Aimar Pérez Galí e Mar Medina, com o objetivo de organizar um espaço no qual a leitura seria entendida como encarnação ou incorporação, e de acordo com a ideia de que entender um texto a partir do corpo, assim como entender qualquer obra, seja escrita, visual, sonora ou experiencial, ofereceria a possibilidade de mudança e deslocamento. Assim, os encontros pretenderam reunir as condições que pudessem convidar os participantes a pensar de outra maneira, gerando diálogo e movimento, e tendo a pele como lugar de experiência dessa encarnação. As linhas conceituais que se quiseram encarnar se constituítam ao redor das “ações épicas” coletivas, anônimas e minoritárias. Buscou-se tratar de questões sobre cultura, 
negritude, adolescência, políticas do tato, todas elas silenciadas à margem nos marcos hegemônicos de validação e visibilidade (MACBA, 2017hh).

\section{Parlem de...}

Em fevereiro de 2017, tem início o programa Parlem de... que tem por objetivo gerar espaços de debate, a partir das exposições do Museu, entre distintos agentes e artistas da cidade e o público visitante. É definido como um espaço de encontro, que entende as exposições como poderosos dispositivos ativadores da imaginação e geradores de discursos que frequentemente excedem aqueles previstos pela instituição ou pré-concebidos pela equipe curatorial (MACBA, 2017ii). Durante o período analisado, o programa contou com sessões com os temas: Hablemos de Imágenes, Memoria y Decolonialidad, Los Ochenta e Parlem de... Brossa.

\section{Ciclos de Cinema}

Continuaram a ser realizadas, entre as atividades do MACBA, diversos ciclos de cinema, como Miro en el Espejo y me Veo, apresentaçãode filmes de artistas mulheres pioneiras na videoarte, provenientes da Coleção de Vídeo Data Bank (MACBA, 2017jj) e Alternate Endings, Radical Beginnings, programa de vídeo por meio do qual o MACBA participou da iniciativa A Day Without Art, no dia primeiro de dezembro de 2017, iniciada em 1989 pela organização Visual AIDS de Nueva York, a propósito do dia mundial de luta conta a AIDS. Nessa edição, foram priorizadas as narrativas negras na atual pandemia de AIDS, através de sete curtas videográficos realizados para a ocasião pelos artistas Mykki Blanco, Cheryl Dunye \& Ellen Spiro, Reina Gossett, Thomas Allen Harris, Kia Labeija, Tiona Nekkia McClodden e Brontez Purnell (MACBA, 2017kk).

\section{Publicações}

Até 2017, mantiveram-se, no MACBA, as linhas editoriais de publicação de catálogos acerca das exposições realizadas no Museu; livros vinculados à coleção; ensaios, entre eles o projeto de pesquisa para a publicação Desacuerdos, que teve sua última edição em 2014; Quaderns portàtils e Quaderns d'àudio. 


\section{Programas de Colaboração}

Entre 2016 e 2017, todos os projetos de colaborativos dos quais o MACBA vinha participando desde a gestão anterior tiveram continuidade, com exceção de MeLa, Museos europeos en una época de migraciones, que, conforme previsto, terminou em 2015.

\section{As Greves}

Em julho de 2016 e agosto de 2017, foram observadas greves de trabalhadores, tanto do MACBA, como de outras instituições culturais, que exigiam melhores condições de trabalho. Tais funcionários, responsáveis por prestar serviços ao público, como os de mediação e educação, eram subcontratados pelo Museu, por meio de empresas como a Ciut'art, e vinham enfrentando condições precarizadas de trabalho, sendo obrigados a firmar contratos de trabalho temporário ou sob o regime de "falsos" autônomos, fraude de lei que os fazia contribuir com a Segurança Social, sem que tivessem contrato laboral ou figurassem na folha de pagamento (RODRÍGUEZ, 2016). Tal questão, no entanto, não é exclusiva ao MACBA e vem sendo cada vez mais comum nos últimos tempos, inclusive em escala global. Para Marta Álvarez (2016), a raiz do problema advém de uma má com compreensão acerca da função e do funcionamento dos museus, de modo que a extensão do modelo empresarial de gestão próprio da indústria cultural levou-os à busca por rentabilidade, o que afetou de maneira fundamental os serviços de educação e mediação, resultando em situações de precariedade para muitos trabalhadores. Trata-se de um processo de desmantelamento dos museus públicos, e de empobrecimento de suas condições de trabalho, que vem se agravando desde 2003, quando empresas especializadas passaram a ser encarregadas desses serviços (RODRÍGUEZ, 2016). Nesse sentido, para Diana Guijarro (2016), não houve um controle a respeito da escolha das empresas às quais se atribuía as concessões, de modo que as instituições negligenciaram sua responsabilidade perante a situação. Para Laura Cano (2016), se os museus pretendem ser uma porta aberta à comunidade, às identidades e à reflexão sobre a realidade, não faz sentido que os primeiros aos quais dêem as costas sejam seus próprios funcionários. 


\subsubsection{A recepção da gestão Ferran Barenblit}

Em fevereiro de 2016, a reportagem No News en el MACBA, do jornal El Mundo, destaca a falta de novidades quando da apresentação da temporada de 2016 do Museu, herdada de Bartomeu Marí. Mesmo reconhecendo que Ferran Barenblit teve pouca margem de manobra para acrescentar novas mostras, a reportagem afirma que seu discurso permanece calcado ao de Marí, sendo que teria se limitado a programar a exposição Punk. Sus rastros en el arte contemporâneo, que teve grande êxito no CA2M de Móstoles (GRAELL, 2016).

\subsubsection{Sobre a gestão Ferran Barenblit}

No que tange a seu discurso, notamos que as propostas de Ferran Barenblit para o MACBA carregam elementos pertinentes às duas gestões anteriores, de modo que reconhece a instituição como dotada de discurso próprio e sólido, o qual não deveria ser alterado, mas sim ter continuidade ao longo de sua gestão. Assim, o diretor faz referência a elementos como a importância de o MACBA revisar a História da Arte sob uma perspectiva contrahegemônica, de modo a reescrever narrativas, proposta que se inicia na gestão de Manuel Borja-Villel e é continuada pela de Bartomeu Marí. Notamos, em Barenblit, a intenção de que o recorte temporal dessas narrativas avançasse, de modo a abordar, dessa vez, a década de noventa. Em 2016, tais premissas estão presentes em exposições como José Antonio Hernández-Díez. No Temeré Mal Alguno, em que foi questionado o domínio dos artistas europeus e norteamericanos no sistema da arte contemporânea e Gelatina Dura - Historias Escamoteadas de los 80, que pretendeu evidenciar histórias ignoradas pelos relatos oficiais do período entre 1977 e 1992, na Espanha, abordando a cultura underground dos anos setenta e oitenta. Em 2017, esse mesmo objetivo se vê presente em exposições como MUESTREO \#1, que buscou evidenciar conteúdos que habitualmente permanecem ocultos do público, como documentos e obras que se distanciam do sentido tradicional atrelado à lógica do mercado de arte e Rosemarie Castoro. Enfocar al Infinito, que procurou mostrar a obra da artista estadunidense, pouco conhecida em meio a um movimento considerado essencialmente masculino, o minimalista.

Barenblit também reconhece, assim como nas gestões anteriores, o potencial político do museu, de modo que, como vimos, entende a instituição como agente de questionamento e dúvida, e onde se deve contestar politicamente o mundo. Tal entendimento foi evidenciado na 
organização de diversas atividades, tais como a exposição dos trabalhos do coletivo Forensic Architecture, que buscou discutir temas relacionados a violações de direitos humanos; a exposição de trabalhos em vídeo da artista Martha Roesler, que levantou temas como como imigração, exploração laboral, a cumplicidade entre as corporações multinacionais, o governo dos Estados Unidos e os regimes ditatoriais da América Latina, bem como questões de gênero e a instrumentalização do corpo feminino; o encontro Procesos Constituyentes, que discutiu acerca das ameaças aos processos democráticos em países latino-americanos e das tensões políticas nos países europeus frente à rigidez imposta pelo euro às economias deficitárias; o curso Barcelona Wars: Del Imperio De Los Rentistas Al Contra Ataque Vecinal, que abordou a questão da influência da especulação sobre os custos de moradia em Barcelona, bem como buscou pensar ferramentas de contruibuição para a luta contra tal fenômeno; o encontro Poner a las Mujeres en el Centro para Pensar el Presente. Violencia, Comunidad y Estado en el Siglo XXI, que se propôs pensar o mundo desde a perspectiva das mulheres, seu posicionamento determinado nas sociedades e a forma como elas se veem afetadas pelas políticas públicas e de mercados.

Pudemos observar também uma continuidade, na nova gestão, no que tange à articulação entre as diversas atividades realizadas no Museu, de modo que importantes questões possam ser discutidas em diferentes espaços e formatos, sejam por meio de exposições, oficinas, debates, publicações, entre outros.

Ademais, notamos como continuaram a ser realizados programas de formação de professorado, oficinas e visitas com grupos escolares de todos os níveis, bem como grupos voltado a grupos espontâneos, algumas delas contando com a presença de artistas e curadores. Também o programa educativo Habitació 1418, voltado para grupo espontâneo adolescente, organizou interessantes atividades de trabalho colaborativo, de discussão de temas como feminismo e racismo, e de aproximação com o bairro de Raval, contando com a participação de coletivos de artistas.

Entre os aportes do novo diretor à programação do MACBA, está a intenção de dar mais destaque ao âmbito da performance e às culturas populares. Desse modo, no período observado, foram organizadas diversas intervenções e apresentações de performance no MACBA, tanto no espaço do prédio principal, como nos anexos da Capela e do Convento dels Àngels.

Vale notar a criação dos programas Museu Cerrado e Parlem de..., que têm o objetivo de promover aproximações entre o público do Museu e os agentes culturais, como artistas e 
curadores, de modo a gerar espaços de diálogos sobre seus trabalhos, bem como os temas levantados pelas exposições.

Quanto às atividades públicas organizadas pelo PEI, vimos como essas não foram realizadas em 2016, enquanto o programa passava por processo de reorganização, sendo que foram retomadas em 2017, mais uma vez trazendo importantes discussões, por meio dos seminários PEI Aberto, de temas, como vimos, ligados à política e economia em escala global, pedagogia e emancipação.

Destaca-se também, no discurso do novo diretor, a presença de elementos no que tange ao contexto em que operam as instituições culturais tanto na Espanha como globalmente, de modo que é ressaltada a espetacularização da cultura e a tentativa de sua cooptação como atração turística e de ativação econômica, elementos que devem ser combatidos a fim de garantir a existência do museu como espaço de ativação de subjetividades. Ainda, nota-se que Barenblit corrobora o entendimento de Borja-Villel acerca da necessidade constante de afirmação do museu como serviço público, dedicado à comunidade, sendo que ressalta também a importância do cultivo das relações como o Raval, e a necessidade de se estreitar os laços com essa comunidade.

Quanto à importância da atuação do Museu junto a movimentos sociais e a realização de processos colaborativos com a comunidade, nossa percepção, ao analisar a nova gestão foi similar àquela tida quanto à gestão de Bartomeu Marí: observou-se a realização de propostas que buscaram ampliar o repertório crítico dos participantes, estimulando o diálogo e a reflexão. No entanto, assim como na gestão de Bartomeu Marí, faz falta na atual gestão, até o momento analisado, o engajamento do MACBA com projetos exteriores à instituição, não tanto de natureza teórica, mas também prática, de maneira reativa às demandas da sociedade, de organizações e movimentos sociais. Também poderia ter havido um maior convite aos participantes na elaboração conjunta e colaborativa das atividades do Museu, o que diz respeito à possibilidade de os visitantes colocarem em prática sua capacidade política através da instituição, em um processo interativo. 


\section{CONCLUSÃo}

Aqui, tentamos delinear algumas respostas para as questões levantadas ao longo do trabalho. Sendo assim, nossa principal preocupação foi, diante do esgotamento de muitas das propostas institucionais experimentais realizadas entre o final dos anos noventa e início dos anos dois mil em diversas localidades, investigar acerca da possibilidade de estabelecimento de uma cultura institucional nesse sentido, a partir da observação das propostas realizadas nas gestões dos diferentes diretores do MACBA. A gestão de Borja-Villel, como vimos, foi tomada como referência pelo caráter experimental de suas propostas, que buscavam ser experimentos em uma "Nova Institucionalidade", e as quais foram realizadas contemporaneamente às das outras instituições citadas no terceiro capítulo do trabalho. Outra questão colocada, a partir da observação das gestões, foi quanto a se a promoção desse tipo de propostas nas instituições de arte estaria, em grande parte, alicerçada na figura de diretores específicos, capazes de sustentar suas escolhas diante de possíveis antagonismos ou se, por outro lado, os interesses de suas estruturas decisórias, que no MACBA estão representadas pela Generalidade, Prefeitura, Fundação MACBA e o Ministério da Cultura, acabariam por sobrepujar a vontade dos diretores, limitando sua autonomia.

Diante do estudo do caso do MACBA, pudemos observar como, desde sua fundação, houve conflitos quanto ao projeto de museu a ser seguido pela instituição, sendo que alguns membros do Consórcio visavam a construção de um museu orientado a consolidar uma identidade nacional baseada na cultura, enquanto outros desejavam que aquele representasse o cosmopolitismo da Barcelona moderna, projetada nos mercados globais. Também não havia consenso quanto ao direcionamento a ser seguido pela Coleção do Museu, sendo que Generalidade e Prefeitura, apoiados na figura de Daniel Giralt-Miracle, buscvam dar destaque aos artistas nacionais, enquanto a Fundação, junto a Jean Louis Froment, apostava em uma Coleção mais internacionalizada. Vimos como a persistência dessa indefinição e a dificuldade de se chegar a um acordo acabou por levar à renúnica dos dois primeiros diretores do MACBA, Giralt-Miracle e Miquel Molins. Assim, notou-se como, mesmo com a reforma do estatuto do Museu, em 1994, para dotar o diretor de autoridade executiva, essa figura continuou passível de ter sua autonomia limitada por membros do Consórcio.

Na gestão de Manuel Borja-Villel, observamos, enfim, a consolidação de um projeto para o MACBA, dotado de um programa com diretrizes bem estabelecidas e amparado em um discurso político consolidado. Em nosso entendimento, tratou-se de um programa preocupado 
em aproximar as propostas do Museu do contexto local, bem como de questões políticas urgentes no âmbito internacional, por meio do debate e da realização de atividades colaborativas. Há que se considerar as críticas de que, em alguns momentos, possa ter havido lacunas na comunicação das intenções do Museu com relação ao público. Ainda assim, de modo geral, consideramos como relevantes tais experimentações institucionais.

Após a saída de Borja-Villel, as linhas gerais fixadas durante a sua gestão foram mantidas nas de Bartomeu Marí, seu sucessor e, atualmente, na de Ferran Barenblit, de modo que esses diretores buscaram promover atualizações de suas propostas, mas nunca substituições por completo. Assim, se olharmos por esse viés, Borja-Villel conseguiu, em termos, estabelecer um projeto de museu a ser continuado por seus sucessores, assim como vinculá-lo a um discurso pautado no engajamento político. No entanto, percebemos que, na prática, o projeto de Borja-Villel não teria se realizado completamente nas gestões posteriores, até o momento analisado (vale ressaltar que Ferran Barenblit segue no cargo), já que a ideia de estender a participação do público e de movimentos sociais nos processos do Museu teria de certa forma se perdido, ficando os projetos colaborativos restritos a oficinas, e a atividade de coletivos muitas vezes encerradas no plano teórico. Há que se considerar a importante proposta de atualização das diretrizes do MACBA, durante a gestão de Marí, para adequar-se às necessidades mais atuais do público, encabeçada por Valentín Roma e Paul B. Preciado, em que se propunha hibridação e flexibilização das exposições das atividades públicas. No entanto, vimos como tal proposta foi abruptamente interrompida pela crise gerada em decorrência do episódio do cancelamento da exposição A Besta e o Soberano por Bartomeu Marí, que acabou por demitir Roma e Preciado. Quer tenha se tratado de um caso de censura por parte da Fundação MACBA, ou de um gesto de autocensura por parte do diretor, evidenciou-se como o jogo de interesses por parte de cada um dos membros do Consórcio se mantem constante e capaz de influenciar nas decisões dos diretores. Indaga-se, aqui, se a decisão de Marí pode ser entendida como uma falta de "pulso firme" por parte do diretor, diante da Fundação, para sustentar a realização da exposição, o que nos leva a acreditar, por um lado, que também a figura do diretor exerce um papel-chave na condução de uma instituição de arte. Há que se ponderar, no entanto, como as instituições constituem-se, como vimos, em espaços de negociação, de modo que várias forças participam da tomada de decisões. Sendo assim, entende-se que o diretor não terá suas vontades sempre atendidas, como pudemos observar quanto aos percalços enfrentados por Daniel Giralt-Miracle e Miquel Molins na tentativa de estabelecimento de um projeto para a Coleção e o Museu. Contudo, 
entendemos que o diretor deve posicionar-se sempre de modo a garantir o funcionamento da instituição como serviço público, tendo em vista, prioritariamente, os interesses e as necessidades de seus visitantes.

Outra questão levantada no decorrer do trabalho diz respeito à dúvida quanto à atratividade das propostas das instituições experimentais e sua palatabilidade junto ao público, de modo que existe o perigo de que essas soem complicadas e até mesmo elitistas, de modo que acabem por abarcar apenas o público afeito ao "universo artístico". Diante disso, verificase a necessidade de um esforço de comunicação por parte dessas instituições, na medida do possível, haja vista que muitas delas, principalmente as de pequeno porte, não possuem amplos recursos. Mesmo assim, é premente que essas instituições se mostrem abertas ao público geral, de modo a romper com a austeridade que esses espaços são capazes de inspirar.

Diante do exposto, teria havido, afinal, resultados positivos e significativos dessas experimentações institucionais? Em nosso entendimento, a resposta certamente é afirmativa, pois, mesmo que, em muitos casos, tais propostas não tenham prosperado, por motivos que vão de problemas com financiamento a conflitos políticos e discordâncias ideológicas, elas ainda ressoam em iniciativas de instituições na atualidade, que buscam a consolidação de espaços mais críticos, inclusivos e participativos, em detrimento daqueles guiados unicamente por uma lógica financeira. Também concordamos que algumas dessas propostas possam ser aplicadas a instituições de maior porte, consequentemente, conseguindo atingir um público mais numeroso. Há que se enfatizar ainda que não há aqui a intenção de vilanizar o envolvimento corporativo e da iniciativa privada no financiamento das instituições culturais, mesmo porque, como vimos, já não é concebível um financiamento majoritariamente público da cultura e, mesmo que houvesse, aquelas estariam, muitas vezes, sujeitas aos interesses políticos dos governantes. Desse modo, há que se reconhecer o âmbito das instituições como espaços inerentes de conflito. Justamente por isso, a liderança por parte dos diretores das instituições se faz tão necessária, a fim de que seja garantida a ativação dessas como espaços verdadeiramente públicos e a serviço da comunidade. 


\section{REFERÊNCIAS}

ALBERRO, Alexander. Institutions, Critique and Institutional Critique. In: ALBERRO, Alexander; STIMSON, Blake. Institutional Critique. An anthology of artists' writings. Cambridge: MIT PRESS, 2009.

ART WORKERS' COALITION. Statement of Demands. In: ALBERRO, Alexander; STIMSON, Blake. Institutional Critique. An anthology of artists' writings. Cambridge: MIT PRESS, 2009.

ARTE INFORMADO. Bartomeu Marí, director del MACBA, rectifica, reabre exposición y pone su cargo a disposición [online]. 20 de março de 2015. Disponível em:

$<$ http://www.arteinformado.com/magazine/n/bartomeu-mari-director-del-macba-rectificareabre-exposicion-y-pone-su-cargo-a-disposicion-4575> Acesso em 28/06/18.

ARTISCHOCK. Bartomeu Mari se retracta: decide abrir muestra polemica y pone a la orden su cargo [online]. Revista Artischock. 20 de março de 2015. Disponível em:

$<$ http://artishockrevista.com/2015/03/20/bartomeu-mari-se-retracta-decide-abrir-muestrapolemica-pone-la-orden-cargo/> Acesso em: 25/03/18.

ARTISHOCK. El argentino Ferran Barenblit, nuevo director del macba [online]. 24 de julho de 2015. Disponível em: < $\underline{\text { http://artishockrevista.com/2015/07/24/argentino-ferran-barenblit- }}$ nuevo-director-del-macba/> Acesso em 28/06/18.

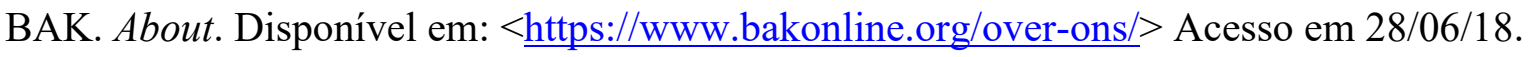

BAK. Long term projects. Disponível em: $<\underline{\text { https://www.bakonline.org/long-term-project/ }>}$ Acesso em 28/06/18.

BARENBLIT, Ferran (2015a). Ferran Barenblit: Al MACBA no se puede llegar com vovación de ruptura [online] ABC.ES, 30 de novembro de 2015. Disponível em:

$<$ http://www.abc.es/cultura/cultural/abci-ferran-barenblit-macba-no-puede-llegar-vocacionruptura-201511271814 noticia.html> Acesso em: 28/06/18

BARENBLIT, Ferran (2015b). Un museo es un actor político que no se posiciona en la política, sino que ayuda a reflexionar y cuestionarse sobre ella [online]. In: Revista Rambla. 10 de dezembro de 2015. Disponível em: $<$ https://www.revistarambla.com/un-museo-es-unactor-politico-que-no-se-posiciona-en-la-politica-sino-que-ayuda-a-reflexionar-ycuestionarse-sobre-ella/ $>$ Acesso em: 28/06/18

BATTCOCK, Gregory. Art Workers' Coalition Open Hearing Presentation. In: ALBERRO, Alexander; STIMSON, Blake. Institutional Critique. An anthology of artists' writings. Cambridge: MIT PRESS, 2009.

BELTING, Hans. Contemporary art as global art. A critical estimate. In: BELTING, H.; BUDDENSIEG, A. (Orgs.). The Global Art World: audiences, markets and museums. Ostfildern, 2009.

BENNETT, Tony. The Birth of the Museum. Nova York: Rouletge, 1995. 
BISHOP, Claire. O que é um curador? A ascensão (e queda?) do curador auteur. Concinnitas, ano 16, v. 02, n. 27, dezembro de 2015.

BISHOP, Claire. Radical Museology. Londres: Koening Books, 2013.

BORJA-VILLEL, M.B. MACBA ¿Cómo empodera um museo a la sociedad? In: Conversación com Manuel Borja-Villel. Madrid: Turpial, 2015.

BORJA-VILLEL, M.B. Editorial. Carta, Madrid: Museo Reina Sofia, 2 ed., abr. de 2011.

BORJA-VILLEL. M.B. ¿Son livres los museos? [online]. El cultural. 15 de maio de 2015. Disponível em: $<$ http://www.elcultural.com/revista/arte/Son-libres-los-museos/36469> Acesso em: 25/03/18.

BORJA-VILLEL, M.B. Museo, Memoria y Identidad. In: Colección MACBA. Museu de Arte Contemporânea de Barcelona, Barcelona, 2002.

BORJA VILLEL, M. J., M. CABAÑAS, K; RIBALTA, J., Objetos relacionales. Colección MACBA 2002-2007, Barcelona: MACBA, 2009.

BOSCO, Roberta. Ferran Barenblit, nuevo diretor del MACBA [online]. El País, 24 de julho de 2015. Disponível em:

https://elpais.com/ccaa/2015/07/23/catalunya/1437688216_712349.html. Acesso em

20/06/18.

BROODTHAERS, Marcel. A Conversation with Freddy de Vree. In: ALBERRO, Alexander; STIMSON, Blake. Institutional Critique. An anthology of artists' writings. Cambridge: MIT PRESS, 2009.

BRU DE SALA. MACBA, final de trajecte. El Periódico, Barcelona. 25 de março de 2015. Disponível em: https:/www.elperiodico.cat/ca/opinio/20150323/macba-final-de-trajecte4042759. Acesso em 03/11/18.

BUREN, Daniel. The function of the museum. In: ALBERRO, Alexander; STIMSON, Blake. Institutional Critique. An anthology of artists' writings. Cambridge: MIT PRESS, 2009.

CCS BARD. Personal protocols and other preferences: an exhibition with works by Michael Beutler, Esra Ersen, and Kirstine Roepstorff. CCS Bard Galleries. 2008. Disponível em: < https://www.bard.edu/ccs/exhibitions/personal-protocols-and-other-preferences-an-exhibitionwith-works-by-michael-beutler-esra-ersen-and-kirstine-roepstorff/> Acesso em 22/08/18.

CHERIX, Christophe. In \& Out of Amsterdam: Travels in Conceptual Art, 1960-1976. Nova York: The Museum of Modern Art, 2009.

DABUL, Lígia. Museus de grandes novidades: centros culturais e seu público. Horizontes Antropológicos, Porto Alegre, ano 14, n. 29, pp. 257-278, jan./jun. 2008.

DANTO, Arthur. Após o fim da arte: a arte contemporânea e os limites da História. São Paulo: Odysseus Editora, 2010. 
DESACUERDOS. Sobre arte, políticas y esferas públicas en el Estado español. In: Desacuerdos 1. MACBA / Arteleku UNIA arte y pensamiento, n. 1, 2004.

DOHERTY, Claire. The institution is dead! Long live the institution! Contemporary art and NewInstitutionalism. In: Engage: Art of Encounter, 15 ed., 2004, pp. 6-13.

EKEBERG, Jonas. Institutional Experiments Between Aesthetics and Activism. In: KERBERT, S.; KARLSEN, A. S (Orgs.). Self-organised. Londres: Open Editions, 2013.

EKEBERG, Jonas. Introduction: In: Verksted \#1: new institutionalism. Oslo: Office for contemporary art norway and authors, 2003.

EL DIARIO. Todos contra el director del Macba [online]. 23 de março de 2015. Disponível em: $<$ https://www.eldiario.es/cultura/arte/Macba_0_368513734.html $>$. Acesso em: 25/03/18.

EL PAIS. El Banco Mundial cancela su reunión de Barcelona para evitar las protestas [online]. Disponível em:

$<$ http://elpais.com/diario/2001/05/20/economia/990309604_850215.html $>$ Acesso em: 27/05/17.

EL PAIS. El MACBA inicia su expansión [online]. Disponível em: $<$ https://elpais.com/diario/2003/07/23/catalunya/1058922452 850215.html $>$ Acesso em 19/09/17.

ESCHE, Charles. The Possibility of Politics [online]. Entrevista para Jon-Ove Steihaug e Jonas Ekeberg. Kunstkritikk. 18 out. 2011. Disponível em: < http://www.kunstkritikk.no/artikler/the-possibility-of-politics/> Acesso em: 27/05/17.

ESCHE. Charles. “We were learning by doing”. Entrevistado por Lucie Kolb \& Gabriel Flückiger. In: (New) Institutional (ism). On Curating. Dezembro de 2013, n. 21, pp. 23-27.

ESCHE, Charles. What's the point of art centres anyway? - Possibility, art and democratic deviance [online]. EIPCP Multilingual Webjournal. Abril de 2004. Disponível em: $<$ http://republicart.net/disc/institution/esche01_en.htm> Acesso em: 15/05/2017.

EUROPAPRESS. Ferran Barenblitt: el MACBA de 2035 mirará la actualidad [online]. 7 de janeiro de 2017. Disponível em: $<\mathrm{http}$ ://www.europapress.es/catalunya/noticia-ferranbarenblit-macba-2035-mirara-actualidad-20170107112319.html $>$ Acesso em 28/06/18.

EUROPAPRESS. Ferran Barenblit, nuevo director del Macba: "Autonomía, toda; censura, ninguna", 8 de outubro de 2015. Disponível em:

$<\underline{\text { http://www.europapress.es/catalunya/noticia-ferran-barenblit-nuevo-director-macba- }}$ autonomia-toda-censura-ninguna-20151008073029.html > Acesso em 28/06/18.

EXPOSITO, Marcelo. MACBA ¿Cómo empodera um museo a la sociedad? In: Conversación com Manuel Borja-Villel. Madrid: Turpial, 2015.

FARQUHARSON, Alex. Bureaux de change [online]. Frieze, 02 de setembro de 2006.

Disponível em: $<$ https://frieze.com/article/bureaux-de-change> Acesso em 12/06/18. 
FERNANDEZ, I. M. G. El papel de los museos en la sociedade actual: discurso institucional o museo participativo. Complutum, 2015, Vol. 26 (2), pp. 39-47.

FRASER, Andrea. From the Critique of Institutions to an Institution of Critique. Artforum. Setembro de 2005, XLIV, n. 1, pp. 278-283.

FOSTER, Hal. Museus sem fim [online]. Revista Piauí, ed. 105, junho de 2015. Disponível em: < http://piaui.folha.uol.com.br/materia/museus-sem-fim/> Acesso em 28/05/17.

FOWLE, Kate. Who Cares? Understanding the Role of the Curator Today. In: Rand, S. e Kouris, H. (ed.) Cautionary Tales: Critical Curating. London: Apexart. 2007.

FRISACH, Montse. El MACBA fa um "reset”. El Punt Avui. 13 de fevereiro de 2014.

GARCÍA, Ángeles. La coproducción y el trueque garantizan las grandes exposiciones [online]. 5 de abril de 2012. Disponível em:

$<$ https://elpais.com/cultura/2012/04/05/actualidad/1333648004 659609.html $>$ Acesso em: 29/06/18.

GARRIDO, Cristina. El MACBA: ¿un debate público o privado? Diari de Tarragona. 26 de outubro de 2013.

GIRALT-MIRACLE, Daniel. Gestació i creació d'un projecte: el MACBA. Un somni que va costar de fer realitat: un museu per a l'art contemporani. In: BASSEGODA, Bonaventura. (Org). Col·leccionistes, col·leccions i museus: episodis de la història del patrimoni artístic de Catalunya. Barcelona: Publicacions i Edicions de la Universitat de Barcelona, 2007.

GRAELL, Vanessa. No news en el MACBA [online]. El Mundo, 08 de fevereiro de 2016. Disponível em:

$<$ http://www.elmundo.es/cataluna/2016/02/08/56b8e766e2704e9c658b4670.html $>$ Acesso em 29/06/18.

GUERRILLA ART ACTION GROUP. Communique. In: ALBERRO, Alexander; STIMSON, Blake. Institutional Critique. An anthology of artists' writings. Cambridge: MIT PRESS, 2009.

GROUPE RECHERCHE D'ART VISUEL. Manifestos. In: STILES, Kristine; SELZ, Peter. Theories and documents of contemporary art. A sourcebook of artists'writings. Los Angeles e Berkeley: University of California Press, 1996.

GROUPE RECHERCHE D'ART VISUEL. New Commitment. In: ALBERRO, Alexander; STIMSON, Blake. Institutional Critique. An anthology of artists' writings. Cambridge: MIT PRESS, 2009.

HAACKE, Hans. The Constituency. In: ALBERRO, Alexander; STIMSON, Blake. Institutional Critique. An anthology of artists' writings. Cambridge: MIT PRESS, 2009.

HEINICH, N., POLLAK, M. From Museum Curator to Exhibition Auteur: Inventing a singular position. In GREENBERG, R., FERGUSON B., NAIRNE S. (Orgs.), Thinking about exhibitions, Londres: Routledge, 2006. 
HLAVAJOVA, Maria. Institutional Criticality: Maria Hlavajova interviewed by Franciska Zólyom [online]. Entrevista com Franciska Zólyom. Tranzit. 09 de fevereiro de 2015.

Disponível em: $<$ http://tranzit.org/freeschool/interju/institutional-criticality-maria-hlavajovainterviewed-by-franciska-zolyom/?lang=en $>$ Acesso em 20/06/18.

HOLMES, Brian. Investigações extradisciplinares - Para uma nova crítica das instituições. Revista Concinnitas, Rio de Janeiro, v.1, n. 12, pp. 6-13, jul. 2008.

HOOPER-GREENHILL, Eilean. Interpretive Communities, Strategies and Repertoires. In: WATSON, Sheila (Org.). Museums and their Communities. Nova Iorque: Routledge, 2007.

JAREMTCHUK, Dária. MAC do Zanini: o museu crítico do museu. In: OLIVEIRA, E. D.; COUTO, M. F. M. (org.). Instituições da arte. Porto Alegre, Zouk, 2012.

KOLB, L.; FLUCKIGER, G. New Institutionalism Revisited. In: On Curating. Ed. 21, dezembro de 2013.

KRAUSS, Rosalind. The Cultural Logic of the Late Capitalist Museum. October, v. 54 (Outono, 1990), pp. 3-17.

KUNSTASPEKTE. Vi: Intentional Communities [online]. Disponível em: $<\underline{\mathrm{http}}: / /$ kunstaspekte.art/event/vi-intentional-communities-2001-05?hl=en $>$. Acesso em 20/06/18.

KUNSTKRITIKK. The possibility of politics [online]. Disponível em: $<$ http://www.kunstkritikk.no/artikler/the-possibility-of-politics/>. Acesso em 20/06/18.

LA RAZÓN. El MACBA recupera las exposiciones de tesis em sua nueva temporada. 17 de julho de 2009. Disponível em: $<$ https://www.larazon.es/historico/el-macba-recupera-lasexposiciones-de-tesis-en-su-nueva-temporada-ULLA_RAZON_166661> Acesso em 29/06/18.

LA VANGUARDIA. El Macba recupera su Programa de Estudios Independientes con el "espíritu inicial" [online]. 27 de março de 2017. Disponível em:

$<$ http://www.lavanguardia.com/vida/20170327/421235488466/el-macba-recupera-suprograma-de-estudios-independientes-con-el-espiritu-inicial.html> Acesso em 29/06/18.

LIND, Maria. Going Beyond Display - The Munich Kunstverein Years. Maria Lind In An Interview With Paul O'Neill. Entrevistada por Paul O'Neill. In: On Curating: Curating Critique, n. 9, 2011.

LIND, Maria. The Curatorial. In: Artforum, vol. 4, n. 2, outubro de 2009.

LIND, Maria. "We want to become an institution". An interview with Maria Lind. In: On Curating: (New) Institution (alism), n. 21, dezembro de 2013.

MACBA. ;Basta de sexismo! 2016aa. Disponível em: https://www.macba.cat/es/basta-desexismo. Acesso em: 17/08/18. 
MACBA. ;Bienvenidas!. 2016y. Disponível em: https://www.macba.cat/en/habitacio-1418bienvenidas. Acesso em: 17/08/18.

MACBA. ;Encarna! 2017hh. Disponível em: https://www.macba.cat/es/encarna-grupo-delectura. Acesso em: 17/08/18.

MACBA. 365 dias de trabajo invisible. Disponível em: https:/www.macba.cat/es/365-diasde-trabajo-invisible- .Acesso em: 17/08/18.

MACBA. Acerca de los Programas educativos. Site MACBA. Disponível em: $<$ https://www.macba.cat/es/acerca-de-los-programas-educativos/1/actividadesanteriores/activ $>$ Acesso em: 25/03/18.

MACBA. Actividades John Baldessari Pura Belleza. 2010g. Disponível em: https://www.macba.cat/es/john-baldessari-pura-belleza-3. Acesso em: 20/10/18.

MACBA. Agnès Pe. 2016gg. Disponível em: https://www.macba.cat/en/experience-macba-agnespe. Acesso em: 20/10/18.

MACBA. Akram Zaatari. 2017b. Disponível em https://www.macba.cat/es/deo-historiaanotada-de-larab-foundation--akram-zaatari Acesso em: 17/08/18.

MACBA. Aleksandr Sokurov en la Colección MACBA. 2012g. Disponível em: < https://www.macba.cat/es/expo-military-series > Acesso em 18/08/18.

MACBA. Alternate endings, radical beginnings. 2017kk. Disponível em: https://www.macba.cat/en/alternate-endings-radical-beginnings. Acesso em 18/08/18.

MACBA. Análisis Participativo del Espacio Urbano del Barrio del Raval. 2014. Disponível em: $<$ https://www.macba.cat/es/analisis-participativo-del-raval $>$ Acesso em 12/06/18.

MACBA. Andrea Fraser. L'1\%, C'EST MOI. 2016D. Disponível em: https://www.macba.cat/en/exhibition-andrea-fraser Acesso em: 17/08/18.

MACBA. Antagonismos. 2001. Disponível em: $<$ https://www.macba.cat/es/expoantagonismos/1/exposiciones-anteriores/expo> Acesso em 20/08/18.

MACBA. Apertura de puertas. 1995. Disponível em: $<$ https://www.macba.cat/es/expoapertura-de-puertas/1/exposiciones-anteriores/expo Acesso em 20/08/18.

MACBA. Archivo Universal. La condición del documento y la utopía fotográfica moderna. 2008. Disponível em: $<$ https://www.macba.cat/es/archivo-universal-la-condicion-deldocumento-y-la-utopia-fotografica-moderna-1> Acesso em 12/06/18.

MACBA. Arte contemporáneo. Nível cero. 2012. Disponível em: $<$ https://www.macba.cat/es/arte-contemporaneo-nivel-cero $>$ Acesso em 12/06/18.

MACBA. Arte, dos puntos - Barcelona Vive el Arte Contemporáneo. 2013e. Disponível em:

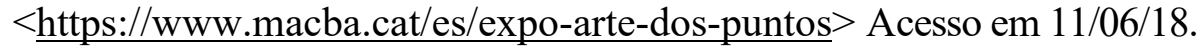


MACBA. Arte, museos y escuela. 2016. Disponível em:

https://www.macba.cat/es/profesorado-arte-museos-y-escuela Acesso em: 17/08/18.

MACBA. Arte y acción. 1999. Disponível em: $<$ https://www.macba.cat/es/expo-arte-yaccion/1/exposiciones-anteriores/expo $>$ Acesso em 20/08/18.

MACBA. Arquitectura. s.d. DisponÍvel em: $<$ https://www.macba.cat/es/arquitectura $>$ Acesso em 20/08/18.

MACBA. Arquitectura forense. 2017. Disponível em: https:/www.macba.cat/es/arquitecturaforense-seminario. Acesso em: 17/08/18.

MACBA. Aquí se acaba la visita. 2017r. Disponível em: https://www.macba.cat/es/aquiacaba-la-visita. Acesso em: 17/08/18.

MACBA. Audición de Poesía Sonora. 2010e. Disponível em:

$<$ https://www.macba.cat/es/audicion-de-poesia-sonora-de-gil-j-wolman $>$ Acesso em 12/06/18.

MACBA. Autoedición, Anarchivo, Fotozines. 2016s. Disponível em:

https://www.macba.cat/es/autoedicion-anarchivo-fotozines. Acesso em 12/06/18.

MACBA. Baldessari visto por... 2010. Disponível em: $<\underline{\text { https://www.macba.cat/es/baldessari- }}$ visto-por-/1/actividades-anteriores/www.calcego.com> Acesso em 12/06/18.

MACBA. Barcelona (des)colonial. Posesiones de Ultramar y Cambio Urbano (1835-1898). 2014. Disponível em: < https://www.macba.cat/es/barcelona--descolonial > Acesso em: $17 / 08 / 18$

MACBA. Barcelona Wars. 2016i. Disponível em: https://www.macba.cat/es/barcelona-warsdel-imperio-de-los-rentistas-al-contraataque-vecinal. Acesso em: 17/08/18.

MACBA. Before the Name. 2016cc. Disponível em: https:/www.macba.cat/en/before-thename-francesca-banchelli. Acesso em: 17/08/18.

MACBA. Benet Rossell, detrás y delante de la câmera. 2010j. Disponível em: https:/www.macba.cat/es/benet-rossell-detras-y-delante-de-la-camara. Acesso em: 17/08/18.

MACBA. Blind Dates em Arena, de Rita McBride. 2012o. Disponível em: https://www.macba.cat/es/conferencia-blind-date-en-arena. Acesso em 20/08/18.

MACBA. Box Sized DIE. 2016n. Disponível em: https://www.macba.cat/es/box-sized-diefeaturing-caustic. Acesso em 20/08/18.

MACBA. Cabaret. 2017gg. Disponível em: https://www.macba.cat/es/cabaret. Acesso em 20/08/18.

MACBA. Campo de fuerzas. 2000. Disponível em: $<$ https://www.macba.cat/es/expo-camposde-fuerzas/1/exposiciones-anteriores/expo $>$ Acesso em 20/08/18. 
MACBA. Casas im-proprias.2001. Disponível em: $<$ https://www.macba.cat/es/expo-casasim-propias/1/exposiciones-anteriores/expo > Acesso em 20/08/18.

MACBA. Cildo Meireles. 2009c. Disponível em: $<$ https://www.macba.cat/en/exhibition-cildo-

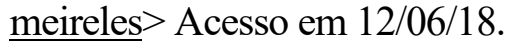

MACBA. Colección MACBA. 2010a. Disponível em: < https:/www.macba.cat/es/expo-coleccion$\underline{\text { macba-23 }}>$ Acesso em 11/06/18.

MACBA. Con la comida também se juega. 2016m. Disponível em: https:/www.macba.cat/es/conla-comida-tambien-se-juega-2017. Acesso em 11/06/18.

MACBA. Conceptualismos del Sur. 2012. Disponível em:

$<$ https://www.macba.cat/es/seminario-tropicamp $>$ Acesso em 11/06/18.

MACBA. Conferência Abigail Solomon-Godeau. 2011g. Disponível em:

https://www.macba.cat/es/conferencia-a-carrec-dabigail-solomon-godeau. Acesso em 12/06/18.

MACBA. Conferência Otolith Group. 2011f. Disponível em: https://www.macba.cat/es/anjalikasagar-y-kodwo-eshun-the-otolith-group-conversan-con-chus-martinez. Acesso em 12/06/18.

MACBA. Conferências Estais listos para la Televisión?. 2010i. Disponível em: https://www.macba.cat/es/estais-listos-para. Acesso em 12/06/18.

MACBA. Conferencia y conversación com Martha Rosler. 2017q. Disponível em: https://www.macba.cat/es/conferencia-conversacion-con-martha-rosler. Acesso em 12/06/18.

MACBA. Conocimiento Contra el Capitalismo Financiero. 2011a. Disponível em: $<$ https://www.macba.cat/es/kafca-conocimiento-contra-el-capitalismo-financiero $>$ Acesso em $12 / 06 / 18$.

MACBA. Conversación entre Akram Zaatari y Hiuwai Chu. 2017k. Disponível em: https://www.macba.cat/es/akram-zaatari-hiuwai-chu-conversacion. Acesso em 12/06/18.

MACBA. Conversación entre Andrea Fraser y Cuauhtémoc Media. 2016j. Disponível em: https://www.macba.cat/es/conversacion-entre-andrea-fraser-y-cuauhtemoc-medina. Acesso em $12 / 06 / 18$.

MACBA. Conversación entre Rita McBride y Bartomeu Marí. 20121. Disponível em: https://www.macba.cat/ca/conversa-rita-mcbride-bartomeu-mari. Acesso em 12/06/18.

MACBA. Conversación sobre la exposición Filtraciones. 2012n. Disponível em: https://www.macba.cat/es/conversacion-nasrin-tabatabai-y-babak-afrassiabi. Acesso em 12/06/18.

MACBA. COSMOBILIS. 2017W. Disponível em: https://www.macba.cat/en/cosmobilis. Acesso em 12/06/18.

MACBA. Crisis global: teoria urbana crítica. 2017g. Disponível em https://www.macba.cat/es/crisis-global-teoria-urbana-critica Acesso em: 17/08/18. 
MACBA. Cuestiones de espacio. 2010d. Disponível em:

https://www.macba.cat/es/cuestiones-de-espacio. Acesso em 20/10/18.

MACBA. Del Monumento al Nonumento. 2014. Disponível em: < https://www.macba.cat/es/nonumento $>$ Acesso em 11/06/18.

MACBA. De Museo en Museo. Vacaciones de Verano en la Ciudad. 2011. Disponível em: $<$ https://www.macba.cat/es/de-museo-en-museo-vacaciones-de-verano-en-la-ciudad $>$ Acesso em $12 / 06 / 18$.

MACBA. De Paso. 2011h. Disponível em: https://www.macba.cat/en/exhibition-natascha-sadr. Acesso em 12/06/18.

MACBA. Descentrados. Otros relatos del conceptualismo (argentino y latinoamericano). 2006. Disponível em: $<\underline{\text { https://www.macba.cat/es/descentrados-otros-relatos-del- }}$ conceptualismo-argentino-y-latinoamericano $>$ Acesso em: 11/06/18.

MACBA. Descolonizar el Museo. 2014. Disponível em: $<$ https://www.macba.cat/es/descolonizar-museo $>$ Acesso em 11/06/18.

MACBA. Después del Neoliberalismo: Ciudades y Caos Sistémico. 2008a. Disponível em: < https://www.macba.cat/es/despues-del-neoliberalismo--ciudades-y-caos-sistemico $>$ Acesso em 11/06/18.

MACBA. Devenir documento de arte: Archivo, Desclasificasión y Derechos Humanos. 2014c. Disponível em: $<$ https://www.macba.cat/es/devenir-documento-de-arte> Acesso em $22 / 08 / 18$.

MACBA. Ebb \& Flow. A onda traz. O vento leva. 2012r. Disponível em: < https://www.macba.cat/en/exhibition-capella-gabriel-mascaro> Acesso em 22/08/18.

MACBA. Economía y ecología política del turismo. 2017h. Disponível em https://www.macba.cat/es/economia-y-ecologia-politica-del-turismo Acesso em: 17/08/18.

MACBA. Edición Agotada. 2002. Disponível em: $<$ https://www.macba.cat/es/expo-edicionagotada/1/exposiciones-anteriores/expo $>$ Acesso em 20/08/18.

MACBA. El arte tras los femenismos. 2008c. Disponível em: $<\underline{\text { https://www.macba.cat/es/el- }}$ arte-tras-los-feminismos-hacia-una-historiografia-postfeminista-del-arte-contemporaneo $>$ Acesso em 11/06/18.

MACBA. El Ballroom tiene algo que decir sobre el ser humano y la lucha por la libertad. 2013c. Disponível em: < https://www.macba.cat/es/ballroom-mor $>$ Acesso em 11/06/18.

MACBA. El Descontento y la Promesa. Colonialidad. Modernidad y Epistemologías Descoloniales. 2014. Disponível em: < https://www.macba.cat/es/pei-abierto-el-descontentoy-la-promesa> Acesso em 11/06/18.

MACBA. El espacio desbordado. Otras maneras de visitar una exposición: Visitas a la exposición Dorothee y Konrad Fischer. Archivos de una actitud. 2010c. Disponível em: 
$<$ https://www.macba.cat/es/el-espacio-desbordado-otras-maneras-de-visitar-una-exposicion $>$ Acesso em 12/06/18.

MACBA. El Descontento y la Promesa. Colonialidad. Modernidad y Epistemologías Descoloniales. 2014. Disponível em: $<$ https://www.macba.cat/es/pei-abierto-el-descontentoy-la-promesa/1/actividades $>$ Acesso em 11/06/18.

MACBA. El museu pren forma. Memòria d'activitats 1995-1996. Museu de Arte Contemporânea de Barcelona, Barcelona, 1996.

MACBA. El Pesanervios. 2016q. Disponível em: https://www.macba.cat/es/el-pesanerviosjoan-morey. Acesso em 11/06/18.

MACBA. El Raval Siempre Estuvo Aquí. 2016u. Disponível em:

https://www.macba.cat/es/hab-1418-el-raval-siempre-estuvo-aqui. Acesso em 11/06/18.

MACBA. El Raval: Sonido, Tiempo y Espiar. 2016x. Disponível em:

https://www.macba.cat/es/el-raval-sonido-tiempo-espiar. Acesso em 11/06/18.

MACBA. El relanzamiento de la crítica. 2003. Disponível em: <

https://www.macba.cat/es/el-relanzamiento-de-la-critica> Acesso em: 11/06/18.

MACBA. El toque Spero. 2008h. Disponível em: https://www.macba.cat/es/el-toque-spero. Acesso em $11 / 06 / 18$.

MACBA. En el Laberinto - Àngels Ribé 1969-1984. 2011e. Disponível em:

$<$ https://www.macba.cat/es/expo-en-el-laberinto $>$ Acesso em 12/06/18.

MACBA. Encarnar la Crítica Institucional. 2016o. Disponível em:

https://www.macba.cat/es/seminario-encarnar-la-critica-institucional. Acesso em 12/06/18.

MACBA. Encuentro com Raquel Gutierrez. 2017. Disponível em

https://www.macba.cat/es/encuentro-con-raquel-gutierrez Acesso em: 17/08/18.

MACBA. Encuentro con Silvia Federici. 2012b. Disponível em:

$<$ https://www.macba.cat/es/conversacion-silvia-federici> Acesso em 11/06/18.

MACBA. Encuentro entre Muntadas, Anne Benichou y Bartomeu Marí. 2012k.

https://www.macba.cat/es/conversacion-muntadas-benichou-bartomeu. Acesso em 11/06/18.

MACBA. Episodios Críticos (1957-2011). Colección MACBA. 2012d. Disponível em: < https://www.macba.cat/es/expo-episodios-criticos> Acesso em 11/06/18.

MACBA. Escrito en el viento. Ciclo de cine. 2013h. Disponível em:

https://www.macba.cat/es/lawrence-weiner-escrit-en-el-vent. Acesso em 11/06/18.

MACBA. Espacio de lectura: Brasil. 2009i. Disponível em: https:/www.macba.cat/es/expoespacio-de-lectura-brasil. Acesso em 11/06/18. 
MACBA. Estética Investigativa, Acontecimento y Huella. 2017p. Disponível em: https://www.macba.cat/es/arquitectura-forense-seminario. Acesso em 11/06/18.

MACBA. Estetica y política. Um vínculo para replantear. 2002. Disponível em: < https://www.macba.cat/es/estetica-y-politica-un-vinculo-para-replantear $>$ Acesso em: $11 / 06 / 18$.

MACBA. Estáis listos para la televisión? 2010f. Disponível em: https://www.macba.cat/es/estais-listos-para-la-television-1. Acesso em: 11/06/18.

MACBA. Evidencia, Activismo y Ley en la Era de la Posverdad. 2017o. Disponível em: https://www.macba.cat/es/evidencia-activismo-y-ley-en-la-era-de-la-posverdad. Acesso em: $11 / 06 / 18$.

MACBA. Expressart. Museo Portátil. 2015. Disponível em: < https://www.macba.cat/expressart-museo-portatil-2014> Acesso em 12/06/18.

MACBA. Face the Strange Party. 2017v. Disponível em: https://www.macba.cat/ca/face-thestrange-party. Acesso em 12/06/18.

MACBA. Fanzines con Doza Electrónica. 2017y. Disponível em: https://www.macba.cat/en/fanzines-con-doza-electronica. Acesso em: 17/08/18.

MACBA. Focusing on the learner. 2016p. Disponível em:

https://www.macba.cat/es/focusing-on-the-learner. Acesso em: 17/08/18.

MACBA. Forensic Architecture. 2017e. Disponível em:

https://www.macba.cat/en/exhibition-forensic-architecture. Acesso em 20/08/18.

MACBA. Fragmentos. 1996. Disponível em: $<$ https://www.macba.cat/es/expo-fragmentos $>$ Acesso em 20/08/18.

MACBA. Francesc Torres. Da Capo. 2008f. Disponível em: $<$ https://www.macba.cat/en/expofrancesc-torres $>$ Acesso em 12/06/18.

MACBA. Gelatina dura. Historias escamoteadas de los 80. 2016f. Disponível em: https://www.macba.cat/es/expo-los-ochenta 2016. Acesso em: 17/08/18.

MACBA. Gold Dust Rush. 2016ii. Disponível em: https://www.macba.cat/es/eulalia-bergadagold-dust-rush. Acesso em: 17/08/18.

MACBA. GRAFI_SISMOS. 2016Z. Disponível em: https://www.macba.cat/en/grafi_sismos. Acesso em: 17/08/18.

MACBA. Grup de Treball. 1999. Disponível em: $<$ https://www.macba.cat/es/expo-grup-detreball/1/exposiciones-anteriores/expo $>$ Acesso em 20/08/18.

MACBA. Grupo de lectura: Barcelona del modelo a la marca. 2012o. Disponível em: $<$ https://www.macba.cat/es/grupo-de-lectura-barcelona-del-modelo-a-la-marca $>$ Acesso em $22 / 08 / 18$. 
MACBA. Grupo de lectura: del Chino al Raval. 2013i. Disponível em:<

https://www.macba.cat/es/grupo-lectura-del-chino-al-raval> Acesso em 22/08/18.

MACBA. Hibridaciones. Arte y Arquitectura. 2014. Disponível em:

$<$ https://www.macba.cat/es/hibridaciones--arte-y-arquitectura-2014 > Acesso em 12/06/18.

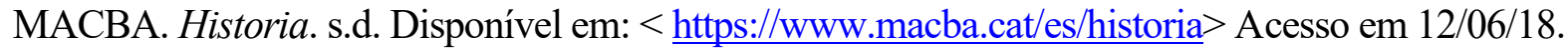

MACBA. Historias Secretas de un Habitáculo. 2016r. Disponível em:

https://www.macba.cat/en/historias-secretas-habitaculo. Acesso em 12/06/18.

MACBA. ¡Hula! Juego, Performance y Acció. 2015a. Disponível em: <

https://www.macba.cat/es/hula-juego-performance-y-accion> Acesso em 20/10/18.

MACBA. Idiorritimias. 2016dd. Disponível em: https://www.macba.cat/es/idiorritmias.

Acesso em 20/10/18.

MACBA. Imagen Cinematográfica, Color e Improvisación. 2016bb. Disponível em: https://www.macba.cat/es/imagen-color-improvisacion-cinematografica-loop-2016. Acesso em 20/10/18.

MACBA. Imaginarios postcoloniales de África. 2013b. Disponível em:

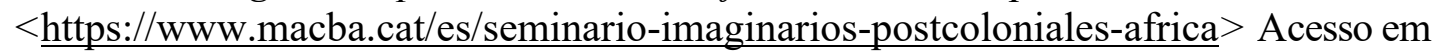

$11 / 06 / 18$.

MACBA. Intervenciones en la Historia Anotada de la Arab Image Foundation. 2017ee.

Disponível em: https:/www.macba.cat/es/visita-comentada-historia-anotada-arab-imagefoundation. Acesso em 11/06/18.

MACBA. In the same boat. 2016. Disponível em: https:/www.macba.cat/en/in-the-same-boat Acesso em: 17/08/18.

MACBA. Interferencias sonoras. 2017s. Disponível em:

https://www.macba.cat/en/interferencias-sonoras. Acesso em: 17/08/18.

MACBA. Joan Rabascall. Producción 1964-1982. 2009. Disponível em:

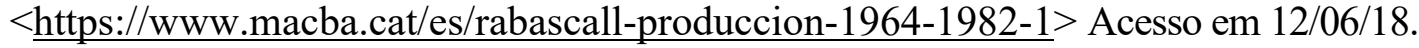

MACBA. John Baldessari. Pura Belleza. 2010b. Disponível em: https://www.macba.cat/es/expojohn-baldessari. Acesso em: 20/10/18.

MACBA. Jornadas sobre visualidades críticas. 2017. Disponível em:

https://www.macba.cat/es/jornadas-sobre-visualidades-criticas Acesso em: 17/08/18.

MACBA. José Antonio Hernandez Diez. 2016b. Disponível

em: $<$ https://www.macba.cat/es/expo-jose-a-hernandez-diez $>$ Acesso em: 17/08/18.

MACBA. La anarquía del silencio. John Cage y el arte experimental. Actividades. 2009h. Disponível em:< https://www.macba.cat/es/otonyo-cage-cunningham> Acesso em: 17/08/18. 
MACBA. La condición del museo y el destino de la crítica institucional. 2006. Disponível em: $<$ https://www.macba.cat/es/la-condicion-del-museo-y-el-destino-de-la-criticainstitucional $>$ Acesso em: 11/06/18.

MACBA. La pesadilla que no acaba nunca. 2017. Disponível em https:/www.macba.cat/es/la-pesadilla-que-no-acaba-nunca-marina-garces-christian-laval Acesso em: 17/08/18.

MACBA. La revolución jurídica de los bienes comunes. 2017j. Disponível em https:/www.macba.cat/es/la-revolucion-juridica-de-los-bienes-comunes Acesso em: $17 / 08 / 18$

MACBA. La construcción del público. 2003. Disponível em: < https://www.macba.cat/es/laconstruccion-del-publico> Acesso em: 11/06/18.

MACBA. La Crítica de Arte como Intervención en el Espacio Social. 2003. Disponível em: < https://www.macba.cat/es/la-critica-de-arte-como-intervencion-en-el-espacio-social> Acesso em: $11 / 06 / 18$.

MACBA. La Crítica de Arte en la Era Pospolítica. 2004. Disponível em:

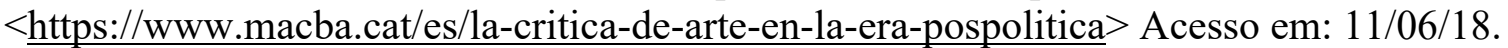

MACBA. La Herencia Inmaterial - Ensayando desde la Colección. 2014. Disponível em: $<$ https://www.macba.cat/es/expo-coleccion-macba-2014> Acesso em 11/06/18.

MACBA. La Historización de los Setenta. 2012e. Disponível em:

$<$ https://www.macba.cat/es/mesa-historizacion-setenta $>$ Acesso em 11/06/18.

MACBA, la derecha, la izquierda y los ricos, documentário em vídeo. Direção: Jorge Luis Marzo: SUB (Societat U de Barcelona), 2013. Online (87 min).

MACBA. La noche del apagón. 2014e. Disponível em: $<$ https://www.macba.cat/es/la-nochedel-apagon-> Acesso em 22/08/18.

MACBA. La Periodización del Arte Contemporáneo. 2012f. Disponível em: $<$ https://www.macba.cat/es/seminario-derivas-teoria-> Acesso em 11/06/18.

MACBA. La Revolución (no será) Retransmitida. 2004. Disponível em: $<$ https://www.macba.cat/es/la-revolucion-no-sera-retransmitida $>$ Acesso em: 11/06/18.

MACBA. La Pasión Segundo Carol Rama. Disponível em: $<$ https://www.macba.cat/es/expocarol-rama $>$ Acesso em 12/06/18.

MACBA. La Tribu Inefable 2016hh. Disponível em: https://www.macba.cat/es/la-tribu-inefable. Acesso em 12/06/18.

MACBA. La Utopía es posible. ICSID. Eivissa, 1971. 2012h. Disponível em:

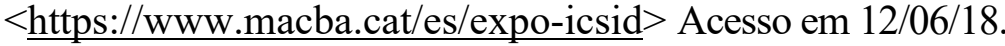


MACBA. Laboratorio artístico. 2016v. Disponível em: https://www.macba.cat/es/laboratorioartistico. Acesso em 12/06/18.

MACBA. Las Derivas de la Teoria. Disponível em: < https://www.macba.cat/es/seminarioderivas-teoria-ii > Acesso em 12/06/18.

MACBA. Le Corbusier y Jean Genet en el Raval. 2012i. Disponível em: https://www.macba.cat/es/expo-le-corbusier. Acesso em 12/06/18.

MACBA. Lecturas de uma Colección. Disponível em: $<\underline{\text { https://www.macba.cat/es/lecturas- }}$ de-una-coleccion> Acesso em 12/06/18.

MACBA. Lejos de los Árboles. Jacinto Esteva en la Colección MACBA. Disponível em:

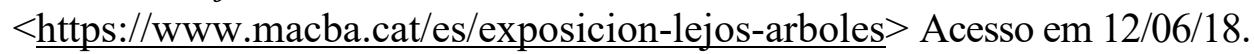

MACBA. Lluvia de sonidos. 2016ee. Disponível em:

https://www.macba.cat/uploads/20160111/programa_pluja_de_sons_a_la_capella_CAST.pdf. Acesso em 12/06/18.

MACBA. LOREM IPSUM. 2017ff. Disponível em: https://www.macba.cat/es/lorem-ipsum/. Acesso em 12/06/18.

MACBA. Los Nuevos Productivismos. Disponível em: $<$ https://www.macba.cat/es/losnuevos-productivismos $>$ Acesso em 11/06/18.

MACBA. Los ochenta, ficciones de um futuro anterior. 20171. Disponível em:

https://www.macba.cat/es/los-ochenta-ficciones-de-un-futuro-anterior. Acesso em 11/06/18.

MACBA. Los ochenta a contrapelo. Disponível em: https:/www.macba.cat/es/los-ochenta-acontrapelo. Acesso em: 17/08/18.

MACBA. MACBA 2014-2016. Nuevos objetivos, métodos de trabajo y líneas de investigación. Museu de Arte Contemporânea de Barcelona, 2014d.

MACBA. MACBA Collage Lab. 2016t. Disponível em: https://www.macba.cat/en/macbacollage-lab-september. Acesso em: 17/08/18.

MACBA. Martha Rosler: God Bless America. 2017f. Disponível em: https://www.macba.cat/es/expo-coleccion-macba-martha-rosler-god-bless-america. Acesso em: $17 / 08 / 18$.

MACBA. Mesa redonda La Utopia es posible. 2012m. Disponível em: https://www.macba.cat/es/mesa-redonda-ibiza-1971. Acesso em: 17/08/18.

MACBA. Microrracismos. 2017z. Disponível em: https://www.macba.cat/en/microrracismos. Acesso em: 17/08/18.

MACBA. Miradas sobre el museo. 1996. Disponível em: $<$ https://www.macba.cat/es/expomiradas-sobre-el-museo/1/exposiciones-anteriores/expo>Acesso em 20/08/18. 
MACBA. Miralda MADEINUSA. 2016e. Disponível em: <https://www.macba.cat/es/expomiralda-madeinusa $>$ Acesso em: 17/08/18.

MACBA. Miro en el Espejo y me Veo. 2017jj. Disponível em:

https:/www.macba.cat/es/miro-en-el-espejo-y-me-veo-loop-2017. Acesso em: 17/08/18.

MACBA. Moderno y Presente. Cambio de siglo em la Colección MACBA. 2011c. Disponível em: $<$ https://www.macba.cat/es/moderno-y-presente-cambio-de-siglo-en-la-coleccion-macba-

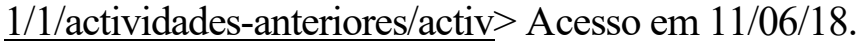

MACBA. Modernologías. 2009b. Disponível em: $<$ https://www.macba.cat/es/expomodernologias $>$ Acesso em 12/06/18.

MACBA. Modernologías - Artistas Contemporáneos Investigan la Modernidad y el Modernismo. Disponível em: <https://www.macba.cat/es/catalogo-modernologias $>$ Acesso em $11 / 06 / 18$.

MACBA. Modernos y Contemporáneos. Diálogos Intergeneracionales. 2014a. Disponível em: $<$ https://www.macba.cat/es/visitas-guiadas-modernos-y-contemporaneos $>$ Acesso em $12 / 06 / 18$.

MACBA. Motor de Modernidad - Grupo R. Arquitectura, Arte y Diseño. Disponível em: < https://www.macba.cat/es/expo-grup-r> Acesso em 12/06/18.

MACBA. Muestreo \#1. 2017a. Disponível em: https://www.macba.cat/es/expo-muestreo-1 Acesso em: 17/08/18.

MACBA. Muestreo \#2: This is mail art. Disponível em https://www.macba.cat/es/muestreothis-is-mail-art Acesso em: 17/08/18.

MACBA. Musée d'Art Ancien, Département d'Art Moderne. Cómo Repensar las Organizaciones Culturales Ante las Nuevas Relaciones entre Arte y Economía. Disponível em: $<$ https://www.macba.cat/es/musee-dart-ancien-departement-dart-moderne-comorepensar-las-organizaciones-culturales-ante-las-nuevas-relaciones-entre-arte-y-economia-> Acesso em 11/06/18.

MACBA. Museo de Futuros Naturales. 2016ff. Disponível em: https://www.macba.cat/es/museo-de-futuros-naturales. Acesso em 11/06/18.

MACBA. Museo de Narrativas Paralelas - En el Marco de la Internacional. 2011d. Disponível em: $<\underline{\text { https://www.macba.cat/es/expo-museo-de-las-narrativas-paralelas }>\text { Acesso }}$ em 11/06/18.

MACBA. Museo Molecular. ¿Es Posible la Gestión Desterritorializada y em Red del Patrimonio Cultural. 2008c. Disponível em: $<$ https://www.macba.cat/es/museo-molecular-esposible-la-gestion-desterritorializada-y-en-red-del-patrimonio-cultural- $>$ Acesso em 11/06/18.

MACBA. Museo Oral de la Revolución. 2013d. Disponível em:

$<$ https://www.macba.cat/es/sec-museo-oral-de-la-revolucion>Acesso em 12/06/18. 
MACBA. Nancy Spero. Disidanzas. 2008e. Disponível em: $<$ https://www.macba.cat/es/exponancy-spero> Acesso em 12/06/18.

MACBA. Narración, autonomía, multitud. Disponível em:

$<$ https://www.macba.cat/es/narracion-autonomia-multitud $>$ Acesso em: 11/06/18.

MACBA. Nitrato. Disponível em: $<$ https://www.macba.cat/es/nitrato-xavier-ribas-presentacion- $>$ Acesso em 11/06/18.

MACBA. No podemos prometer que hagamos otra cosa que experimentar. 2011i. Disponível em: https://www.macba.cat/es/no-podemos-prometer-que-hagamos-otra-cosa-queexperimentar. $>$ Acesso em 11/06/18.

MACBA. No Trabajéis Nunca. 2017t. Disponível em: https://www.macba.cat/en/y-ensemana-santa-no-trabajeis-nunca. Acesso em 11/06/18

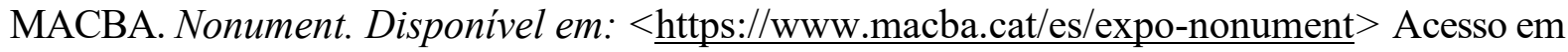
11/06/18.

MACBA. Nuevas Abstracciones. 1996. Disponível em: $<$ https://www.macba.cat/es/exponuevas-abstracciones/1/exposiciones-anteriores/expo>Acesso em 20/08/18.

MACBA. Nuevos Derechos, Movimientos Sociales y Modelo de Ciudad. 2008b. Disponível em: $<$ https://www.macba.cat/es/nuevos-derechos-urbanos-movimientos-sociales-y-modelode-ciudad $>$ Acesso em 11/06/18.

MACBA. Otras estéticas geopoliticas. Disponível em: $<$ https://www.macba.cat/es/otrasesteticas-geopoliticas $>$ Acesso em: 11/06/18.

MACBA. Obama, el Mundo y la Construcción de Otro Mundo Posible. Disponível em: $<$ https://www.macba.cat/es/obama-el-mundo-y-la-construccion-de-otro-mundo-posible $>$ Acesso em $11 / 06 / 18$.

MACBA. Ocupar, Desbordar y Cooperar - Encuentro de Saberes sobre la Nueva Onda Global. 2013a. Disponível em: $<$ https://www.macba.cat/es/seminario-ocupar-desbordar-cooperar $>$ Acesso em 11/06/18.

MACBA. Otra visualidad. El discurso de la exposición / la exposición del discurso. Disponível em: $<$ https://www.macba.cat/es/-la-exposicion-del-discurso $>$ Acesso em: 11/06/18.

MACBA. Palestina En/Sin el Museo. 2015c. Disponível em: https://www.macba.cat/es/palestina-en-sin-el-museo. Acesso em: 11/06/18. MACBA. Parlem de...2017ii. Disponível em: https://www.macba.cat/en/parlem-de. Acesso em: 11/06/18.

MACBA. Pasado Inquieto. Narrativas y Fantasmas de la Exposición Internacional de Arte en Solidariedad con Palestina, 1978. Disponível em: $<\underline{\text { https://www.macba.cat/es/expo-pasado- }}$ inquieto> Acesso em 11/06/18. 
MACBA. Patrimonio común e institución pública: del derecho del autor al derecho del público. In: Quaderns portátils - Selección de textos de la Agenda informativa del MACBA Ag 2004-2006. $5^{\text {a }}$ edição. Museu de Arte Contemporânea de Barcelona, Barcelona, 2006.

MACBA. ¿Pero dónde está la costa? Rodney Graham y el Arte en Vancouver. 2010h. Disponível em: https://www.macba.cat/es/expo-poesia-brossa. Acesso em: 17/08/18.

MACBA. PI(E)CE. 2016W. Disponível em: https://www.macba.cat/es/bamba-lina. Acesso em: $17 / 08 / 18$.

MACBA. Poesía Brossa. 2017c. Disponível em: https://www.macba.cat/es/expo-poesiabrossa. Acesso em: 17/08/18.

MACBA. Poéticas del Signo y del Détour. 2017m. Disponível em: https://www.macba.cat/es/poeticas-del-signo-y-del-detour. Acesso em: 17/08/18.

MACBA. Poner las Mujeres en el centro. 2017i. Disponível em: https://www.macba.cat/es/encuentro-con-raquel-gutierrez. Acesso em: 17/08/18.

MACBA. Prácticas de cultura visual. Disponível em: $<\underline{\text { https://www.macba.cat/practicas-de- }}$ cultura-visual> Acesso em: 11/06/18.

MACBA. Pregunta a los comissários. 2013g. Disponível em: https://www.macba.cat/es/pregunta-a-los-comisarios. Acesso em: 11/06/18.

MACBA. Privatizar la cultura. Disponível em: $<$ https://www.macba.cat/es/privatizar-lacultura $>$ Acesso em: 11/06/18.

MACBA. Procesos Constituyentes. 2016g. Disponível em https://www.macba.cat/es/jornadaprocesos-constituyentes-2 Acesso em: 17/08/18.

MACBA. Programa 2016. Museu de Arte Contemporânea de Barcelona, 2016a.

MACBA. Publicaciones. s.d. Disponível em:

$<\underline{\text { https://www.macba.cat/es/publicaciones }}>$ Acesso em 20/08/18.

MACBA. Punk. Sus Rastros em el Contemporáneo. 2016c. Disponível em:

$<$ https://www.macba.cat/es/expo-punk> Acesso em: 17/08/18.

MACBA. Qué es el MACBA? 2015b. Disponível em: https://www.macba.cat/es/que-es-elmacba- Acesso em: 20/10/18.

MACBA. ¿Qué es lo que hace que la modernidade sea tan. Diferente, tan atractiva para los artistas visuales de hoy? 2009g. Disponível em: https://www.macba.cat/es/que-es-lo-quehace-que-la-modernidad-sea-tan-diferente-tan-atractiva-para-los-artistas-visuales-de-hoy-. Acesso em: 20/10/18.

MACBA. Rastros de Nitrato - Fotografía, Capital Financiero y Movimiento Obrero.

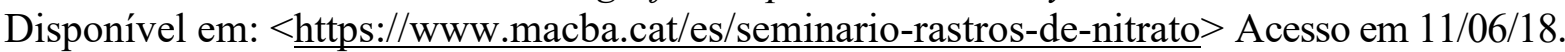


MACBA. Reconstruyendo Office Baroque: en la Lógica del Turismo Urbano. 2012a. Disponível em: $<$ https://www.macba.cat/es/mesa-redonda-officebaroque $>$ Acesso em $11 / 06 / 18$.

MACBA. Redes: modos de acción y producción en la sociedad global. Disponível em: $<\underline{\text { https://www.macba.cat/es/redes-modos-de-accion-y-produccion-en-la-sociedad-global }>}$ Acesso em: 11/06/18.

MACBA. Ritual \#05. 2012j. Disponível em: https:/www.macba.cat/es/macba-se-vivesalonnieres. Acesso em: 11/06/18.

MACBA. Rosemarie Castoro: enfocar al infinito. 2017d. Disponível em https://www.macba.cat/es/rosemarie-castoro-enfocar-al-infinito Acesso em: 17/08/18.

MACBA. Sexualidad, culpa y lo real. 2012c. Disponível em:

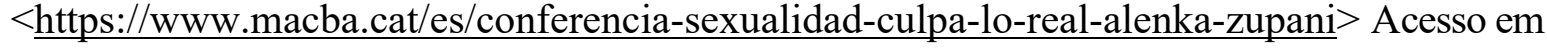
$11 / 06 / 18$.

MACBA. Sick 80s/ Malditos Ochenta. Crisis del SIDA, Arte y Guerrilla Contrabiopolítica. 2010. Disponível em: $<$ https://www.macba.cat/es/-malditos-ochenta-crisis-del-sida-arte-yguerrilla-contrabiopolitica $>$ Acesso em 11/06/18.

MACBA. Singalit Lindau. 2015. Disponível em: < https://www.macba.cat/en/publicationsigalit-landau $>$ Acesso em 22/08/18.

MACBA. Sobre Crédito, Autoestima y Sharing: Introducción a la Condición Neoliberal. 2011b. Disponível em: < https://www.macba.cat/es/seminario-credito-autoestima-y-sharing $>$ Acesso em 12/06/18.

MACBA. Sobre el legado de Art and Language. 2013f. Disponível em: https://www.macba.cat/es/seminario-art-language. Acesso em 12/06/18.

MACBA. Sombras y Silencios o los Fantasmas que Vuelven como la Primera Vez. Ciclo de Cine. 20161. Disponível em: https://www.macba.cat/es/cine-andres-duque-sombras-silenciosfantasmas/1/actividades/alta_newsletter. Acesso em 12/06/18.

MACBA. Subalternidad y Representación. 2008. Disponível em: $<$ https://www.macba.cat/es/subalternidad-y-representacion> Acesso em 11/06/18.

MACBA. Sujetos Visibles/historias Visuales. Los Relatos Femenistas, Queer y Trans Frente la Historiografia del Arte. 2009. Disponível em: <https://www.macba.cat/es/-historiasvisuales-los-relatos-feministas-queer-y-trans-frente-a-la-historiografia-del-arte $>$ Acesso em $11 / 06 / 18$.

MACBA. Taller de Autodefensa Verbal para Contestar a Señores y Defenderse en Situaciones Machistas. 2017bb. Disponível em: https://www.macba.cat/en/taller-deautodefensa-verbal-para-contestar-a-senyores-y-defenderse-en-situaciones-machistas. Acesso em 11/06/18. 
MACBA. Taller de dibujo y collage en torno de a la exposición Disidanzas. 2008g.

Disponível em: <https://www.macba.cat/es/taller-de-dibujo-y-collage-en-torno-de-a-laexposicion-disidanzas $>$ Acesso em 12/06/18.

MACBA. Taller Tiempo como materia. 2009e. Disponível em: https://www.macba.cat/es/tiempocomo-materia. Acesso em: 11/06/18.

MACBA. Taller Visual A - PART. 2017aa. Disponível em: https://www.macba.cat/en/tallervisual-a-part-habitacio-1418. Acesso em: 11/06/18.

MACBA. Tàpies como Sintoma - Una modernidad Sin Correspondencia. 2013. Disponível em: $<$ https://www.macba.cat/es/tapies-como-sintoma $>$ Acesso em 12/06/18.

MACBA. Tecnologías del género. 2004. Disponível em:

$<$ https://www.macba.cat/es/tecnologias-del-genero $>$ Acesso em: 11/06/18.

MACBA. The Concept of Dust: Continuous Project - Altered Annually. 2017n. Disponível em: https://www.macba.cat/es/yvonne-rainer-the-concept-of-dust. Acesso em: 11/06/18.

MACBA. The Maids. 2017. Disponível em https://www.macba.cat/es/the-maids-2ndfoundation-han-nefkens-foundation-award Acesso em: 17/08/18.

MACBA. Tiempo como materia. 2009a. Disponível em: $<$ https://www.macba.cat/es/expotiempo-como-materia $>$ Acesso em 12/06/18.

MACBA. Todo lo que nos rodea es música. 2009F. Disponível em:

https://www.macba.cat/es/todo-lo-que-nos-rodea-es-musica-. Acesso em 12/06/18.

MACBA. Todos lo Saben. 2017u. Disponível em: https://www.macba.cat/es/todos-lo-saben. Acesso em 12/06/18.

MACBA. Trabajando sobre el proyecto Atlas con Alice Creischer y Andreas

Siekmann.2009D. Disponível em: $<$ https://www.macba.cat/es/trabajando-sobre-el-proyectoatlas-con-alice-creischer-y-andreas-siekmann $>$ Acesso em 12/06/18.

MACBA. Transfiguraciones - Investigación Artística y Curatorial en Una Época de Migraciones. 2014. Disponivel em: < https://www.macba.cat/es/exposicion-efimera $>$ Acesso em 11/06/18.

MACBA. ¿Un arte global? 2002. Disponível em: $<$ https://www.macba.cat/es/un-arte-global$>$ Acesso em: 11/06/18.

MACBA. Videoclip'me. 2017x. Disponível em: https://www.macba.cat/es/videoclip-me-lasvvitch. Acesso em: 11/06/18.

MACBA. Visita a la exposición Akram Zaatari. 2017cc. Disponível em:

https://www.macba.cat/es/visita-para-los-amigos-akram-zaatari. Acesso em: 11/06/18. 
MACBA. Visita a la exposición Rosemarie Castoro. 2017dd. Disponível em:

https://www.macba.cat/es/rosemarie-castoro-enfocar-al-infinito-amics-macba. Acesso em:

$11 / 06 / 18$.

MACBA. Visitas comentas a las exposicones.Disponível em:

https://www.macba.cat/es/visitas-comentadas-a-las-exposiciones-primaria Acesso em:

$17 / 08 / 18$.

MACBA. Visita-taller. No temer é mal alguno. 2016k. Disponível em:

https://www.macba.cat/es/taller-no-temere-mal-alguno. Acesso em 03/11/2018.

MADZOSKI, Vesna. A invenção dos curadores. In: Arte \& Ensaios, Revista do Programa de Pós-Graduação em Artes Visuais: EBA/UFRJ. n. 28, dezembro de 2014.

MARÍ I RIBAS, Bartomeu. Bartomeu Marí: El nuevo modelo MACBA está inspirado en el IVAM de los 90 [online]. Entrevista concedida a José Luis Pérez Pont. Eldiariocv.es, 06 de março de 2014. Disponível em: $<\underline{\text { https://www.eldiario.es/cv/culturamakma/Bartomeu-Mari-MACBA-inspirado- }}$ IVAM_6_235936428.html> Acesso em 11/06/18.

MARÍ I RIBAS, Bartomeu. Projecto para el MACBA [online]. Museu de Arte Contemporânea de Barcelona, 2008. Disponível em:

$<$ http://www.macba.cat/uploads/transparencia/18.2.3.Projecte BM_2008_cas.pdf $>$ Acesso em: 11/06/18.

MARTINI, F.; MARTINI, V. Questions of Autorship in Biennial Curating. In: VAN HAL, M.; OVSTEBO, S. The Biennial Reader. Hatje Cantz, 2010, p. 262.

MASON, Rhiannon. Museums, galleries and heritage. Sites os meaning-making and communication. In: CORSANE, Gerard (Org.). Heritage, Museums and Galleries: An Introductory Reader. New York: Routledge, 2005.

MCSHINE, K. L. Essay. In: MCSHINE. K. L. (Org). Information. Nova Iorque: The Museum of Modern Art, 1970.

MNCARS. El arte de la crisis. Seminarios sobre la crisis sistêmica del capitalismo. S.d. Disponível em: http://www.museoreinasofia.es/fundacion-comunes/arte-crisis-seminariossobre-crisis-sistemica-capitalismo. Acesso em 20/10/18.

MOMA. Jennifer Licht - Director of Spaces. Nova Iorque: 1969a. Disponível em: $<$ https://www.moma.org/momaorg/shared/pdfs/docs/press_archives/4398/releases/MOMA_1 969 July-December_0091 165.pdf $>$ Acesso em 20/06/18.

MOMA. Information on Spaces Exhibition. Nova Iorque: 1969b. Disponível em: < https://www.moma.org/momaorg/shared/pdfs/docs/press_archives/4393/releases/MOMA_19 69_July-December_0086_160.pdf $>$ Acesso em 20/06/18.

MOMA. This is the way your leverage lies. The Seth Siegelaub Papers as Institutional Critique. Disponível em: < https://www.moma.org/interactives/exhibitions/2013/siegelaub/> Acesso em 20/06/18. 
MONTAÑES, J. A. El Macba “se resetea”. El País. 13 de fevereiro de 2014.

MONTE, James. Anti-Illusion: Procedures/Materials. In: Anti-Illusion: Procedures/Materials. Catálogo de exposição. Nova York: Whitney Museum of American Art, 1969.

MONTMANN, Nina. The Rise and Fall of New Institutionalism: Perspectives on a Possible Future. Institut Européen pour des Politiques Culturelles en Devenir, agosto de 2007.

OBRIST, H. U. Breve História da Curadoria. São Paulo: BEI, 2010.

O'DOHERTY, Brian. Inside the White Cube. The Ideology of the Gallery Space. São Francisco: The Lapis Press, 1986.

O'NEILL, Paul. The Culture of Curating and the Curating of Cultures. Cambridge: MIT PRESS, 2012.

PLATFORM GARANTI. Platform Garanti CAC is .... 01 jan. 2000. Disponível em: $<$ http://platformgaranti.blogspot.com.br/2000/01/> Acesso em: 27/05/17.

PRECIADO, P.B. La bèstia i el sobirà. Núvol. 20 de março de 2015. Disponível em: $<$ https://www.nuvol.com/opinio/la-bestia-i-el-sobira/> Acesso em: 25/03/18.

PUIG, Oriol. MACBA: Entre la ruptura y la reforma. Eldiario.es, 15 de maio de 2015. Disponível em: $<$ https://www.eldiario.es/catalunya/diaricultura/Museo_6_388171206.html $>$ Acesso em 28/06/18.

QUADERNS PORTÀTILS. Introducción. Ejes de trabajo y naturaleza de la Ag. In: Ag 2004-2006. Selección de textos de la Agenda Informativa del MACBA. Barcelona: 2006.

RAMOS, Anna. Entrevista - Radio Web MACBA [online]. Artecapital. Maio de 2012. Disponível em: $\leq$ https://www.artecapital.net/entrevista-141-anna-ramos-r\%C3\%A0dio-webmacba-> Acesso em: 25/03/18.

RAMOS, A. D. Introdução. In: RAMOS, A. D. (Org). Sobre o oficio do curador. Porto Alegre: Zouk, 2010.

RECTANUS. M. W. Culture Incorporated: Museums, Artists and Corporate Sponsorships. University of Minnesota Press, 2002.

RECTANUS, M. W. Globalization: Incorporating the Museum. In: MACDONALD, Sharon (Org). A Companion to Museum Studies. Blackwell Publishing, 2006.

RED CONCEPTUALISMOS DEL SUR. Ante la grave situación que afecta al MACBA [online]. 02 de abril de 2015. Disponível em: $<$ https://redcsur.net/es/2015/04/02/ante-lagrave-situacion-que-afecta-al-macba/ $>$ Acesso em: 25/03/18.

REVISTA RAMBLA. "Un museo es un actor político que no se posiciona en la política, sino que ayuda a reflexionar y cuestionarse sobre ella". 10 de dezembro de 2015. Disponível em: $<$ https://www.revistarambla.com/un-museo-es-un-actor-politico-que-no-se-posiciona-en-lapolitica-sino-que-ayuda-a-reflexionar-y-cuestionarse-sobre-ella/> Acesso em: 28/06/18. 
REVUELTA, Laura. El MACBA de Barcelona explica desde su colección "los otros" años ochenta. ABC Cultural. 27 de maio de 2014. Disponível em:

$<$ https://www.abc.es/cultura/cultural/20140526/abci-macba-herencia-inmaterial-coleccion201405261348.html> Acesso em 20/10/18.

RIBALTA, Jorge. Experimentos para una nueva institucionalidad. In: BORJA VILLEL, M. J., M. CABAÑAS, K; RIBALTA, J., Objetos relacionales. Colección MACBA 2002-2007, Barcelona: MACBA, 2009.

RIBALTA, Jorge. Mediation and Construction of Publics [online]. The MACBA Experience. Republicart. Net. Abril de 2004. Disponível em:

$<$ http://republicart.net/disc/institution/ribalta01_en.htm> Acesso em: 25/03/18.

RIBALTA, Jorge. On the Recent Events at MACBA [online]. L'internationale online. 23 de maio de 2015. Disponível em:

$<\underline{\text { http://www.internationaleonline.org/research/alter institutionality } / 25 \text { on the recent events }}$ at_macba $>$ Acesso em: 25/03/18.

SESÉ, Teresa. El MACBA mata al padre. La vanguardia. 13 de fevereiro de 2014.

SESÉ, Teresa. La polémica del Macba sacude al comité internacional de museos que preside Marí. La Vanguardia [online]. 12 de novembro de 2015. Disponível em: < https://www.lavanguardia.com/cultura/20151112/54438789169/polemica-macba-museosmari.html> Acesso em 01/11/18.

SESÉ, Teresa. Los museos de Barcelona reducen su presupuesto [online]. La Vanguardia. 30 de dezembro de 2010. Disponível em:

$<$ http://www.lavanguardia.com/cultura/20101230/54095842409/los-museos-de-barcelonareducen-su-presupuesto.html $>$ Acesso em: 29/06/18.

SMITH, Terry. Contemporary art: world currents in transition beyond globalization. In: BELTING, H.; BUDDENSIEG, A.; WEIBEL, P. The Global Contemporary: The Rise of New Art Worlds after 1989. Cambridge, Mass.: MIT Press for ZKM, Karlsruhe, 2013.

STEDELIJK. Stedelijk museum presentes: Recollections - Op Losse Schroeven_online], 28 de fevereiro de 2012. Disponível em: $<$ https://www.stedelijk.nl/en/news/stedelijk-museumpresents-recollections--op-losse-schroeven $>$ Acesso em 20/06/18.

SZEEMANN, Harald. Curator Interview. Entrevistado por Hans-Ulrich Obrist. Artforum, novembro de 1996.

TEATRO MAYOR. La Zarzuela: la mezcla perfecta entre música y teatro en un solo género [online]. Disponível em: <https://www.teatromayor.org/noticia/la-zarzuela-la-mezclaperfecta-entre-musica-y-teatro-en-un-solo-genero> Acesso em 29/06/18.

UUSITALO, Liisa. The roles of art museums - challenges to their marketing. In: UUSITALO, Liisa (Org.). Museum and visual art markets. Helsinki: Helsinki School of Economics, 2008. 
VOORHIES, James. Beyond Objecthood: the exhibition as a critical form since 1968. MIT Press, 2017.

VOORHIES, James. Prologue: to a beautiful problem. In: VOORHIES, J. (Org.). What ever happened to New Institutionalism? Sternberg Press, 2016.

WEIL, Stephen. From Being About Something to Being For Somebody. In: ANDERSON, Gail. Reinventing the Museum. The Evolving Conversation on the Paradigm Shift. Plymouth: AltaMira Press, 2012.

WELCHMAN, J.C. Introduction. In: WELCHMAN, J.C (Org.). Institutional Crtitique and After. Zurique: JRP Ringier, 2006

WILLIAMS, R.J. After Modern Sculpture: Art in the United States and Europe, 1965-70. Manchester: Manchester University Press, 2000.

WU, Chin-Tao. Privatização da cultura - a intervenção corporativa nas artes desde os anos 80. São Paulo: Boitempo, 2006. 


\section{ANEXO A - OUTRAS ATIVIDADES REALIZADAS NA GESTÃO BORJA-VILLEL}

Arte y espacio público, oficina dirigida por Sergi Aguilar e Ramon Parramon, em abril de 2000, que visou promover o debate em torno do conceito de arte pública, desde o monumento comemorativo às novas formas de intervenção na esfera pública, mostrando a evolução de instalações de caráter escultórico vinculadas ao entorno e situadas em praças e locais públicos para intervenções mais implicadas na trama social.

Capital financiero, propiedad inmobiliaria y cultura, seminário realizado em maio de 2000, cujo propósito foi construir um marco intelectual de reflexão ante o processo de transformação do espaço público urbano das cidades ocidentais, levantando as questões: de que modo a atual transformação das economias capitalistas em economias financeiras reflete na forma urbana?; Quais consequências esse processo tem sobre a negociação de espaço público e de cidadania própria das cidades ocidentais do século XIX?; De que modo os interesses imobiliários e turísticos determinam as políticas urbanísticas? Qual é o papel da arte e da cultura neste processo? Também formaram parte do debate a análise do aburguesamento e a revalorização especulativa (gentrificação) das zonas centrais e o papel instrumental das instituições culturais nesse processo, assim como a museificação ou "disneyficação" das cidades e as novas definições de público e privado.

Modernidades, curso realizado entre outubro e novembro de 2000, que propôs reconsiderar o conceito de modernidade nas artes do século XX, por meio das questões: de onde veio e como foi gerado o conceito de modernidade como categoria central da arte a partir do século XX? Que consequências essa noção tem sobre as distintas artes, como pintura, música, teatro, arquitetura, cinema, fotografia...? Como se pode definir o moderno? Como se reinterpreta esse conceito ao longo do século XX? O que acontece com a modernidade após a modernidade?

De la política a lo político, oficina de leituras da obra de Jacques Rancière, realizadas entre maio e junho de 2001 e dirigidas pelo professor de estética Xavier Antich, que iniciam um novo formato de oficinas teóricas organizadas pelo MACBA, dirigidas a estudantes avançados e profissionais de distintos âmbitos da produção cultural, em que foram propostas a leitura e discussão em grupo de importantes textos do pensamento contemporâneo. 
Estética y política. Un vínculo para replantear, eminário ministrado por Jacques Rancière, em maio de 2002, em que foram abordados os temas: "Estética e política. Um vínculo que convém reformular"; "Políticas estéticas. Como se manifesta hoje em dia a oposição entre uma arte crítica, que transforma nossos modos de representação, e uma arte proposicional, que inventa os dispositivos espaço-temporais de outro con-viver?”; "Estado da política, estado da arte. Como pensar em geral a relação entre as formas sensíveis elaboradas pelos procedimentos artísticos e as formas do dissenso político?"; "Lugares e instituições artísticas. Onde nos encontramos a respeito dos quadros simbólicos da cultura, das realidades das 'políticas culturais' e da tradição teórica da 'crítica da cultura'?”; “O que é hoje em dia uma arte crítica? E a arte contemporânea? Ela está condenada à modéstia 'relacional', ou pode contribuir a reconstruir um espaço político?’.

¿Un arte global? Trata-se da temática do curso de arte e cultura contemporânea, realizado de outubro a novembro de 2002, que buscou analisar as condições criadas pela globalização, e, em particular, seu impacto sobre a arte e a cultura. Explica-se como o debate sobre a globalização cultural foi geralmente pautado no conflito entre local e global, mantendo relação com suas consequências homogeneizadoras: um processo de subordinação cultural em escala mundial. Tal debate, por sua vez, deu atualidade à reflexão sobre a construção de identidades, abordada pelos estudos culturais a propósito das subculturas enquanto formas de antagonismo entre posições hegemônicas e subordinadas, redefinindo, assim, oposições tradicionais de centro e periferia ou alta cultura e cultura popular.

El relanzamiento de la crítica, seminário ministrado pelos sociólogos Luc Boltanski e Eve Chiapello, em junho de 2003, a respeito de seu libro El nuevo espíritu del capitalismo (2002), em que os autores traçam os contornos do novo espírito do capitalismo a partir de uma análise direta dos textos de gestão empresarial que inspiraram novos modelos de organização das empresas e redefiniram o estatuto da força de trabalho que essas exploram: desde meados dos anos 70, o capitalismo renunciou ao princípio fordista da organização hierárquica do trabalho para desenvolver uma nova organização em rede, fundada sobre a iniciativa dos atores e a autonomia relativa de seu trabalho, tudo ao preço de sua seguridade material e psicológica. 
Narración, autonomía, multitud, seminário ministrado em abril de 2003 pelos cinco autores bolonheses que integram o grupo Wu Ming, os quais pertenceram ao núcleo histórico do Luther Blissett em 1994, que objetivou colocar em prática um projeto de guerrilha comunicativa e sabotagem cultural. O Wu Ming apresentou, no MACBA, sua obra Esta revolución no tiene rostro. Escritos sobre literatura, catástrofes, mitopoiesis (Acuarela Libros, 2003), com textos que abarcam o ciclo de lutas globais desenvolvido desde o zapatismo até o milhão de pessoas que clamaram contra a guerra em novembro de 2002. Diante da obra, o grupo demonstra sua competência ao compreender no que implica, nos últimos tempos, a lição gramsciana sobre a luta pela hegemonia na cultura popular, além da crença de que o produtor cultural não pode operar senão sob o conflito de novas forças produtivas e contradições sociais.

La crítica de arte como intervención en el espacio social, curso dirigido por Manuel Asensi e Xavier Antich, entre fevereiro e junho de 2003, que propôs a reflexão sobre o papel político da crítica de arte, não apenas do sentido de sua função social, mas também quanto as suas possibilidades de ação e intervenção na esfera pública, levantando as questões: Como se pode estabelecer um vínculo entre os diferentes tipos de crítica social ao capitalismo e à crítica de arte? É pura coincidência que em ambos se fale de crítica? Desse modo, procurouse questionar as concepções de arte derivadas da leitura schilleriana de Kant, fazendo uso das tradições da hermenêutica, a desconstrução, o feminismo e os estudos culturais a fim de estabelecer um fio condutor plural e contraditório.

La construcción del público. Neste seminário, realizado entre novembro e dezembro de 2003, pretendeu-se analisar criticamente os modelos de trabalho educativo e de mediação nos museus, em particular o imperativo de adotar estratégias de marketing de públicos a que se veem submetidas hoje as instituições culturais. Participaram Roger Buergel, Alice Creischer y Andreas Siekman, Catherine David, Michael Warner, Marina Garcés, César de Vicente, Brian Holmes e Paolo Virno.

La crítica de arte en la era pospolitica, oficina dirigida por Manuel Asensi y Xavier Antich, entre janeiro e março de 2004, que procurou refletir a respeito de como seria possível pensar e atuar no político após o fim das grandes ideologias. Uma vez que não é inverossímil conceber a sociedade como uma rede de sistemas inter-relacionados, a crítica de arte se vê 
atrelada à mesma problemática da crítica em seu sentido político. Diante disso, a oficina buscou indagar sobre as formas adotadas pela crítica de arte na era da pós política.

Tecnologías del género, oficina ministrada por Paul B. Preciado, entre fevereiro e novembro de 2004, acerca de identidades minoritárias e suas representações críticas, que buscou levantar as questões: Como repensar o feminismo na era pós-fordista? Qual poderia ser a ação política adequada a um tempo pós-orgânico? Qual é a biopolítica dos corpos pósmodernos?

La revolución (no será) retransmitida, jornada realizada em abril de 2004, que contou com a participação de Carles Ameller, Franco Berardi, Naomi Klein, Dee Dee Halleck, Marcelo Expósito e Avi Lewis, e teve como objetivo tecer um relato sobre o tempo histórico e político que tem seu mito fundacional na aparição dos equipamentos portáteis de vídeo e na eclosão das experiências de comunicação descentralizada nos 70. Considerou-se o nascimento de um novo paradigma (contra) informativo, tanto no campo da comunicação como no artístico, enraizado tanto em determinadas práticas artísticas conceptuais e de crítica institucional, como nos fenômenos contraculturais e anti-institucionais do ciclo de lutas dos anos setenta. Tratava-se de um novo paradigma, do qual brotaram práticas que experimentavam com a dimensão comunicativa para interpelar e contribuir para a conformação de novos sujeitos sociais e políticos.

Otras estéticas geopolíticas. Com o tema Aspectos da arte contemporânea nas periferias do sistema mundial, o curso pretendeu realizar uma investigação sobre como a modernidade artística se produziu historicamente de formas não ortodoxas, longe dos centros de hegemonia cultural ocidental. Ministrado por Cuauhtémoc Medina, Brian Holmes, Marina Garcés e Beatriz Preciado entre outubro e novembro de 2004.

Redes: modos de acción y producción en la sociedad global, curso monográfico dirigido por Jesús Carrillo, em abril de 2005, que pretendeu realizar uma análise da cultura contemporânea a partir da constatação da expansão do paradigma da rede, imposto na organização dos processos econômicos, políticos e de relação social, e que deriva da intensificação dos fluxos comunicacionais durante o último terço do século XX. 
La condición del museo y el destino de la crítica institucional, seminário ministrado em janeiro de 2006 pelo historiador da arte Benjamin Buchloh, em que esse expôs uma nova leitura de sua tese, e analisou figuras chave do movimento conceitual como Marcel Broodthaers, Hans Haacke e Louise Lawler, entre outros.

Descentrados. Otros relatos del conceptualismo (argentino y latinoamericano), curso ministrado por Ana Longoni entre janeiro e fevereiro de 2006, com a participação de Simón Marchán-Fiz e Marcelo Expósito, que pretendeu revisar um conjunto de práticas e ideias vanguardistas que tiveram lugar na Argentina e em outros países da América Latina nos anos sessenta e setenta, práticas essas que tiveram em comum o questionamento radical do estatuto autônomo da arte.

Otra visualidad. El discurso de la exposición / la exposición del discurso, seminário realizado em novembro de 2006, que pretendeu estabelecer um marco para uma discussão sobre o papel e o significado da exposição como dispositivo específico da esfera pública e, mais além, sobre a ideologia e as consequências dos regimes de visibilidade nas práticas culturais contemporâneas. Contou com a participação de Martin Jay, Jonathan Crary, Marius Babias, Roger Buergel e Martha Rosler.

Privatizar la cultura, conferência de Chin-tao $\mathrm{Wu}$, autora do livro Privatização da cultura: a intervenção corporativa nas artes desde os anos 80, em novembro de 2007, na qual foi analisada a relação empresarial com os museus, os caminhos seguidos pelas elites sociais e mercantis, e como essas companhias passaram a se interessar pela infraestrutura do mundo artístico, convertendo seus edifícios em exposições de arte. 


\section{ANEXO B - ATIVIDADES REALIZADAS DURANTE A GESTÃO BARTOMEU MARÍ: O DEBATE POLÍTICO NO MUSEU}

Curso El Arte Tras los Femenismos: Hacia una Historiografia Postfemenista del Arte Contemporáneo, ministrado pelo teórico e curador trans Paul B. Preciado entre março e abril de 2008 .

Laboratório Museo Molecular. ¿Es Posible la Gestión Desterritorializada y en Red del Patrimonio Cultural?, realizado em junho de 2008 como parte do Programa Translate. Beyond Culture: The Politics of Translation do European Institute for Progressive Cultural Policies (EIPCP), com objetivo de pensar um novo tipo de institucionalidade e um tipo de museu pós-colonial.

Mesa redonda Nuevos Derechos, Movimientos Sociales y Modelo de Ciudad, realizada em outubro de 2008, por ocasião da publicação de París, capital de la modernidad, de David Harvey.

Seminário Después del Neoliberalismo: Ciudades y Caos Sistémico, em novembro de 2008.

A palestra Obama, el Mundo y la Construcción de Otro Mundo Posible, ministrada, em janeiro de 2009, pelo sociólogo estadunidense Immanuel Wallerstein, no contexto dos seminários El arte de la crisis. Seminarios sobre la crisis sistémica del capitalismo, organizados pelo Museo Nacional Centro de Arte Reina Sofía (MNCARS) e o projeto Universidad Nómada, com a colaboração do MACBA.

Seminário Conocimiento Contra el Capitalismo Financiero, organizado pelo MACBA em colaboração com a Escuela Europea de Imaginación Social, em dezembro de 2011, e coordenado por Francesco Berardi, em que artistas, filósofos e poetas foram convidados a imaginar un futuro livre do dogma da época obscurantista da especulação financeira. 
Seminário Sobre Crédito, Autoestima y Sharing: Introducción a la Condición Neoliberal, realizado em dezembro de 2011, ministrado pelo filósofo Michel Feher, e que pretendeu analisar a condição neoliberal nos âmbitos da governança corporativa, da política governamental, das redes sociais e dos protocolos eróticos.

Mesa redonda Reconstruyendo Office Baroque: en la Lógica del Turismo Urbano, na qual, em junho de 2012, a partir do filme Office Baroque, de Gordon Matta Clark, procurouse debater a atualidade das relações entre a arte contemporânea, o turismo cultural e a identidade urbana.

Encontro com a escritora, professora e ativista feminista Silvia Federici, em maio de 2012, acerca dos contínuos processos de expropriação dirigidos aos corpos, saberes e à reprodução das mulheres.

Seminário Ocupar, Desbordar y Cooperar - Encuentro de Saberes sobre la Nueva Onda Global, cujo propósito foi traçar certos eixos temáticos em relação às gramáticas do protesto, às políticas expressivas, às críticas da representação e às experimentações organizativas, a partir de casos de estudo como os movimentos Occupy, $15 \mathrm{M}$ e os movimentos estudantis em países como Chile, Colômbia, México e Canadá, com a participação de Franco "Bifo" Berardi, Isabell Lorey, Gerald Raunig, Nicolás Sguiglia e a Plataforma de Afectados por la Hipoteca (PAH).

Jornada Sexualidad, culpa y lo real, realizada, em julho de 2012, em colaboração com a Universidade Autônoma de Barcelona (UAB), cujo objetivo foi a formação de um espaço de diálogo plural e diverso de pensamento do feminino arraigado na experiência e, em particular, na representação da experiência gerada desde o corpo em relação à diferença sexual, e que contou com uma oficina de pesquisa na UAB e uma conferência no Auditório do MACBA, ministrados pelas professoras Alenka Zupancic e Joan Copjec.

Seminário Imaginarios postcoloniales de África, realizado em fevereiro de 2013 e dirigido pelos historiadores da arte T.J. Demos e Hilde Van Gelder, que combinou um debate sobre a condição pós-colonial com a apresentação de documentários, produzidos 
especificamente para o projeto, por autores como Herman Asselberghs, Sven Augustijnen, Renzo Martens e Els Opsomer.

Seminário Rastros de Nitrato - Fotografía, Capital Financiero y Movimiento Obrero, organizado, em outubro de 2013, junto ao Museo Universidad de Navarra, que abordou as diversas perspectivas históricas que tomaram a fotografia como modelo para representar a circulação de capitais, e contou com a participação de Pablo Artaza, historiador do movimento operário, Max Jorge Hinderer, historiador e crítico de arte, Andrea Jösch, historiadora da fotografia, Louise Purbrick, historiadora, e Xavier Ribas, fotógrafo.

Seminário El Ballroom tiene algo que decir sobre el ser humano y la lucha por la libertad, ministrado pelo téologo queer e ativista Michael Roberson, em dezembro de 2013, sobre a cultura Ballroom originada no Harlem, em Nova Iorque. Partindo dos discursos e práticas radicais dos feminismos afro americanos e da teologia da liberação negra, o seminário visou analisar coletivamente as técnicas corporais e as estratégias performativas que permitiram à cultura House/Ballroom enfrentar a crise da AIDS e desmantelar as configurações opressivas provenientes da intersecção entre o racismo, o sexismo, a pobreza e outras formas de discriminação.

Debate Del Monumento al Nonumento, realizado em outubro de 2014, entre Francesc Muñoz, professor de Geografia e diretor do Observatório de Urbanização da Universidade Autônoma de Barcelona, Juan José Lahuerta, arquiteto e responsável pelas coleções do MNAC, e Josep Bohigas, arquiteto e curador da exposição Nonumento, sobre como as linguagens artísticas podem reinterpretar a tradição do monumento. 


\section{ANEXO C - ATIVIDADES REALIZADAS DURANTE A GESTÃO BARTOMEU MARÍ: A PROPOSIÇÃO DE NARRATIVAS CONTRA-HEGEMÔNICAS DA HISTÓRIA DA ARTE}

A exposição Tiempo como matéria, de 320 obras da coleção MACBA, entre maio e agosto de 2009, que apresentou as novas linhas de interesse e investigação prioritárias que o MACBA passou a adotar a partir de 2008. Desse modo, o fato de a coleção ter começado a reunir, nos anos anteriores, documentos que funcionavam como obras de arte, tais quais os trabalhos de coletivos de artistas e ativistas, como Grup de Treball e Tucumán Arde, isso não implicava necessariamente em renunciar à possibilidade de coleção de grandes obras de artistas significativos da atualidade. Assim, objetivava-se formar uma coleção que explicasse a passagem do século XX ao XXI, tratando das formulações das últimas utopias do século passado, bem como de sua crise, mas que também abordasse o presente, com suas complexidades e contradições.

A apresentação, entre julho de 2010 e janeiro de 2011, de obras selecionadas e até então nunca expostas da Coleção MACBA, em que os critérios tradicionais de ordem cronológica foram voluntariamente substituídos, em benefício de uma disposição de caráter mais flexível e fluido. Desse modo, a contiguidade, em um mesmo espaço, de obras e autores semelhantes, seja por geração, materiais e formatos, discurso, escola, ideias compartilhadas ou vínculos de amizade entre os artistas, entre outros critérios, respondeu ao objetivo de potencializar um percurso que fosse liberado da disciplina historicista, com ela rompendo e convidando o público a estabelecer relações mais complexas, aleatórias, sugestivas e livres.

A apresentação de obras selecionadas da Coleção MACBA sob o título Moderno y Presente - Cambio de Siglo en la Colección MACBA, em exibição de fevereiro a setembro de 2011, que partiu da tese de que a eclosão estética da modernidade na Catalunha teve lugar a partir de 1950, e não no princípio do século XX, como ocorreu em outros países da Europa. Assim, de acordo com o texto curatorial, desde então, e provavelmente até 1992, a prática de arte deveria considerar-se em correspondência com as de arquitetura e design, como defendem autores como Enric Franch e Valentín Roma.

A exposição Episodios Críticos (1957-2011). Colección MACBA, em exibição entre novembro de 2012 e fevereiro de 2013, que tratou das periódicas crises da arte 
contemporânea, desde os anos sessenta, sugerindo os antecedentes do que atualmente se considera uma crise sistêmica, e de modo a construir um itinerário de momentos críticos. A exposição ocupou os três andares do Museu e foi dividida em seis episódios, que podiam ser lidos com relativa autonomia: Trabajo, Poder y Control; Voyeurismo, Fetichismo y Narcisismo; Fisuras; Déconnage; El Arte de la Primera Globalización; Hay que Huir del Contenido como de una Plaga.

A exposição La Herencia Inmaterial - Ensayando desde la Colección, em cartaz de maio de 2014 a maio de 2015, fez parte do projeto Aquí comienza nuestra historia, uma série de três exposições por meio das quais o MACBA pretendeu investigar criticamente sua coleção, explorando os marcos políticos, as colisões culturais e os momentos de ruptura onde se inscreveram as práticas da arte desde o final dos anos setenta até o início dos noventa, tudo a partir das linhas de trabalho que ordenam as atividades gerais do Museu.

Entre as exposições temporárias não ligadas à coleção que buscaram oferecer alternativas ao cânone da História da Arte, notamos:

A exposição Modernologías - Artistas Contemporáneos Investigan la Modernidad y el Modernismo, em cartaz entre setembro de 2009 e janeiro de 2010, sob curadoria de Sabine Breitwieser, cujo objetivo foi questionar as condições e os limites da modernidade e do modernismo, bem como revelar novas interpretações e "modernismos desconhecidos" em países a cujos protagonistas haviam sido designados papeis até então marginais no que diz respeito a essa temática.

A exposição Arte, dos puntos - Barcelona Vive el Arte Contemporáneo, em exibição entre julho de 2013 e janeiro de 2014 e produzida pelo MACBA junto à Fundação La Caixa. De acordo com o texto curatorial, tratou-se de uma colaboração que permitiu ampliar o conjunto de narrações sobre o passado recente e oferecer ao visitante melhores condições para entender a contemporaneidade, percorrendo as tensões que atravessaram a modernidade e a vanguarda e confrontando obras e documentos do passado com a criação e as linguagens contemporâneas. A exposição se dividiu entre os espaços do MACBA e os do centro cultural CaixaForum. 
A exposição Nonumento, um projeto em que o MACBA convidou 28 artistas de seu entorno para que refletissem sobre como se poderia incidir atualmente, a partir de práticas artísticas, sobre os problemáticos vínculos entre acontecimento, comemoração, estética e cidade. De acordo com o informe curatorial, o resultado foi a realização de um conjunto de propostas inéditas, especificamente concebidas para a exposição, pelas quais observou-se de que modo as linguagens artísticas reinterpretaram a tradição do monumento. Ainda, a exposição pretendeu atuar como um laboratório aberto acerca da iminente proliferação de símbolos que colonizam os espaços reais e visuais do entorno no Museu, uma plataforma discursiva com o objetivo de investigar quais eram as condições sob as quais os artistas se incorporavam a esses debates urgentes.

A exposição-investigação Transfiguraciones - Investigación Artística y Curatorial en Una Época de Migraciones, realizada em junho de 2014, que reuniu artistas e curadores internacionais que colaboraram para o projeto MeLa, Museos europeos en una época de migraciones, em torno de questões como: em que medida a globalização, os meios digitais e os modelos variáveis de migração afetam a forma de entender e experimentar a obra de arte contemporânea? Como os artistas se relacionam com os curadores de exposições para refletir sobre a arte contemporânea através da obra, da exposição e da coleção? Como trabalham os curadores com as novas formas de produção artística, especialmente com obras de arte imateriais que se distanciam das formas convencionais de exposição, coleção e arquivo? Participaram do projeto as seguintes instituições, artistas e curadores: MACBA, com o curador Bartomeu Marí e o artista Lawrence Abu-Hamdan; Bétonsalon - Centre for Art and Research, com a curadora Mélanie Bouteloup e a artista Camille Henrot; Whitechapel Gallery com a curadora Sofia Victorino e o artista Kader Attia; Stedelijk Museum, com os curadores Jelle Bouwhuis / Kerstin Winking e o artista Quinsy Gario; Royal College of Art, com o curador Paul Goodwin e o artista Leo Asemota.

A exposição Pasado Inquieto. Narrativas y Fantasmas de la Exposición Internacional de Arte en Solidariedad con Palestina, 1978, realizada entre fevereiro e junho de 2015, que visou reconstruir as narrativas e os rastros da exposição inaugurada em 1978, em Beirute, e destruída pelos bombardeios do exército israelense, em 1982. Pasado Inquieto buscou questionar a história das exposições e a historiografia da prática e da percepção artísticas, além de questionar a problemática da história oral, as armadilhas da memória, a história 
escrita frente à inexistência de arquivos sólidos e convincentes, bem como revisar a transcendência do compromisso político na década de setenta, especialmente em universos não considerados vanguardistas ou hegemônicos, e, portanto, raramente estudados nas narrativas históricas contemporâneas. 


\section{ANEXO D - MODIFICAÇÃO DA NARRATIVA SOBRE A HISTÓRIA DA ARTE NA GESTÃO BARTOMEU MARÍ: SEMINÁRIOS, CONFERÊNCIAS, CURSOS E MESAS REDONDAS}

Mesa redonda La Historización de los Setenta, realizada em março de 2012, a propósito da exposição Centre Internacional de Fotografia Barcelona (1978-1983), que propôs repassar e questionar alguns dos tópicos dominantes e recorrentes na historicização do período da Transição Espanhola, como a centralidade da revista Nueva Lente, a naturalização de um discurso sobre a incorporação da fotografia no sistema artístico, o relato sobre a ruptura geracional dos setenta e o novo protagonismo da "quinta geração", tópicos explicativos do período, que, porém, geram suas próprias exclusões e pontos cegos que deveriam ser expostos e explorados. Contou com a participação de Enric Mira, Marie-Loup Sougez, Carmelo Vega e foi moderada por Jorge Ribalta e Cristina Zelich, curadores da exposição.

Ciclo de Seminários Las Derivas de la Teoria. La Periodización del Arte Contemporáneo, ministrado por Peter Osborne em abril de 2012, que pretendeu avaliar a vigência dos conceitos, problemáticas, antagonismos e debates que marcaram a década de oitenta e apontar possíveis vias de renovação, em um momento em que as posturas que outrora pareceram radicais, passaram a encontrar-se comodamente instaladas nos âmbitos acadêmicos.

Curso El Descontento y la Promesa. Colonialidad. Modernidad y Epistemologías Descoloniales, ministrado por Walter Mignolo em junho de 2014, que partiu de uma releitura crítica da história da modernidade realizada pelo autor, de que que a narrativa civilizatória do Iluminismo não foi o Humanismo, mas sim a colonização. Assim, num contexto de projetos de descolonização, que apostam na desconstrução da razão racial e patriarcal e sua lógica diferencial de progresso, o curso procurou levantar algumas questões: que lugar ocupam as instituições culturais na narrativa da modernidade colonial? O museu pode ser um lugar de descolonização do conhecimento e da sensibilidade ou segue sendo, na atualidade, um espaço de regulação e controle da produção de significado e de subjetividade?

Descolonizar el Museo, encontro coordenado por Paul B. Preciado, em novembro de 2014, para o qual foram convidados uma série de críticos, artistas, curadores e ativistas com o objetivo de explorar as linguagens e práticas de descolonização que colocam em questão as narrativas e representações imperiais e eurocêntricas que fundaram o museu do século XIX e 
XX. Foram explorados temas como Descolonizar la Historia, El Conocimiento, El Deseo, e Práticas, Activismos y Redes Descoloniales. Paralelamente ao encontro, foram realizadas atividades como B.D. Women: de la herida colonial a la disidencia sexual, projeto de investigação-ação que objetivou a ampliação e ativação de um arquivo de linguagens poéticopolíticas produzidas entre os anos oitenta e noventa pelas "diásporas críticas": uma multitude de vozes que contesta os novos regimes de racialização e sexualização intensificados na era neoliberal, além da atividade Barcelona (des)colonial. Posesiones de Ultramar y Cambio Urbano (1835-1898), realizado junto ao projeto Ruta de Autor, que consistiu num itinerário que pretendeu investigar sobre o investimento do capital gerado a partir da exploração das colônias na América na transformação da cidade de Barcelona.

Exposição Museo de Narrativas Paralelas - En el Marco de la Internacional, que disse respeito à necessidade por parte do MACBA, destacada por Bartomeu Marí, de abordar a produção artística da Europa Oriental. Nesse sentido, a exposição, realizada de maio a outubro de 2011, reuniu mais de uma centena de obras de cerca de setenta artistas que traçavam um panorama da arte de vanguarda dos países da Europa do Leste, desde 1961 até a atualidade. A maioria das peças formava parte da Coleção Arteast 2000+ da Galeria Moderna de Ljubljana, sendo que também foram apresentados sete projetos específicos para a exposição, sendo quatro sobre auto-historização e a criação de arquivos paralelos (realizados por Artpool, Július Koller, Zofia Kulik e Lia Perjovschi), e três sobre microcoleções fictícias, nas quais se estabeleciam conexões entre artistas ocidentais e orientais (apresentados por Alexander Dorner, IRWIN e Mladen Stilinović) (MACBA, online). Com o mesmo objetivo, vale comentar a respeito da exposição Series militares. Aleksandr Sokurov en la Colección $M A C B A$, que abordou a filmografia do cineasta russo, considerada imprescindível para o entendimento da complexidade que encerra a história da Rússia pós-soviética. 


\section{ANEXo E - ATIVIdAdes ORganizadas PELO PEI DURANTE A GeStão BARTOMEU MARÍ}

Seminário Subalternidad y Representación, realizado em outubro de 2008, que partiu dos estudos realizados pelo Grupo de Estudos Subalternos, a partir dos anos oitenta, que enfatizaram as geopolíticas coloniais, trabalhadas por intelectuais como Ranajit Guha, Dipesh Chakravarty, Homi Bhabha, Gayatri Spivak, Walter Mignolo, entre outros, e que procuraram como produzir uma historiografia contra-hegemônica, diferente da versão dos vencedores e/ou colonizadores. Nesse sentido, o seminário buscou explorar questões como: é possível pensar um novo ativismo artístico e cultural que articule de forma politicamente eficaz a relação entre práticas subalternas contra-hegemônicas e espaços críticos de produção de conhecimento, no museu, no mundo acadêmico e nos novos meios de comunicação em rede? Como produzir uma política da estética que não derive na mera constatação da realidade factual nem no fortalecimento das instituições de dominação existentes? De que modo pensar o potencial político dos grupos ou culturas subalternas, no marco da prática pós-colonial e do reconhecimento de novas categorias como "a multidão" ou "o anônimo"? Como reinventar e repolitizar as práticas artísticas e culturais frente às novas formas de exclusão da sociedade do espetáculo e da indústria cultural?

Ciclo El arte después de los feminismos, oficina monográfica organizada pelo PEI em 2009, que objetivou constituir um espaço de documentação, análise e reflexão em torno das implicações das recentes teorias feministas e queer no âmbito das práticas artísticas, e que contou com diversos seminários, como Donde Estuvo (o se Extravió) Lo Político; Micropoliticas Transmaricabolleras. Activismos Torcidos Antes y Después del SIDA, e Absorción y Resistencia: Retóricas identitarias y Marcos de Visibilidad.

Sick 80s/ Malditos Ochenta. Crisis del SIDA, Arte y Guerrilla Contrabiopolítica Seminário realizado entre outubro de novembro de 2010, organizado por Paul B. Preciado, para o qual foram convidados teóricos, ativistas e artistas, que objetivaram realizar uma arqueologia das linguagens, representações e práticas que emergiram durante a crise de AIDS nos anos oitenta. Foram também explorados temas como a pertinência da noção de biopolítica para caracterizar as formas contemporâneas de controle do corpo e da sexualidade, o uso da performance de gênero como estratégia política, a reapropriação da publicidade, dos meios de 
comunicação e das técnicas de marketing próprias do capitalismo tardio como estratégias de protesto e resistência à norma, entre outros, de modo a realizar um debate acerca da gestão contemporânea dos corpos soropositivos e da relação entre arte e ativismo como técnicas de redefinição da vida para além da biopolítica.

Seminário Musée d'Art Ancien, Département d'Art Moderne. Cómo Repensar las Organizaciones Culturales ante las Nuevas Relaciones entre Arte y Economía?, realizado em junho de 2008, dirigido por George Yúdice e com a participação de Maurizio Lazzarato, Ana Carla Fonseca Reis, Gerardo Mosquera e Stephen Wright, e que pretendeu refletir acerca da nova etapa do desenvolvimento capitalista, analisando sua incidência na privatização da cultura nas indústrias culturais e criativas, sua penetração na revitalização urbana, no trabalho e nas empresas, a propriedade intelectual e a arte, além de examinar como esta economia cultural incide sobre o público e de que maneira atua em relação ao conceito de serviço público

(MACBA, online).

Seminário Los Nuevos Productivismos, realizado em março de 2009, que partiu do tema da arte soviética revolucionária produzida entre as décadas de 1910 e 1930, buscando uma leitura crítica e a desconstrução de certos estereótipos que o acompanham, e levantando questões como: de que maneira a onda expansiva desse acontecimento reverbera na atualidade? Sob quais formas seria possível apropriar-se de alguns de seus procedimentos, modelos e ferramentas?

Seminário Sujetos Visibles/Historias Visuales. Los Relatos Femenistas, Queer y Trans Frente la Historiografia del Arte, realizado em maio de 2009, moderado por Paul B. Preciado, e com a participação de Marina Grzinic, Catherine Lord, Richard Meyer, Juan Antonio Suárez, Frank Wagner e Tim Stüttgen, que pretendeu refletir sobre as releituras realizadas sobre a historiografia, com relação a temas como arte, feminismo e micropolíticas sexuais, de modo a levantar questões tais quais: como entender a repentina inscrição institucional desses temas? Trata-se de uma recuperação despolitizadora ou da ocasião de repolitizar as narrações hegemônicas da arte? Como se restabelecem nessas novas narrativas figuras como Warhol, centrais ao projeto historiográfico dominante? Quais são as relações entre visualidade, representação pública, identidade, poder e subjetivação que delineiam essas historiografias subalternas? 
Seminário Conceptualismos del Sur, realizado em novembro de 2012, dirigido por Paul B. Preciado, com a participação de Aimar Arriola, Alex Brahim, Max Jorge Hinderer Cruz, R. Marcos Mota, Alicia Navarro, Fernanda Nogueira, Miguel A. López e Marc Siegel, que objetivou questionar a historiografia feminista, gay, lésbica e queer anglo-saxã, seus conceitos centrais e suas temporalidades, confrontando-a com a produção micropolítica do sul e dos contextos ditatoriais, pós-ditatoriais e pós-coloniais, desde a América Latina até a Espanha. Também pretendeu dar conta da passagem das estéticas camp e das políticas queer para uma multiplicidade de práticas de dissidência de gênero e de guerrilha sexual descolonizadoras e pós-identitárias que põem em questão as técnicas hegemônicas de produção da diferença sexual e suas instituições de reprodução cultural. 


\section{ANEXO F - GESTÃO BARTOMEU MARÍ: EXPOSIÇÕES MONOGRÁFICAS}

A exposição Disidanzas, entre julho e setembro de 2008, retrospectiva da obra da artista estadunidense Nancy Spero, pioneira da arte combativa dos anos sessenta e setenta, cujos trabalhos entrelaçam-se com temas e linguagens como feminismo, ativismo político, dança, figuração e poesia e se articulam com discursos dissidentes que abrem grandes brechas nos modelos patriarcais da modernidade então imperante.

A exposição $D a$ Capo, retrospectiva da obra do artista catalão Francesc Torres, pioneiro da linguagem de instalação, e que reflete criticamente sobre as diversas manifestações da cultura, da política, da memória e do poder por meio de suas instalações multimídia, que o concedem um lugar singular na arte das últimas décadas. A exposição, realizada de junho a setembro de 2008, incluiu uma seleção de trabalhos realizados desde o final dos anos sessenta até a atualidade, com obras de produção recente. Ainda, a mostra abarcou aspectos inéditos ou pouco conhecidos de seu trabalho, como por exemplo, a influência da prática poética em sua obra, além da importância do desenho e do trabalho sobre a imagem que vincula Torres com a linguagem da pintura.

A exposição Cildo Meireles, em cartaz entre fevereiro e abril de 2009, propôs um percurso pela obra do artista brasileiro através de suas grandes instalações, desenhos e objetos realizados entre 1967 e 2008 . A figura do artista é considerada fundamental para entender a vanguarda artística brasileira do pós-guerra, já que supõe uma ponte entre o neoconcretismo do final dos anos cinquenta e a arte conceitual brasileira do final dos setenta.

A exposição La Pasión Segundo Carol Rama, em cartaz no MACBA entre outubro de 2014 e fevereiro de 2015 buscou questionar os relatos dominantes da historiografia da arte por meio da exibição de trabalhos que obrigam a desmantelar narrativas e desmantelar conceitos, dessa artista que foi esquecida tanto pela historiografia hegemônica como pelo relato feminista, e cuja produção se estende ao longo de sete décadas (1936-2006), constituindo um contra arquivo que permite reconstruir os movimentos de vanguarda do século $\mathrm{XX}$.

Pudemos observar também o destaque para exposições de artistas catalães, como nas exposições Joan Rabascall. Producción 1964-1982; En el Laberinto - Àngels Ribé 19691984; Lejos de los Árboles. Jacinto Esteva en la Colección MACBA; Motor de Modernidad- 
Grup R. Arquitectura, Arte y Diseño; Nitrato, de Xavier Ribas; Tàpies como Síntoma - Una modernidad Sin Correspondencia; bem como exposições que abordaram acontecimentos importantes no contexto espanhol, da região e da cidade de Barcelona, como La Utopía es posible. ICSID. Eivissa, 1971, sobre o VII Congreso do International Council of Societies of Industrial Design (ICSID) que aconteceu em Ibiza, em 1971, concebido como um ponto de confluência entre o design e as formas mais experimentais da arte e da arquitectura da época no país; e Le Corbusier y Jean Genet en el Raval, que abordou as experiências do arquiteto e do escritor, respectivamente, no bairro em que o MACBA está localizado. 


\section{ANEXO G - GESTÃO FERRAN BARENBLIT: EXPOSIÇÕES MONOGRÁFICAS}

Exposição José Antonio Hernández-Díez. No Temeré Mal Alguno, realizada entre março e junho de 2016, no espaço do Convento dels Àngels, em que foram apresentadas obras do artista venezuelano José Antonio Hernández-Díez, que cultivava a ideia da arte contemporânea como uma linguagem global, e procurou questionar o domínio dos artistas europeus e norteamericanos. Participaram de No temeré mal alguno obras do final dos anos oitenta e início dos noventa, bem como um novo projeto desenvolvido especificamente para a exposição. Trata-se de trabalhos experimentais em vídeo, junto com outras obras realizadas com suporte de telas e vitrines.

Exposição Punk. Sus Rastros en el Arte Contemporáneo, realizada entre maio e setembro de 2016, em coprodução com o CA2M, de Madrid, ARTIUM, Centro Vasco de Arte Contemporáneo, em Vitoria, e o Museo Universitario del Chopo, na Cidade do México. Com curadoria de David G. Torres, a exposição consistiu em um percurso através da influência do punk sobre a arte atual, destacando a importância de sua presença como atitude e referência para muitos criadores. Compreendeu instalações, documentos, múltiplos, fotografias, vídeos e pinturas, além de uma seção documental sobre as orgens do punk e seus vestígios na atualidade. Algumas das temáticas abordadas foram o ruído, a negação, a violência, o nihilismo e a sexualidade. Também a instatisfação, o inconformismo, a perda de fé no progresso e a crítica feroz aos ícones do sistema econômico e social aparecem na obra dos artistas participantes. Punk foi a única adição de Ferran Barenblit ao programa já definido para 2016, sendo que o tema foi abordado por ele também no CA2M. Para o diretor, não se tratava de uma exposição sobre o punk, nem se pretendia contruir uma genealogia sobre o movimento. Desse modo, na exposição, o punk aparece como referência explícita em muitos artistas, como no uso de elementos como ruído, a tipografia de recortes, o antidesenho e o "feísmo", bem como por meio da referência à grupos musicais. Por outro lado, mostra-se as influências do punk como atitude: a oposição, a destruição, o "faça você mesmo", a alusão ao medo e o terror em uma sociedade que aliena o indivíduo, a crítica ao sistema econômico e a anarquia, e a reivindicação da liberdade sexual e do corpo como lugar de batalha.

Exposição Andrea Fraser. L'1\%, C'est Moi, realizada no MACBA entre abril e outubro de 2016 e produzida junto ao Museu Universitário de Arte Contemporáneo, 
localizado na Cidade do México. L'1\%, c'est moi foi a primeira exposição monográfica de Andrea Fraser na Espanha. Sua obra examina as motivações de um amplo leque de agentes culturais, além de estar vinculada à crítica institucional, e influenciada pelo feminismo, a psicanálise e a teoria dos campos sociais do sociólogo Pierre Bordieu, de modo que constitui uma análise penetrante do tecido social do mundo da arte. A exposição reuniu uma seleção de obras realizadas ao longo de mais de trinta anos de práticas críticas, desde obras iniciais em papel, baseadas na apropriação, visitas guiadas e performances de vozes múltiplas, até instalações, trabalhos de base textual e documentação.

Exposição Miralda MADEINUSA realizada entre outubro de 2016 e abril de 2017, que buscou recuperar a totalidade dos projetos do artista espanhol Antoni Miralda relacionados a sua estadia nos Estados Unidos. Sob curadoria de Vicent Todolí, Miralda MADEINUSA documentou, pela primeira vez, em colaboração com o artista e seu arquivo, os 14 projetos realizados nos Estados Unidos, desde meados dos anos sesseta até o final dos noventa. Foram reconstruídas as instalações mais significativas e apresentadas esculturas, desenhos, fotografias, audiovisuais, esboços e outros materiais que permitiram ilustrar o alcance e a complexidade dos projetos e dimensionar a vontade coletiva que caracteriza a metodologia do artista, centrada na participação, na ideia de ritualidade ou cerimônia, e na gastronomia.

Exposição Gelatina Dura - Historias Escamoteadas de los 80: ao final dos anos oitenta, era divulgada pela imprensa espanhola um trânsito supostamente pacífico e gradual do regime ditatorial franquista a uma monarquia parlamentária, conduzida por políticos do sistema anterior. O relato oficial dos anos oitenta no país teria advogado pela instauração da democracia, que priorizou a necessidade sobre a razão, e consolidou uma perspectiva que privilegiou o futuro, ao invés de uma análise do passado e a crítica à filiação do novo sistema com resquícios do poder franquista. Nesse contexto, a cultura foi utilizada pelos partidos políticos como forma de mediação de grande potencial, e promovida como ato celebratório, festivo, de forma instrumentalizada. Diante disso, a exposição comissariada por Teresa Granadas, realizada entre novembro de 2016 e março de 2017, pretendeu abordar o período entre 1977 e 1992, de modo a evidenciar histórias ignoradas pelos relatos oficiais do período, abordando a cultura underground dos setenta, que se manifestava em meio à clandestinidade e à censura, e que, nos oitenta, passa a ditar a reformulação crítica das próprias práticas 
culturais. Assim, por meio de publicações, revistas, comics, exercícios antiartísticos, etc. essas práticas deram tom ácido a imagens de regeneração democrática do país, questionando a vontade dos partidos políticos de esquecer o período da ditadura e os anos que a seguiram, sem o necessário processo de análise das responsabilidades políticas e consequências sociais.

Muestreo \#1 - Los Documentos a Escena: exposição realizada, entre abril e setembro de 2017, no espaço térreo do CEDOC, que apresentou um conjunto de materiais advindos das coleções e fundos documentais do Arquivo MACBA, no que pretendeu ser um exercício cotidiano de abertura de conteúdos que habitualmente permanecem velados sob as condições de conservação e acesso próprias do tratamento arquivístico. Nesse sentido, a mostra consistiu em uma seleção de documentos relacionados com práticas transdisciplinares e efêmeras em torno da performance, no contexto da arte contemporânea, de modo a apontar uma série de reflexões necessárias acerca da relação entre a performance e o arquivo e suas aparentes contradições. Assim, na revisão desse material, evidenciou-se a dificuldade de se documentar uma obra efêmera que passa, em muitas ocasiões, pelo corpo. Trata-se, pois, de um tipo de obras de caráter "perecível”, que tem suas origens em movimentos de vanguarda como a arte conceitual do final dos anos sessenta, e que partem de um distanciamento das lógicas do mercado de arte e das práticas institucionais como reivindicação política e/ou declaração de autonomia.

Akram Zaatari - Contra La Fotografía. Historia Anotada De La Arab Image Foundation: exposição realizada entre abril e setembro de 2017, a partir do arquivo da Arab Image Foundation (AIF), em Beirute, no Líbano, que contém material fotográfico proveniente do Oriente Médio, Norte da África e da diáspora árabe, e foi criada por artistas preocupados com a preservação fotográfica, a fim de atuar como um centro dedicado ao estudo da fotografia e às práticas de colecionismo, preservação e divulgação de imagens. Para além de mostrar um amplo espectro de representações visuais do mundo árabe, os artistas que constituíram a coleção abordaram questões radicais referidas aos documentos fotográficos e sua função na atualidade, de modo que comportam a escritura de histórias sobre a vida cotidiana e pequenos eventos e acontecimentos sociais em general, e geraram novos discursos com relação ao meio. Ainda, longe de oferecer um relato histórico da AIF, a exposição pretendeu apresentar a perspectiva de um de seus artistas fundadores, Akram Zaatari. Desse modo, o trabalho do artista sobre fotografia e colecionismo adota uma perspectiva 
arqueológica, que escava o passado para fazer aflorar novas narrativas, ressituando-as na contemporaneidade. A exposição foi realizada pelo MACBA junto ao Museu Nacional de Arte Moderna e Contemporânea da Coreia, sob curadoria de Bartomeu Marí e Hiuwai Chu.

Muestreo \#2. This is Mail Art, exposição realizada no piso térreo do CEDOC, entre outubro de 2017 e janeiro de 2018, que agrupou uma série de contéudos do Arquivo MACBA vinculados a práticas artísticas que utilizaram o envio por correio como sistema de distribuição. Trata-se de criações de artistas para artistas, concebidas como intercâmbios isentos de valor comercial e distribuídas à margem dos circuitos institucionais através de redes colaborativas internacionais. Os envelopes, postais e selos são utilizados como suportes criativos junto com fotocópias, gravuras e colagens que jogam não apenas com a linguagem e a estética próprias do correio oficinal, mas também com as lógicas de comunicação desse sistema. Tanto formal como conceitualmente, mantêm vínculos com o dadaísmo, o Fluxus e a poesia experimental. Entre o absurdo e o ativismo, essas práticas se desenvolveram com maior intensidade no contexto de regimes políticos opressores, com especial relevância na América Latina. Foi comissariada por Maite Muñoz.

Poesía Brossa, retrospectiva do trabalho do artista catalão através de seus livros e investigações plásticas, que atravessam a poesia, o teatro, o cinema, a música e as artes de ação. Joan Brossa (Barcelona, 1919/98), desenvolveu sua prática artística desde os anos quarenta, em um contexto sociopolítico marcado pela ditadura franquista e em uma situação cultural caracterizada pela ausência de propostas vanguardistas e inovadoras. Desde o início de sua produção, Brossa desenvolve un trabalho de renovação estética fundamentado na investigação literária e artística. Até o momento de sua morte, sua extensa produção não deixa de buscar novas formas de expressão e de experimentar com os diferentes meios. A exposição comissariada por Teresa Grandas e Pedro G. Romero, em cartaz entre setembro de 2017 e fevereiro de 2018, pretendeu também revisar as constelações de artistas em torno a Brossa, as interrelações com trabalhos que permitem estabelecer numerosos paralelismos, buscar diálogos e tensões, e enfatizar os aspectos performativos de sua prática poética.

The Maids. II Premio Fundación Han Nefkens-MACBA, exposição proposta pelo coletivo iraniano de artistas formado por Ramin Haerizadeh (Teherán, 1975), Rokni Haerizadeh (Teherán, 1978) e Hesam Rahmanian (Knoxville, 1980), estabelecidos em Dubai, 
que recebeu o II Prêmio Fundación Han Nefkens - MACBA de Arte Contemporáneo. Realizada entre outubro de 2017 e janeiro de 2018, tratou-se de uma exposição participativa criada como resposta à cidade de Barcelona, resultado de um processo de dois anos que os artistas definiram como a montagem de um corpo coletivo. Assim, a colaboração constituiu um aspecto central da exposição, que teve como objetivo gerar formas mais equitativas de intercâmbio artístico, de modo que foram convidados diversos criadores a contribuir, com liberdade e independência, para as obras em curso. Foram convidados a participar do projeto Joan Baixas, conhecido criador de teatro de marionetes e diretor cênico catalão; a artista Niyaz Azadikhah, que dirigiu oficinas de costura comunitárias para mulheres en Teherán; John Cole, engenheiro robótico especializado em sensores, e um grupo internacional de escritores, entre os quais Mandana Mohit e Sohrab Mahdavi, de modo que The Maids mostrou o resultado dessas colaborações.

Rosemarie Castoro. Enfocar al Infinito, retrospectiva acerca da obra de Rosemarie Castoro, centrada no período entre 1964 e 1979. Castoro se iniciou como artista nos Estados Unidos em um momento em que o minimalismo e o conceitualismo formavam parte da vaguarda nova-iorquina. Enfocar al Infinito, comissariada por Tanya Barson e realizada entre novembro de 2017 e abril de 2018, buscou mostrar a obra da artista em detalhe pela primeira vez, revelando assim a diversidade de uma prática artística que inclui pintura abstrata, arte conceitual, ações performativas nas ruas e no estúdio, poesia, mail art, escultura, intalações e land art. Foi analisado também o contexto de seu trabalho, seu ativismo na Art Workers' Coalition, sua associação com artistas contemporâneos como Carl Andre, Hollis Frampton, Sol LeWitt e Yvonne Rainer, entre otros, e sua relação com o feminismo. Buscou-se assim evidenciar as grandes contribuições de Castoro ao conceito de intermedia, a interrelação entre pintura, escultura, desenho, linguagem e performance. A intenção foi demonstrar como algumas das figuras mais relevantes do minimalismo não receberam a atenção que merecem, especialmente o grupo de mulheres artistas pertenecentes a um movimento erroneamente identificado como essencialmente masculino. Como consecquência, a exposição assinalou a necessidade de se repensar o minimalismo, expandindo-o para incluir um maior número de artistas e a fim de questionar os relatos hegemônicos do movimento. 


\section{ANEXO H - DEBATE POLÍTICO NA GESTÃO FERRAN BARENBLIT: EXPOSIÇÕES, SEMINÁRIOS, CONFERÊNCIAS, CURSOS E MESAS REDONDAS}

Forensic Architecture - Hacia Una Estética Investigativa, exposição sobre os trabalhos do grupo de pesquisadores baseado em Londres Forensic Architecture, coproduzida junto ao MUAC, e realizada entre abril e outubro de 2017. Suas pesquisas revolvem em torno de violações dos direitos humanos em escala global, de modo que apresentam provas evidentes aos tribunais internacionais, colaborando com grupos ativistas, organizações como a Anistia Internacional e as Nações Unidas. O grupo foi responsável pela criação de uma nova modalidade de prática investigativa que leva o nome do grupo, a arquitetura forense. Assim, seus integrantes utilizam a arquitetura como ferramenta metodológica para investigar conflitos armados e a destruição do meio ambiente, bem como para complementar e cotejar, por meio de outras fontes probatórias, os sensores remotos, as investigações materiais e os testemunhos presenciais. A exposição buscou então apresentar tal prática, sublinhando suas origens, sua história e seus êxitos, bem como dificuldades e limitações. Consistiu em investigações, acompanhadas de textos críticos, nos quais o grupo examinou como se produz -tecnológica, arquitetônica e esteticamente - a verdade pública, como confrontar a propaganda e os segredos de Estado, e como denunciar novas formas de violência estatal

Colección MACBA. Martha Rosler: God Bless America!, exposição realizada entre maio e outubro de 2017 centrada sobre a produção videográfica de Matha Rosler, através de onze obras realizadas desde os anos setenta até 2006. Como sabemos, a obra da artista tem examinado, ao longo de quase cinquenta anos, os mecanismos da cultura contemporânea sob uma perspectiva crítica e feminista. As obras selecionadas trataram de temas como imigração, exploração laboral, a cumplicidade entre as corporações multinacionais, o governo dos Estados Unidos e os regimes ditatoriais da América Latina, e as transgressões da vida privada cometidas pelo poder do Estado. Um segundo grupo de vídeos abordou análises de gênero, nos quais a artista explorou a esfera doméstica e a instrumentalização do corpo feminino por parte dos meios de comunicação, a indústria da moda e da publicidade, assim como nos âmbitos legal, médico e científico.

In The Same Boat, conversa realizada em fevereiro de 2016, acerca dos temas levantados pelo documentário homônimo, com o diretor Rudy Gnutti, o produtor Pere 
Portabella e o sociólogo e filósofo Zygmunt Bauman, que participa do documentário, que revolve em torno da seguinte questão: Por que, se hoje detemos os mecanismos para melhorar e racionalizar a vida em nosso planeta, parecemos estar fadados a um desastroso e previsto colapso?

Procesos Constituyentes. Hacia una Nueva Democracia en Europa - Materiales para la Discusión desde Latinoamérica y el Espacio Político Europeo, encontro organizado pelo MACBA em março de 2016, junto à Hidra Cooperativa e à Fundación de los Comunes, que objetivou contribuir com experiências e reflexões a partir dos processos constituintes latinoamericanos das últimas décadas, em particular Equador e Bolívia. No primeiro encontro, foi abordado como, nesses países, foram redigidas novas constituições que conseguiram plasmar reivindicações sociais dos movimentos de base graças à acumulação de décadas de mobilizações. São textos que reuniram inovações políticas tais como a plurinacionalidade ou novos regimes de propriedade baseados em bens comuns. Entretanto, as convulsões políticas dos últimos tempos põem em questão algumas das conquistas dessas revoluções democráticas. Pretendeu-se abordar também a necessidade de se manter um poder constituinte sempre vivo, capaz de manter a oportunidade aberta e impulsionar os processos políticos para além de seus limites institucionais. No segundo encontro, tratou-se da necessidade de um processo constituinte na União Europeia e da rigidez que o euro impõe às economias deficitárias, frente às que têm superávit, o que tem provocado tensão política entre os Estados Nações europeus desde o fim da Segunda Guerra Mundial (MACBA, online).

\section{Máquinas Constituyentes: Poder Constituyente, Biopolítica, Democracia,} conferências realizadas, em abril de 2016, dentro do programa Máquinas constituyentes: poder constituyente, biopolitica, democracia, organizado pelo MACBA junto ao Centro de Estudos do Museu Reina Sofía, ministradas pelo sociólogo Wolfgang Streeck. O objetivo das sessões foi compreender a situação de múltipla cirse institucional na qual se encontra o projeto da União Europeia e sua retroalimentação pela crise sistêmica do capitalismo e as bifurcações enfrentadas pela economia global. Também pretendeu-se estudar os diversos cenários nos quais o projeto europeu poderia aventurar-se para poder sair desse impasse, debater as iniciativas políticas que deveriam acometer-se para idealizar um curso pragmático de ação política eficaz para introduzir uma nova ordem política e constitucional, além de analisar as características das forças políticas que estariam em condições de desempenhar tais tarefas (MACBA, online). 
Los Ochenta a Contrapelo, seminário internacional realizado em dezembro de 2016, que propõs uma revisão do passado recente da Europa, em especial a década de oitenta, mediante a abordagem de temas como a espiral crescente de desigualdade, a desindustrialização, as grandes regiões empobrecidas, os desequilíbrios Norte-Sul, a instrumentalização da cultura e o e crescente fantasma do fascismo que assombra a Europa. No caso espanhol, partiu-se da necessidade de se revisar o relato oficial dos anos oitenta, uma era marcada pelo entusiasmo, a internacionalização da indústria, da arte e da cultura, o desenvolvimento urbanístico e de infraestructuras, que na realidade ocultava uma financeirização acelerada, uma desindustrialização a serviço dos tratados de Maastricht e um processo de apagamento da memória. Nesse sentido, o seminário apontou algumas das linhas que o MACBA já vinha explorando em projetos anteriores como Desacuerdos, e que pretende seguir explorando. Foi dividido em três blocos temáticos: Movilización global y desregulación: los cimientos de la gubernamentalidad neoliberal, Sexualidades disidentes e Relatos de la contracultura (MACBA, online).

Barcelona Wars: Del Imperio de los Rentistas al Contra Ataque Vecinal, curso realizado entre dezembro de 2016 e janeiro de 2017, que tratou da desenfreada atuação da especulação, em Barcelona, sobre o aumento dos custos de habitação. Pretendeu atuar como espaço para a criação de ferramentas de contruibuição para a luta contra tal fenômeno, começando por recuperar os processos que geraram esse cenário, bem como as estratégias de luta realizadas nos bairros e como potencializá-las, de modo a visualizar formas de resistência organizadas.

Crisis Global y Teoría Urbana Crítica, seminário realizado em março de 2017, que propôs abordar debates centrais da teoria urbana na atualidade: a expansão da urbanização, a dialética multiescalar centro-periferia e a emergência de movimentos sociais urbanos, além de questionar, quando necessário, o papel da hegemonia teórica angloamericana na definição dos grandes temas de reflexão. Organizado pelo grupo de pesquisa transdiciplinar Espais Crítics, em colaboração com a Agència de Gestió d'Ajuts Universitaris i de Recerca; Universitat de Barcelona; Universitat Autònoma de Barcelona; Universitat Oberta de Catalunya e Icaria Editorial. 
Economía y Ecología Política Del Turismo, curso realizado entre março e abril de 2017, que pretendeu fortalecer a análise crítica do turismo a partir das perspectivas da economia e da ecologia política, de modo a formar um espaço de debate comprometido com as necessidades e direitos dos cidadãos sobre seu território e seus recursos.

Poner a las Mujeres en el Centro para Pensar el Presente. Violencia, Comunidad y Estado en el Siglo XXI, encontro com a ativista e professora do Centro de Estudios Andinos y Mesoamericanos (CEAM), na Cidade do México, e do Instituto de Ciencias Sociales y Humanidades de la Universidad de Puebla (ICSYH-BUAP), Raquel Gutierrez, realizado em março de 2017, em que se propôs pensar o mundo desde a perspectiva das mulheres, seu posicionamento determinado nas sociedades e a forma como se vêem afetadas pelas políticas públicas e de mercado e por meio das seguintes questões: o que nos diz do mundo a atroz violência que na atualidade profana o corpo das mulheres em tantos lugares? O que nos diz do mundo o fato de as necessidades de reprodução coletiva serem sempre postergadas? Quais são os problemas centrais nos processos de autonomia social? $O$ que são as tramas comunitárias? É possível transformar as instituições desde a racionalidade do Estado? Que vínculos existem entre os governos progressistas e a lógica masculina?

La Revolución Jurídica de los Bienes Comunes, curso realizado entre abril e maio de 2017, que teve como principal objetivo compartilhar estratégias políticas e ferramentas jurídicas para defender os bens comuns. Partiu-se do entendimenro que, sem a aliança entre espaços de luta e saberes de especialistas em direito administrativo, é difícil poder intervir nos marcos jurídicos vigentes. Desse modo, o curso buscou oferecer algumas ideias e conexões para consolidar essa aliança. Partiu-se da noção de que a reapropriação dos bens comuns deve ser abordada como problema institucional, de modo que se ressalta a necessidade de defender, desenhar, implementar e assumir um conjunto de direitos, normas, obrigações e compromissos para reapropriar-se do que foi alienado e garantir as condições materiais de subsistência e reprodução social. Sendo assim, tornam-se necessárias não apenas a adoção deoutras métricas, mas também a exigência de marcos jurídicos que revertam a situação.

La Pesadilla que no Acaba Nunca - Conversación entre Marina Garcés y Christian Laval: A propósito da publicação em castelhano do ensaio La pesadilla que no acaba nunca, de Pierre Dardot e Christian Laval, a filósofa Marina Garcés conversou com Laval acerca das 
tensões às quais o projeto neoliberal submete a democracia e da necessidade de se propor projetos alternativos que situem a vida em seu centro, em um contexto em que o atual regime de radicalização da razão neoliberal impulsiona uma crise contínua das instituições tradicionais e o projeto europeu vacila, sendo incapaz de sustentar suas instituições e sua legitimidade ante sua inoperância para freiar os movimentos xenófobos que atravessam o continente. Conversa realizada em junho de 2017.

Las Imágenes Recurrentes. Sobre las Condiciones Materiales de su Retorno. Jornadas sobre Visualidades Críticas, realizadas em setembro de 2017, divididas em três sessões, e que reuniram falas e manifestações de diversos artistas, como Cuerpos, espectros y formas de vida, apresentada pela professora de História da Arte Contemporânea da Universidade Complutense de Madrid, que tratou das possibilidades de uma narrativa visual bio-histórica como forma de escritura viva, além da leitura coletiva com os artistas e cineastas Silvia Maglioni e Graeme Thomson a respeito do trabalho Dark Matter Cinema Tarot, que constitui uma tecnologia vernácula, uma ferramenta para explorar coletivamente de que modo as imagens podem abrir novos canais de infra-percepção que conectem as pesquisas com distintos âmbitos de experiência pessoal, estética, social e política, aproximando-se da matéria obscura que ronda a imagem cinematográfica.

365 Días de Trabajo Invisible, Mesa de debate realizada em dezembro de 2017 pela defesa dos direitos dos trabalhadores domésticos, de limpeza e de cuidados, organizada pela revistra Werker, pelo Office for Art, Design and Theory, de Utrecht, e Spector Books, a propósito do lançamento da publicação 365 Days of Invisible Work, da qual foram coeditores. 


\section{ANEXO I - PROJETO MUSEO CERRADO: PARTICIPANTES}

Salah Malouli, gestor cultural e tradutólogo que atuou em múltiplos festivais na Espanha e no Marrocos, tendo colaborado na organização de projetos culturais como $\mathrm{Bcn}$ Mp7 hip hop Casablanca; BAFF anime 2010; Festival Slam Klam e El Uno y el Múltiple, projeto de residências e exposições. Foi fundador da plataforma Opentaqafa, laboratório de investigação sobre a cultura livre no Marrocos, além de integrar o Arco Atlántico e de loLabs, rede de laboratórios de experimentação com tecnologias.

Coletivo Leland Palmer, que concebe a prática curatorial como um processo de investigação, e aposta pelo codesenvolvimento e a construção de espaços participativos a partir da interação, do intercâmbio de ferramentas críticas e de micronarrativas que ajudem a gerar um discurso crítico coletivo.

Jesús Palomino, artista espanhol que apresentou projetos recentes, vinculados à arte site-specific, trabalhando com a identidade do lugar. Seus interesses estéticos estiveram relacionados com os lugares, os espaços, as localizações e as comunidades nas quais foram realizados, de modo que tais projetos acabaram tomando uma orientação social. São instalações e propostas idealizadas para realizar um comentário ético e estético sobre temas como os direitos humanos, a ecologia, o diálogo cultural ou a crítica democrática.

O/A artista Hector Acuña/Frau Diamanda, que apresentou Arte Trans Peruano Portafolio Audiovisual, projeto pessoal que abordou práticas performativas invisibilizadas pelo sistema de arte peruano contemporâneo, e no qual foram explicitados trabalhos de Giuseppe Campuzano, Javi Vargas Sotomayor, Pedro Palanca, David Sánchez, Héctor Acuña/Frau Diamanda, Javier Temple, Carla Montalvo/Carlita Uchu e JC Bondage. Trata-se de trabalhos que se inscrevem dentro de uma nova historicidade "marika", que exige ser revisitada para revalorizar sua resistência e luta sociopolítica.

O coletivo argentino Etcétera de atividade multidisciplinar e integrado por artistas provenientes dos âmbitos da poesia, dos teatro, artes visuais e música, fundado com a intenção de aproximar a arte de lugares de conflito social - as ruas - e transferir esses 
conflitos aos espaços de produção cultural, incluindo os meios de comunicação e instituições de arte.

A rede Translocalia, formada por artistas, designers, curadores e profissionais de disciplinas diversas, com o intuito dec questionar o futuro através da arte. Trata-se de uma comunidade de profissionais, principalmente mulheres, que pretende desafiar o status quo, por meio de uma infraestrutura flexível, com a qual possa testar ideias e investigar contextos locais a fim de criar microprojetos artísticos e ações participativas. Entre outros projetos, o grupo tratou, no MACBA, da iniciativa PROJECT_16, proposta realizada em Lahore, São Paulo e Londres com projetos de artistas cujas práticas participativas se desenvolvem no espaço público e implicam seus usuários, tratando de tecer um novo sistema de relações através da arte.

CaldodeCultivo, coletivo transdisciplinar com base em Bogotá, que apresentou seus projetos recentes. Sua prática é centrada no questionamento das políticas neoliberais e as narrativas que as justificam, colocando em evidência as imposições, exclusões e violências que essas implicam. Assim, o grupo busca tratar de problemáticas de caráter global, como os processos de renovação urbana e os deslocamentos que geram, por meio de projetos artísticos que desenvolvam distintas estratégias artísticas para criar dispositivos de contrainformação, provocação e agitação popular que involucram as comunidades afetadas. 


\section{ANEXO J - ATIVIdAdes REAlizadAS PELO PEI DURANTE A Gestão FERRAN BARENBLIT}

Petróleo, seminário PEI Aberto realizado em maio de 2017, com o objetivo de atuar como espaço de aprendizagem, reflexão, debate e ação poética e política acerca da excepcionalidade de nosso tempo. Para tanto, o seminário pretendeu entrecruzar quatro rotas de exploração teórica e política: o diagnóstico preciso de nossa "extralimitação"; o debate sobre o futuro do crescimento econômico; a dissolução dos regimes políticos e de produção de subjetividades próprios do pósfordismo e o mapeamento de formas embrionárias que prefiguram relações ecossociais adaptadas a um mundo sem energia fóssil. O objetivo foi realizar um diagnóstico penetrante do que a crise civilizatória põe em jogo e redefinir as margens de ação política emancipatória como arte do possível.

A primeira sessão do seminário, denominada Límites Sobrepasados, contou com as apresentações: El ocaso del petróleo, por Emilio García Ladona, doutor em física e pesquisador do Instituto de Ciencias del Mar de Barcelona (CSIC), em temas relacionados à dinâmica da circulação oceânica; Límites minerales a la tercera revolución industrial, por Alicia Valero, engenheira química e pesquisadora do grupo de Ecologia Industrial no Instituto CIRCE e professora associada da área de Máquinas e Motores Térmicos da Universidade de Zaragoza; Una historia de la patología sociometabólica global vista desde los conflictos socioecológicos, por Leah Temper, acadêmica e ativista multidisciplinar, especializada em economia ecológica e ecologia política, fundadora e diretora do Global Atlas of Environmental Justice.

A segunda sessão, El problema del crecimiento, foi marcada pelas palestras: Las ocultadas causas políticas de la crisis, por Vicenç Navarro, catedrático de Ciências Políticas e Sociais na Universitat Pompeu Fabra, e professor de Políticas Públicas na Johns Hopkins University (Baltimore, EUA); La transición ecosocial ante el acantilado de Séneca, por Ugo Bardi, professor de química na Universidad de Florencia, onde se dedica à investigação sobre sustentabilidade e energia com uma visão especial sobre o esgotamento dos recursos minerais; La desposesión de la vida cotidiana, por Miren Etxezarreta, catedrática emérita de Economía Aplicada na UAB, além da mesa redonda El futuro del crecimiento económico, da qual participaram os três palestrantes. 
Na terceira sessão, Políticas y Sujetos Insostenibles, foram apresentados: El auge de los econacionalismos, por Razmig Keucheyan, professor de sociologia na Universidade de Burdeos, ativista da esquerda radical suíça e membro do Grupo de Estudos sobre Métodos de Análise Sociológicos da Sorbonne; Los feminismos ante la crisis socioecológica, por Yayo Herrero, antropóloga, educadora social e engenheira técnica agrícola; Reconstruir culturas, transformar identidades: sobre la necesidad de la conversión socioecológica, por Jorge Riechmann, ensaísta, poeta, e ativista de questões de ecologia social, além de professor de filosofia moral e política na Universidade Autônoma de Madrid.

Revolución, edição do seminário PEI Aberto que, a propósito do centenário da Revolução Russa (1917-2017), realizado em setembro de 2017, pretendeu retomar os modos como tal acontecimento condicionou de maneira decisiva o decurso da história social, política e cultural do último século, assim como a forma como contribuiu para ressignificar o próprio conceito de revolução, central na teoria política da modernidade. Assim, tendo a Revolução Russa como divisor de águas, o seminário pretendeu esclarecer acerca das relações entre a teoria e a história da revolução, a fim de interpelar, sob um novo ângulo, o presente. $\mathrm{O}$ seminário contou com a conferência Espectros centelleantes de octubre. Conceptualizar la revolución, ministrada por Enzo Traverso, professor de Humanidades da Universidade de Cornell, especializado em história intelectual do século XX, além de um colóquio moderado por Jaime Vindel, que pesquisa as interseções entre arte, ativismo e política desde os anos sessenta, até a atualidade.

Aprender a Imaginarse. Sobre Pedagogías y Emancipación, edição do seminário PEI Aberto realizado em novembro de 2017, e organizado pelo chefe de Programas Públicos Pablo Martínez, que pretendeu abordar o modo como os processos formativos podem chegar a ser espaços para a ativação de uma imaginação política que intervenha no âmbito do social e pensados como uma possibilidade de produção de formas de vida, sempre de maneira coletiva e interdependente. Para o debate, foram convocados distintos projetos e pensadores que, a partir de diversas práticas, podem alimentar modos de aprendizagem que permitam pensar e atuar de maneira radical sobre a realidade. O objetivo não foi tanto o de realizar um diagnóstico do estado da questão, mas sim exercitar o pensamento de outras educações possíveis, a fim de redefinir as margens da potência da educação. 
Participaram Marina Garcés, filósofa e professora na Universidade de Zaragoza, com a conferência Crítica y educación; valeria flores, com Activaciones poéticas de la disidencia. Un hiato pedagógico para criar una lengua emancipatoria; María Berríos, com El camino no es el camino. Acerca de la poética pedagógica de la Escuela de Valparaíso; o coletivo Microsillons que, desde 2012, desenvolve, em Genebra, uma pesquisa sobre a presença de Paulo Freire na cidade, durante a década de setenta; a coferência Entre utopía y desencanto. Una genealogía afectiva, por Sofia Olascoaga; Técnicas para vivir de otro modo. Lecciones de vida del poscapitalismo en los archivos de la educación emancipatoria, pela pesquisadora, educadora e curadora Janna Graham e a mesa redonda La educación como campo de batalla, com a participação de Concha Fernández Martorell, catedrática de Filosofia da Universidade de Barcelona e Jaume Carbonell, pedagogo, jornalista e sociólogo. 